Prepared in cooperation with the Geauga County Planning Commission and Board of Commissioners

\title{
Groundwater Quality in Geauga County, Ohio- Status, Including Detection Frequency of Methane in Water Wells, 2009, and Changes During 1978-2009
}
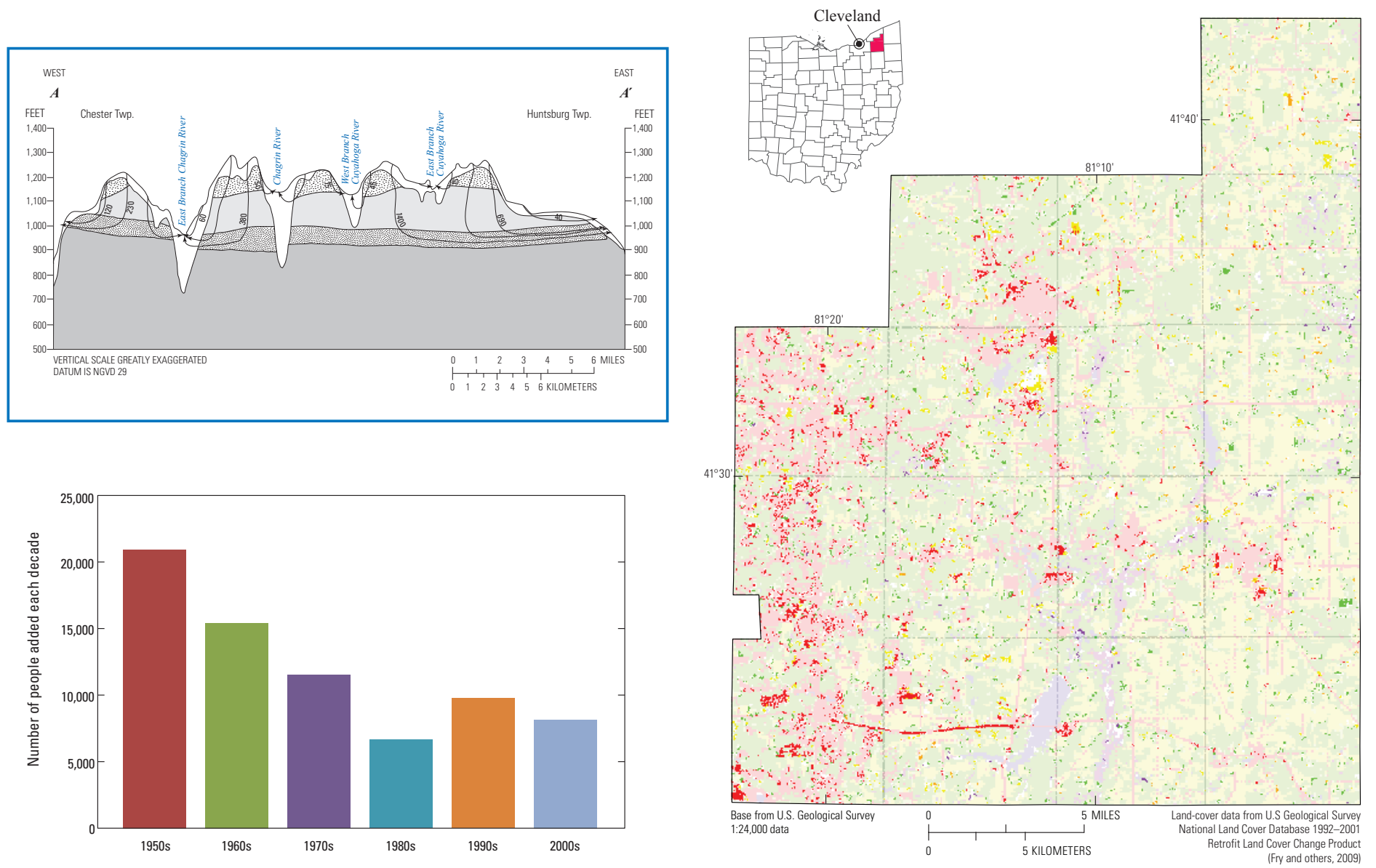

Scientific Investigations Report 2015-5032 
Front cover: Collection of figures from the report, including map of Geauga County, a cross section of the area, and sample graph of county population growth. For more details, see figures 2,4 and 6 . 


\section{Groundwater Quality in Geauga County, Ohio-Status, Including Detection Frequency of Methane in Water Wells, 2009, and Changes During 1978-2009}

By Martha L. Jagucki, Stephanie P. Kula, and Brian E. Mailot

Prepared in cooperation with the Geauga County Planning Commission and Board of Commissioners

Scientific Investigations Report 2015-5032 


\title{
U.S. Department of the Interior SALLY JEWELL, Secretary
}

\section{U.S. Geological Survey Suzette M. Kimball, Acting Director}

\author{
U.S. Geological Survey, Reston, Virginia: 2015
}

For more information on the USGS - the Federal source for science about the Earth, its natural and living resources, natural hazards, and the environment-visit http://www.usgs.gov or call 1-888-ASK-USGS.

For an overview of USGS information products, including maps, imagery, and publications, visit http://www.usgs.gov/pubprod/.

Any use of trade, firm, or product names is for descriptive purposes only and does not imply endorsement by the U.S. Government.

Although this information product, for the most part, is in the public domain, it also may contain copyrighted materials as noted in the text. Permission to reproduce copyrighted items must be secured from the copyright owner.

Suggested Suggested citation:

Jagucki, M.L., Kula, S.P., and Mailot, B.M., 2015, Groundwater quality in Geauga County, Ohio-Status, including detection frequency of methane in water wells, 2009, and changes during 1978-2009: U.S. Geological Survey Scientific Investigations Report 2015-5032, 116 p., 5 app., http://dx.doi.org/10.3133/sir20155032.

ISSN 2328-031X (print)

ISSN 2328-0328 (online

ISBN 978-1-4113-3914-9 


\section{Contents}

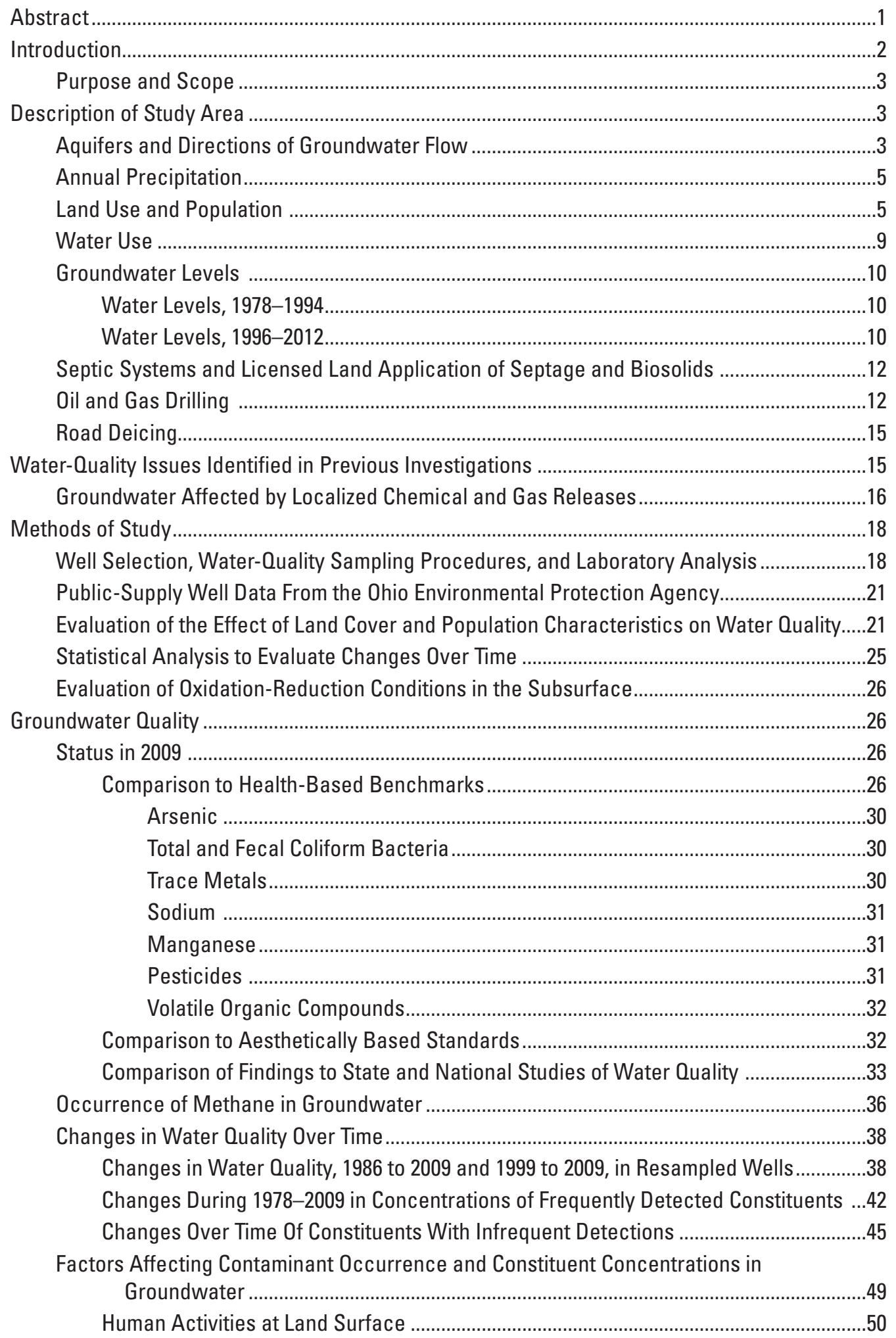


Sources of Salinity.

Other Factors That Can Influence Concentrations of Total Coliform

Bacteria, Nitrate, and Sulfate ........................................................................54

Activities Affecting Pesticide and VOC Concentrations .........................................55

Activities Affecting Bromide and Organic Carbon Concentrations ........................56

Naturally Occurring Geochemical Processes in the Subsurface ..................................57

Evolution of Groundwater Along a Flow Path ........................................................58

Ion-Exchange Reactions With Aquifer Sediments.................................................58

Oxidation-Reduction Reactions..........................................................................62

Stratigraphic Traps That May Control Areas of Methane Accumulation.........................68

Considerations for Future Work ………………….................................................................69

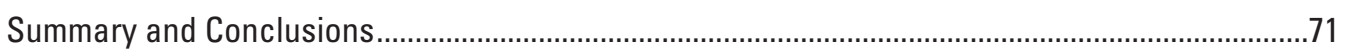

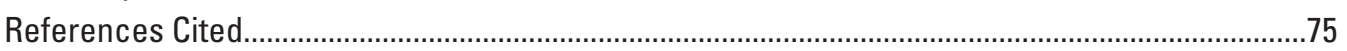

Appendix 1: Variation in Water Levels in Selected Long-Term Network Wells Relative to

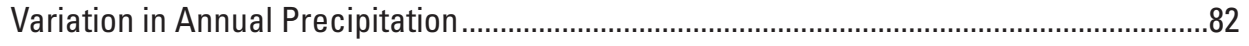

Appendix 2: Quality Assurance/Quality Control...............................................................................93

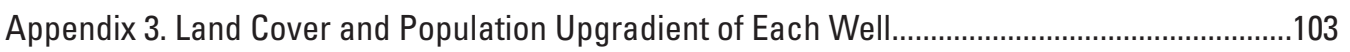

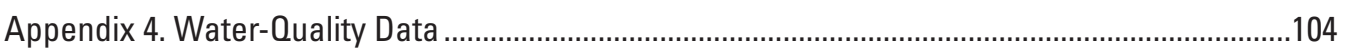

Appendix 5. Oxidation-Reduction Classification of Samples .....................................................114

\section{Figures}

1. Maps showing groundwater levels and direction of flow in Geauga County, Ohio, September 6-9, 1994, in the Pottsville Formation and glacial deposits and in the Berea Sandstone

2. Cross section showing generalized geologic section of Geauga County, Ohio................5

3. Graph showing variation in annual precipitation in Northeast Ohio relative to timing of water-quality sampling by the U.S. Geological Survey in Geauga County Ohio, 1978-2009......

4. Graph showing number of people added each decade in Geauga County, Ohio, 1950-2009.

5. Map showing population density in Geauga County, Ohio, 2000, based on the 2000 Census Blocks and the 2001 National Land Cover Database.

6. Map showing land-cover change in Geauga County, Ohio, 1992 to 2001

7. Map and graphs showing long-term groundwater-level network in Geauga County, 2009 , and comparison of water levels in selected wells, 1980-2012, to variations in annual precipitation, 1977-2012

8. Map showing authorized biosolids application sites in Geauga County, 2009, and registered septage-spreading sites, 2011

9. Map showing oil and gas wells and active Class II injection wells in Geauga County, 2008 .

10. Graph showing road-salt use in Geauga County, Ohio, 1991-2011 ..............................15

11. Map showing approximate location of sites in Geauga County, Ohio, where human effects on groundwater from industrial or commercial point sources have been documented.

12. Map showing data source and geologic unit of wells used to evaluate suitability of water for drinking, Geauga County, Ohio. 
13. Diagrams showing method used to determine area for categorizing upgradient land use and population

14. Graphs showing comparison of detection frequencies or exceedance frequencies of health-based and aesthetically based benchmarks in groundwater at the county, state, and national level.

15. Graphs showing properties and constituents with a statistically significant change in concentration from 1986 to 1999 or 1999 to 2009 in resampled wells, Geauga County, Ohio

16. Box plot showing changes in sulfate concentrations, 1978-2009, in samples from the Cuyahoga Group, Geauga County, Ohio.

17. Box plots showing changes of selected constituent ratios and concentrations in all wells sampled by the U.S. Geological Survey in Geauga County, Ohio, 1978-2009 ........45

18. Graphs showing comparison of total coliform concentrations in 1999 and 2009 in samples from wells with at least one detection, Geauga County, Ohio

19. Graphs showing detection frequency of nitrate in Geauga County, Ohio, 1978-2009, when censored to a common reporting level of 0.18 milligram per liter

20. Graph showing detection frequency of orthophosphate in Geauga County, Ohio, by aquifer, 1986-2009, when censored to a common reporting level of 0.01 milligram per liter

21. Graph showing orthophosphate concentrations, 1986-2009, for wells in Geauga County, Ohio, producing water with a concentration greater than or equal to 0.01 milligram per liter in one or more years

22. Graph showing detection frequency of total sulfide by year, Geauga County, Ohio, 1986-2009.

23. Graph showing sulfide concentrations in Geauga County, Ohio, 1999 and 2009, for wells producing water with a sulfide concentration greater than or equal to 0.01 milligram per liter in one or both years

24. Graphs showing relation of selected constituent concentrations to well depth for samples collected by the U.S. Geological Survey, Geauga County, Ohio, 1978-2009

25. Graph showing relation of chloride concentration to depth to water for samples collected by the U.S. Geological Survey in Geauga County, Ohio, 1986-2009

26. Graph showing concentration of total coliform bacteria as a function of turbidity for samples collected by the U.S. Geological Survey from domestic wells, Geauga County, Ohio, 2009.

27. Graphs showing relation of nitrate concentration to environmental characteristics for samples collected by the U.S. Geological Survey in Geauga County, Ohio, 2009.

28. Graph showing population and percent developed land use upgradient of publicsupply well fields considered in this report and domestic wells sampled in 2009, Geauga County, Ohio

29. Graph showing concentration of bromide as a function of depth to water in wells sampled by the U.S. Geological Survey, Geauga County, Ohio, 1986-2009

30. Graph showing changes from 1999 to 2009 in bromide concentrations as a function of distance of well from road for wells sampled by the U.S. Geological Survey, Geauga County, Ohio

31. Graphs showing relation of selected constituent concentrations to elevation of well bottom for samples collected by the U.S. Geological Survey, Geauga County, Ohio, 1978-2009 
32. Map showing redox condition of wells tapping the Pottsville Formation, 1978-2009, relative to groundwater flow and locations of potential sources of nitrate near land surface.

33. Box plot showing thickness of clay and shale overlying the Pottsville Formation in Geauga County, Ohio, by groundwater redox condition at sampled well locations, 1978-2009

34. Map showing locations of wells tapping a strongly reducing groundwater environment relative to locations of wells with samples that have exceeded the health-based benchmarks for arsenic or manganese, for wells sampled by the U.S. Geological Survey, Geauga County, Ohio, 1978-2009.

35 Map showing elevation of top of the Berea Sandstone in Geauga County, Ohio, and location of methane detections, June 2009.

1-1. Graphs showing relation of water levels in selected long-term network wells, 1978-2012, to variation in annual precipitation.

1-2. Graph showing relation of measured difference in water level between 1986 and 1994 to departure of water level from annual precipitation trendline, 1986 or earlier....83

2-1. Graphs showing changes in percent recovery over time for selected constituents analyzed by the National Water Quality Laboratory.

4-1. Map showing locations of wells sampled by the U.S. Geological Survey in Geauga County, Ohio, 1978-2009..

\section{Tables}

1. Percentages of land-cover types and impervious area, by township, Geauga County, Ohio, 2001

2. Water levels in well GE-147, Middlefield Township, Geauga County, Ohio, 1975-2009

3. Characteristics of wells sampled by the U.S. Geological Survey in Geauga County, Ohio, June 2009, and constituents for which water samples were analyzed.....

4. Physical characteristics of public-supply well fields considered in this report and analyses available, Geauga County, Ohio, 2000-2010

5. Exceedances of health-based benchmarks and aesthetically based standards in water quality of 16 domestic wells (2009) and 7 public-supply well fields (2000-2010) in Geauga County, Ohio.

6. Dissolved gas concentrations in selected groundwater samples from domestic wells, Geauga County, Ohio, June 2009

7. Studies of dissolved methane in residential water wells .

8. Statistical test results for differences in constituent concentrations between years in samples from wells that were able to be resampled by the U.S. Geological Survey in Geauga County, Ohio, from 1986 to 1999 or 1999 to 2009

9. Correlation of chemical properties or constituents of wells sampled by U.S. Geological Survey, 1978-2009, to year sampled.

10. Possible sources near land surface of selected constituents in groundwater.

11. Lines of evidence investigated to distinguish between sources of salinity in groundwater of Geauga County, Ohio

12. Redox conditions in groundwater samples collected by the U.S. Geological Survey during 1978-2009 in Geauga County, Ohio, threshold criteria, and associated contaminants 
1-1. Comparison of water-level difference, 1986-1994, to approximate magnitude of water-level departure from annual precipitation trendline for wells with historical data in Geauga County, Ohio.

2-1. Chemical characteristics of selected quality-control samples collected in Geauga County, Ohio, June and July 1999 and June 2009...

2-2. Expected median constituent concentrations in paired wells in 2009 based on laboratory percent recovery ratios 2009:1999

2-3. Comparison of median values of dissolved oxygen, $\mathrm{pH}$, and specific conductance in 2009 to expected variation in 1999 median values caused by measurement stabilization for 16 paired wells.

3-1. Land-cover types, population, number of acres permitted for biosolids spreading, and number of producing oil and gas wells upgradient of 16 domestic wells sampled in 2009, and 7 selected water-supply well fields in Geauga County, Ohio......103

4-1. Selected chemical characteristics of water samples collected by the U.S. Geological Survey in Geauga County, Ohio, 1978-2009

4-2. Pesticides analyzed for in groundwater samples from 16 domestic wells in Geauga County, June 2009.

4-3. Volatile organic compounds and semivolatile organic compounds analyzed for in groundwater samples in Geauga County, Ohio, 1995-2009

5-1. Redox environment classification for domestic wells sampled by U.S.

Geological Survey in Geauga County, Ohio, 1978-2009. 


\section{Conversion Factors}

\begin{tabular}{|c|c|c|}
\hline Multiply & By & To obtain \\
\hline \multicolumn{3}{|c|}{ Length } \\
\hline inch (in.) & 25.4 & millimeter $(\mathrm{mm})$ \\
\hline foot $(\mathrm{ft})$ & 0.3048 & meter $(\mathrm{m})$ \\
\hline mile (mi) & 1.609 & kilometer (km) \\
\hline \multicolumn{3}{|c|}{ Area } \\
\hline acre & 4,047 & square meter $\left(\mathrm{m}^{2}\right)$ \\
\hline acre & 0.004047 & square kilometer $\left(\mathrm{km}^{2}\right)$ \\
\hline square mile $\left(\mathrm{mi}^{2}\right)$ & 2.590 & square kilometer $\left(\mathrm{km}^{2}\right)$ \\
\hline \multicolumn{3}{|c|}{ Volume } \\
\hline milliliter (mL) & 0.03382 & ounce, fluid (fl. oz) \\
\hline gallon (gal) & 3.785 & liter (L) \\
\hline gallon (gal) & 0.003785 & cubic meter $\left(\mathrm{m}^{3}\right)$ \\
\hline million gallons (Mgal) & 3,785 & cubic meter $\left(\mathrm{m}^{3}\right)$ \\
\hline \multicolumn{3}{|c|}{ Flow rate } \\
\hline gallon per minute (gal/min) & 0.06309 & liter per second $(\mathrm{L} / \mathrm{s})$ \\
\hline gallon per day (gal/d) & 0.003785 & cubic meter per day $\left(\mathrm{m}^{3} / \mathrm{d}\right)$ \\
\hline million gallons per day (Mgal/d) & 0.04381 & cubic meter per second $\left(\mathrm{m}^{3} / \mathrm{s}\right)$ \\
\hline inch per year (in/yr) & 25.4 & millimeter per year (mm/yr) \\
\hline \multicolumn{3}{|c|}{ Mass } \\
\hline milligram (mg) & 0.00003527 & ounce, avoirdupois (oz) \\
\hline microgram $(\mu \mathrm{g})$ & 1,000 & milligram (mg) \\
\hline \multicolumn{3}{|l|}{ Radioactivity } \\
\hline picocurie per liter $(\mathrm{pCi} / \mathrm{L})$ & 0.31 & tritium units \\
\hline picocurie per liter (pCi/L) & 0.037 & becquerel per liter $(\mathrm{Bq} / \mathrm{L})$ \\
\hline
\end{tabular}

Temperature in degrees Celsius $\left({ }^{\circ} \mathrm{C}\right)$ may be converted to degrees Fahrenheit $\left({ }^{\circ} \mathrm{F}\right)$ as follows: ${ }^{\circ} \mathrm{F}=\left(1.8 x^{\circ} \mathrm{C}\right)+32$

Temperature in degrees Fahrenheit $\left({ }^{\circ} \mathrm{F}\right)$ may be converted to degrees Celsius $\left({ }^{\circ} \mathrm{C}\right)$ as follows: ${ }^{\circ} \mathrm{C}=\left({ }^{\circ} \mathrm{F}-32\right) / 1.8$

Vertical coordinate information is generally referenced to the National Geodetic Vertical Datum of 1929 (NGVD 29) for wells first sampled 1978 to 1986 and to the North American Vertical Datum of 1988 (NAVD 88) for wells sampled only in 1999 and 2009.

Horizontal coordinate information is generally referenced to the North American Datum of 1927 (NAD 27) for wells first sampled 1978 to 1986. For wells sampled only in 1999 and 2009, horizontal coordinates are generally referenced to the North American Datum of 1983 (NAD 83). 
Elevation, as used in this report, refers to distance above the vertical datum.

Specific conductance is given in microsiemens per centimeter at 25 degrees Celsius $\left(\mu \mathrm{S} / \mathrm{cm}\right.$ at $\left.25^{\circ} \mathrm{C}\right)$.

Concentrations of chemical constituents in water are given either in milligrams per liter (mg/L) or micrograms per liter ( $\mu \mathrm{g} / \mathrm{L})$.

\section{Other abbreviations used in this report:}

$\begin{array}{ll}\text { DCA } & \text { Dichloroethane } \\ \text { DWA } & \text { Drinking Water Advisory } \\ \text { HA-C } & 10^{-6} \text { Cancer Risk Concentration } \\ \text { HA-L } & \text { Lifetime Health Advisory } \\ \text { MCL } & \text { Maximum Contaminant Level } \\ \text { NTU } & \text { Nephelometric turbidity unit } \\ \text { OAC } & \text { Ohio Administrative Code } \\ \text { Ohio EPA } & \text { Ohio Environmental Protection Agency } \\ \text { ODNR-MRM } & \text { Ohio Department of Natural Resources, Division of Mineral Resources Management } \\ \text { PCE } & \text { Perchloroethene } \\ \text { SMCL } & \text { Secondary Maximum Contaminant Level } \\ \text { TCE } & \text { Trichloroethene } \\ \text { USEPA } & \text { U.S. Environmental Protection Agency } \\ \text { USGS } & \text { U.S. Geological Survey } \\ \text { VOC } & \text { Volatile Organic Compound }\end{array}$




\section{Acknowledgments}

The authors would like to thank the 16 homeowners who have allowed USGS personnel to collect water samples from their wells — some of them for the past three decades. Additionally, the authors appreciate the valuable assistance during the data-gathering process of Linda Slattery at Ohio Environmental Protection Agency, Division of Drinking and Ground Waters; Rick Simmers and Tom Tomastik at Ohio Department of Natural Resources-Mineral Resources Management; David Dietrich, Geauga County Planning Director; the Geauga County Engineer's office; and Bob Weisdack, Geauga County Health Commissioner. 


\title{
Groundwater Quality in Geauga County, Ohio- Status, Including Detection Frequency of Methane in Water Wells, 2009, and Changes During 1978-2009
}

\author{
By Martha L. Jagucki, Stephanie P. Kula, and Brian E. Mailot
}

\section{Abstract}

Domestic wells that are not safeguarded by regular waterquality testing provide drinking water for 79 percent of the residents of Geauga County, in northeastern Ohio. Since 1978, the U.S. Geological Survey (USGS) has worked cooperatively with the Board of Commissioners and Geauga County Planning Commission to monitor the quality of groundwater in four commonly used aquifers in county - the glacial deposits, the Pottsville Formation, the Cuyahoga Group, and the Berea Sandstone. A 33-percent growth in population from 1980 to 2009 increased the potential for humans to influence groundwater resources by withdrawing more groundwater, disposing of more human waste near the land surface, treating an expanded network of township roads with deicing salt, and likely using more solvents, pesticides, and other chemicals on the land surface than were used in preceding decades.

To describe the status of groundwater quality in 2009 and its suitability for drinking, USGS personnel collected samples of water prior to treatment from 16 wells (mostly domestic) during June 9-19. The samples were analyzed for 92 properties and constituents, 41 of which had human-health benchmarks to which analytical results could be compared to evaluate suitability for drinking. Four of these benchmarks were exceeded at the following frequencies: arsenic ( 2 of 16 wells, 12.5 percent), total coliform bacteria ( 2 of 16 wells, 12.5 percent), fecal coliform bacteria ( 1 of 14 wells, 7 percent), and sodium ( 6 of 16 wells, 38 percent). No domestic wells sampled in 2009 exceeded the health-based benchmark of 300 micrograms per liter $(\mu \mathrm{g} / \mathrm{L})$ for manganese, although 5 of 65 wells ( 8 percent) sampled since 1978 have. Analyses from domestic wells were augmented with water-quality data from seven public-supply well fields that were obtained from the Ohio Environmental Protection Agency. These public-supply data were typically collected between 2000 and 2010 and represent water samples that were collected prior to treatment or that were treated by a method that does not effectively remove the constituents of interest. Similar to the domestic-well data, these data indicated that some samples from public-supply wells have also exceeded health-based benchmarks for arsenic and sodium, along with occasional exceedances of healthbased benchmarks for cadmium and lead. Concentrations of nitrate, pesticides, and volatile organic compounds in groundwater samples from domestic and (or) public-supply wells were either considerably less than the human-health benchmarks for these constituents or were not detected.

Water-quality data collected in 2009 were also compared to aesthetically based benchmarks developed by the U.S. Environmental Protection Agency, called Secondary Maximum Contaminant Levels (SMCLs). Iron and manganese most frequently exceeded SMCLs (in samples from 10 of 16 domestic wells and in untreated water from 3 of 4 publicsupply well fields).

To evaluate the frequency of methane detection in water wells in the county, the USGS sampled 16 wells across the county and screened the samples for combustible gas within the headspace (the air above the water in a closed container). Water from three (19 percent) of the wells contained detectable combustible gas ( 0.10 to 0.40 percent by volume). All three detections were from wells tapping the Cuyahoga Group or the Berea Sandstone, and all detections were less than the lower explosive limit of 5 percent by volume - the concentration at which methane in air can be flammable if an ignition source is present. Analyses of dissolved gas composition in water from these three wells showed methane concentrations ranging from 0.007 to 1.8 milligrams per liter $(\mathrm{mg} / \mathrm{L})$.

The primary effect of human activities on groundwater quality found during this study is the input of salinity, or chloride, near land surface. On the basis of ratios of chloride to bromide, the main sources of chloride are road salt and septic leachate rather than oil-field brines (either spilled at land surface or sprayed on roads for dust control). The correlation of chloride concentration to distance of well from road for 31 wells in the county sampled by the U.S. Geological Survey in 1999 suggests that road salt is the dominant source of chloride.

The majority of constituents exceeding health-based and aesthetically based benchmarks in groundwater were those that are naturally present in aquifer rocks and sediments rather than constituents introduced by human activities. Concentrations 


\section{Groundwater Quality in Geauga County, Ohio-Status, 2009, and Changes During 1978-2009}

of such natural contaminants are controlled by geochemical processes in the subsurface, particularly by oxidationreduction (redox) reactions. The categorization of redox conditions based on the water quality of 116 samples collected from 65 wells in Geauga County during 1978 through 2009 indicates that most groundwater samples were strongly reducing (60 percent) or oxic (18 percent). Oxic waters were found only in the Pottsville Formation and Berea Sandstone and were generally associated with nitrate at concentrations of 0.38 to $6.0 \mathrm{mg} / \mathrm{L}$. Strongly reducing waters occurred in all four commonly used aquifers and were associated with the following naturally occurring contaminants: (1) arsenic and manganese at concentrations exceeding the health-based benchmarks $(10 \mu \mathrm{g} / \mathrm{L}$ and $300 \mu \mathrm{g} / \mathrm{L}$, respectively) in some samples, (2) iron and manganese at concentrations exceeding the aesthetically based standards $(300 \mu \mathrm{g} / \mathrm{L}$ and $50 \mu \mathrm{g} / \mathrm{L}$, respectively) in most samples, and (3) total sulfides (consisting of hydrogen sulfide gas with its characteristic rotten-egg odor and [or] iron sulfide minerals that appear as finely disseminated particulates in water).

Because of the association of redox conditions with specific contaminants, attempts were made to further document spatially where oxic and strongly reducing conditions occur so that contaminant occurrence can be better anticipated by planners and well owners. Within the Pottsville Formation, wells tapping strongly reducing groundwater tended to have a greater thickness of overlying low-permeability (recharge-inhibiting) material such as clay and shale than other wells tapping oxic or nitrate-reducing groundwater. In the Berea Sandstone, oxic conditions were found at well locations where either depth to groundwater was shallow (less than 45 feet [ft] below land surface) or the measured water level was within the open interval (uncased portion) of the well, whereas strongly reducing groundwater was found at well locations where depths to water were greater than $60 \mathrm{ft}$ below land surface and measured water levels were $15 \mathrm{ft}$ or more above the open interval of the well.

To evaluate whether constituent concentrations consistently increased or decreased over time, the strength of the association between sampling year (time) and constituent concentration was statistically evaluated for 116 water-quality samples collected by the USGS in 1978, 1980, 1986, 1999, and 2009 from a total of 65 wells across the county (generally domestic wells or wells serving small businesses or churches). Results indicate that many of the constituents that have been analyzed for decades exhibited no consistent temporal trends at a statistically significant level (p-value less than 0.05); fluctuations in concentrations of these constituents represent natural variation in groundwater quality. Dissolved oxygen, calcium, and sulfate concentrations and chloride:bromide ratios increased over time in one or more aquifers, while $\mathrm{pH}$ and concentrations of bromide and dissolved organic carbon decreased over time. Detections of total coliform bacteria and nitrate did not become more frequent from 1986 to 2009, even though potential sources of these constituents, such as number of septic systems (linked to population) and percent developed land in the county, increased during this period.

\section{Introduction}

Groundwater in Geauga County, Ohio, is an important resource because it is the primary drinking-water supply for over 98 percent of residents in the county (Kenney and others, 2009). For the past three decades, the U.S. Geological Survey (USGS) has worked in cooperation with the Board of Commissioners to evaluate the potential effects of human development and changing land use on the quantity and quality of groundwater resources in the four primary aquifers used in the county - the glacial deposits, the Pottsville Formation, the Cuyahoga Group, and the Berea Sandstone.

The initial investigation of groundwater quantity in the county began in 1978, when the USGS measured water levels in 77 wells and produced a generalized water-level map of the uppermost bedrock aquifers (Nichols, 1980). To better understand the groundwater flow system and to predict future water-level changes on the basis of forecasted population growth and water use, the USGS measured water levels in 125 wells in 1986 and developed a numerical computer model (Eberts and others, 1990). Because the computer model had predicted that an increase in population might cause water-level declines in some areas, water levels were again measured in 1994-this time in 219 wells. Detailed maps showing directions of flow in the four primary aquifers were constructed, and changes in water level from 1986 to 1994 were evaluated in 88 wells that were able to be remeasured (Jagucki and Lesney, 1995). Water levels in 70 percent of the wells had declined between 1986 and 1994, although it was not clear whether this was a temporary fluctuation caused by less precipitation in 1994 than in 1986 or was a lasting decline caused by greater groundwater withdrawals in 1994 than in 1986 due to population growth. To distinguish between these two factors and to establish a framework for long-term waterlevel monitoring, a network of 31 wells was established in 1996 in which depth to groundwater is regularly measured (ongoing as of the date of writing). Water-level variations in each well are routinely compared to variations in annual precipitation.

Groundwater quality in the four primary aquifers used in the county has also been assessed as part of past USGS studies. Water-quality samples were collected primarily from domestic wells or from drinking-water wells at small businesses, churches, rest stops, or parks in 1978 (Nichols, 1980; 14 samples), 1980 (U.S. Geological Survey, 1981; 24 samples), 1986 (Eberts and others, 1990; 42 samples), and 1999 (Jagucki and Darner, 2001; 31 samples). Statistical differences in water quality between aquifers were described by Jagucki and Darner (2001). 


\section{Purpose and Scope}

The purpose of this report is to (1) describe the status of groundwater quality in 2009 in the four primary aquifers used in Geauga County, (2) describe the detection frequency of methane in water wells in the county in 2009, and (3) determine whether statistically significant changes in water quality had occurred since 1978. To determine the status of groundwater quality in 2009, USGS personnel collected samples from 16 domestic wells during June 9-19, 2009. These analyses were augmented with water-quality data from seven public-supply well fields collected during 2000-2010 and on file with the Ohio Environmental Protection Agency (Ohio EPA). Water-quality analyses from both sources were compared to health-based and aesthetically based drinkingwater benchmarks to identify present-day constituents of concern (manmade or naturally occurring groundwater contaminants) in Geauga County groundwater. To determine the detection frequency of methane in water wells in the county, water from each of the 16 domestic wells sampled in 2009 was screened for combustible gases, with a positive detection prompting laboratory analysis for dissolved methane. Changes in water quality over time were evaluated by (1) statistically comparing constituent concentrations in samples from 1999 to those of 2009 for the 16 domestic wells that were able to be sampled by the USGS in both years, (2) assessing the statistical relation between constituent concentration and sampling year using all USGS water-quality data for the county - as many as 116 samples collected in 1978, 1980, 1986, 1999, and 2009 from 65 wells - and (3) examining detection frequencies of selected constituents by year. Finally, data from all 116 USGS samples were used to assess whether factors such as depth to groundwater, well location, well elevation, aquifer tapped by well, or well construction were correlated to constituent concentrations in groundwater. Such knowledge may help well owners and planners understand where specific constituents of concern might occur.

\section{Description of Study Area}

Geauga County is in northeastern Ohio and covers approximately 409 square miles (mi²) (fig. 1) The hilly topography and location relative to Lake Erie cause moistureladen winds from the lake to release rain and snowfall on the Geauga County uplands. Average annual precipitation for the period 1971 to 2000 ranged from 40.2 inches per year (in/yr) near the south edge of the county to 46.4 in/year in Chardon and Hambden Townships, in the northern part of the county (PRISM Climate Group, 2006). Characteristics of the study area with the potential to influence groundwater quality are described in the following paragraphs.

\section{Aquifers and Directions of Groundwater Flow}

Aquifers used to supply drinking water in Geauga County were mapped and described in detail by Eberts and others (1990). Directions of groundwater flow were determined by Eberts and others (1990) and Jagucki and Lesney (1995). These findings are briefly summarized below. Four main aquifers are utilized for drinking water in the county, including three layered bedrock units (the Pottsville Formation, Cuyahoga Group, and Berea Sandstone) and the overlying glacial sediments (fig. 2). Some of the bedrock layers have been eroded in stream valleys and along the edges of the county. Often the stream valleys are filled with glacial sediments, in some places to depths of more than 200 feet (ft). Precipitation is the source of virtually all groundwater within the county (Eberts and others, 1990). Under typical flow conditions, some precipitation will infiltrate from land surface to the water table, where it then flows downward and laterally over time through the hydraulically connected glacial sediments and Pottsville Formation. The Pottsville Formation consists of interbedded sandstones that readily transmit water. In some places, however, discontinuous patches of shale are present between sandstone layers that locally inhibit downward groundwater movement. Water flowing through the glacial sediments and the Pottsville Formation may discharge to nearby streams (figs. $1 A$ and 2), creating isolated flow cells on each hilltop.

Not all groundwater in the Pottsville Formation discharges to local streams; some groundwater reaches the base of the Pottsville Formation and flows downward into the underlying Cuyahoga Group, which is a thick sequence of interbedded shales and sandstones that is much less permeable than the surrounding bedrock layers. At shallow depths and where much overlying rock has been eroded (as is shown at the eastern edge of fig. 2), the Cuyahoga Group is fractured and groundwater flows horizontally through the fractures, joints, and bedding planes; however, through most of the formation's thickness, groundwater flow is almost vertical and the formation acts as a leaky confining unit, greatly slowing the movement of water into lower layers. Once through the Cuyahoga Group, water enters the underlying Berea Sandstone and resumes flowing in a primarily lateral direction and at a relatively rapid rate compared to that in the Cuyahoga Group. The direction of groundwater flow in the Berea Sandstone is generally from the center of the county toward the outer edges of the county (fig. 1B), where it discharges into major stream valleys and to springs. It is primarily near these discharge areas along the outer edges of the county - where overlying aquifers have been eroded (fig. 2) - that the Berea Sandstone is tapped for drinking water. The groundwater residence time, or time that it takes for groundwater to travel from the water table to various discharge points at streams and springs, is shown in figure 2, as estimated by Eberts and others (1990) 


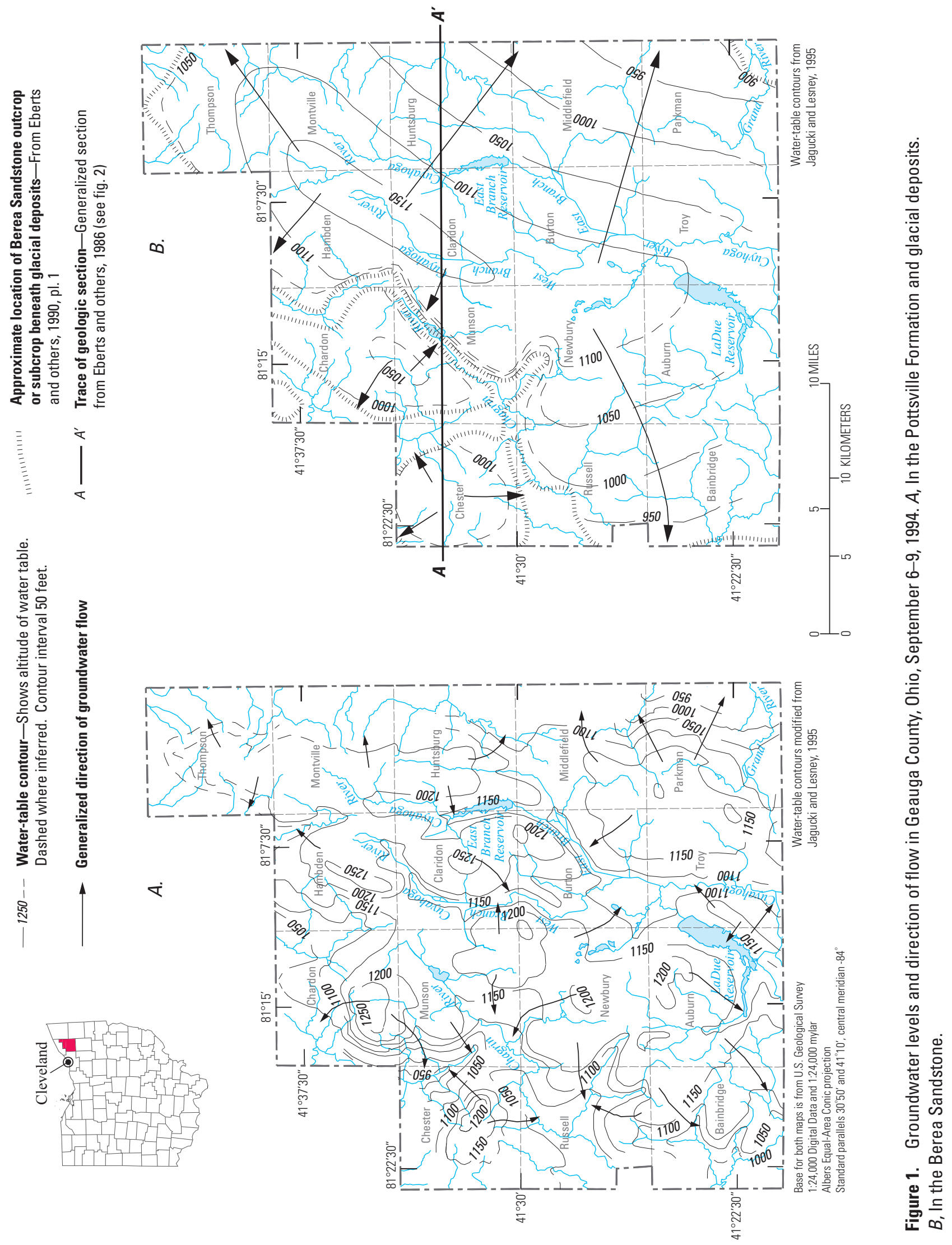




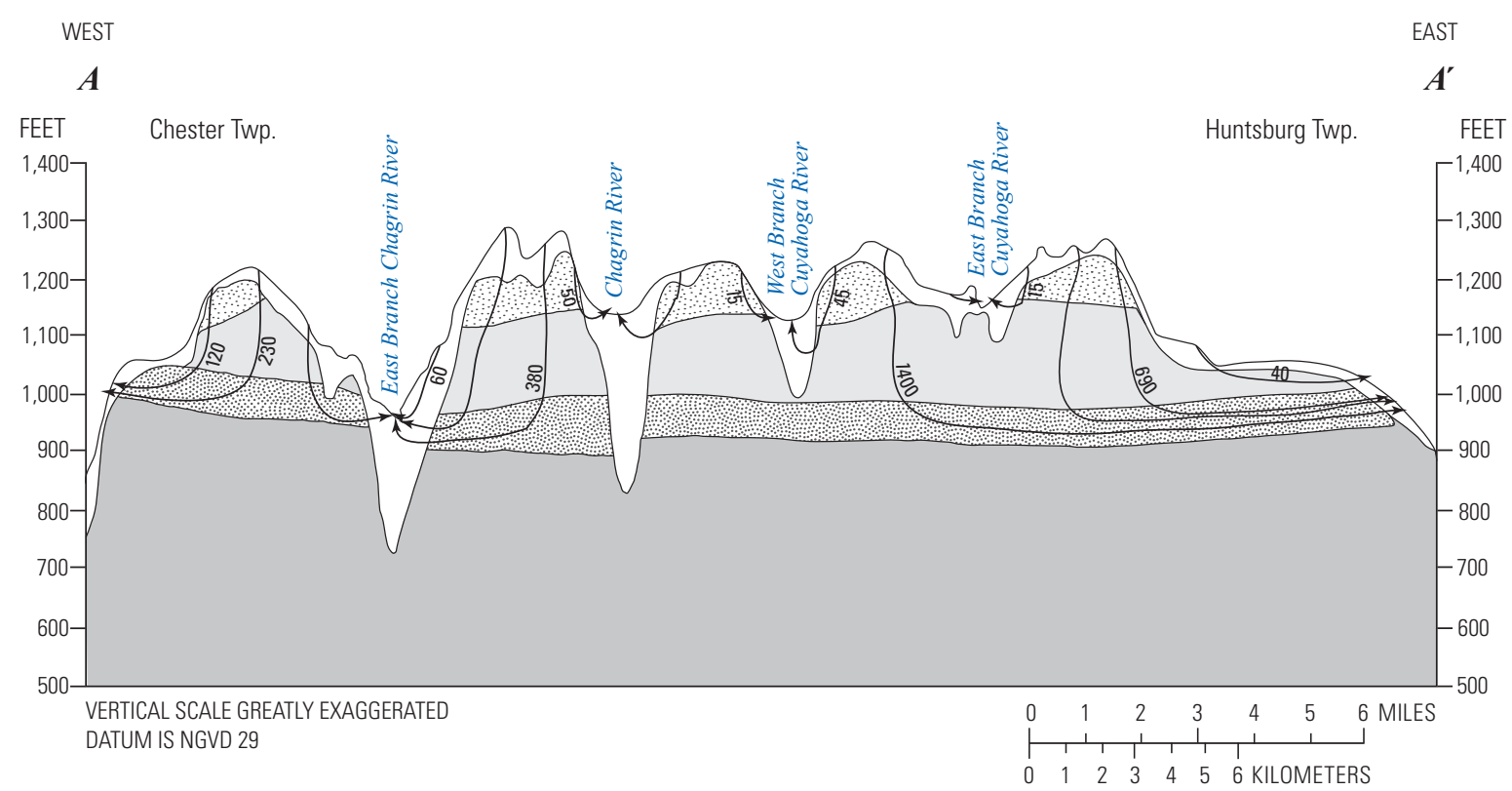

EXPLANATION

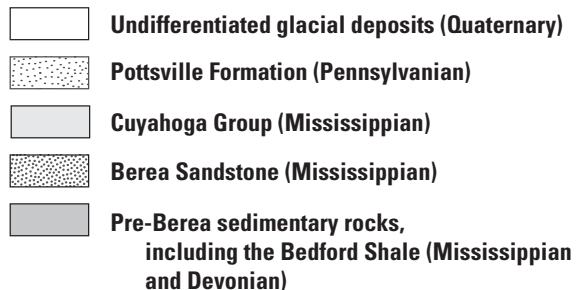

Simulated groundwater flow path-

Number, where shown, is simulated groundwater residence time, in years

Figure 2. Generalized geologic section of Geauga County, Ohio (modified from Eberts and others, 1990). Trace of section $A-A^{\prime}$ is shown on figure 1.

using a computer model to simulate groundwater flow. The amount of residence time can affect water quality; the longer groundwater is in contact with aquifer materials, the more minerals dissolve into groundwater and the more oxygen depleted the groundwater becomes.

\section{Annual Precipitation}

The amount of precipitation in the year preceding a groundwater-sampling event can affect water qualityparticularly in shallow wells that receive direct recharge from precipitation infiltration to the water table. Precipitation amounts in the calendar year prior to the 1978, 1980, and 1986 sampling rounds were roughly comparable, at about 5 inches (in.) above normal (fig. 3). Only the sampling round in 1999 was preceded by 1 or more years of below-normal rainfall. The 2009 sampling round was unique, in that precipitation was 4.33 to $10.74 \mathrm{in}$. above normal for 6 consecutive years prior to groundwater-sample collection (fig. 3). Above-normal annual rainfall increases recharge and can either dilute constituent concentrations in shallow groundwater or add dissolved constituents from a source at land surface.

\section{Land Use and Population}

Increasing population brings with it a greater potential for harmful human effects on groundwater resources, including larger groundwater withdrawals and potential contamination from a greater number of septic systems, roads treated with deicing salt, and industrial and retail facilities that use solvents, pesticides, and other chemicals. An estimated 26,646 people lived in Geauga County in 1950 (U.S. Census Bureau, 2014), compared to 99,060 residents in 2009 (U.S. Census Bureau, 2010). Population growth was most rapid during the 1950s and 1960s (fig. 4), when population increased by 36,331 people. It took another 39 years (1970 to 2009) for an additional 36,083 people to be added to the county (U.S. Census Bureau, 2014), with population growth being slowest during the 1980s. The average population density of the county increased from 184 persons per square mile in 1980 to 245 in 2009 (roughly the period for which water-quality data are available). Population density varies widely, with the townships in the western part of the county being historically the most densely populated (fig. 5) and continuing to develop (fig. 6) because of their proximity to Cleveland and Cuyahoga County. 
6 Groundwater Quality in Geauga County, Ohio-Status, 2009, and Changes During 1978-2009

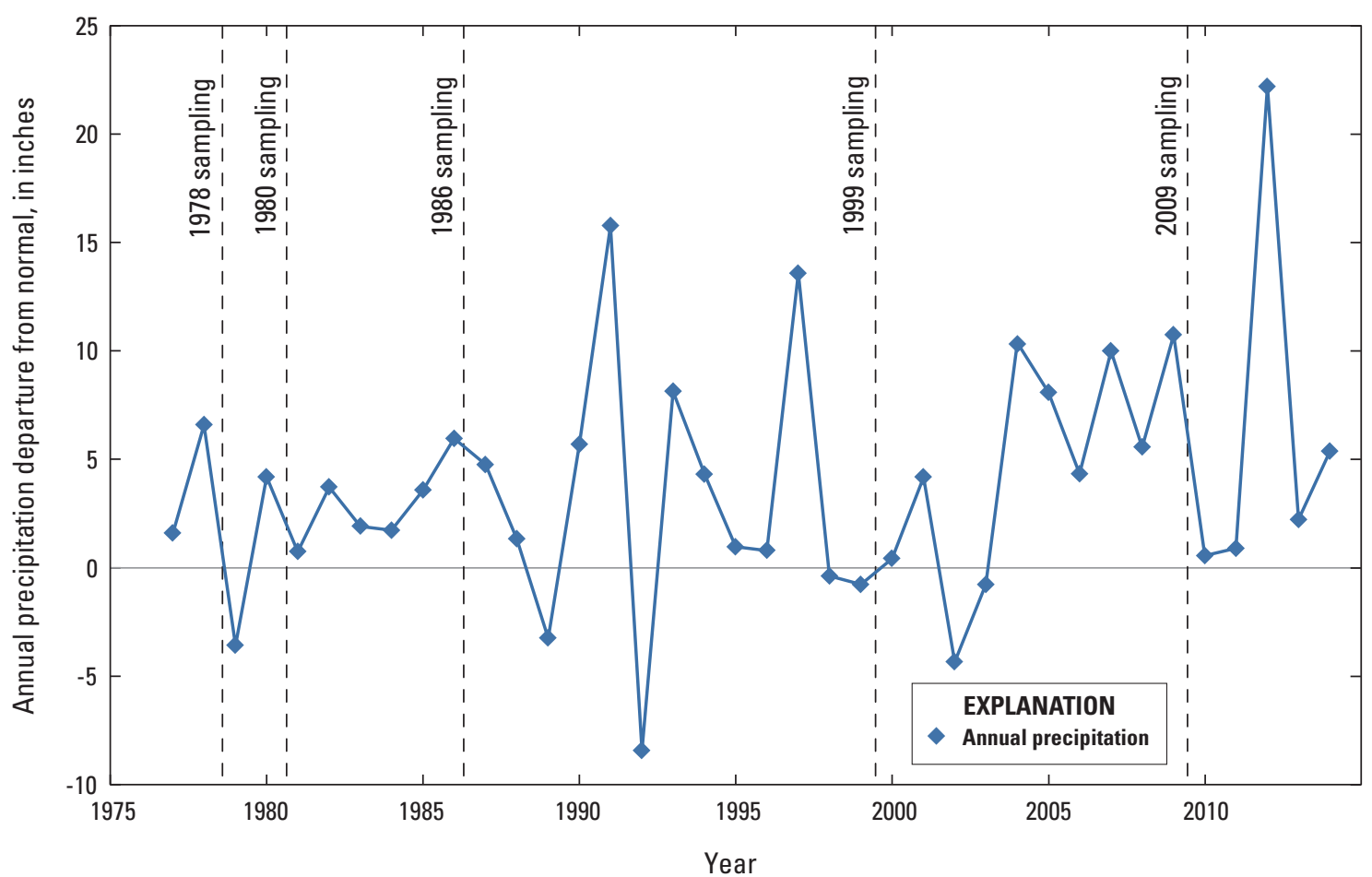

Figure 3. Variation in annual precipitation in Northeast Ohio relative to timing of water-quality sampling by the U.S. Geological Survey in Geauga County Ohio, 1978-2009. (Annual precipitation data are departure from normal for the climatological Northeast Region of Ohio [Ohio Department of Natural Resources, 1976-2013]. “Normal precipitation" and plotting conventions are described in appendix 1.)

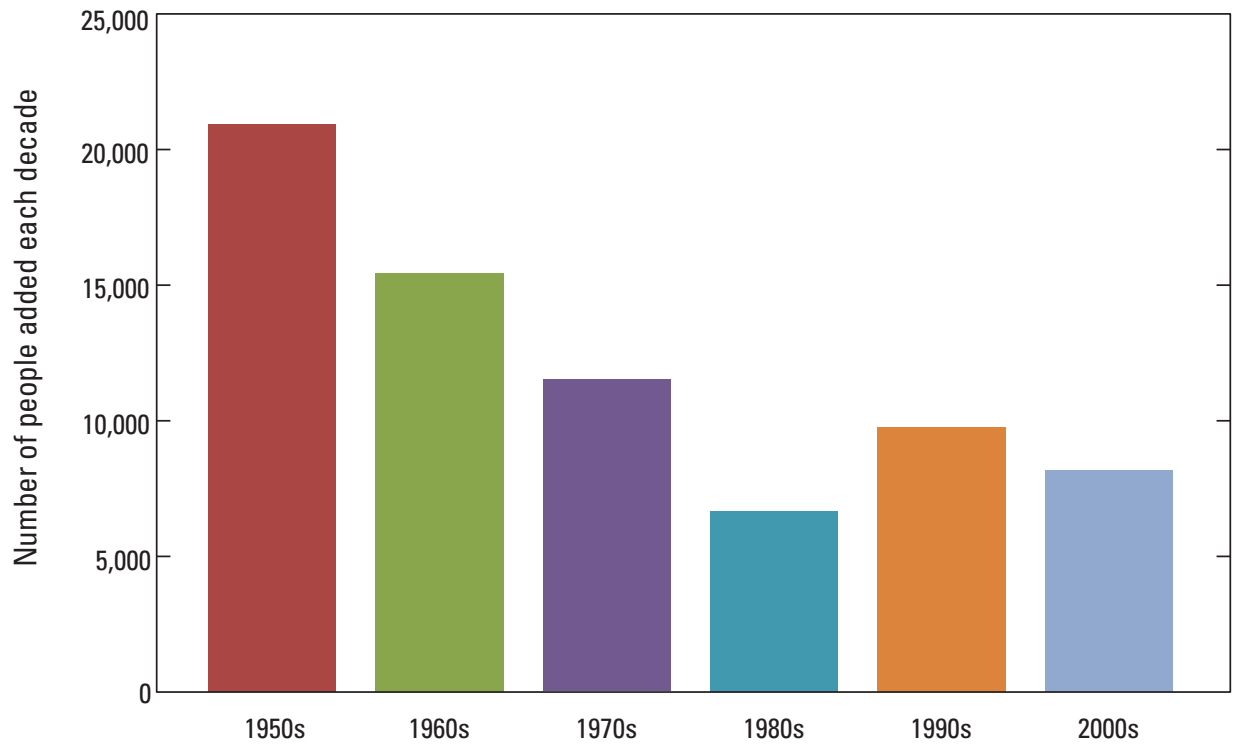

Figure 4. Number of people added each decade in Geauga County, Ohio, 1950-2009. (Data from U.S. Census Bureau, 2010, 2014.) 


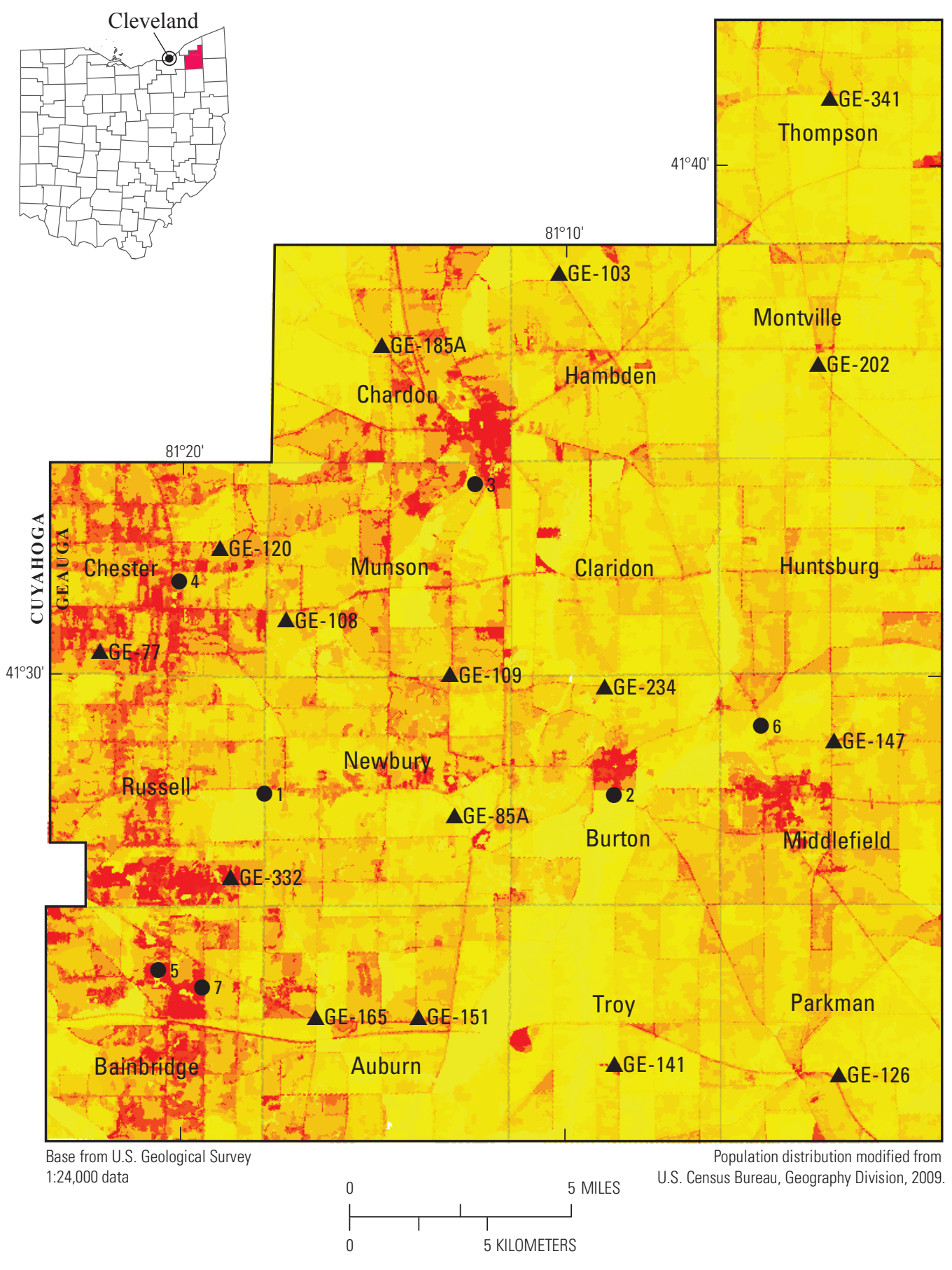

EXPLANATION

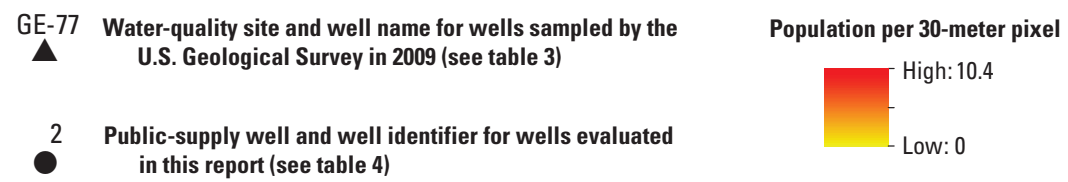

Figure 5. Population density in Geauga County, Ohio, 2000, based on the 2000 Census Blocks and the 2001 National Land Cover Database. 


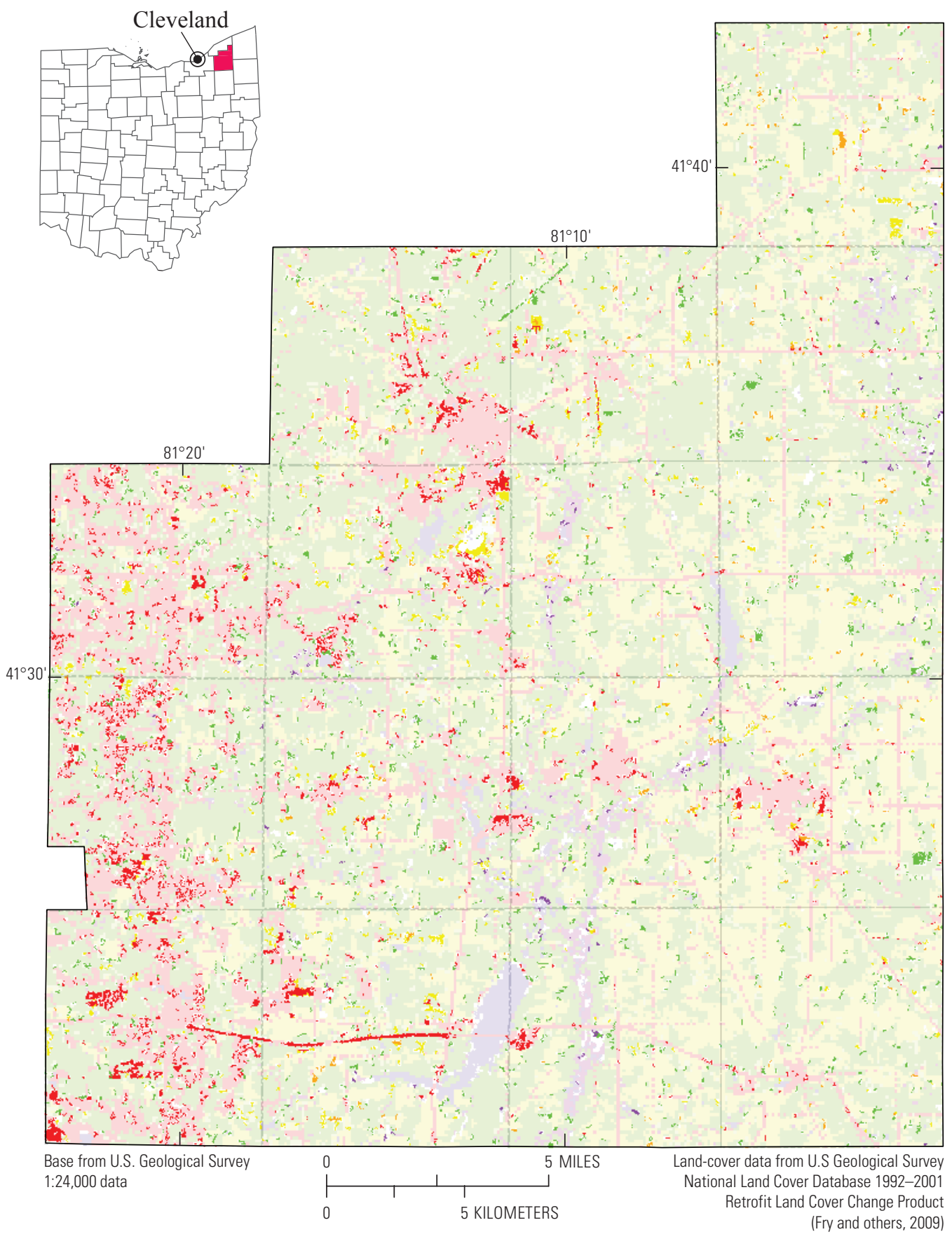

EXPLANATION

Changed during 1992-2001

Agriculture or Forest to Urban

Agriculture or Forest to Wetland

Agriculture to Forest or Grass/shrub

Forest to Agriculture

Forest to Grass/shrub or Barren

Other
Same in 1992 and 2001

Agriculture

Barren

Forest

Grass/shrub

Open water

Urban

Wetland

Figure 6. Land-cover change in Geauga County, Ohio, 1992 to 2001. 
Unfortunately, differences in how land use has been categorized over the years - particularly large-lot residential properties - makes it difficult to compare land use from several decades ago to that of recent years. Total land cover acreage per category changed little between 1992 and 2001 (fig. 6), years in which comparable data could be obtained. Less than 2 percent of land that was in agriculture or forest in 1992 was converted to developed land cover by 2001, and about 1.4 percent of land that was in agriculture in 1992 was converted to forest, grassland, or shrub by 2001.

In 2001, about 16 percent of Geauga County's area was developed land, though mainly consisting of open space such as the lawns of large-lot single-family houses, golf courses, and parks (table 1). Almost half of the area of the county was forested, and agriculture accounted for about 25 percent of the county's area. It is estimated that only 2.9 percent of the surface of Geauga County was covered with impervious materials such as rooftops, roads, and parking lots in 2001.

\section{Water Use}

County water use was first estimated in 1975 by compiling withdrawal data from water utilities, rural homeowners, industrial and commercial facilities, and irrigators. Total groundwater withdrawals have increased over time, from an estimated 4.9 million gallons per day in 1975 (Hathaway and Eberle, 1981) to 7.1 million gallons per day in 2005 (Kenny and others, 2009). An increase in groundwater withdrawals can cause groundwater levels to decline and can potentially affect water quality by drawing water into a well from different aquifers or parts of an aquifer than were accessed when smaller volumes of water were pumped.

In 2005 , the majority of groundwater (79 percent) used in the county was self-supplied water withdrawn from domestic wells for purposes of drinking, food preparation, washing, flushing toilets, and watering lawns and gardens (Kenny and others, 2009). Unlike drinking water supplied by

Table 1. Percentages of land-cover types and impervious area, by township, Geauga County, Ohio, 2001.

[Impervious and land-cover data from National Land Cover Database (Homer and others, 2007)]

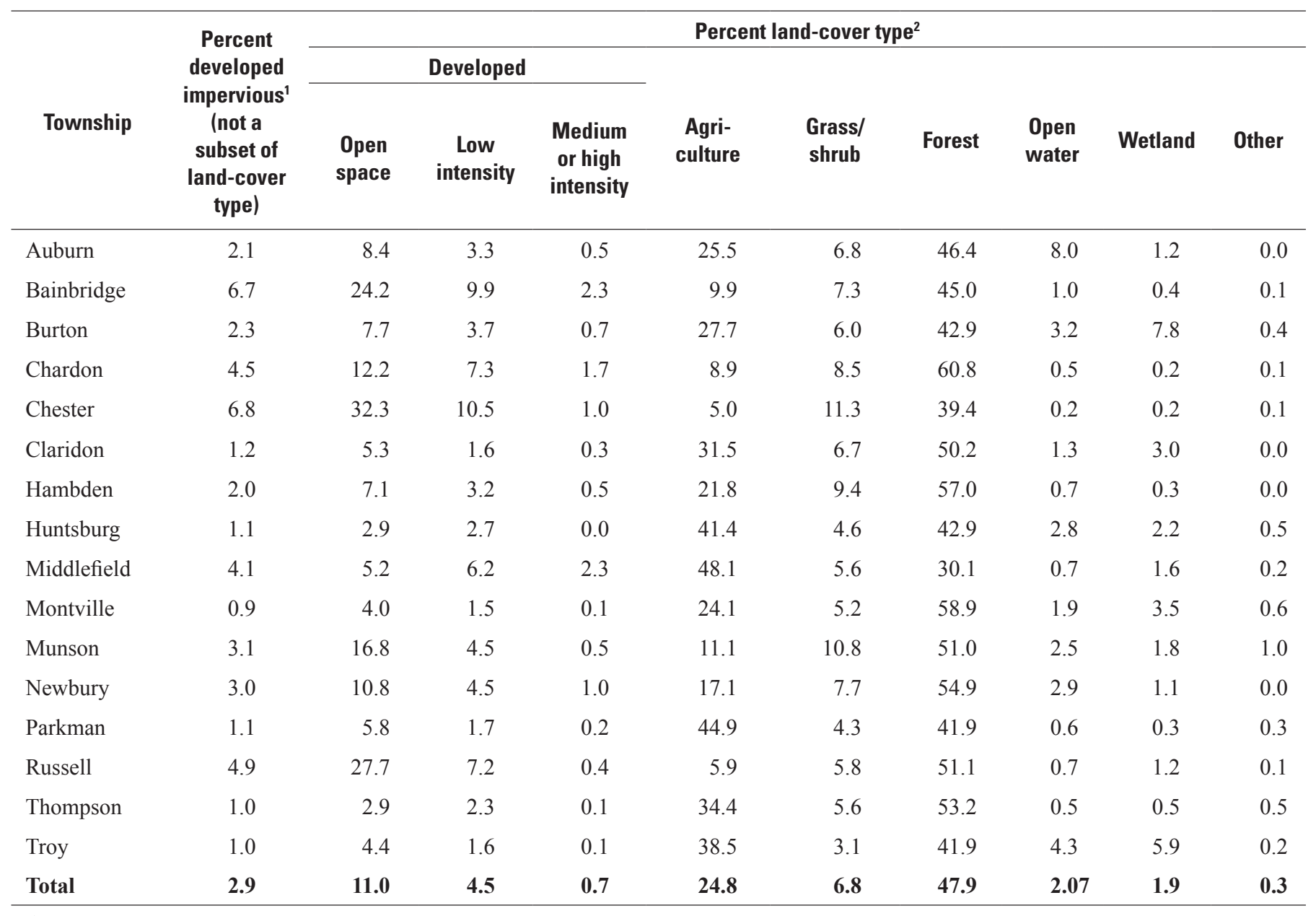

${ }^{1}$ Percent impervious and land-cover classes are determined by the spectral signatures of the Landsat satellite sensors. The classes of developed land cover are derived from the percent developed impervious as follows: developed open space, less than 20 percent impervious; developed low intensity, 20-49 percent impervious; developed medium or high intensity, greater than 50 percent impervious.

${ }^{2}$ Summed land-cover percentages for a township may not total 100 percent because of rounding. 


\section{Groundwater Quality in Geauga County, Ohio-Status, 2009, and Changes During 1978-2009}

public-supply wells (wells that serve 25 or more individuals for at least 60 days a year and have regular water-testing requirements regulated by Ohio EPA), water from domestic wells is not safeguarded by mandatory periodic testing of water quality but instead relies on voluntary testing contracted by homeowners.

\section{Groundwater Levels}

The long-term groundwater-level monitoring network in Geauga County consists of 31 wells that tap the four primary aquifers used in the county (fig. 7). Water levels in network wells were measured six times a year during 1996-2012 and four times a year thereafter. Continuous (hourly) water levels have been recorded in a subset of six wells shown as pink circles in figure 7. Hydrographs (plots of water-level changes over time) for all network wells are available at http://groundwaterwatch.usgs.gov/countymap.asp?sa $=\mathrm{OH} \& \mathrm{cc}=055$.

\section{Water Levels, 1978-1994}

Intermittent water-level data from previous studies (Nichols, 1980; U.S. Geological Survey, 1981; Eberts and others, 1990) are available for 13 of the 31 network wells (denoted by squares in fig. 7), beginning in 1978, 1980, 1985, or 1986. Hydrographs for these 13 wells are shown relative to fluctuations in annual precipitation in appendix figures $1-1 A$ and $B$. Visual inspection of these plots indicates that intermittent water-level data collected at network wells during previous studies can be classified as either (a) shallower than expected on the basis of historic precipitation variations, indicating that water levels have declined over time in the vicinity of the well (fig. 7, hydrograph $A$ ), or (b) within the depth range expected on the basis of historic annual precipitation data (denoted by orange squares in fig. 7, and exemplified by hydrograph $B$ ) - meaning that water levels in the late 1970 s and 1980s were comparable to water levels in the late $1990 \mathrm{~s}$ and 2000s. In 10 of the 13 wells with intermittent data from previous studies, water levels declined in the 1980s (denoted by green squares in fig. 7). Water-level declines occurred at wells in several townships and in wells tapping each of the four primary aquifers (fig. 7).

Water-level declines in the 1980s were likely much more widespread than indicated by just the 10 wells with green squares (fig. 7). Quantification of water-level fluctuations in network wells due to variations in annual precipitation has allowed reinterpretation of water-level comparisons (1986 to 1994) made by Jagucki and Lesney (1995). The conclusion of this reinterpretation (appendix 1) is that water-level declines of $1 \mathrm{ft}$ or more measured between 1986 and 1994 in 50 of 88 wells (57 percent) were not a response to fluctuations in annual precipitation amounts. Instead, water levels measured in the 1980s in these wells were likely still adjusting to the rapid population growth (fig. 4) and the associated increased groundwater withdrawals that occurred from 1950 to 1970. Declines likely began before water levels were first measured, with slowing population growth in the 1980s allowing water levels in most wells to stabilize by the mid-1990s. A second contributing factor to the observed water-level declines in some wells could be the magnitude 5.0 earthquake that occurred on January 31, 1986 (epicenter just north of Hambden Township, fig. 7). This earthquake may have created new bedrock fractures that increased aquifer drainage and discharge (appendix 1). Jagucki and Lesney (1995) noted that water-level declines between 1986 and 1994 occurred in all four aquifers but that the greatest water-level declines (more than $10 \mathrm{ft}$ ) were measured primarily in wells tapping the Cuyahoga Group and Berea Sandstone.

\section{Water Levels, 1996-2012}

During 1996-2012, water levels in most wells were stable, with fluctuations mimicking variations in annual precipitation. However, water levels in 4 of the 31 network wells - GE-119, GE-136, GE-349, and GE-352 — began declining sometime after 1996 (appendix fig. 1-1C). In most cases a new pumping source, drilled at about the same time that the water-level decline began, was identified near the network well. The difference in average water level before and after a decline ranged from about 0.5 to $5.2 \mathrm{ft}$. These "recent" water-level declines have been noted in three aquifers - the glacial deposits, Pottsville Formation, and Cuyahoga Group. Three of the four wells where water levels recently declined are in Middlefield Township. The water level in an additional well in Middlefield Township (GE-147, fig. 5), which is not part of the long-term groundwater-level network but has been periodically measured prior to water-quality sampling, began to decline prior to 1986 and has continued to decline significantly in recent years (table 2).

Table 2. Water levels in well GE-147, Middlefield Township, Geauga County, Ohio, 1975-2009.

\begin{tabular}{rc}
\hline Date & $\begin{array}{c}\text { Depth to water, in feet below land } \\
\text { surface }\end{array}$ \\
\hline $1 / 31 / 1975$ & Overflowing $^{1}$ \\
$4 / 30 / 1986$ & 1.26 \\
$6 / 16 / 1999$ & 6.72 \\
$6 / 16 / 2009$ & 18.52 \\
\hline
\end{tabular}

'This measurement is from the driller's well log. 
sәчวu! u!

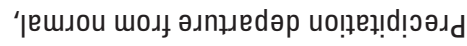

səบวu! u!

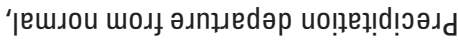

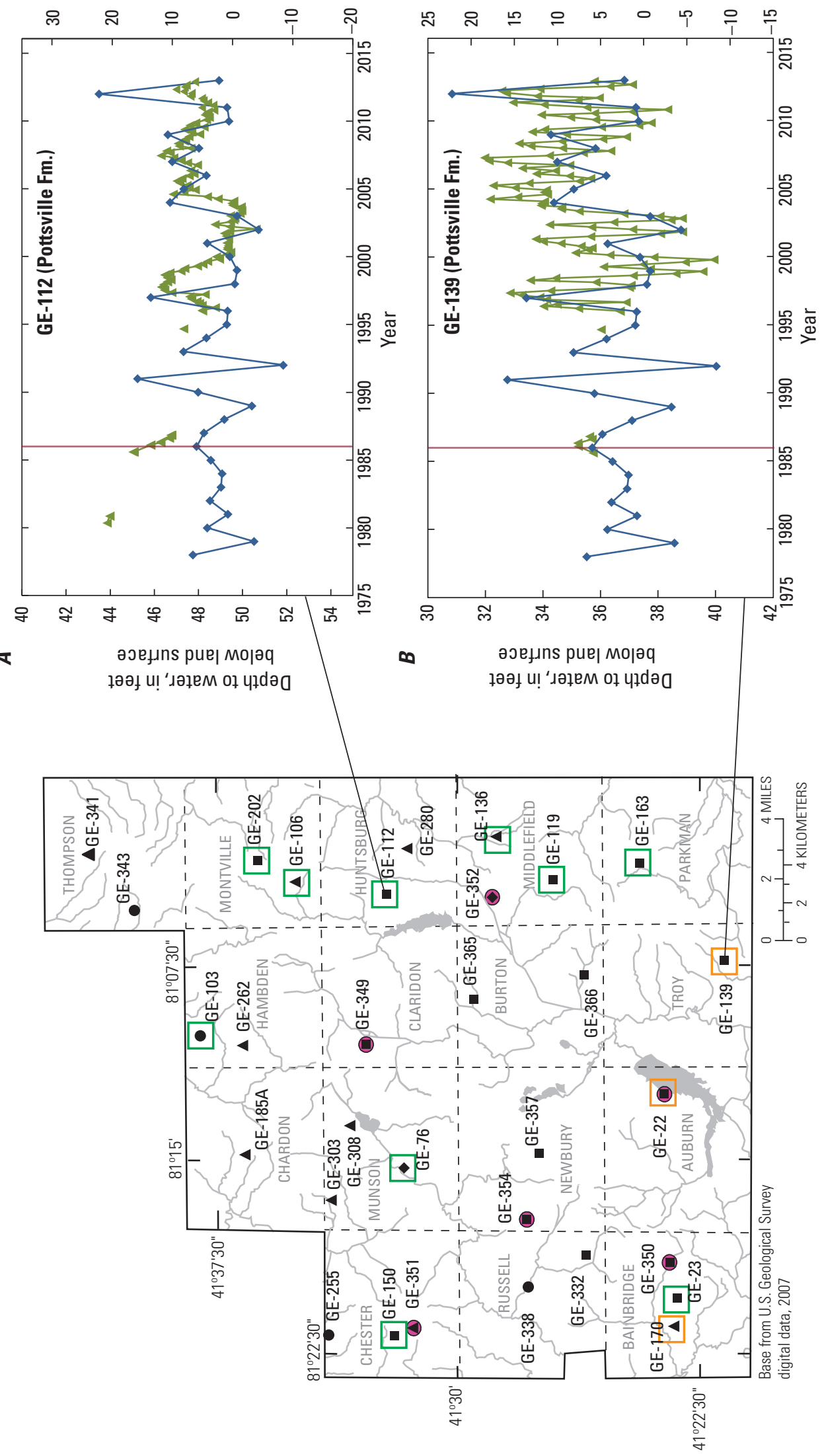

등

总证

응 궁

ฮั

$\frac{2}{\frac{\pi}{3}} \frac{1}{\frac{\pi}{2}}$

을

त्

s

음

学

옹

ำ

穴 范

\&

흐

ऐo

혼 을

응

世.

$\cong$

क

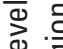

일

落

3

응

के 을

票

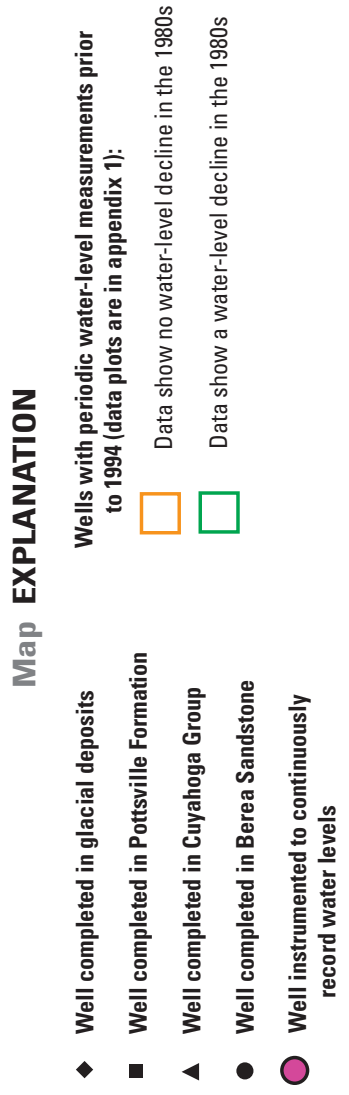

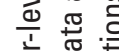

离 $\frac{\pi}{0}$

응

힝 용

호 일

可这

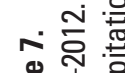

글 흘

흐ㅇㅡㅡ 옫

트늠음

홍 뭉

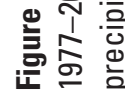




\section{Groundwater Quality in Geauga County, Ohio-Status, 2009, and Changes During 1978-2009}

\section{Septic Systems and Licensed Land Application of Septage and Biosolids}

The observed increase in population in the county has been accompanied by increasing amounts of human waste requiring treatment. Approximately 70 percent of homes in the county have household sewage systems to treat domestic sewage and wastewater (Geauga County Health District, 2010b). Most of these household systems discharge to on-lot leaching trenches, but about 19 percent of household treatment systems discharge off-lot (Mix, 2013). Point-of-sale household sewage-system inspections conducted between July 2002 and December 2012 in Geauga County (prior to transfer of property ownership) indicated that 5 percent of on-lot systems were malfunctioning and 45.8 percent of off-lot discharging systems were malfunctioning (Mix, 2013). Failing off-lot systems were generally installed prior to 1991. Failing systems can increase the risk of contaminants entering groundwater (such as viruses, intestinal bacteria, and nitrates). In addition, elevated concentrations of orthophosphate, chloride, sodium, calcium, potassium, dissolved organic carbon, boron, and sulfate, and lowered dissolved oxygen content and $\mathrm{pH}$ have been measured in shallow groundwater beneath septic systems in other parts of the United States (Katz and others, 2011).

The application of domestic septage to agricultural fields is another potential source of groundwater contamination in Geauga County. Domestic septage refers to the solids and liquids that must be periodically pumped from septic tanks to keep them in proper working condition (Ohio Environmental Protection Agency and Ohio Department of Health, 2004). The most common way to dispose of septage in Geauga County is to transport it to a municipal wastewater treatment plant (Bob Weisdack, Geauga County Health Commissioner, 2011, written commun.). However, some septage haulers land-apply their waste at two registered sites (fig. 8) (Bob Weisdack, Geauga County Health Commissioner, 2011, written commun.), which are regulated by the Geauga County Health District.

Thirty percent of the households in Geauga County receive public wastewater treatment services (Mix, 2013). Sewage from all villages and some individual subdivisions in the county is piped to wastewater treatment facilities, where processes are used to clean the wastewater and remove the solids. The treated solids, or sewage sludge, are called "biosolids" (U.S. Environmental Protection Agency, 2012). Biosolids are considered "Class A" if they are treated to a level that contains no detectible pathogens or "Class B" if detectible levels of pathogens are still present after treatment (U.S. Environmental Protection Agency, 2012). The most common way to dispose of biosolids in Ohio is to spread these organic-rich materials on agricultural fields, where they act as fertilizer to improve soils and stimulate plant growth (Ohio Environmental Protection Agency, 2006a). The fields shown in figure 8 are authorized by Ohio EPA for land application of Class B biosolids, although biosolids may never have actually been applied to a specific field. To determine whether a field has received Class B biosolids, the treatment plant to which the field is authorized must be contacted (see Ohio Environmental Protection Agency, 2010a). Regulations regarding application, monitoring, and recordkeeping are summarized by Ohio EPA and Ohio Department of Health (2004), U.S. Environmental Protection Agency (2012), and Mancl and others (1995). Detailed regulations governing the use and disposal of biosolids can be found in Code of Federal Regulations, Title 40, Part 503 (1993).

\section{Oil and Gas Drilling}

Geauga County has a long history of oil and gas drilling, with numerous existing or permitted (approved, but not yet completed) oil and gas wells (fig. 9). As of 2008, there were 1,112 wells producing oil and (or) gas, 357 plugged wells, and 535 permitted drilling sites (although 78 percent of these permits were expired) (Ohio Department of Natural Resources, 2008a). About half (48 percent) of the oil and gas wells in the county were completed in the 1980s. Drilling activities slowed down in subsequent decades, with 13.5 percent of the wells in the county completed from 1990 through January 5, 2008 (based on well completion dates in the Ohio Department of Natural Resources Oil and Gas Well Location Database (2008a). Twenty-six additional oil and gas wells were completed in the county in 2009, targeting primarily the Clinton Sandstone, with average well depths of about $4,000 \mathrm{ft}$ below land surface (Ohio Department of Natural Resources, 2010a), which is much deeper than the aquifers used for water supply.

Although the environmental risks posed by oil and gas drilling are managed through Federal and State regulations, occasionally groundwater contamination does occur, and brines, crude oil, natural gas, volatile organic compounds (VOCs), and (or) drilling fluids to leak into aquifers. The Ohio Department of Natural Resources, Division of Mineral Resources Management (ODNR-MRM) has documented 185 incidents of groundwater contamination caused by oil-field activities in Ohio from 1983 through 2007, with over half of the incidents occurring from 1983 through 1987 (Kell, 2011). The primary cause of groundwater contamination (44 percent of regulated ${ }^{1}$ incidents) has been inadequate construction or maintenance of earthen-bermed reserve pits, which are excavated adjacent to a drilling rig to hold drilling muds and fluids. ODNR-MRM investigations in the 1980s found that some pits were either unlined or had thin, easily torn liners (Kell, 2011). Prior to 1985, earthen pits also were used after drilling was completed, to store the large volumes of brine that are coproduced with oil and gas (Kell, 2011). New standards for construction of reserve pits in contamination-sensitive areas in northeastern and north-central Ohio were authorized in 1985 as part of Amended Substitute House Bill 501; this same bill eliminated produced-water earthen pits throughout the state as of July 1, 1986 (which, at the time, numbered in the thousands

\footnotetext{
${ }^{1}$ Regulated incidents are those not involving an orphaned well, which is an inactive well with no responsible party to plug the well.
} 
EXPLANATION

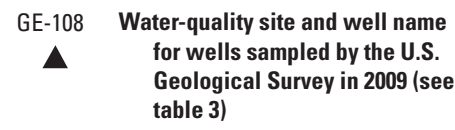

2 Public-supply well and well identifier for wells evaluated in this report (see table 4)

Fields approved for septage application

Fields approved for biosolids application
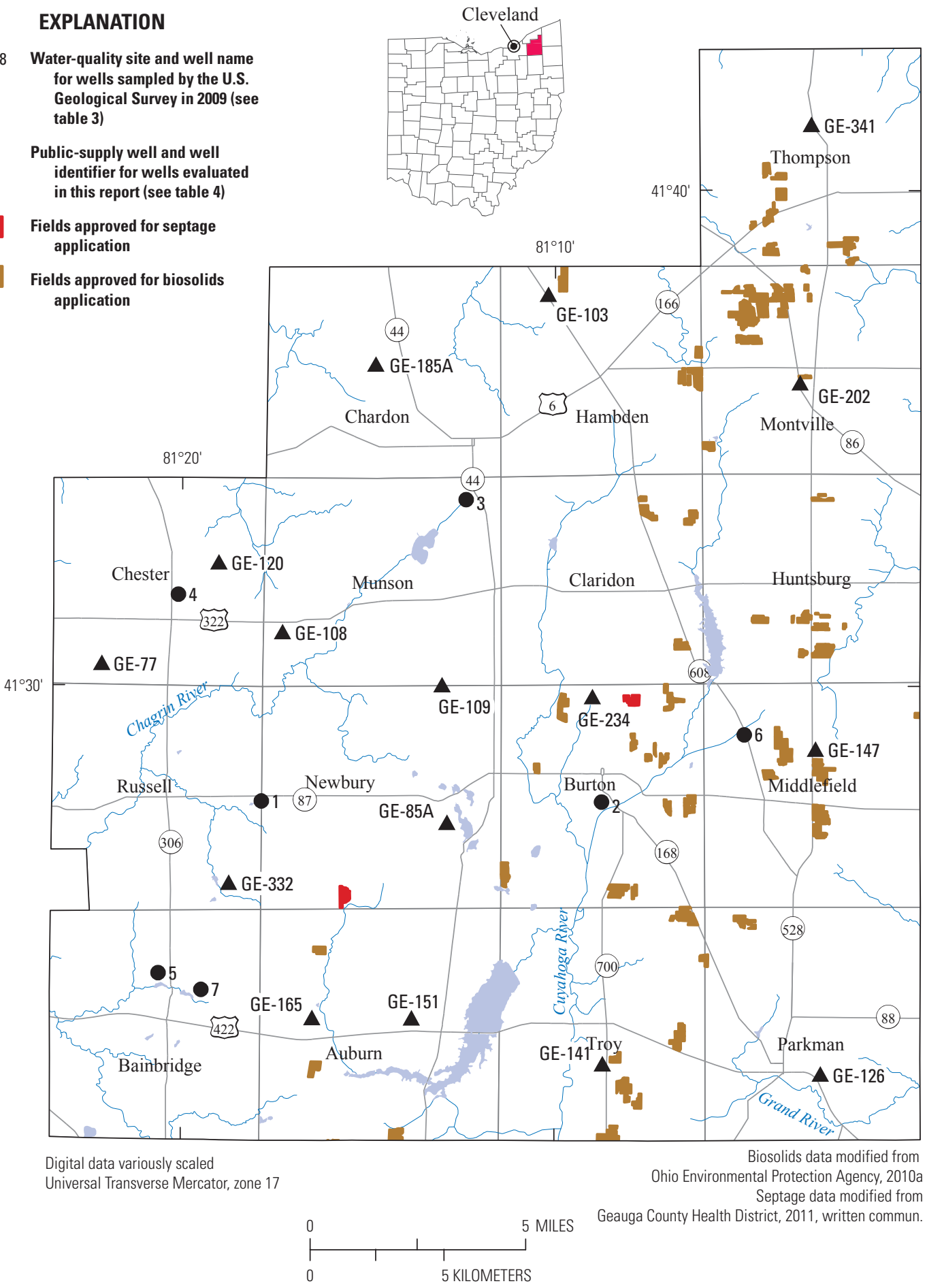

Figure 8. Authorized biosolids application sites in Geauga County, 2009, and registered septage-spreading sites, 2011. 


\section{EXPLANATION}

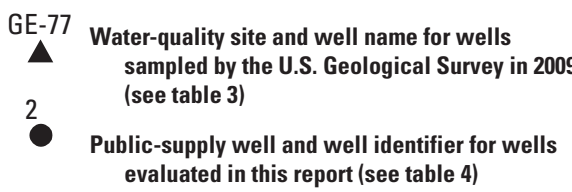
evaluated in this report (see table 4)

* Active Class II injection wells

Plugged well Permitted location Producing well
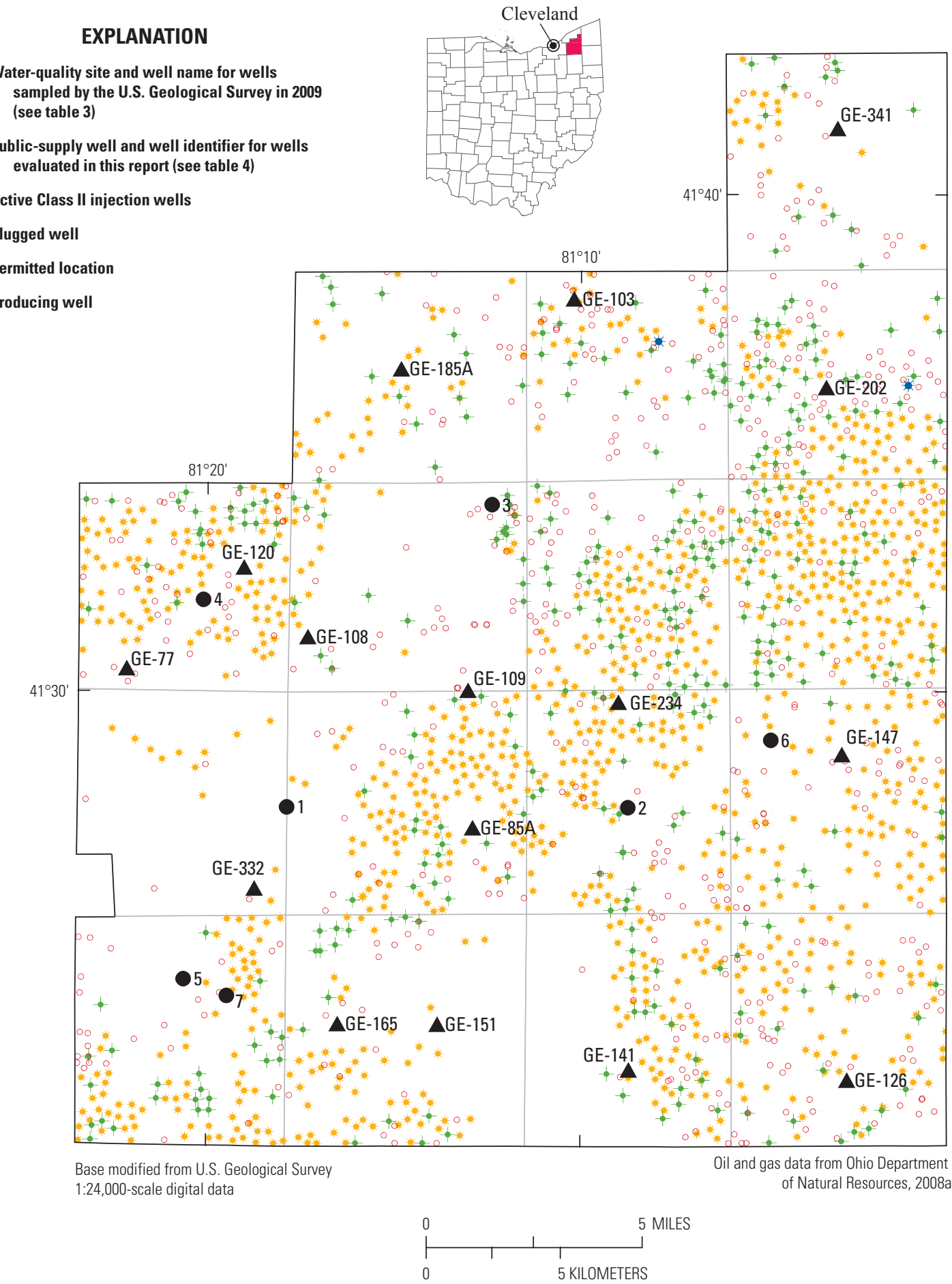

Figure 9. Oil and gas wells and active Class II injection wells in Geauga County, 2008. 
in Ohio), and established permitted Class II injection wells as the preferred method to dispose of brines.

In 2010, approximately 98 percent of oil-field fluids in Ohio were disposed of in Class II injection wells (and were stored in tanks prior to disposal), and 2 percent of oil-field fluids were spread on county, township, and village roads for dust and ice control (Tomastik, 2010). In Geauga County, only one Class II injection well, in Montville Township, was used in 2011 for brine injection. A second Class II injection well, in Hambden Township, was shut down in 2011 for "housekeeping issues" (Tom Tomastik, ODNR-MRM, written commun., 2011). Local authorities have authorized spreading of brine on roads in Auburn, Huntsburg, Middlefield, Parkman, and Thompson Townships in Geauga County (Tom Tomastik, ODNR-MRM, oral commun., 2010); this spreading is regulated by ODNR-MRM.

\section{Road Deicing}

Increasing population and development activity led to the addition of about 157 miles of roads in Geauga County between 1981 and 2008 (Geauga County Engineer's office, written commun., 2011). Most of the added roads were township roads, which increased in mileage by more than 35 percent during this period. Increased road mileage has led to greater amounts of road salt being purchased over time by the County Engineer ${ }^{2}$ for application to remove snow and ice (fig. 10). The spreading of road salt and oil-field brines on roads both have the potential to add salinity (sodium and chloride) and dissolved solids to shallow groundwater and to increase specific conductance. Calcium chloride has been used to a lesser extent than sodium chloride as a deicing chemical in Ohio (Kunze and Sroka, 2004), and also could contribute calcium to shallow groundwater.

The Ohio Department of Transportation (ODOT) has tracked its road salt use in the county since 1999 (fig. 10). These data indicate that application rates fluctuated from 1991 through 2011 but did not show an overall increase. However, ODOT services only State routes through the county, which have had consistent mileage since the $1980 \mathrm{~s}$ - it is the township roads that have increased in mileage over time as population has increased. ODOT does not spread oil-field brines on roads (Ohio Department of Transportation, written commun., 2011).

${ }^{2}$ The County Engineer purchases salt for 9 of the 16 townships in the county. Road salt purchased by Chester, Russell, Bainbridge, Auburn, Newbury, Munson, and Chardon Townships and the various municipalities in the county are not included in totals shown in figure 10.

\section{Water-Quality Issues Identified in Previous Investigations}

Jagucki and Darner (2001) summarized previous studies of groundwater quality in Geauga County done for various purposes and at various scales. These studies consistently reported that manganese and iron concentrations in groundwater in the county often exceed the aesthetically based Secondary Maximum Contaminant Levels (SMCLs) of 50 micrograms per liter $(\mu \mathrm{g} / \mathrm{L})$ and $300 \mu \mathrm{g} / \mathrm{L}$, respectively, established by the U.S. Environmental Protection Agency (USEPA; 2009) for drinking water. VOCs and indicators of road salt and, less commonly, oil-field brines have been detected in groundwater at isolated locations. Nitrate concentrations in groundwater at some locations have been indicative of the effects of fertilizer application or effluent from septic systems, but concentrations have not exceeded the health-based USEPA Maximum Contaminant Level (MCL) of 10 milligrams per liter $(\mathrm{mg} / \mathrm{L})$ as nitrogen $(\mathrm{N})$.

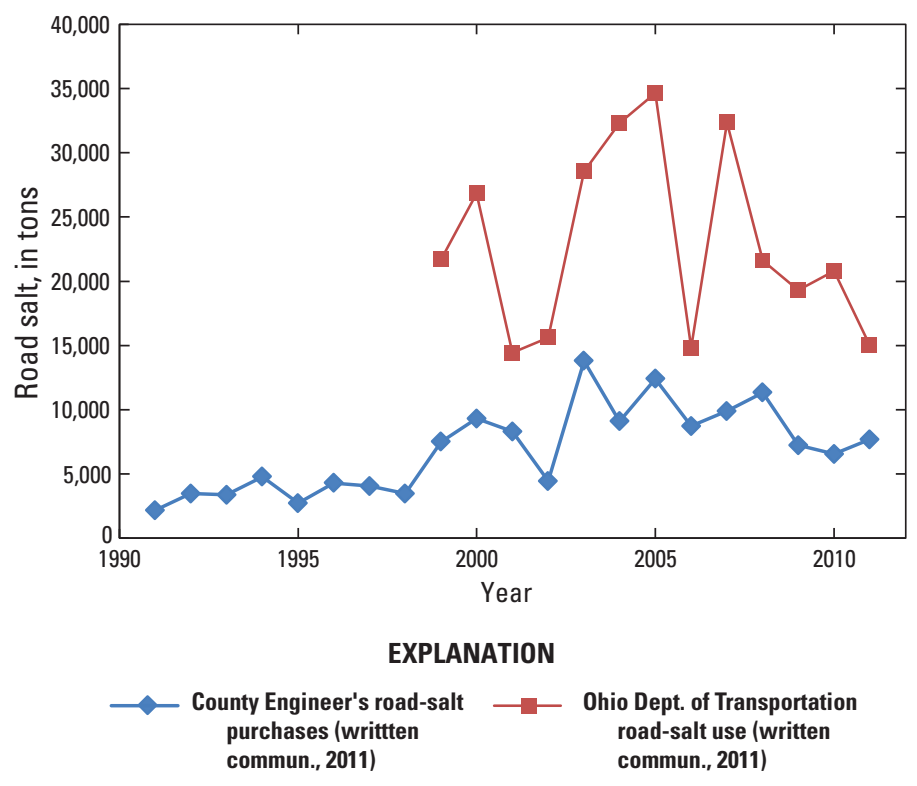

Figure 10. Road-salt use in Geauga County, Ohio, 1991-2011. 


\section{Groundwater Quality in Geauga County, Ohio-Status, 2009, and Changes During 1978-2009}

\section{Groundwater Affected by Localized Chemical and Gas Releases}

Multiple entities investigate complaints of groundwater affected by commercial and industrial activities, including Ohio EPA Division of Environmental Response and Revitalization (DERR), Ohio EPA Division of Drinking and Ground Waters, the Geauga County Health District (which investigates complaints by domestic well owners), and ODNR-MRM (which examines complaints of contamination related to oil and gas drilling). Sites in Geauga County for which the authors obtained agency documentation that groundwater has been affected by localized chemical and gas releases are shown in figure 11 and summarized below. Additional sites may exist. The aquifer or aquifers affected at each site are specified in the following summaries, if that information was documented by the investigating agency.

Jagucki and Darner (2001) examined the files of Ohio EPA DERR and found four principal sites of documented groundwater contamination in Geauga County between 1984 and 1996 (fig. 11, sites 1-4). At sites 1 and 2 in Bainbridge Township, the Pottsville Formation and the Berea Sandstone were contaminated with VOCs such as trichloroethene (TCE), 1,1,1-trichloroethane (TCA), perchloroethene (PCE), and benzene. Groundwater at site 3 in Bainbridge Township contained TCA and benzene, plus diethyl ether and 1,2-dichloroethane (DCA). Water lines were extended from Cuyahoga County to provide municipal drinking water for residents at these sites in response to the contamination. Groundwater in both the Pottsville Formation and the Berea Sandstone at site 4 in Chester Township was contaminated with gasoline compounds. In addition, high chloride concentrations in groundwater at site 4 were attributed to road salt. As a result, leaking underground storage tanks were removed or replaced, and road-salt storage piles in this area were underlain with asphalt and covered with an enclosure. Details of the investigations at sites 1 through 4 are summarized by Jagucki and Darner (2001).

Descriptions of groundwater contamination at sites 5 through 8 (fig. 11) were obtained from a database of sites investigated by Ohio EPA, Division of Drinking and Ground Waters (2010b) (referred to as the "Groundwater Impacts Database"). The source of VOC contamination at site 5 was a chemical spill which occurred in 1980 in Russell Township. Groundwater samples collected from wells in the Pottsville Formation from 1986 to 2006 contained VOCs including cis1,2-dichloroethene at a concentration 4 times the MCL, and TCE and vinyl chloride at concentrations more than 50 times MCL. The primary means of remediation has been natural attenuation (Ohio Environmental Protection Agency, 2010b).

Investigations that began in 1994 at an industrial site near the south edge of the Village of Middlefield (fig. 11, site 6) identified two distinct plumes of contamination in the Pottsville Formation. Contaminants were primarily chlorinated solvents, including TCE, PCE, TCA, DCA, and 1,2-dichloroethene (DCE). Contamination was also detected in two offsite residential wells and one nearby commercial well in 2001. Both residences were connected to the Middlefield public water supply in 2001 (U.S. Department of Health and Human Services, 2004). A pump and treat system consisting of two extraction wells was installed in 2002 to reduce the levels and extent of contamination.

Groundwater contamination at site 7 (fig. 11) was investigated in 2001 in Parkman Township, in the southeastern corner of the county. Leaking underground storage tanks were determined to be the source of benzene to shallow groundwater in glacial deposits overlying the Pottsville Formation at this location. Contamination was found to have moved offsite, and one public-supply well to the east was affected. Monitoring wells were installed, and the maximum benzene concentration found was $432 \mu \mathrm{g} / \mathrm{L}$, greatly exceeding the MCL of $5 \mu \mathrm{g} / \mathrm{L}$. Primary remediation has been fluid and vapor extraction (Ohio Environmental Protection Agency, 2010b).

Ohio EPA sampled groundwater beneath a mixed industrial and commercial facility in Newbury Township from 2005 to 2008 (fig. 11, site 8). Anaylses detected chromium, lead, and five VOCs (cis-1,2-dichloroethene, TCE, DCA, 1,2-dichloroethane, and vinyl chloride) in the glacial deposits but not in the underlying Pottsville Formation. Aboveground storage tanks, ponds, and a dumping area were determined to be the source of contamination. Removal of contaminated sediments was the primary means of remediation (Ohio Environmental Protection Agency, 2010b).

A completed oil and gas well in Bainbridge Township was determined by ODNR-MRM (2008b) to be the source of a natural gas invasion to the Pottsville Formation, Cuyahoga Formation, and Berea Sandstone aquifers that occurred on December 2007 (fig. 11, site 9). Natural gas migrated from the aquifers into homes by way of water wells in basements (either unvented, in-use wells or abandoned but unplugged wells), causing one home to explode and 19 to be evacuated. Beginning in February 2008, water samples were collected and analyzed from 79 water wells. Natural gas was found in 23 water wells (22 private and one public-supply well). The highest concentration of dissolved methane found was $1.04 \mathrm{mg} / \mathrm{L}$. On the basis of a review of water-quality data, ODNR-MRM determined that groundwater had not been affected by oil-field brine, crude oil, or hydrofracture fluids. ODNR-MRM also noted that there was inadequate evidence to conclude that natural gas migrating through the aquifers had changed inorganic groundwater quality or had resulted in contamination of public water supplies (Ohio Department of Natural Resources, 2008b).

An investigation by Ohio EPA of 14 domestic wells near the road-salt storage site on Mentor Road northwest from the City of Chardon (fig. 11, site 10) indicated that 9 wells in the area had been affected by road salt, on the basis of ratios of chloride to bromide found in groundwater from these wells. The road salt had been stored in a covered area, but cinders and salt had been mixed on a pervious surface for several years. Three of the homes had chloride concentrations in their wells in excess of the SMCL of $250 \mathrm{mg} / \mathrm{L}$ (Koziol, 2010). 


\section{EXPLANATION}

Site of documented groundwater contamination (location approximate) and site number as referred to in text

GE-77 Water-quality site and well name for wells

- sampled by the U.S. Geological Survey in 2009 (see table 3)

2 Public-supply well and well identifier for wells evaluated in this report (see table 4)
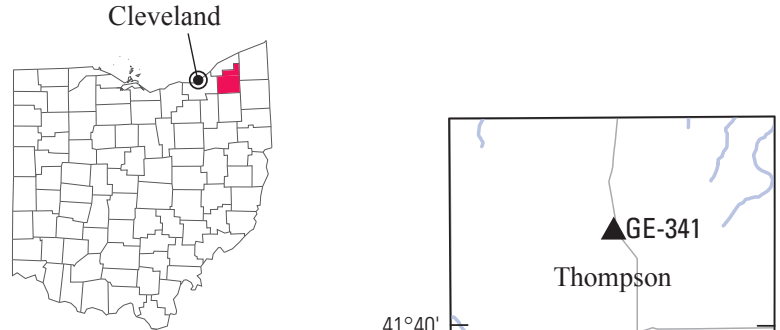

Thompson

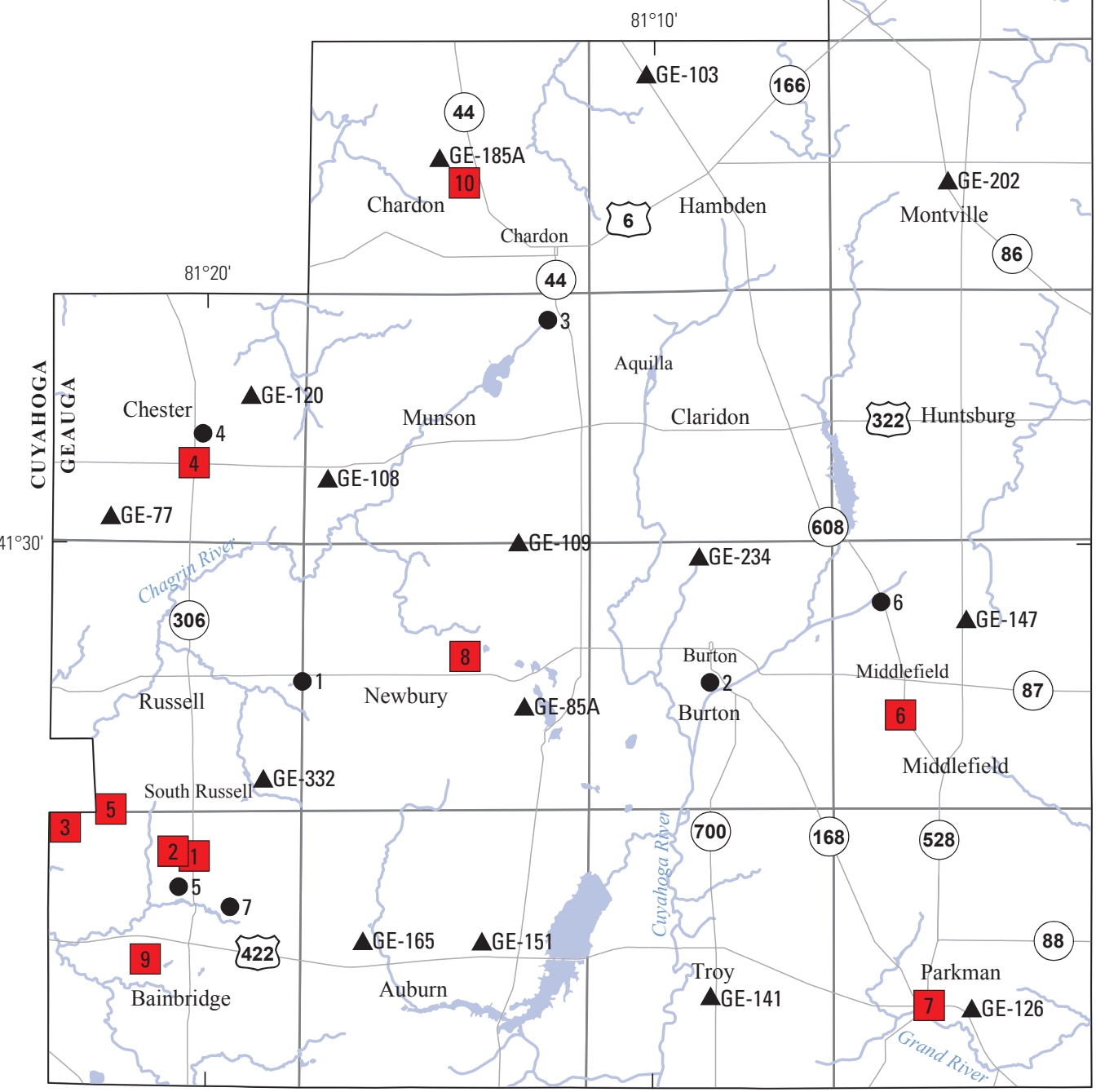

Base modified from U.S. Geological Survey 1:24,000-scale digital data

Contamination location data from Ohio Environmental Protection Agency, Division of Drinking and Ground Waters, 2010b Ohio Environmental Protection Agency, Division of 5 MILES Environmental Response and Revitalization, 2012a.

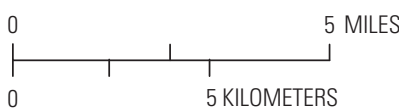

Figure 11. Approximate location of sites in Geauga County, Ohio, where human effects on groundwater from industrial or commercial point sources have been documented. 


\section{Methods of Study}

\section{Well Selection, Water-Quality Sampling Procedures, and Laboratory Analysis}

To examine groundwater-quality conditions in 2009 , the USGS sampled 16 wells from June 9 through June 19, 2009. Well locations are shown as green symbols in figure 12, latitudes and longitudes are given in appendix table 4-1, and well characteristics and constituents analyzed for are summarized in table 3. Fourteen of the sampled wells were domestic wells. Two wells were owned by very small public suppliers (defined as purveyors serving $25-500$ people). These two wells provide water for a church (GE-341) and a golf course clubhouse (GE-85A). For simplicity, all 16 wells will be referred to as "domestic wells" in following text. The following criteria were used in selecting wells for USGS sampling:

1. Previous samples.-Efforts were made to resample wells from which the USGS collected water-quality data in both 1986 (Eberts and others, 1990) and 1999 (Jagucki and Darner, 2001) so that temporal changes in water quality could be assessed from a consistent set of wells. All 16 wells sampled in 2009 also were sampled in 1999, and 11 of the 16 wells also were sampled in 1986 (table 3). Two wells had been consistently sampled since 1980 .

2. Spatial distribution.-Wells were selected to provide broad spatial distribution within the county.

3. Stratigraphic distribution.-Wells completed in each of the primary stratigraphic units (fig. 2) were sampled in the quantities indicated: 3 in the glacial deposits, 5 in the Pottsville Formation, 5 in the Cuyahoga Group, and 3 in the Berea Sandstone. Only wells completed in a single stratigraphic unit were selected.

4. Likelihood of being affected by human activities.Although the first three criteria were emphasized during well selection, most of the wells available for sampling in both 1986 and 1999 were relatively deep wells in areas of low population density. Thus, efforts were made to select some wells that were likely to provide early detection of water-quality changes resulting from human activities at land surface. Desired characteristics were a shallow well depth or top of open interval that was within about $25 \mathrm{ft}$ of the water table, young water (water in which tritium was detected in 1999, which is indicative of aquifer recharge that occurred since 1953), and a location in an area of relatively high population density or rapid population growth.

5. Ability to produce representative samples.-Final well selection was based upon an inspection of the well construction and plumbing system at each well to ensure that a representative sample of groundwater could be obtained.
Samples were collected by means of methods described in the "National Field Manual for the Collection of WaterQuality Data" (U.S. Geological Survey, 1997-present) and the "Quality-Assurance Plan for Water-Quality Activities in the USGS Ohio Water Science Center" (Francy and Shaffer, 2008). Samples were collected from household spigots; existing plumbing fixtures and well pumps were used. Well owners identified spigots that provided untreated water. USGS personnel were able to inspect the plumbing at 7 of the 16 sites to verify that water from the spigots was untreated. It was possible to bypass the pressure tank for sampling at only two of the sites (GE-85A and GE-234, fig. 12, table 3). Ancillary data (such as distance of the well from the nearest road, age of septic system, frequency of septic tank pumping, use of well water, and land use) also were collected.

After arriving at the site, the field crew attached clean tubing to the sampling spigot and then connected the tubing to a flow manifold. Flow was diverted to a flowthrough chamber attached to a multiparameter sonde for measurement of $\mathrm{pH}$, specific conductance, temperature, and dissolved oxygen. Turbidity was measured by using a separate turbidimeter. Even though all wells were in regular use, at least one well volume of water was purged before sampling to remove standing water from the well bore, pressure tank, and pipes and to ensure that samples reflected the chemistry of the water in the aquifer. Purging also served to condition the sampling equipment with well water. Sampling did not begin until sequential fieldmeasurement values met stabilization criteria described in the "National Field Manual for the Collection of Water-Quality Data" (U.S. Geological Survey, 1997-present, table 6.0-1).

Before sampling, flow rate through the sampling line was reduced to 0.1 gallon per minute, leaving discharge through the other lines at the purge rate. The water was allowed to discharge at the purge rate to keep the pump from cycling off after the pressure tank was filled and to reduce the chance of backflow of water in adjacent plumbing lines.

All groundwater samples were analyzed for alkalinity, specific conductance, $\mathrm{pH}$, temperature, dissolved oxygen, turbidity, total sulfide, combustible gas, dissolved major and minor ions (including iron, manganese and bromide), dissolved arsenic, total dissolved solids, dissolved nutrients, dissolved pesticides, total coliform bacteria, and Escherichia coli (E. coli) bacteria. Fecal coliform and fecal streptococci bacteria also were analyzed for at wells previously sampled in 1986 and in other selected wells. The dissolved trace elements cadmium, chromium, copper, lead, selenium, and zinc were analyzed for at four wells - one well from each of the four aquifers (table 3). On the basis of presence of flammable gas in sample headspace, water samples from three wells were analyzed for dissolved gases (table 3). Finally, two samples from wells tapping the Berea Sandstone were analyzed for tritium to augment tritium data collected in 1999.

Analyses for alkalinity, specific conductance, $\mathrm{pH}$, temperature, dissolved oxygen, turbidity, sulfide and bacteria were done onsite by means of standard techniques described in the "National Field Manual for the Collection of Water-Quality 


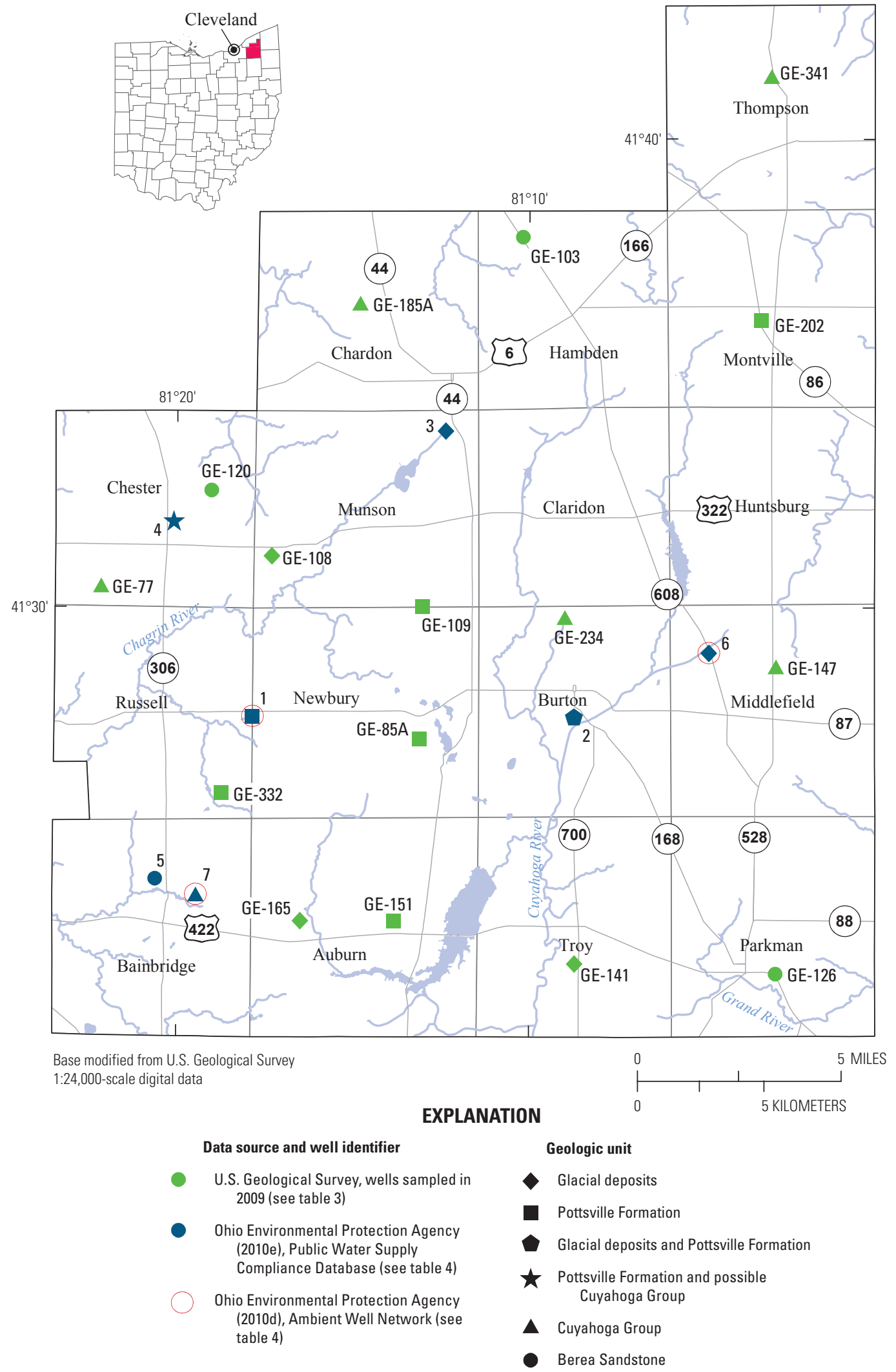

Figure 12. Data source and geologic unit of wells used to evaluate suitability of water for drinking, Geauga County, Ohio. 


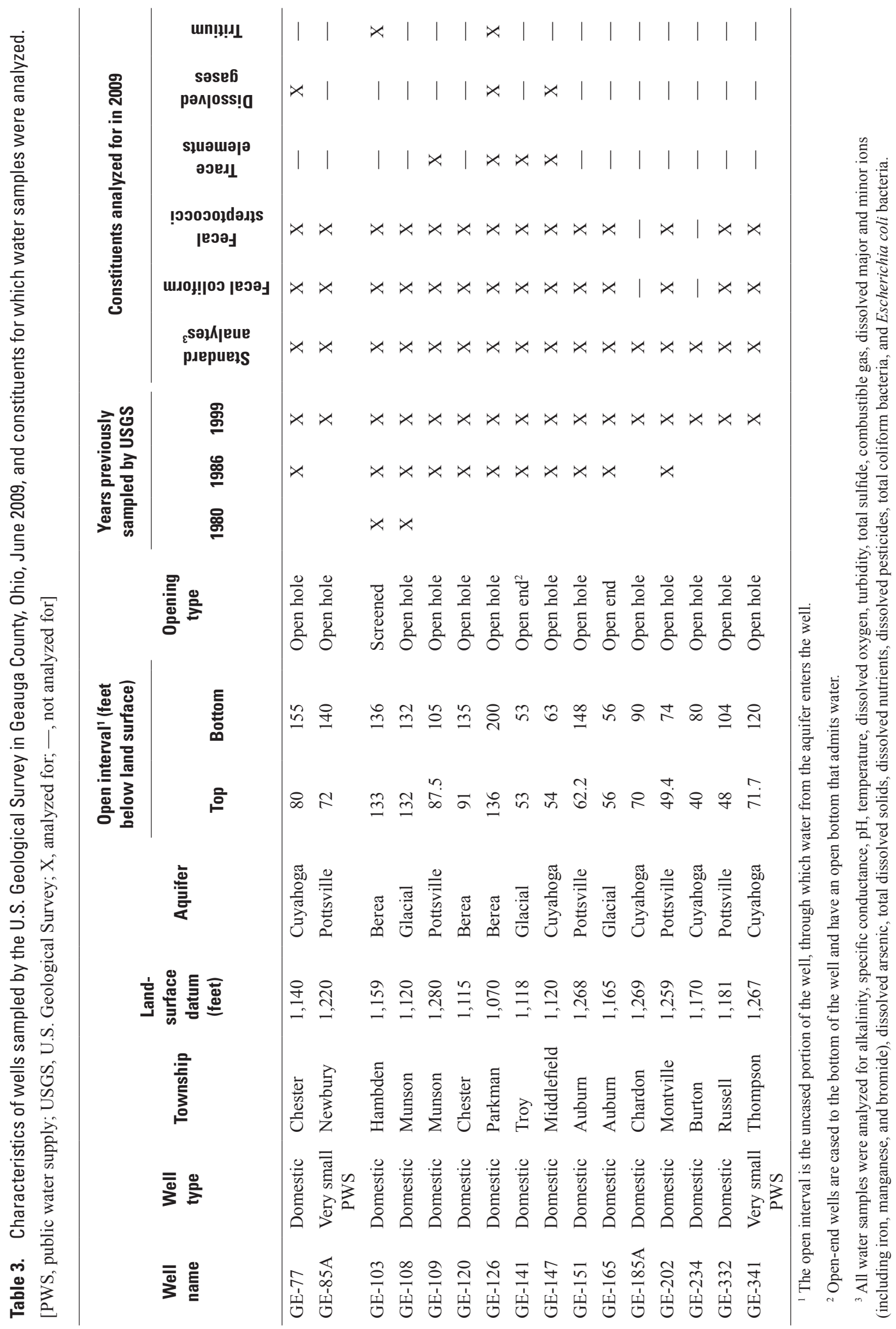


Data" (U.S. Geological Survey, 1997-present). Water from each of the wells was screened for combustible-gas fraction at the wellhead and on the headspace of water samples. To measure combustible-gas fraction at the wellhead, the well cap was loosened and the tip of a combustible-gas indicator calibrated to 2 percent methane gas was inserted into the gap between the cap and well casing. To measure combustible-gas fraction in the headspace of water samples, the gas indicator was connected to a headspace chamber according to methods described by Chafin and others (1996, p. 9). The minimum reporting level (smallest concentration that can be reliably measured) of this screening method is 0.1 percent volume of combustible gas in the headspace. If combustible gas was detected at either the wellhead or in the headspace of a water sample, a groundwater sample was collected and sent to the USGS Chlorofluorocarbon Laboratory in Reston, Virginia, for analysis of dissolved gases (http://water.usgs.gov/lab/ dissolved-gas/).

Tritium samples were analyzed by the USGS Tritium Laboratory in Menlo Park, California. Analyses for all other constituents were done by the USGS National Water Quality Laboratory (NWQL) in Denver, Colorado. The NWQL generally censored analytical results to the laboratory reporting level (LRL), as defined by Oblinger Childress and others (1999). Nondetections were reported as less than the LRL. Concentrations measured between the LRL and the long-term method detection level (Oblinger Childress and others, 1999) were reported as estimated concentrations. In this report, an estimated concentration is referred to as a "trace amount" of the constituent.

Sample tubing and equipment were decontaminated after sampling at each well site as per standard methods (U.S. Geological Survey, 1997-present). Bacteria equipment was sterilized by autoclaving. Quality-control samples were collected at the rate of 10 percent to ensure sample integrity and final quality of data, as specified in the "Quality-Assurance Plan for Water-Quality Activities in the USGS Ohio Water Science Center" (Francy and Shaffer, 2008). Variability introduced by sample collection and laboratory analyses (represented by replicate samples) was compared to variability in constituent concentration between years. Types of quality-control samples and the method and frequency of collection are discussed in more detail in appendix 2.

\section{Public-Supply Well Data From the Ohio Environmental Protection Agency}

Because many of the wells sampled by the USGS in 2009 are in areas of relatively low population (fig. 5), water-quality data from 2000-2010 for selected public-supply well fields were obtained from Ohio EPA and used to evaluate recent water-quality conditions in more populated and developed areas where groundwater is more likely to be affected by human activities. Of almost 400 public-supply wells in the county, data from seven well-field locations were selected (fig. 12). These seven public-supply well fields were chosen on the basis of (1) availability of untreated water samples, (2) well fields serving the largest incorporated areas, and (3) well fields located in the more developed, western townships. Analyses of untreated water samples were preferred because the goal of this study is to evaluate the quality of the groundwater in the aquifers (source water) rather than exposure at the tap. Of the seven well fields chosen for evaluation, analyses of untreated water were available for the three well fields that are included in Ohio EPA's Ambient Well Network (2010d): ASM International, Middlefield Village, and Tanglewood Lake (table 4, fig. 12). For the other four well fields evaluated in this report (table 4, fig. 12), water-quality data for treated samples and occasionally for untreated samples were obtained from Ohio EPA's Safe Drinking Water Information System database (2010e), which contains all water-quality data submitted to Ohio EPA Division of Drinking and Ground Waters by Ohio public water systems and their certified laboratories to comply with legal monitoring requirements under the Safe Drinking Water Act (referred to in this report as "compliance data"). The only compliance data evaluated were those representing (a) water that was untreated or (b) water that was treated by a method that does not effectively remove the constituent of interest (unpublished data on file at the USGS Ohio Water Science Center, Columbus).

Physical characteristics of public-supply well fields considered in this report are listed in table 4, along with the Ohio EPA database from which water-quality results were obtained, and available chemical analyses. Note that most samples from Ohio EPA's compliance database represent water from more than one well blended together prior to analysis (with the exception of samples from Christ Presbyterian Church, table 4); samples of untreated water from Ohio EPA's Ambient Ground Water Monitoring program represent water produced by a single well. All public-supply well samples were analyzed for total concentrations of a constituent (dissolved plus particulate).

\section{Evaluation of the Effect of Land Cover and Population Characteristics on Water Quality}

To evaluate the effects of nearby land cover and population on groundwater quality in 2009 , a circle with a radius of 500 meters $(\mathrm{m})(1,640 \mathrm{ft})$ was created around each of the 16 domestic wells sampled in 2009 and the 7 public-supply wells considered in this report. Because the regional direction of groundwater flow was known near each well (Jagucki and Lesney, 1995), it was possible to further refine the land area most likely to affect the quality of water captured by each well by converting each circle into a single quarter-circle segment and rotating it toward the upgradient direction (fig. 13), as described by Ator and Denis (1997) and Button (2003). Land-cover data within the quarter circle were then extracted (appendix table 3-1), along with population data described below. Land-cover data were from the 2001 National Land 


\section{Groundwater Quality in Geauga County, Ohio-Status, 2009, and Changes During 1978-2009}

Table 4. Physical characteristics of public-supply well fields considered in this report and analyses available, Geauga County, Ohio, 2000-2010.

[Ohio EPA, Ohio Environmental Protection Agency; Fm., Formation; Na, sodium; Cl, chloride; Fl, fluoride; $\mathrm{SO}_{4}$, sulfate; $\mathrm{TDS}$, total dissolved solids; $\mathrm{NH}_{3}$, ammonia; $\mathrm{NO}_{3}$, nitrate; $\mathrm{NO}_{2}$, nitrite; As, arsenic; $\mathrm{Cd}$, cadmium; Cr, chromium; $\mathrm{Cu}$, copper; Fe, iron; $\mathrm{Pb}$, lead; Mn, manganese; Se, selenium; $\mathrm{Zn}$, zinc; $\mathrm{VOCs}$, volatile organic compounds; - , not available; $\mathrm{U}$, untreated water analyzed; T, treated water analyzed; $\mathrm{U}+\mathrm{T}$, both treated and untreated samples analyzed. Data compiled from Ohio Environmental Protection Agency's (2010c) drinking water source assessment reports for each well, Ohio Environmental Protection Agency's Ambient Groundwater Monitoring Program database (2010d) and Safe Water Information System database (2010e), and Ohio Department of Natural Resources water withdrawal registration program database (2010b). Approximate well locations are shown in fig. 12.]

\begin{tabular}{|c|c|c|c|c|c|c|c|c|c|}
\hline \multirow{3}{*}{$\begin{array}{c}\text { Well } \\
\text { identifier } \\
\text { (for } \\
\text { report } \\
\text { purposes) } \\
\\
1\end{array}$} & \multirow{3}{*}{$\begin{array}{c}\text { Name of } \\
\text { public-supply } \\
\text { well field }\end{array}$} & \multirow{3}{*}{$\begin{array}{l}\text { Township } \\
\\
\text { Russell }\end{array}$} & \multirow{3}{*}{$\begin{array}{c}\text { Ohio } \\
\text { EPA } \\
\text { data } \\
\text { source } \\
\\
\\
\text { Ambient } \\
\text { network }\end{array}$} & \multirow{3}{*}{$\begin{array}{c}\begin{array}{c}\text { Number } \\
\text { of wells } \\
\text { in }\end{array} \\
\text { wellfield }\end{array}$} & \multirow{3}{*}{$\begin{array}{c}\begin{array}{c}\text { Number } \\
\text { of } \\
\text { wells }\end{array} \\
\text { sampled } \\
\text { for this } \\
\text { report } \\
\text { unless } \\
\text { noted } \\
\text { otherwise } \\
1\end{array}$} & \multirow{3}{*}{$\begin{array}{l}\text { Aquifer } \\
\\
\text { ottsville } \\
\text { Fm. }\end{array}$} & \multirow{3}{*}{$\begin{array}{l}\text { Total } \\
\text { pumping } \\
\text { rate, in } \\
\text { gallons } \\
\text { per day } \\
2,040\end{array}$} & \multicolumn{2}{|c|}{$\begin{array}{l}\text { Open interval of } \\
\text { sampled wells, } \\
\text { in feet below } \\
\text { land surface }^{1}\end{array}$} \\
\hline & & & & & & & & Top & Bottom \\
\hline & & & & & & & & 88 & 138 \\
\hline 2 & Burton Village & Burton & $\begin{array}{l}\text { Compliance } \\
\text { data }^{2}\end{array}$ & 2 & 2 & $\begin{array}{l}\text { Pottsville } \\
\text { Fm., glacial } \\
\text { deposits }\end{array}$ & 165,000 & $50-90$ & $65-120$ \\
\hline 3 & Chardon City & Munson & $\begin{array}{l}\text { Compliance } \\
\text { data }\end{array}$ & 6 & 6 & $\begin{array}{l}\text { Glacial } \\
\text { deposits }\end{array}$ & 646,080 & $105-144$ & - \\
\hline 4 & $\begin{array}{c}\text { Christ Pres- } \\
\text { byterian } \\
\text { Church }\end{array}$ & Chester & $\begin{array}{l}\text { Compliance } \\
\text { data }\end{array}$ & 1 & 1 & $\begin{array}{l}\text { Pottsville } \\
\text { Fm. and } \\
\text { Cuyahoga } \\
\text { Group }\end{array}$ & 620 & - & 130 \\
\hline 5 & Lake Lucerne & Bainbridge & $\begin{array}{l}\text { Compliance } \\
\text { data }\end{array}$ & 14 & 14 & $\begin{array}{l}\text { Berea } \\
\text { Sandstone }\end{array}$ & 145,280 & $25-55$ & $80-305$ \\
\hline 6 & $\begin{array}{l}\text { Middlefield } \\
\text { Village }\end{array}$ & Middlefield & $\begin{array}{l}\text { Ambient } \\
\text { network }^{3}\end{array}$ & 2 & 1 & $\begin{array}{l}\text { Glacial } \\
\text { deposits }\end{array}$ & 385,000 & 90 & 104 \\
\hline 7 & $\begin{array}{l}\text { Tanglewood } \\
\text { Lake }\end{array}$ & Bainbridge & $\begin{array}{l}\text { Ambient } \\
\text { network }^{3}\end{array}$ & 8 & 1 & $\begin{array}{c}\text { Cuyahoga } \\
\text { Group }\end{array}$ & 295,000 & 43 & 159 \\
\hline
\end{tabular}

${ }^{1}$ The open interval is the uncased portion of the well, through which water from the aquifer(s) enters the well. A range of depths is shown for the top and bottom of the open interval if sampled water was a blend of water from more than one well.

${ }^{2}$ Compliance data are analytical results submitted to Ohio EPA Division of Drinking and Ground Waters by Ohio public water systems and their certified laboratories to comply with legal monitoring requirements under the Safe Drinking Water Act. These data are stored in the Ohio EPA's Safe Water Information System database. Samples may be either untreated or treated, and, with the exception of samples from Christ Presbyterian Church, represent a blend of water from multiple wells in the well field.

${ }^{3}$ Most chemical analyses considered for this well field are from Ohio EPA's Ambient Groundwater Monitoring Network and are samples of untreated water from a single well. Compliance data were also obtained for this well field, but were only used when the samples from the Ambient Network well were not analyzed for a constituent of interest. When compliance data were used, the sample may be treated or untreated water and represents a blend of water from all wells in the well field. 
Table 4. Physical characteristics of public-supply well fields considered in this report and analyses available, Geauga County, Ohio, 2000-2010.-Continued

[Ohio EPA, Ohio Environmental Protection Agency; Fm., Formation; Na, sodium; Cl, chloride; Fl, fluoride; $\mathrm{SO}_{4}$, sulfate; TDS, total dissolved solids; $\mathrm{NH}_{3}$, ammonia; $\mathrm{NO}_{3}$, nitrate; $\mathrm{NO}_{2}$, nitrite; As, arsenic; Cd, cadmium; Cr, chromium; Cu, copper; Fe, iron; Pb, lead; Mn, manganese; Se, selenium; Zn, zinc; VOCs, volatile organic compounds; - , not available; $\mathrm{U}$, untreated water analyzed; T, treated water analyzed; U+T, both treated and untreated samples analyzed. Data compiled from Ohio Environmental Protection Agency's (2010c) drinking water source assessment reports for each well, Ohio Environmental Protection Agency's Ambient Groundwater Monitoring Program database (2010d) and Safe Water Information System database (2010e), and Ohio Department of Natural Resources water withdrawal registration program database (2010b). Approximate well locations are shown in fig. 12.]

\begin{tabular}{|c|c|c|c|c|c|c|c|c|c|c|c|c|c|c|c|c|c|c|c|c|}
\hline \multirow{2}{*}{$\begin{array}{c}\text { Well } \\
\text { identifier } \\
\text { (for } \\
\text { report } \\
\text { purposes) }\end{array}$} & \multicolumn{20}{|c|}{ Chemical analyses available, 2000-2010 } \\
\hline & $\mathrm{pH}$ & $\mathrm{Na}$ & CI & FI & $\mathrm{SO}_{4}$ & TDS & $\mathrm{NH}_{3}$ & $\mathrm{NO}_{3}$ & $\mathrm{NO}_{2}$ & As & Cd & $\mathrm{Cr}$ & $\mathrm{Cu}$ & $\mathrm{Fe}$ & $\mathrm{Pb}$ & Mn & Se & $\mathrm{Zn}$ & $\begin{array}{l}\text { Pesti- } \\
\text { cides }\end{array}$ & VOCs \\
\hline 1 & $\mathrm{U}$ & $\mathrm{U}$ & $\mathrm{U}$ & $\mathrm{U}$ & $\mathrm{U}$ & $\mathrm{U}$ & $\mathrm{U}$ & $\mathrm{U}$ & - & $\mathrm{U}$ & $\mathrm{U}$ & $\mathrm{U}$ & $\mathrm{U}$ & $\mathrm{U}$ & $\mathrm{U}$ & $\mathrm{U}$ & $\mathrm{U}$ & $\mathrm{U}$ & - & $\mathrm{U}$ \\
\hline 2 & - & - & - & - & - & - & - & $\mathrm{T}^{4}$ & $\mathrm{~T}^{4}$ & $\mathrm{~T}^{4}$ & - & - & - & - & - & - & - & - & $\mathrm{T}^{4}$ & $\mathrm{~T}^{4}$ \\
\hline 3 & - & - & - & - & - & - & - & $\mathrm{T}^{4}$ & $\mathrm{~T}^{4}$ & $\mathrm{~T}^{4}$ & - & - & - & - & - & - & - & - & $\mathrm{T}^{4}$ & $\mathrm{~T}^{4}$ \\
\hline 5 & - & $\mathrm{U}^{4}$ & - & $\mathrm{U}^{4}$ & $\mathrm{U}^{4}$ & $\mathrm{U}^{4}$ & - & $\mathrm{T}^{4}$ & $\mathrm{U}^{4}+\mathrm{T}^{4}$ & $\mathrm{U}^{4}+\mathrm{T}^{4}$ & $\mathrm{U}^{4}$ & $\mathrm{U}^{4}$ & $\mathrm{U}^{4}$ & $\mathrm{U}^{4}$ & $\mathrm{U}^{4}$ & $\mathrm{U}^{4}$ & $\mathrm{U}^{4}$ & - & $\mathrm{U}^{4}+\mathrm{T}^{4}$ & $\mathrm{U}^{4}+\mathrm{T}^{4}$ \\
\hline 6 & $\mathrm{U}$ & $\mathrm{U}$ & $\mathrm{U}$ & $\mathrm{U}$ & $\mathrm{U}^{4}$ & $\mathrm{U}^{4}$ & - & $\mathrm{T}^{4}$ & $\mathrm{U}^{4}+\mathrm{T}^{4}$ & $\mathrm{U}+\mathrm{T}^{4}$ & $\mathrm{U}$ & $\mathrm{U}$ & $\mathrm{U}$ & $\mathrm{U}$ & $\mathrm{U}$ & $\mathrm{U}$ & $\mathrm{U}$ & $\mathrm{U}$ & $\mathrm{U}^{4}+\mathrm{T}^{4}$ & $\mathrm{U}^{4}+\mathrm{T}^{4}$ \\
\hline 7 & $\mathrm{U}$ & $\mathrm{U}$ & $\mathrm{U}$ & $\mathrm{U}$ & $\mathrm{U}^{4}$ & - & - & $\mathrm{T}^{4}$ & $\mathrm{U}^{4}+\mathrm{T}^{4}$ & $\mathrm{U}$ & $\mathrm{U}$ & $\mathrm{U}$ & $\mathrm{U}$ & $\mathrm{U}$ & $\mathrm{U}$ & $\mathrm{U}$ & $\mathrm{U}$ & $\mathrm{U}$ & $\mathrm{T}^{4}$ & $\mathrm{U}^{4}+\mathrm{T}^{4}$ \\
\hline
\end{tabular}

${ }^{4}$ The sample represents a blend of water from more than one well. 


\section{Groundwater Quality in Geauga County, Ohio-Status, 2009, and Changes During 1978-2009}

Cover Database (Homer and others, 2007). The number of acres permitted for biosolids application (Ohio Environmental Protection Agency, 2010a) within each quarter circle also was documented, along with the number of producing oil and gas wells (Ohio Department of Natural Resources, 2008a).

To characterize the number of people within the upgradient quarter circle, a map of population distribution (fig. 5) was created as described below by using the 2001 National Land Cover Database and population from the 2000 census blocks (U.S. Census Bureau, 2009; Tele Atlas North America, Inc., 2008). A weighting scheme was applied with the areas that corresponded to some land-cover classes, such as developed, being assigned a higher relative density than other areas, such as those characterized as water. The total count of people within a census block remained the same as the census-published data, but the estimated distribution of people within the census block was no longer arbitrary. This dasymetric mapping technique more accurately portrays the actual distribution of population within a census block than a mapping method that uses one population value for the entire area of the census block.

The strength of the association between land use (2001) or population (2000) upgradient of a well and a constituent concentration in water from the well (in 2009 for domestic wells or 2000-2010 for public-supply wells) was measured by the nonparametric Spearman's rho correlation coefficient. Correlation analysis of activities at land surface to quality of water from wells sampled for this study has some limitations:

1. Not all sampled wells are likely to be affected by recent activities at land surface, because constituents applied at land surface will take longer to reach wells with open intervals at greater depths than those with shallower open intervals. Although tritium analyses from a previous study indicate that water from most wells tapping glacial deposits, the Pottsville Formation, and the Cuyahoga Group entered the groundwater system after 1953 (Jagucki and Darner, 2001) — and thus may be affected by land use after this time - tritium analyses of a limited number of samples from the Berea Sandstone indicate that water in this aquifer recharged prior to 1953 (when population and percent developed land were much less than they were in the years 2000 and 2001). Furthermore, simulations of groundwater flow by Eberts and others (1990) estimated that water in the Berea Sandstone recharged the water table hundreds of years ago (fig. 2); thus, land-surface activities in 2001 will be unlikely to have influenced current (2009) water quality in wells tapping the Berea Sandstone.

2. A large component of water reaching the deeper wells likely originated from farther away than $500 \mathrm{~m}$ and may be influenced by land use characteristics outside of the 500-m quarter circle.

3. Groundwater withdrawn from a well likely is a mixture of water that recharged during a range of years rather than during a single year. For an ideal comparison of land cover to water quality, computer simulations of groundwater flow would be used to track groundwater movement in reverse and estimate when and where water that is currently in the open interval of a well recharged the groundwater system. Next, land cover in the recharge area during the applicable year(s) would be compared to current water quality. However, such detailed tracking of groundwater flow and land cover were beyond the scope of this project. Because a comparison of landcover changes from 1992 to 2001 (fig. 6, this report) and from 1975 to 1996 (table 2, Jagucki and Darner, 2001) indicates that percentages of major land-cover categories have not changed dramatically since 1975 , a simplified comparison of land cover during a single year to recent water quality is useful for this study area.
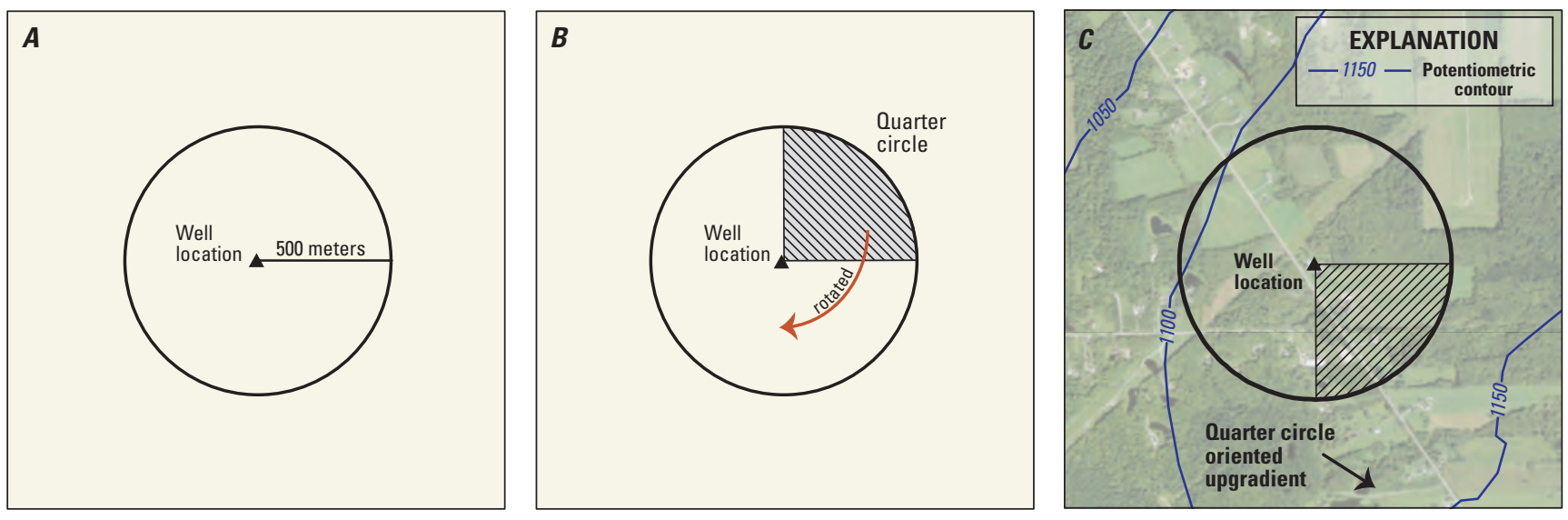

Figure 13. Method used to determine area for categorizing upgradient land use and population. A 500-meter radius was generated around each well (A), converted into a quarter circle, and rotated (B) to orient it to an upgradient groundwater-flow as determined by Jagucki and Lesney (1995). Land use and population density data within the quarter circle were then extracted (C). Figure modified from Button (2003). 
Thus, analyses of correlation of land cover and population to groundwater quality must be interpreted with caution. Although a lack of a correlation between 2001 land cover and 2009 constituent concentrations does not mean that such activities will never affect the quality of water in downgradient wells in the future, a positive correlation can provide useful insights.

\section{Statistical Analysis to Evaluate Changes Over Time}

Changes in water quality since 1978 were evaluated by using data collected by the USGS for 16 wells sampled across the county in 2009 (table 3) and using another 100 samples collected during previous studies from these 16 wells plus 49 additional wells (appendix table 4-1). Only data collected by the USGS were considered in this analysis to so that sources of variability introduced by sample collection, handling, and laboratory analysis would be minimized. USGS personnel used similar sample collection methods during each year, and all samples were analyzed at one lab - the USGS National Water Quality Laboratory - with the exception of nutrients, which were analyzed by Heidelberg University (Tiffin, Ohio) in 1999. Even so, analytical procedures, instruments, and laboratory reporting levels within the USGS National Water Quality Laboratory sometimes changed between 1978 and 2009.

All groundwater-quality data were retrieved from the USGS National Water Information System (NWIS) database. Data were available on a countywide basis for the years 1978, 1980, 1986, 1999, and 2009 (appendix table 4-1). Rarely, the same well had been sampled twice in one year; in these cases, a single sample for each year (one collected in spring or summer) was used in the statistical analysis. All samples represent water from the aquifer prior to any type of treatment.

For all statistical analyses of changes over time, concentrations of a given constituent were censored to a common reporting level equal to the highest laboratory reporting level used for that constituent during 1978-2009. (The laboratory reporting level for a given analyte and laboratory can change as often as annually.) All values reported as less than the common reporting level were assigned the same value that was less than all reported concentrations, so that ranks of values below the highest reporting level would be tied, yet lower than the rank for the lowest detected measurement (Helsel, 2005). For all statistical tests, a p-value of less than 0.05 was deemed to be statistically significant.

Changes over time were evaluated one of three ways, depending on whether or not the data were from a variable set of wells or a single well network that was able to be resampled in subsequent years, and on the number of nondetections ("nondetects") for a given constituent:
1. For constituents that were analyzed for in samples collected from the same well during successive years (1986 and 1999, and [or] 1999 and 2009), pairs of data from repeated analyses in a given well were compared by using a Wilcoxon signed-rank test. These "paired" data provide snapshots of water quality at the same well several years apart. The well-selection process in 1999 and 2009 focused on maximizing the number of wells that were resampled so that this statistical test could be used. The Wilcoxon signed-rank test looks at the magnitude of differences between the pair of concentration measurements at each resampled well and determines whether the median difference of all paired measurements is significantly different from zero (Helsel, 2005). The advantage of considering only resampled wells is that the variation or "background noise" in the dataset is minimized. (For example, when a different set of wells is sampled each year, variation caused by sampling wells of different depths in different years can obfuscate the effect being studied (changes with time) (Helsel, 2005; Helsel and Hirsch, 2002). A disadvantage of this test method is that data from all aquifers were grouped together for the statistical test; because of the small sample size (a total of 16 paired samples for 1999 and 2009), data could not be separated out by aquifer. Grouping data from multiple aquifers can hinder detection of differences in concentration between years if such differences occur only in a single aquifer. The Wilcoxon signed-rank test was used for constituents for which at least 50 percent of the samples had detectable concentrations. A two-sided test was done to test for either an increase or decrease in concentration between years.

2. For constituents that were analyzed for during three or more years between 1978 and 2009, changes over time were evaluated by using a nonparametric Spearman's rho correlation test. In general, a variable set of wells was sampled each year (because resampling of the same wells often was not possible). Spearman's rho measures the strength of the association between sampling year and constituent concentration (or how likely it is that concentration consistently increases or decreases as time increases). This method was used for constituents that had detectable concentrations in at least 50 percent of the samples (and thus are considered to be frequently detected constituents). The advantages of this test are that temporal trends in each individual aquifer can be evaluated and that data from the entire period of record can be utilized. The disadvantage is that variation or "background noise " can be introduced by sampling a different set of wells each year that may obfuscate the effect being studied (changes with time) (Helsel, 2005). 


\section{Groundwater Quality in Geauga County, Ohio-Status, 2009, and Changes During 1978-2009}

3. For constituents that were analyzed during two or more years but had a fewer than 50 percent detections (total coliform bacteria, nitrate, orthophosphate, and sulfide), graphical rather than statistical methods of evaluating temporal changes in water quality were used because of confounding factors that could interfere with an accurate calculation of statistical significance for these constituents. Confounding factors include median concentrations that are below the reporting limit in most years; constituents that are present only in certain aquifers, geochemical environments, elevations, and (or) depths so that well selection can greatly affect results; or the chlorination of wells between sampling rounds, which may affect bacteria concentrations. For the four constituents, detection frequency was graphically compared during successive years. (Detection frequency is the percentage of data above the common censored level for a constituent during a given year; that is, the number of detections divided by the total number of samples for a year.) In addition, concentrations of these four constituents were compared by use of bar charts for samples collected in successive years from the same well.

The use of quality-assurance/quality-control data to assess the effect of sample reproducibility and temporal laboratory variability on the statistical evaluation of changes in constituent concentrations over time is described in appendix 2 .

\section{Evaluation of Oxidation-Reduction Conditions in the Subsurface}

Microbial-induced chemical reactions in the subsurface can control the concentration of several naturally occurring constituents in groundwater as well as how persistent some manmade contaminants will be in the subsurface. Based on the measured concentration of dissolved oxygen, nitrate, manganese, iron, and sulfate in 116 samples collected by the USGS during 1978-2009, the oxidation-reduction-or redox-condition of each sample was categorized according to criteria defined by Jurgens and others (2009). Redox categories used in this report are oxic, suboxic, and the following types of reducing conditions: manganese reducing, iron and (or) sulfate reducing (also referred to as "strongly reducing"), or methanogenic.

\section{Groundwater Quality}

Groundwater-quality data were evaluated to answer the following questions: (1) Are there any constituents in Geauga County groundwater in 2009 that may adversely affect human health or aesthetics of drinking water? (2) How do constituent concentrations compare to those found elsewhere in Ohio and in the Nation, as reported in recent studies (DeSimone and others, 2009; Francy and others, 2004; Gilliom and others, 2006; Ohio Environmental Protection Agency, 2012b; Zogorski and others, 2006)? (3) How frequently is methane detected in water wells? (4) Have concentrations of water-quality constituents changed over time, since samples were first collected by the USGS in 1978? (5) What factors affect constituent concentrations and occurrence, including human activities at land surface, aquifer tapped by a well, and well construction?

\section{Status in $\mathbf{2 0 0 9}$}

The status of groundwater in the county, and its potential effect on human health as a source water for drinking, was assessed on the basis of analyses of water from 16 domestic wells and wells serving very small public-supplies (table 3 ) sampled by USGS personnel in 2009 (hereafter collectively referred to as "domestic wells"), as well as Ohio EPA water quality-data for 7 public-supply well fields (table 4), compiled for the period 2000-2010 unless otherwise noted. Publicsupply-well data were included to provide additional information about groundwater quality in the more populated areas of the county, particularly regarding concentrations of manmade contaminants such as pesticides and VOCs. By focusing as much as possible on untreated groundwater (samples of "source water"), the assessment of groundwater described below complements monitoring done by water utilities that typically focus on the chemistry of drinking water delivered to the public. Safety of drinking water at the tap is reported by water utilities annually in consumer confidence reports that are issued to customers.

\section{Comparison to Health-Based Benchmarks}

Concentrations of water-quality constituents measured in 2009 were compared to benchmarks for human health, if established (appendix tables 4-1and 4-2), and to aesthetic standards to determine the suitability of groundwater for drinking. Most health-based benchmarks were derived from drinking-water standards and guidelines established by the USEPA (2006 and 2009) (see sidebar). For public-supply wells or well fields serving 25 or more people, benchmarks based on MCLs are legally enforceable by the USEPA. However, domestic wells in Geauga County are only required to meet the health-based benchmarks for total coliform, Escherichia coli (E. coli) bacteria, and other fecal indicator microorganisms (Ohio Department of Health, 2011a). The total coliform benchmark is established by the Ohio Administrative Code and enforced by the Geauga County Health District (2010a). Testing for nitrate, total coliform, and E. coli bacteria is required on untreated water from a newly drilled or altered domestic well, or for a well located on a property that is being sold or refinanced (Ohio Department of Health, 2011a; Geauga County Health District, 2010a). 


\section{Human-Health Benchmarks for Contaminants in Groundwater}

Most of the benchmarks for assessing the potential for chemical constituents in water to affect human health were derived from five types of drinking-water standards and guidelines developed by USEPA's Office of Water (U.S. Environmental Protection Agency, 2006, 2009):

Maximum Contaminant Level (MCL) - The maximum permissible concentration of a contaminant in water that is delivered to any user of a public water system. This is a legally enforceable standard issued by USEPA under the Safe Drinking Water Act and established on the basis of health effects and factors such as the availability of affordable analytical and treatment technologies.

Lifetime Health Advisory (HA-L) - The concentration of a chemical in drinking water at or below which there is not expected to be any adverse, noncarcinogenic effects over a lifetime of exposure. A health advisory is not a legally enforceable Federal standard but serves as technical guidance to assist Federal, State, Tribal, and local officials. The HA-L is based on toxicity (dose-response) information for the chemical. It assumes lifetime consumption of 2 liters (L) of water per day by a 70-kilogram (154-pound) adult and that 20 percent of total exposure to the contaminant comes from drinking water whereas 80 percent comes from other sources.

$10^{-6}$ Cancer Risk Concentration (HA-C) - The concentration of a chemical in drinking water corresponding to an excess estimated lifetime cancer risk of 1 in 1 million $\left(10^{-6}\right)$. (The excess cancer risk means that it is in addition to any cancer risk borne by a person not exposed to the chemical of interest.) HA-C values are calculated from the estimated cancer potency, which is derived using a conservative (protective) model of carcinogenesis, so that the cancer risk is an upper-limit estimate. USEPA's policy is to accept measures adopted by States to limit cancer risk to the range of $10^{-6}$ to $10^{-4}$, meaning that 1 in 1 million to 1 in 10,000 people will get cancer by consuming a chemical in drinking water at the specified level (U.S. Environmental Protection Agency, 1992). The concentration corresponding to a cancer risk of $10^{-6}$ was used as the benchmark for the purposes of this report.

Action Level-The level of copper or lead in water at or above which additional steps are required to reduce the contaminant concentration (such as reducing the corrosiveness of the water). For regulatory purposes, the action level is applied only to tapwater samples of public-supply wells and only if more than 10 percent of the samples exceed the action level.

Drinking Water Advisory (DWA) - The concentration of a contaminant in water at or below which there are likely to be no adverse effects on health and aesthetics. A greater concentration may have adverse effects, with the likelihood increasing as the concentration increases. DWAs are not legally enforceable. The DWA for sodium applies only to people on a 500 milligram per day restricted sodium diet.

If available, the MCL was used as the human-health benchmark for a given water-quality constituent. For constituents with no MCL, the lower of the HA-L and the HA-C was used. The Action Level was used for the constituents lead and copper. The DWA was used if no MCL, HA-L, or HA-C exists and is of lesser concern.

(Sidebar modified from Gilliom and others, 2006, p. 91.)

Forty-one of the 92 properties and constituents analyzed for in water samples from domestic wells in 2009 had human-health benchmarks to which analytical results could be compared, as listed in appendix tables 4-1 and 4-2. Four of these benchmarks - for arsenic, total coliform bacteria, fecal coliform bacteria, and sodium—were exceeded in some domestic well samples (table 5). Some samples from publicsupply wells exceeded human-health benchmarks for arsenic, cadmium, lead, and sodium. Notable results are described below. Factors that affect where these constituents of concern are likely to occur are discussed in a subsequent section of the report. 


\section{Groundwater Quality in Geauga County, Ohio-Status, 2009, and Changes During 1978-2009}

Table 5. Exceedances of health-based benchmarks and aesthetically based standards in water quality of 16 domestic wells (2009) and 7 public-supply well fields (2000-2010) in Geauga County, Ohio.

$[\mu \mathrm{g} / \mathrm{L}$, micrograms per liter; mg/L, milligrams per liter; mL, milliliter; MCL, Maximum Contaminant Level; OAC, Ohio Administrative Code; DWA, Drinking Water Advisory; SMCL, Secondary Maximum Contaminant Level; NA, not available; >, greater than. Red text denotes samples that exceeded the water-quality benchmark. Human-health benchmarks and health effects are derived from standards and guidelines established by the U.S. Environmental Protection Agency (2003, 2006, and 2009) for concentrations of contaminants in drinking water, unless otherwise noted. Common sources of constituents are from Hem (1989) and the U.S. Environmental Protection Agency (2009)]

\begin{tabular}{|c|c|c|c|c|c|c|}
\hline \multirow[t]{2}{*}{$\begin{array}{l}\text { Bench- } \\
\text { mark } \\
\text { type }\end{array}$} & \multirow[t]{2}{*}{ Constituent } & \multirow[t]{2}{*}{$\begin{array}{l}\text { Water quality } \\
\text { benchmark }^{1}\end{array}$} & \multicolumn{2}{|c|}{$\begin{array}{l}\text { Number of wells } \\
\text { exceeding drinking } \\
\text { water benchmark } \\
\text { out of total number } \\
\text { of wells or well } \\
\text { fields sampled }\end{array}$} & \multirow[t]{2}{*}{$\begin{array}{l}\text { Common sources } \\
\text { of constituent }\end{array}$} & \multirow[t]{2}{*}{$\begin{array}{l}\text { Potential effect of exceedance } \\
\text { on water use or health } \\
\text { (with long-term exposure) }\end{array}$} \\
\hline & & & Domestic & $\begin{array}{l}\text { Public- } \\
\text { Supply }\end{array}$ & & \\
\hline \multirow{3}{*}{ 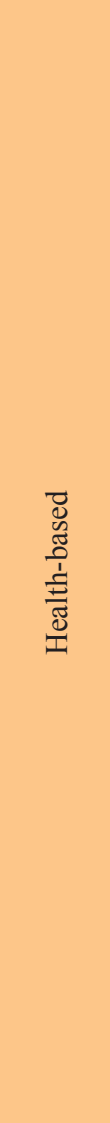 } & $\begin{array}{l}\text { Total } \\
\text { coliform } \\
\text { bacteria }\end{array}$ & $\begin{array}{l}\text { OAC }= \\
4 \text { total } \\
\text { coliform } \\
\text { colonies/ } \\
100 \mathrm{~mL}^{2}\end{array}$ & 2 of 16 & NA & $\begin{array}{l}\text { Soil or intestines of } \\
\text { warmblooded animals }\end{array}$ & $\begin{array}{l}\text { Indicates the possibility, but not the } \\
\text { certainty, that the water is contami- } \\
\text { nated with human or animal fecal } \\
\text { wastes. Pathogens in wastes may } \\
\text { cause diarrhea, cramps, nausea, head- } \\
\text { aches, or other symptoms. }\end{array}$ \\
\hline & $\begin{array}{l}\text { Fecal } \\
\text { coliform } \\
\text { bacteria }\end{array}$ & $\begin{array}{l}\mathrm{MCL}= \\
\text { no fecal } \\
\text { coliforms }\end{array}$ & 1 of 14 & NA & $\begin{array}{l}\text { Soil or intestines of } \\
\text { warmblooded animals }\end{array}$ & $\begin{array}{l}\text { Indicates the possibility, but not the cer- } \\
\text { tainty, that the water is contaminated } \\
\text { with human or animal fecal wastes. } \\
\text { Pathogens in wastes may cause diar- } \\
\text { rhea, cramps, nausea, headaches, or } \\
\text { other symptoms. }\end{array}$ \\
\hline & Cadmium & $\begin{array}{l}\mathrm{MCL}= \\
5 \mu \mathrm{g} / \mathrm{L}\end{array}$ & 0 of 4 & 1 of 4 & $\begin{array}{l}\text { Corrosion of galvanized } \\
\text { pipes; aquifer rocks and } \\
\text { sediments; industrial } \\
\text { sources }\end{array}$ & Kidney damage. \\
\hline \multicolumn{7}{|c|}{${ }^{1}$ For definitions of health-based water quality benchmarks, see sidebar, p. 27.} \\
\hline & $\begin{array}{l}{ }^{2} \text { OhioAdmir } \\
\text { ing (Ohio Depa } \\
\text { untreated wate } \\
\text { a property that }\end{array}$ & $\begin{array}{l}\text { rative Code }(\mathrm{O} \\
\text { nent of Health, } \\
\text { om a newly con } \\
\text { been sold or re }\end{array}$ & $\begin{array}{l}\text { C) standard f } \\
\text { 12). The Gec } \\
\text { ructed well, } \\
\text { inanced (Geat }\end{array}$ & $\begin{array}{l}\text { a } 100-\mathrm{mL} \\
\text { ga County } \\
\text { vell that has } \\
\text { a County } \mathrm{H}\end{array}$ & $\begin{array}{l}\text { lt sample from a private water } \\
\text { d District requires that this st } \\
\text { th District, 2010). }\end{array}$ & $\begin{array}{l}\text { tem in Ohio with } 25 \text { or more feet of cas- } \\
\text { lard be met during compulsory testing of } \\
\text { ion or water system configuration, or a well on }\end{array}$ \\
\hline
\end{tabular}


Table 5. Exceedances of health-based benchmarks and aesthetically based standards in water quality of 16 domestic wells (2009) and 7 public-supply well fields (2000-2010) in Geauga County, Ohio.-Continued

$[\mu \mathrm{g} / \mathrm{L}$, micrograms per liter; mg/L, milligrams per liter; mL, milliliter; MCL, Maximum Contaminant Level; OAC, Ohio Administrative Code; DWA, Drinking Water Advisory; SMCL, Secondary Maximum Contaminant Level; NA, not available; >, greater than. Red text denotes samples that exceeded the water-quality benchmark. Human-health benchmarks and health effects are derived from standards and guidelines established by the U.S. Environmental Protection Agency $(2003,2006$, and 2009) for concentrations of contaminants in drinking water, unless otherwise noted. Common sources of constituents are from Hem (1989) and the U.S. Environmental Protection Agency (2009)]

\begin{tabular}{|c|c|c|c|c|c|c|}
\hline \multirow[t]{2}{*}{$\begin{array}{l}\text { Bench- } \\
\text { mark } \\
\text { type }\end{array}$} & \multirow[t]{2}{*}{ Constituent } & \multirow[t]{2}{*}{$\begin{array}{l}\text { Water quality } \\
\text { benchmark }^{1}\end{array}$} & \multicolumn{2}{|c|}{$\begin{array}{l}\text { Number of wells } \\
\text { exceeding drinking } \\
\text { water benchmark } \\
\text { out of total number } \\
\text { of wells or well } \\
\text { fields sampled }\end{array}$} & \multirow[t]{2}{*}{$\begin{array}{l}\text { Common sources } \\
\text { of constituent }\end{array}$} & \multirow[t]{2}{*}{$\begin{array}{l}\text { Potential effect of exceedance } \\
\text { on water use or health } \\
\text { (with long-term exposure) }\end{array}$} \\
\hline & & & Domestic & $\begin{array}{l}\text { Public- } \\
\text { Supply }\end{array}$ & & \\
\hline \multirow{5}{*}{ 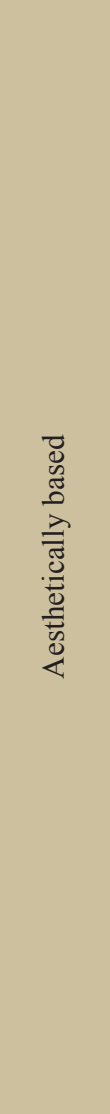 } & Iron & $\begin{array}{l}\mathrm{SMCL}^{3}= \\
\quad 300 \mu \mathrm{g} / \mathrm{L}\end{array}$ & 10 of 16 & 3 of 4 & $\begin{array}{l}\text { Aquifer sediments and } \\
\text { rocks }\end{array}$ & $\begin{array}{l}\text { Staining of fixtures, utensils, and } \\
\text { laundry. Higher concentrations form } \\
\text { reddish-brown sediment and water- } \\
\text { line deposits and may give the water } \\
\text { a metallic taste. }\end{array}$ \\
\hline & Manganese & $\begin{array}{l}\mathrm{SMCL}= \\
\quad 50 \mu \mathrm{g} / \mathrm{L}\end{array}$ & 10 of 16 & 3 of 4 & $\begin{array}{l}\text { Aquifer sediments and } \\
\text { rocks }\end{array}$ & $\begin{array}{l}\text { Dark-brown or black staining of } \\
\text { fixtures, utensils, and laundry. }\end{array}$ \\
\hline & $\begin{array}{l}\text { Total } \\
\text { dissolved } \\
\text { solids }\end{array}$ & $\begin{array}{l}\mathrm{SMCL}= \\
\quad 500 \mathrm{mg} / \mathrm{L}\end{array}$ & 2 of 16 & 2 of 3 & $\begin{array}{l}\text { Dissolution of aquifer } \\
\text { minerals; road salt; } \\
\text { brines; septic leachate }\end{array}$ & $\begin{array}{l}\text { Concentrations }>1,000 \mathrm{mg} / \mathrm{L} \text { may cause } \\
\text { objectionable tastes and laxative } \\
\text { effects. Also my cause foaming or } \\
\text { may corrode some metals. }\end{array}$ \\
\hline & Chloride & $\begin{array}{l}\mathrm{SMCL}= \\
250 \mathrm{mg} / \mathrm{L}\end{array}$ & 0 of 16 & 1 of 3 & $\begin{array}{l}\text { Dissolution of aquifer } \\
\text { minerals; road salt; } \\
\text { brines; septic leachate }\end{array}$ & $\begin{array}{l}\text { At concentrations }>250 \text { to } 400 \mathrm{mg} / \mathrm{L} \text {, } \\
\text { imparts a salty taste to water depend- } \\
\text { ing on individual tolerance. High } \\
\text { concentrations are corrosive to most } \\
\text { metals. }\end{array}$ \\
\hline & $\mathrm{pH}$ & $\begin{array}{l}\mathrm{SMCL}= \\
6.5-8.5\end{array}$ & 1 of 16 & 1 of 3 & $\begin{array}{l}\text { Controlled by chemical } \\
\text { reactions that produce } \\
\text { or consume hydrogen } \\
\text { ions in water, such as } \\
\text { the reaction of dis- } \\
\text { solved carbon dioxide } \\
\text { gas with water, mineral } \\
\text { dissolution reactions, } \\
\text { and oxidation reactions }\end{array}$ & $\begin{array}{l}\text { Values outside the recommended range } \\
\text { of } 6.5 \text { to } 8.5 \text { may be corrosive to } \\
\text { metal well casings and pipes. A pH } \\
\text { below } 6.5 \text { can generate health-related } \\
\text { problems by dissolving small quanti- } \\
\text { ties of trace metals such as lead, } \\
\text { especially in a house built before lead } \\
\text { solder was banned in } 1987 \text {. }\end{array}$ \\
\hline
\end{tabular}

${ }^{3}$ Secondary Maximum Contaminant Limit (SMCL) is the concentration of a contaminant in drinking water above which cosmetic effects (such as skin or tooth discoloration) or aesthetic effects (such as taste, odor, or color) may occur. The Environmental Protection Agency recommends SMCLs to water systems but does not require them to comply. 


\section{Groundwater Quality in Geauga County, Ohio-Status, 2009, and Changes During 1978-2009}

\section{Arsenic}

Prior to 2009, arsenic concentrations in groundwater samples from domestic wells had not been widely measured in Geauga County. (Seven domestic and three public-supply wells had been analyzed for arsenic by the USGS in 1978 and 1980.) The impetus to include arsenic in the most recent USGS sampling round was the lowering of the MCL from 50 $\mu \mathrm{g} / \mathrm{L}$ to $10 \mu \mathrm{g} / \mathrm{L}$ on January 1,2006 , for all community and non-transient water systems (Ohio Environmental Protection Agency, 2006b). The MCL was lowered because a review by the National Academy of Sciences of worldwide studies of arsenic health effects concluded that the risk level at $50 \mu \mathrm{g} / \mathrm{L}$ was higher than previously thought (Ohio Environmental Protection Agency, 2006b).

Arsenic occurs naturally (but is distributed unevenly) in some sediments and rocks, and it can dissolve into groundwater under certain geochemical conditions. Regular ingestion of arsenic in water at concentrations exceeding the MCL of $10 \mu \mathrm{g} / \mathrm{L}$ can increase the risk of long-term or chronic health problems such as lung, bladder, skin, kidney, nasal, liver, and prostate cancer. Low levels of arsenic can also cause skin damage or problems with circulatory, pulmonary, immune, nervous, and endocrine systems (Ohio Environmental Protection Agency, 2006b; http://arsenicinohiogroundwater.info/). Arsenic in water has no smell or taste, so water must be tested to determine whether the arsenic concentration exceeds the MCL.

Domestic wells. - Concentrations of arsenic in the two wells exceeding the MCL (table 5) were $12.9 \mu \mathrm{g} / \mathrm{L}$ (GE-202) and $13.2 \mu \mathrm{g} / \mathrm{L}$ (GE-108) (locations shown in fig. 12). Wells GE-202 and GE-108 draw water from the Pottsville Formation and the glacial deposits, respectively. The median concentration of arsenic in all sampled domestic wells was $1.1 \mu \mathrm{g} / \mathrm{L}$. Descriptions and comparisons of household water treatment options to remove arsenic are available at $\mathrm{http}: / /$ arsenicinohiogroundwater.info/. Arsenic-specific treatment is needed because boiling water will not remove arsenic; neither will chlorine (bleach) disinfection (New Hampshire Department of Environmental Services, 2006), common household water softeners, sediment filters, or activated carbon filters (http:// arsenicinohiogroundwater.info/).

Public-supply well fields.-Arsenic data were available for six of the seven public-supply well fields examined for this study. Both untreated and treated water concentrations were considered. Arsenic concentrations exceeding the MCL were recorded in two of these well fields (table 5) over the last decade, with maximum concentrations of $17 \mu \mathrm{g} / \mathrm{L}$ in Chardon City (well 3, fig. 12) and $20 \mu \mathrm{g} / \mathrm{L}$ in Middlefield Village (well 6 , fig. 12). However, arsenic concentrations were reduced to levels below the MCL when these two community water systems began using macrolite filtration to treat their water for arsenic in mid-2008 (Dan Sellito, 2011, City of Chardon Water and Wastewater, written commun., 2011; Michael Cipolla, Village of Middlefield Water Treatment Department, oral commun., 2011).

\section{Total and Fecal Coliform Bacteria}

Total coliform bacteria, fecal coliform bacteria, and a species of fecal coliform bacteria called $E$. coli are considered to be indicator organisms; their presence does not constitute a health hazard in itself but indicates a possibility (but not a certainty) that disease-causing organisms also may be present in the water because of contamination from human or other animal waste. The human-health benchmark for total coliform (table 5, 4 colonies per 100 milliliters [mL] of water) applies to domestic wells with $25 \mathrm{ft}$ or more of casing. Wells with less than $25 \mathrm{ft}$ of casing that use continuous disinfection should contain no total coliforms (Ohio Department of Health, 2012).

Domestic wells.-Total coliform bacteria were detected in 5 of 16 domestic wells sampled in 2009 (over 31 percent) but were present at concentrations exceeding the health benchmark of 4 colonies per $100 \mathrm{~mL}$ of water in only 2 of these wells (12.5 percent) (table 5 and appendix table 4-1). Because total coliform bacteria can also occur naturally in the soil and in plants, their presence does not necessarily indicate a sewage-contamination problem or imminent health risk. However, the Ohio Department of Health suggests that wells containing more than 4 total coliform bacteria per $100 \mathrm{~mL}$ be professionally cleaned, chlorinated, and retested, because this can indicate poor well construction, a buildup of bacterial and mineral slimes in the well, or the presence of holes in the well casing due to aging of the well (Ohio Department of Health, 2011b, 2012). Water from well GE-141, in which the highest total coliform concentration was detected (49 colonies per $100 \mathrm{~mL}$ of water), also contained detectable fecal coliform (estimated at 1 colony per $100 \mathrm{~mL}$ of water), suggesting a possible health risk to people consuming this water. No E. coli bacteria, which originate only in the intestines of humans or other warmblooded animals, were found in any of the 16 wells tested in the county.

Public-supply well fields. - The only available bacteria samples from public-supply well fields were collected after treatment (and treatment includes chlorination in six of the seven well fields). Thus, bacteria concentrations from publicsupply well fields were not evaluated because they would not be representative of water in the aquifer.

\section{Trace Metals}

Domestic wells. - Groundwater samples from four domestic wells (one in each aquifer) were analyzed for the trace metals cadmium, chromium, copper, lead, selenium, and zinc. Only lead and zinc were detected, but not at concentrations that exceeded health-based standards specified in appendix table 4-1.

Public-supply well fields.-Only untreated water from public-supply well fields was evaluated in comparison to health-based standards for the trace metals listed above. Untreated samples were available from four of the seven well fields (table 4). Cadmium exceeded the MCL $(5 \mu \mathrm{g} / \mathrm{L})$ in one of 13 samples from the Tanglewood Lake public-supply 
(well 7, fig. 12, maximum concentration of $18.8 \mu \mathrm{g} / \mathrm{L}$ ). The most likely cadmium source is corrosion of galvanized pipes. Two of 21 samples from ASM International public-supply (well 1, fig. 12) exceeded the lead action level of $15 \mu \mathrm{g} / \mathrm{L}$ (maximum concentration of $29.5 \mu \mathrm{g} / \mathrm{L}$ ), which represents an exceedance frequency of 9.5 percent for samples collected from a single well during 2000-2010. Although this comparison of untreated water to the lead action level provides some context for evaluating the healthfullness of aquifer water withdrawn by the public-supply wells, in reality the legal enforcement of the lead drinking-water standard evaluates treated water collected not from a single supply well but from customers' taps. Because most lead gets into drinking water after the water leaves the local well or treatment plant and comes into contact with plumbing materials containing lead (which were commonly used until 1986), water suppliers must employ a treatment technique to reduce the corrosiveness of their water if more than 10 percent of samples of treated water from customers' taps collected during a 6-month, annual, or triennial sampling exceed the lead action level (U.S. Code of Federal Regulations, 1987).

\section{Sodium}

Domestic wells. - Sodium concentrations exceeded the human-health benchmark of $20 \mathrm{mg} / \mathrm{L}$ (for persons with medical reasons for moderating dietary intakes of sodium) in 6 of 16 domestic wells sampled (38 percent). The maximum concentration measured was $86.9 \mathrm{mg} / \mathrm{L}$ at well GE-147 (appendix table 4-1). Note that all water samples were collected prior to passing through the home water treatment system. Homeowners who soften their water using ion exchange methods may be adding even more sodium content to their tapwater, because calcium, magnesium, iron, and manganese ions in groundwater replace sodium ions on the adsorption media, causing sodium to be released into the tapwater during the softening process (Driscoll, 1986).

Public-supply well fields.-Sodium concentrations exceeding, at least periodically, the human-health benchmark for people on a low-sodium diet $(20 \mathrm{mg} / \mathrm{L})$ were measured in untreated water from the four public-supply well fields for which untreated sodium data were available. The maximum measured concentration was $320 \mathrm{mg} / \mathrm{L}$ in a sample from Lake Lucerne public supply (well 5, fig. 12).

\section{Manganese}

Manganese occurs naturally in aquifer sediments and rocks and is dissolved into groundwater under certain geochemical conditions. Manganese at concentrations greater than $300 \mu \mathrm{g} / \mathrm{L}$ can cause undesirable neurological effects (Agency for Toxic Substances and Disease Registry, 2008).

Domestic wells.-No groundwater samples collected in 2009 exceeded the health-based benchmark (HA-L) of 300 $\mu \mathrm{g} / \mathrm{L}$ for manganese, so manganese is not listed as a constituent of concern in table 5. Historical data for 65 domestic wells sampled by the USGS since 1978, however, includes 5 wells (about 8 percent) that have exceeded $300 \mu \mathrm{g} / \mathrm{L}$ of manganese, with a maximum concentration of $1,200 \mu \mathrm{g} / \mathrm{L}$.

Public-supply well fields.-Manganese analyses of untreated water (2000-2010) were available for four of the seven public supply well fields. No samples exceeded the health-based benchmark for manganese.

\section{Pesticides}

Agricultural pesticides were a focus of this study because the nationwide use of pesticides on agricultural lands in 2001 was about three times that of nonagricultural use (Gilliom and others, 2006). The 52 pesticides $^{3}$ analyzed for in water from domestic wells (appendix table 4-2) include many of the herbicides (used to kill or control weeds) and insecticides (used to eradicate insects) that are most heavily used for agricultural applications in the Nation. Additionally, the pesticides analyzed for include four of the five pesticides (dieldrin, donoseb, atrazine, lindane, and diazinon) found to exceed human-health benchmarks in groundwater nationwide (Gilliom and others, 2006). Forty-six of the analyzed pesticides have a humanhealth benchmark (appendix table 4-2).

Domestic wells. - Of the 52 pesticides analyzed for, only the herbicide atrazine was detected at a concentration above the laboratory reporting level (appendix table 4-2), and it was found in only one well (GE-341, which taps the Cuyahoga Group aquifer, table 3). Atrazine was detected at a concentration of $0.0073 \mu \mathrm{g} / \mathrm{L}$, which is far below the MCL of $3 \mu \mathrm{g} / \mathrm{L}$. Water from GE-341 also contained a trace amount of the atrazine degradation product CIAT (2-chloro-4-isopropylamino-6-amino-s-triazine).

Public-supply well fields.-Very few analyses of pesticides in untreated water from the seven public-supply well fields were available for the period 2000-2010. However, the authors considered compliance analyses of pesticides in treated water from the supply wells during this period to be representative of water in the aquifers because conventional treatment methods (such as are used at these wells) do little to remove mobile pesticides (U.S. Environmental Protection Agency, 2001). Water samples from Lake Lucerne and Tanglewood Lake public-supply were analyzed for several pesticides for which health-based benchmarks are established: 2,4-D, alachlor, atrazine, carbofuran, diquat, endothall, glyphosate, metolachlor, metribuzin, oxamyl, picloram, and simazine. None of these pesticides were detected. Similarly, samples from the Burton Village, Middlefield Village, and City of Chardon public supply well fields were analyzed for the pesticides alachlor, atrazine, and simazine, which were not detected. Reporting levels for these analyses were at least an order of magnitude less than the health-based benchmark for each pesticide.

\footnotetext{
${ }^{3}$ The pesticide names used in this report refer to the active ingredient, rather than the product name, because multiple products can have the same active ingredient (Milne, 1995).
} 


\section{Groundwater Quality in Geauga County, Ohio-Status, 2009, and Changes During 1978-2009}

\section{Volatile Organic Compounds}

VOCs are manmade organic compounds used in products such as fuels, refrigerants, and industrial and dry-cleaning solvents. VOCs that were analyzed for in samples collected from domestic wells in 1999 (Jagucki and Darner, 2001) and in samples from the seven public-supply wells (1995-2009) are listed in appendix table 4-3. This list includes most of the VOCs that were detected during investigations of localized contamination of groundwater in Geauga County (fig. 11).

Domestic wells. - USGS personnel did not sample any domestic wells for VOCs in 2009. However, 31 groundwater samples collected in 1999 were analyzed for benzene, TCE, toluene, PCE, and xylene (Jagucki and Darner, 2001, p. 58), with no detections (appendix table 4-3).

Public-supply well fields. - VOCs were analyzed for in samples from the public-supply well fields on at least three separate dates from 1995 through 2009 (appendix table 4-3). Not all wells were analyzed at the same frequency. VOCs were analyzed for most often (9 times) at ASM International publicsupply (well 1, fig. 12). Analyses of both untreated and treated water are reported in table 4-3 and discussed below, because none of the seven public-supply wells examined for this study employ activated carbon, reverse osmosis, or air stripping treatment that would remove VOCs (New Jersey Department of Health and Senior Services, 1997; New Mexico Environment Department, 2008; Vermont Department of Health, 2011). The Burton Village public-supply well does, however, treat for iron by aeration, which could volatilize VOCs that are present in groundwater. VOCs may also be partially volatilized by high-capacity pumps used in public-supply wells; as a result, analyzed concentrations should be considered minimum values.

Of the almost 100 VOCs analyzed for in samples from the 7 public-supply well fields (appendix table 4-3), only chlorination byproducts (denoted by orange-highlighted text) were detected, with a single exception. Chlorination byproducts - various trihalomethanes and haloacetic acids - are not naturally present in groundwater. These compounds form when chlorine added to disinfect water combines with organic matter naturally present in the groundwater. This is exemplified by the water from Middlefield Village public supplyuntreated water samples contained no chlorination byproducts, but treated water did. Although it is not surprising that chlorination byproducts were found in treated water produced by most public-supply well fields, the presence of chlorination byproducts in untreated water from the Lake Lucerne publicsupply (the only well field besides Middlefield for which both untreated and treated water analyses were available) suggests that these VOCs are present in the aquifer at this location. Likely sources include the infiltration of chlorinated water to the subsurface through leakage from distribution pipes or watering of lawns. Maximum concentrations of total haloacetic acids and total trihalomethanes in both untreated and treated water from the studied public-supply wells did not exceed the human-health benchmarks (MCLs) for these compounds $(60 \mu \mathrm{g} / \mathrm{L}$ and $80 \mu \mathrm{g} / \mathrm{L}$, respectively).

Total xylenes (a solvent that is a component of gasoline) was the only VOC detected in any of the studied publicsupply wells that was not a chlorination byproduct. Two of 34 samples of treated water from the Lake Lucerne well field contained total xylenes at a concentration of $1.5 \mu \mathrm{g} / \mathrm{L}$. This concentration is considerably less than the human-health benchmark of $10 \mathrm{mg} / \mathrm{L}$. Both samples with detections were collected on the same day in 2008 from different locations in the system. No further detections occurred at this well field through 2010.

\section{Comparison to Aesthetically Based Standards}

In addition to drinking-water standards based on humanhealth benchmarks, standards called Secondary Maximum Contaminant Levels (SMCLs) were developed on the basis of constituent concentrations that affect taste, odor, staining of fixtures and laundry and sometimes skin and tooth color (U.S. Environmental Protection Agency, 2009). USEPA recommends that public water systems meet SMCLs but does not legally enforce these guidelines. Analytical results from domestic wells sampled in 2009 and from the seven publicsupply wells (untreated water only, 2000-2010) were compared to SMCLs (table 5).

Iron and manganese were the constituents that most affected the aesthetics of groundwater used for drinking and household purposes in Geauga County. Among the wells with available data, 62 percent of the domestic well samples and 75 percent of the public-supply well samples exceeded the SMCL for both iron $(300 \mu \mathrm{g} / \mathrm{L})$ and manganese $(50 \mu \mathrm{g} / \mathrm{L})$ (table 5). SMCLs for fluoride, sulfate, copper, and zinc were not exceeded in water from any sampled domestic well or public-supply well field.

Although hydrogen sulfide has no established healthbased or aesthetically based standards for drinking water, elevated concentrations of this constituent can adversely affect the odor of groundwater. Additionally, hydrogen sulfide gas can cause corrosion to metals commonly used in well casing and pump components, and it can cause yellow or black stains on bathroom fixtures (National Ground Water Association, 2013). Water samples from 16 domestic wells were analyzed for total sulfide, which can be in the form of hydrogen sulfide gas or can precipitate out of groundwater as a finely disseminated, black iron sulfide mineral. Total sulfide was detected at concentrations greater than $0.005 \mathrm{mg} / \mathrm{L}$ in water from $8(50$ percent) of the domestic wells. The maximum concentration measured was $0.124 \mathrm{mg} / \mathrm{L}$. A hydrogen sulfide odor was noted by USGS personnel in seven of the eight samples containing total sulfide, indicating that some of the sulfide is in the form of hydrogen sulfide gas. Total sulfide data were not available for the public-supply well fields considered in this study. 


\section{Comparison of Findings to State and National Studies of Water Quality}

To determine how the quality of groundwater from 16 domestic wells in Geauga County in 2009 compares to groundwater quality elsewhere, exceedance frequencies of health-based benchmarks or detection frequencies of selected constituents in Geauga County were compared to those found statewide and nationally (fig. 14). Ideally, all datasets compared would consist of samples from domestic wells (because public-supply wells capture water originating over a larger area than domestic wells); however, domestic well data were not available on a statewide basis. Instead, statewide data consist of water-quality analyses from Ohio EPA's Ambient Groundwater Quality Monitoring Program (Ohio Environmental Protection Agency, 2012b). This State program monitors untreated water from public-supply wells tapping the major aquifer systems of Ohio, with the goal of measuring long-term changes in water quality. Unless otherwise noted, the State exceedance frequencies described below are the percentages of wells sampled for which the mean concentration of all samples analyzed during 2001-2010 exceeded the MCL. Nationwide data used in this study, with the exception of pesticide and VOC data, are from a USGS study of untreated water from domestic wells in 48 states from 1991 through 2004 (DeSimone and others, 2009).

Arsenic.-Arsenic occurred at concentrations exceeding the MCL at about the same frequency in Geauga County groundwater as it did elsewhere in Ohio but more frequently than across the Nation as a whole (fig. 14A). Over half of the arsenic exceedances in Ohio occurred in water from wells completed in sand and gravel aquifers (Ohio Environmental Protection Agency, 2012b, table M-4B). (The glacial deposits of Geauga County fall within this category.) Exceedances were associated with reducing geochemical conditions in the aquifers and local areas of naturally occurring arsenic (Ohio Environmental Protection Agency, 2012b, p. M-22).

Bacteria.-Bacteria data were not available for public-supply wells in Ohio's Ambient Groundwater Quality Monitoring Program, so detection frequencies for bacteria in Geauga County were compared to data for sand and gravel aquifers in the neighboring state of Michigan from a study of 38 small public-supply wells (serving less than 3,300 people) (Francy and others, 2004). The detection frequency ${ }^{4}$ of total coliform bacteria in Geauga County in 2009 was similar to the detection frequency found in Michigan and the United States as a whole (fig. 14B). In contrast, E. coli detections in Geauga County ( 0 percent) were fewer than found in Michigan and across the rest of the Nation (fig. 14C).

\footnotetext{
${ }^{4}$ Detection frequency is discussed here rather than the exceedance frequency of the Ohio Department of Health human-health benchmark, because detection frequency was what was discussed in the National study by DeSimone and others (2009).
}

Nitrate.-Nitrate concentrations did not exceed the MCL of $10 \mathrm{mg} / \mathrm{L}$ in any of the 16 domestic wells sampled in Geauga County in 2009 (fig 14D). (The maximum measured concentration was $1.73 \mathrm{mg} / \mathrm{L}$.) Other data corroborate that nitrate concentrations in county groundwater tend to be low: (1) historical data for Geauga County domestic wells (93 samples collected by the USGS during 1978-2009) indicate that no domestic well samples had exceeded the nitrate MCL and (2) the maximum nitrate concentration measured in the seven public-supply well fields considered for this report was 3.85 $\mathrm{mg} / \mathrm{L}$. Nationwide, the exceedance frequency of the nitrate MCL was much greater (fig. 14D) than that in Geauga County or the rest of Ohio. Nitrate concentrations were highest in agricultural areas of the Nation and in older wells (DeSimone and others, 2009).

Pesticides.-Pesticides were detected in only 1 of the 16 domestic wells sampled in Geauga County - a much lower detection frequency (6 percent) than was found nationwide (Gilliom and others, 2006) (fig. 14E). These data are not directly comparable, however, because the threshold concentration for pesticide detection in the current study was about twice that of the nationwide study, ${ }^{5}$ and fewer detections can be expected when a higher threshold concentration is used. It is also likely, however, that hydrogeology and agricultural management practices contribute to the relatively low detection frequency of pesticides in Geauga County. Gilliom and others (2006) found that, in parts of the Nation where atrazine is heavily used on corn crops, atrazine was detected less frequently in groundwater beneath areas covered by relatively impermeable soils and glacial till (such as occurs in much of Geauga County) than in areas with permeable soils and geologic formations (such as parts of Iowa, Minnesota, Pennsylvania, and Wisconsin). Gilliom and others also credited subsurface tile-drain systems (commonly used in Ohio to drain waterlogged soils) with reducing pesticide levels in groundwater by diverting shallow groundwater to streams.

VOCs. - The detection frequencies of VOCs in Geauga County were not compared to nationwide detection frequencies reported by Zogorski and others (2006) because reporting levels used in the different studies were too dissimilar. Nonetheless, a general comparison indicates that chloroform, a chlorination byproduct that was detected in untreated water from one of four public-supply wells in Geauga County, is the most commonly detected VOC in Ohio's ambient well network (Slattery and others, 2006) and in domestic and public-supply wells nationwide (Zogorski and others, 2006). The frequency of chloroform detection is attributed, in part, to the infiltration of chlorinated waters to aquifers (Zogorski and others, 2006). Both statewide and nationally, VOC detections in wells used to supply drinking water typically occurred at

\footnotetext{
${ }^{5}$ The current Geauga County study uses the laboratory reporting level as its threshold for pesticide detection. The nationwide study by Gilliom and others (2006) used the long-term method detection level as its threshold. Both types of thresholds are defined by Oblinger Childress and others (1999). The laboratory reporting level is equal to the long-term method detection level multiplied by 2 .
} 
34 Groundwater Quality in Geauga County, Ohio-Status, 2009, and Changes During 1978-2009

$\boldsymbol{A}$

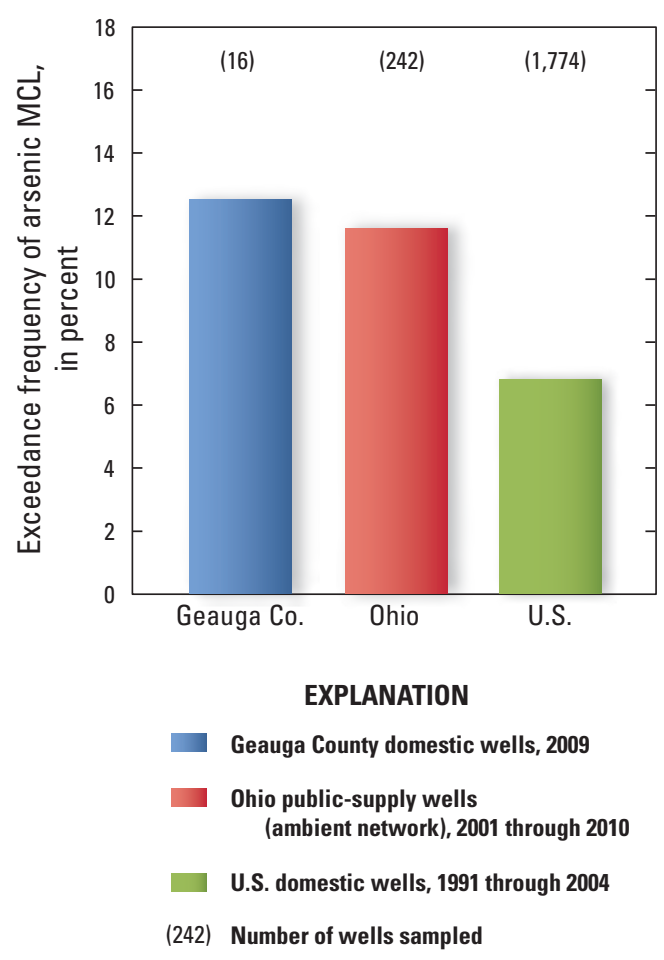

C

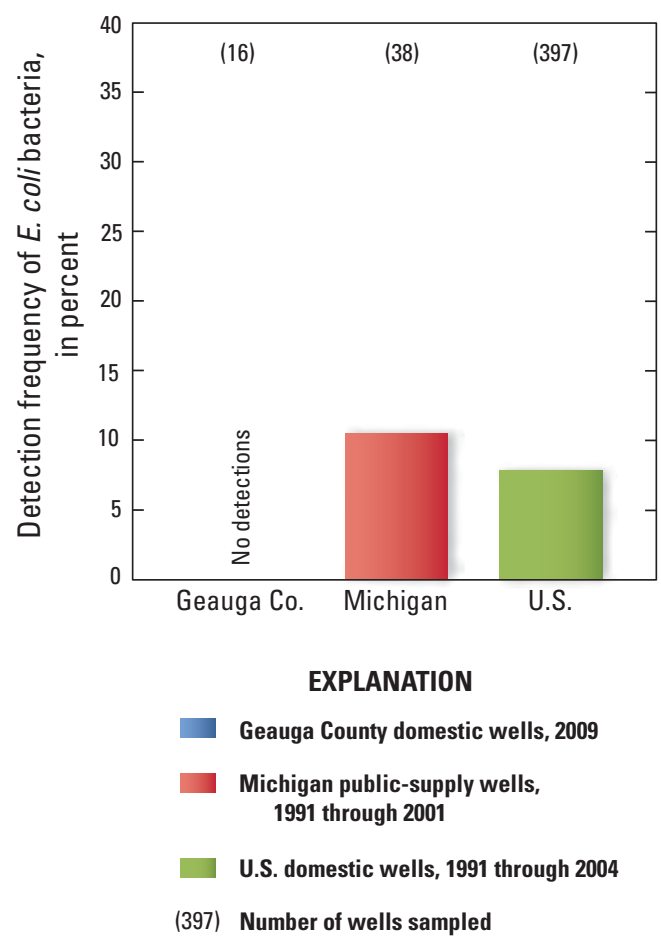

B

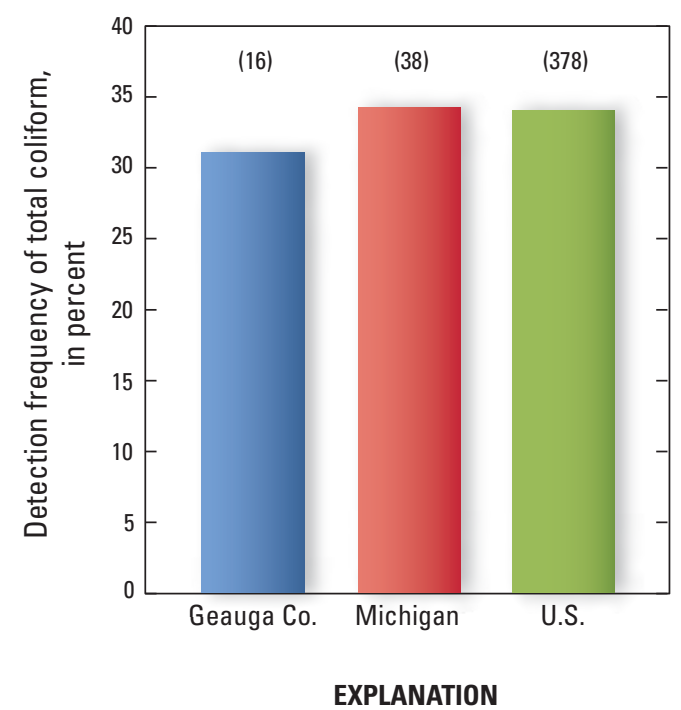

Geauga County domestic wells, 2009

Michigan public-supply wells, 1991 through 2001

U.S. domestic wells, 1991 through 2004

(378) Number of wells sampled

D

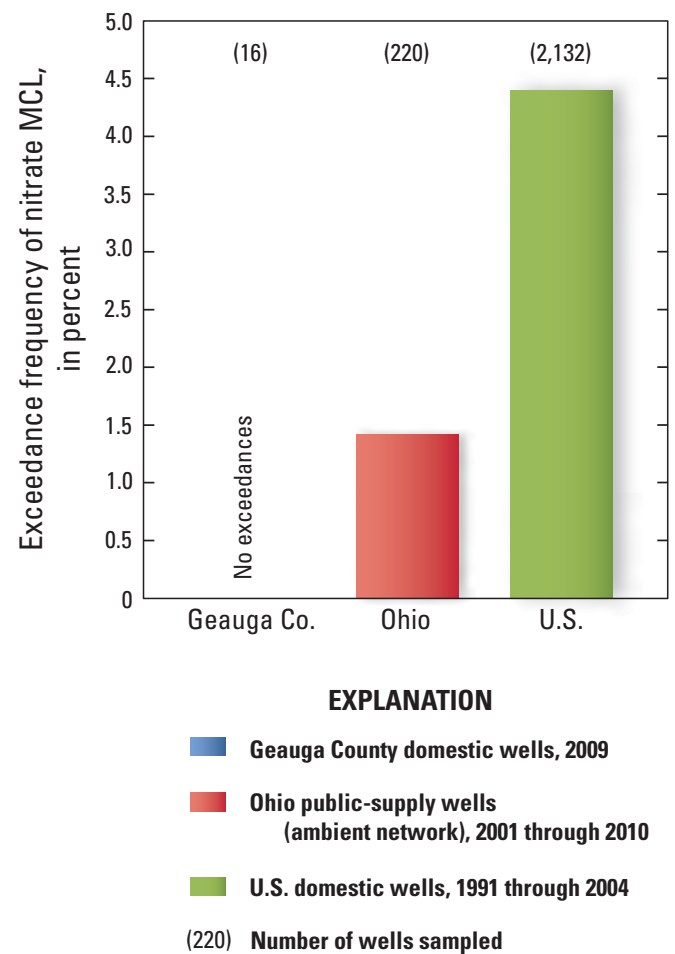

Figure 14. Comparison of detection frequencies or exceedance frequencies of health-based and aesthetically based benchmarks in groundwater at the county, state, and national level. (Data from Desimone and others [2009], Francy and others [2004], Gilliom and others [2006], and Ohio Environmental Protection Agency [2012b]; MCL, Maximum Contaminant Level; SMCL, Secondary Maximum Contaminant Level.) 
$\boldsymbol{E}$

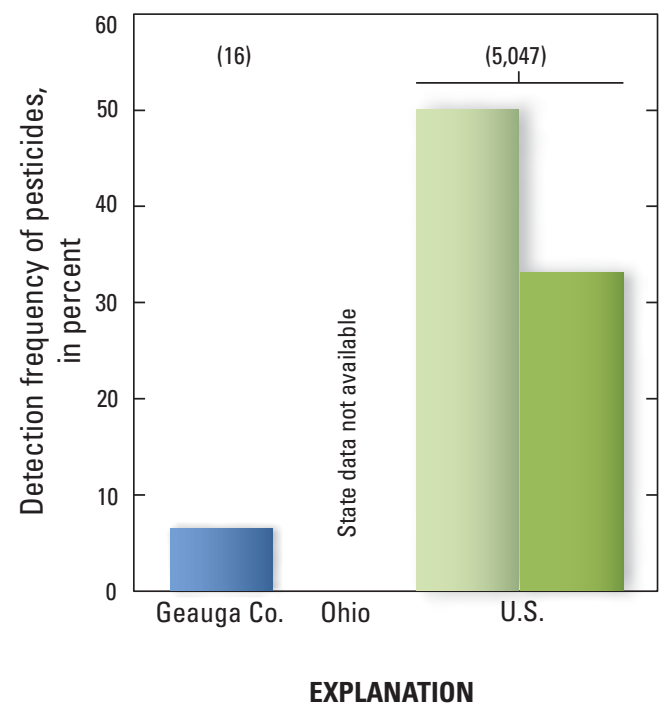

Geauga County domestic wells, 2009 U.S. Data, 1992 through 2001:

U.S. - shallow observation and domestic wells ( $<20 \mathrm{ft}$ below the water table)

U.S.- deeper domestic and public-

supply wells tapping major aquifers

(16) Number of wells sampled
$\boldsymbol{F}$

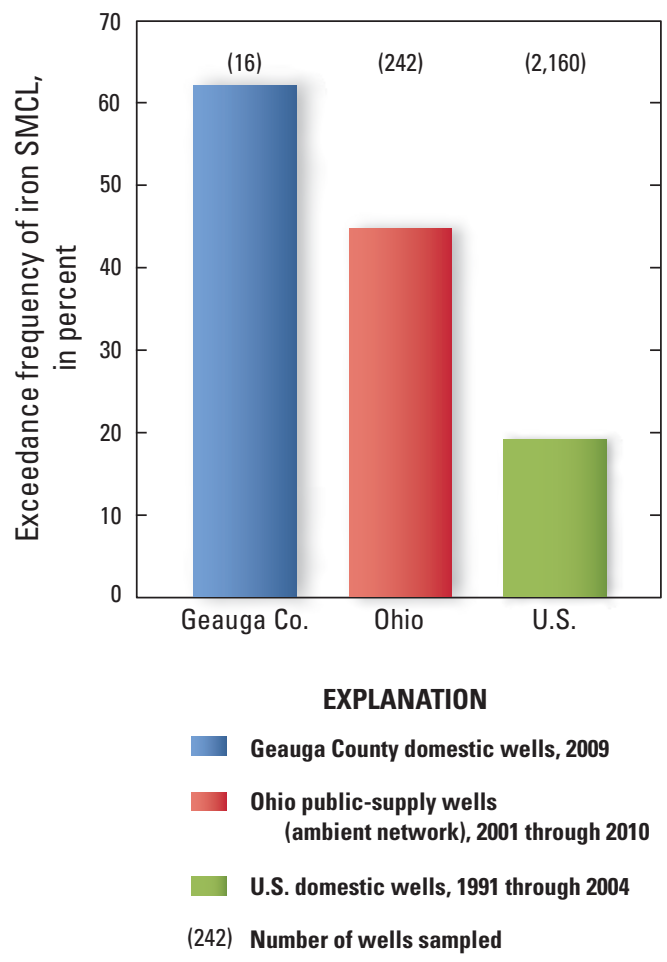

$\boldsymbol{G}$

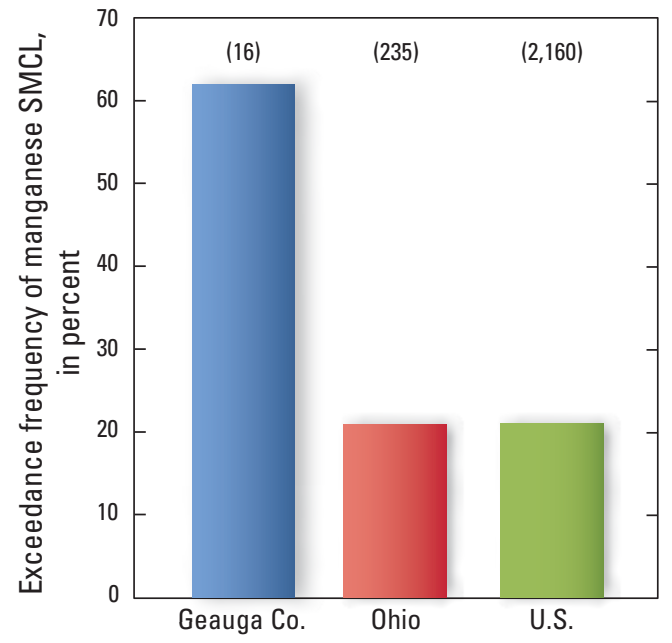

EXPLANATION

Geauga County domestic wells, 2009

Ohio public-supply wells

(ambient network), 2001 through 2010

U.S. domestic wells, 1991 through 2004

(235) Number of wells sampled

Figure 14. Comparison of detection frequencies or exceedance frequencies of health-based and aesthetically based benchmarks in groundwater at the county, state, and national level. (Data from Desimone and others [2009], Francy and others [2004], Gilliom and others [2006], and Ohio Environmental Protection Agency [2012b]; MCL, Maximum Contaminant Level; SMCL, Secondary Maximum Contaminant Level.)-Continued 


\section{Groundwater Quality in Geauga County, Ohio-Status, 2009, and Changes During 1978-2009}

low concentrations that did not exceed health-based benchmarks. The only VOCs at concentrations above human-health benchmarks in Geauga County that were documented as part of this study were those found at areas of localized chemical releases investigated by Ohio EPA and described in the earlier section Water-Quality Issues Identified in Previous Investigations (fig. 11).

Iron and manganese.-The SMCL exceedance frequencies for iron and manganese were much greater in Geauga County than in Ohio as a whole (Ohio Environmental Protection Agency, 2012b, table M-4B) or elsewhere in the United States (fig. $14 F$ and $G$ ). This is likely due to the naturally occurring reducing geochemical conditions in the county aquifers that will be discussed in a later section of the report titled Factors Affecting Contaminant Occurrence and Constituent Concentrations in Groundwater.

\section{Occurrence of Methane in Groundwater}

The occurrence of dissolved natural gas in Geauga County aquifers has neither been previously evaluated by the USGS nor examined by any of the previous water-quality studies summarized by Jagucki and Darner (2001). The main component of natural gas typically is methane, which is flammable and can cause an explosion hazard when the gas is released to air as water is pumped from depth to the low-pressure environment at land surface. The possibility that methane is present in groundwater produced by some water wells in the county became a concern following the investigation by ODNR-MRM (2008b) of a methane release related to oil and gas drilling in Bainbridge Township that caused an explosion in one house (fig. 11, site 9). During the course of their investigation, ODNR-MRM interviewed local residents and water well drillers, examined records for the nearby Bainbridge Police Department well, and collected dissolved gas samples from several wells in the neighborhood affected by the explosion. ODNR-MRM personnel concluded that "the occurrence of natural gas in groundwater for wells developed in the Berea-Bedford ${ }^{6}$ sequence is common in Geauga County."

Methane gas is colorless, tasteless, and odorless. Signs that methane may be present in well water include popping or spurting of water at the tap or milky-looking water. No

\footnotetext{
${ }^{6}$ The Bedford Shale underlies the Berea Sandstone. Water well drillers frequently drill through the Berea Sandstone into the underlying Bedford Shale "to add storage capacity to domestic water wells" (Ohio Department of Natural Resources, 2008b, p. 24).
}

adverse health effects have been linked to the drinking of or bathing in well water that contains methane, although extensive research on this topic has not been done (Minnesota Department of Health, 2011). The primary hazard posed by methane is that it is highly flammable. Running tapwater in a home can allow methane dissolved in groundwater to come out of solution as gas bubbles and accumulate in the air within the home. Methane can explode if it reaches a concentration of 5 percent by volume and an ignition source (such as a spark from an electrical outlet, well pump, pilot light, or match) is present. Accumulation of gas is most likely to occur in a basement, utility room, or bathroom where large quantities of water are used (Eltschlager and others, 2001).

To evaluate the frequency of water wells that produce natural gas in the county in 2009, the USGS (1) screened 16 wells across the county for combustible gas fraction at the wellhead and in the headspace of water samples and (2) analyzed samples for dissolved gases in which combustible gas was detected or in which exsolving gases were observed during sampling. Combustible gas was not detected immediately below the well cap at any of the 16 wellheads screened by USGS personnel in 2009. Yet when water was pumped from each well and the air above the water (headspace) in a closed container was analyzed, the headspace of three samples (19 percent) was found to contain detectable combustible gas ( 0.10 to 0.40 percent by volume) (table 6 ). All three detections were in wells tapping the Cuyahoga Group or the Berea Sandstone, and these detections were all less than the lower explosive limit of 5 percent by volume. Laboratory analyses of methane concentrations for these three wells ranged from 0.0065 to $1.88 \mathrm{mg} / \mathrm{L}$ (table 6 ). The owner of well GE-126 reported that the well had produced gas since it was drilled in the 1970s and that the quantity of gas in the well water had declined over time. The other two well owners did not indicate that they were aware of methane in their wells. The maximum methane concentration of $1.88 \mathrm{mg} / \mathrm{L}$ was slightly greater than the maximum methane concentration measured in residential wells following the Bainbridge Township gas release in 2007 (measurements did not begin until after the house explosion) but was substantially less than methane concentrations that have been measured in residential wells in other study areas, including large regions of New York and West Virginia (table 7). 
Table 6. Dissolved gas concentrations in selected groundwater samples from domestic wells, Geauga County, Ohio, June 2009. [mg/L, milligrams per liter; $\mathrm{CH}_{4}$, methane; $\mathrm{CO}_{2}$, carbon dioxide; $\mathrm{N}_{2}$, nitrogen gas; $\mathrm{O}_{2}$, oxygen; Ar, argon. Replicate analyses are shown for each well]

\begin{tabular}{|c|c|c|c|c|c|c|c|c|c|c|}
\hline \multirow{2}{*}{$\begin{array}{l}\text { Well } \\
\text { name }\end{array}$} & \multirow{2}{*}{$\begin{array}{l}\text { Date } \\
\text { collected }\end{array}$} & \multirow{2}{*}{$\begin{array}{c}\text { Time } \\
\text { collected }\end{array}$} & \multirow{2}{*}{ Township } & \multirow{2}{*}{ Aquifer } & \multirow{2}{*}{$\begin{array}{c}\text { Combustible } \\
\text { gas in } \\
\text { headspace, } \\
\text { percent by } \\
\text { volume }\end{array}$} & \multicolumn{5}{|c|}{ Dissolved gas concentration (mg/L) } \\
\hline & & & & & & $\mathrm{CH}_{4}$ & $\mathrm{CO}_{2}$ & $\mathbf{N}_{2}$ & $\mathbf{O}_{2}$ & $\mathrm{Ar}$ \\
\hline GE-77 & $6 / 16 / 2009$ & 1800 & \multirow[b]{2}{*}{ Chester } & \multirow{2}{*}{$\begin{array}{c}\text { Cuyahoga } \\
\text { Group }\end{array}$} & \multirow[b]{2}{*}{$0.15^{\mathrm{a}}$} & 0.0071 & 33.8 & 24.56 & 0.3 & 0.8365 \\
\hline GE-77 & $6 / 16 / 2009$ & 1801 & & & & 0.0065 & 33.8 & 24.89 & 0.3 & 0.8429 \\
\hline GE-126 & $6 / 17 / 2009$ & 1101 & Parkman & $\begin{array}{l}\text { Berea } \\
\quad \text { Sandstone }\end{array}$ & 0.40 & 0.9918 & 19.1 & 21.29 & 0.3 & 0.7749 \\
\hline GE-147 & $6 / 16 / 2009$ & 1400 & \multirow{2}{*}{ Middlefield } & \multirow{2}{*}{$\begin{array}{c}\text { Cuyahoga } \\
\text { Group }\end{array}$} & \multirow{2}{*}{0.10} & 1.85 & 15.4 & 25.38 & 0.3 & 0.8685 \\
\hline GE-147 & $6 / 16 / 2009$ & 1401 & & & & 1.88 & 15.4 & 25.57 & 0.3 & 0.8697 \\
\hline
\end{tabular}

${ }^{a}$ Combustible gas was detected, but percent combustible gas by volume at this well should be considered an estimate because the instrument was not holding calibration well at the time of this reading.

Table 7. Studies of dissolved methane in residential water wells (modified from Bair and others, 2010, p. 3-133).

[mg/L, milligrams per liter]

\begin{tabular}{|c|c|c|c|}
\hline Likely origin of methane (reference) & Location & $\begin{array}{l}\text { Number } \\
\text { of wells } \\
\text { sampled }\end{array}$ & $\begin{array}{l}\text { Maximum } \\
\text { methane } \\
\text { concentration } \\
(\mathrm{mg} / \mathrm{L})\end{array}$ \\
\hline Overpressurized gas well (Bair and others, 2010) & $\begin{array}{l}\text { Bainbridge Township, } \\
\text { Geauga County, Ohio }\end{array}$ & 73 & $1.04^{\mathrm{a}}$ \\
\hline $\begin{array}{l}\text { Leakage from oil and gas production well plus } \\
\text { a shallow microbial source } \\
\text { (Van Stempvoort and others, 2005) }\end{array}$ & $\begin{array}{l}\text { Lloydminster, } \\
\text { Alberta, Canada }\end{array}$ & 14 & 26 \\
\hline $\begin{array}{l}\text { Oil and gas production along fault zone } \\
\text { (Agency for Toxic Substances and Disease } \\
\text { Registry, 2003) }\end{array}$ & $\begin{array}{l}\text { North Royalton, } \\
\text { Cuyahoga County, Ohio }\end{array}$ & 9 & 11 \\
\hline $\begin{array}{l}\text { Underground natural gas storage field } \\
\text { (Breen and others, 2007) }\end{array}$ & $\begin{array}{l}\text { Tioga Junction, Tioga } \\
\text { County, Pennsylvania }\end{array}$ & 39 & 44.8 \\
\hline $\begin{array}{l}\text { Thermogenic methane in underlying saline ground- } \\
\text { water and brines and some microbial methane } \\
\text { from reducing (methanogenic) groundwater } \\
\text { environments (Heisig and Scott, 2013) }\end{array}$ & $\begin{array}{l}\text { South-central } \\
\text { New York State }\end{array}$ & 66 & 55 \\
\hline Coal beds, coal mining (Mathes and White, 2006) & 43 counties, West Virginia & 170 & 68.5 \\
\hline
\end{tabular}




\section{Groundwater Quality in Geauga County, Ohio-Status, 2009, and Changes During 1978-2009}

To prevent the accumulation of gas in a well, the U.S. Department of the Interior, Office of Surface Mining advises that a vented cap be used. If methane is suspected in a well, a water well professional can provide advice on methods to vent the pressure tank associated with the well. Wells like those sampled in Geauga County, with dissolved methane concentrations less than $10 \mathrm{mg} / \mathrm{L}$, present no immediate danger but do require periodic monitoring to see whether methane concentrations are changing over time (Eltschlager and others, 2001). If methane is suspected in a well, the local fire department can test the levels of methane inside the home when water is running. The level of risk can vary with the amount of ventilation, amount of water running, and air pressure on the day the test is done. As an additional precaution, a methane detector can be purchased that mounts on a wall and triggers an alarm if dangerous levels of gas have accumulated. Finally, the sealing of all unused wells located in home basements (or unused wells located outside but still connected by plumbing to the house) may protect a home from migration of methane into the house (Eltschlager and others, 2001). Well sealing generally involves removing the well casing and screen (if present) and filling the open hole with grout. ODNR recommends that the work be done by an experienced registered drilling contractor. A well sealing report must be submitted to ODNR, Division of Water, and to the Geauga County Health District.

\section{Changes in Water Quality Over Time}

Groundwater-quality data collected by the USGS in 1978, 1980, 1986, 1999, and 2009 from the four primary aquifers in Geauga County (appendix table 4-1) were compared to evaluate changes in water quality over time. Ohio EPA's public-supply data were not considered in this analysis. Although the same USGS laboratory was used over time and collection methods employed by USGS field personnel were largely consistent, some factors have changed over time, introducing variability that affects statistical analysis and interpretation: the list of constituents analyzed has not been consistent through the years, the filtering (or not filtering) of samples prior to analysis has not been consistent, and instrumentation, analytical methods, and reporting levels have changed over the years for some constituents. After consideration of these factors, the properties and constituents listed in tables 8 and 9 were considered comparable for comparison of temporal data and are the ones used in statistical and graphical analyses summarized below. Two different statistical tests were employed to compare constituent concentrations because a change in well-selection strategy in recent years resulted in two types of water-quality datasets: (1) a subset of USGS data consisting of samples from wells that were able to be resampled, 1986 to 1999 and 1999 to 2009 , and (2) the entire dataset of samples from a generally variable set of wells, 1978-2009 (appendix table 4-1). Graphical techniques were used to compare detection frequencies and (or) concentrations of constituents with more than 50 percent nondetects because confounding factors may bias computations of statistical significance. A brief description of the two statistical tests used and the advantages and disadvantages of each test are discussed in the Methods section of the report.

\section{Changes in Water Quality, 1986 to 2009 and 1999 to 2009 , in Resampled Wells}

The 16 groundwater samples collected by the USGS in 2009 were drawn from wells that had been previously sampled in 1999. Eleven of the 16 wells had also been sampled in 1986 (table 3, appendix table 4-1). Data from resampled or "paired" wells were compared, two years at a time, using the nonparametric Wilcoxon signed-rank test. Data from multiple aquifers were grouped together for this statistical test.

Results of the paired-well tests are listed in table 8 for frequently detected constituents (constituents detected in more than 50 percent of samples). Because the Wilcoxon signed-rank test only determines whether concentration values measured in two years are statistically different (p-value $<0.05$ ), data for constituents deemed different were then evaluated graphically (fig. 15) to determine whether concentrations had increased or decreased with time. (Constituent concentrations that were the same in both years would plot on the red line [1:1 slope] in figure 15 . The further a data point plots away from the red line, the greater the change in concentration between years.) Few constituents had significant changes in concentration between 1986 and 1999 (table $8 A$ ); only chloride concentrations and the ratios of chloride to bromide significantly increased. Between 1999 and 2009, however, concentrations of several constituents (dissolved oxygen, specific conductance, magnesium, alkalinity, silica, $\mathrm{pH}$, bromide, organic carbon, and ammonia) changed significantly (table $8 B$ ). Evaluation of measurement variability using quality-control data (appendix 2) suggests that apparent changes over time in specific conductance and silica concentrations may actually be caused by laboratory bias rather than by actual changes in constituent concentrations in groundwater.

What do the observed changes in concentration indicate with regard to drinking-water quality? Health-based or aesthetically based benchmarks have been established for three of the constituents that had a statistically significant change in concentration between either 1986 and 1999 or 1999 and 2009: chloride, ammonia, and $\mathrm{pH}$ (denoted by bolded text in table 8; benchmarks for each constituent are listed in appendix table 4-1). Chloride concentrations increased from 1986 to 1999 (table $8 A$ ), moving toward the aesthetically based benchmark of $250 \mathrm{mg} / \mathrm{L}$ of chloride in drinking water, although the maximum concentration in the resampled wells was $28.8 \mathrm{mg} / \mathrm{L}$ (fig. $15 \mathrm{~A}$ ) - still quite removed from the concentration at which chloride will impart a salty taste to water. Furthermore, chloride concentrations did not continue 
Table 8. Statistical test results for differences in constituent concentrations between years in samples from wells that were able to be resampled by the U.S. Geological Survey in Geauga County, Ohio, from 1986 to1999 or 1999 to 2009.

[n, number of samples ( $\mathrm{n}$ is equal to the number shown in the column heading unless otherwise indicated). Properties and constituents included in table are those that have been consistently analyzed for over time and that have had detectable concentrations at least 50 percent of the time. Bolded constituents are those for which a health-based or aesthetically based benchmark has been established (U.S. Environmental Protection Agency, 2006, 2009). The Wilcoxon signed-rank test was used to evaluate differences in concentration distributions between years. Highlighted values (orange or blue) are statistically different at the 95 -percent confidence level ( $p$-value $<0.05$ ). Direction of change (increase or decrease in concentration over time) was determined by visually evaluating scatterplots of the data shown in fig. 15]

\section{A 1986 to 1999}

\begin{tabular}{|c|c|c|}
\hline Properties or constituents & $\begin{array}{c}\text { p-value } \\
(n=11)\end{array}$ & $\begin{array}{l}\text { Direction of change } \\
\text { in concentration }\end{array}$ \\
\hline Dissolved oxygen $^{1}$ & 0.1878 & \multirow{13}{*}{$\begin{array}{c}\text { No significant } \\
\text { change }\end{array}$} \\
\hline Specific conductance ${ }^{1}$ & 0.7211 & \\
\hline Magnesium & 0.6247 & \\
\hline Alkalinity & 0.1190 & \\
\hline Silica & 0.1076 & \\
\hline pH & 0.0726 & \\
\hline Bromide & 0.9287 & \\
\hline Ammonia & 0.6875 & \\
\hline Hardness & 0.5312 & \\
\hline Calcium & 0.5333 & \\
\hline Sodium & 0.7002 & \\
\hline Potassium & 0.4648 & \\
\hline Sulfate & 0.7969 & \\
\hline Chloride $^{2}$ & 0.0010 & \multirow{2}{*}{ Increased } \\
\hline Chloride to bromide ratio & 0.0020 & \\
\hline Dissolved solids & 0.9645 & \multirow{3}{*}{$\begin{array}{c}\text { No significant } \\
\text { change }\end{array}$} \\
\hline Iron & 0.1230 & \\
\hline Manganese & 0.5771 & \\
\hline
\end{tabular}

\footnotetext{
${ }^{1}$ For dissolved oxygen, $n=8$; for specific conductance, $n=10$.
}

${ }^{2}$ The statistical test used for this analysis is more sensitive to changes in individual wells than the one used by Jagucki and Darner (2001), who found no significant change in chloride concentration from 1986 to 1999.
B 1999 to 2009

\begin{tabular}{lcc}
\hline Properties or constituents & $\begin{array}{c}\text { p-value } \\
\text { (n=16) }\end{array}$ & $\begin{array}{c}\text { Direction of change } \\
\text { in concentration }\end{array}$ \\
\hline Dissolved oxygen & 0.0005 & \\
Specific conductance ${ }^{3}$ & 0.0063 & Increased \\
Magnesium & 0.0385 & \\
Alkalinity & 0.0213 & \\
Silica & \\
pH & 0.0060 & \\
Bromide & 0.0020 & \\
Dissolved organic carbon & 0.0196 & \\
Ammonia & 0.0014 & \\
Hardness & 0.0005 & \\
Calcium & 0.1044 & \\
Sodium & 0.1439 & \\
Potassium & 0.1591 & \\
Sulfate & 0.1268 & \\
Chloride & 0.0739 & No significant \\
Chloride to bromide ratio & 0.0739 \\
Dissolved solids & 0.0979 \\
Iron & 0.7560 \\
Manganese & 0.4372 & \\
\hline & 0.5694 & \\
\hline
\end{tabular}

${ }^{3}$ Quality-control data suggest that apparent changes in specific conductance from 1999 to 2009 may be within the range of expected sensor and sampling accuracy and may not represent an actual change in groundwater chemistry. Likewise, apparent changes in concentrations of silica from 1999 to 2009 may be the result of laboratory bias (change in recovery) and may not be caused by an actual change in groundwater chemistry. See appendix 2.

\section{What is a p-value?}

The p-value describes the statistical significance of the test result for a constituent, which in this report means the percent chance that the statistical test result occurred by chance if there really are no changes in constituent concentration with time. The smaller the p-value, the stronger the scientific evidence that constituent concentrations measured in different years are really different, or that constituent concentrations are really correlated to time (sampling year). For example, a p-value of 0.01 indicates that there is a 1 percent chance that the statistical test result occurred by chance alone (Helsel, 2005). For all statistical tests in this report, the result was deemed to be statistically significant if the p-value was less than 0.05 . 
$\boldsymbol{A}$

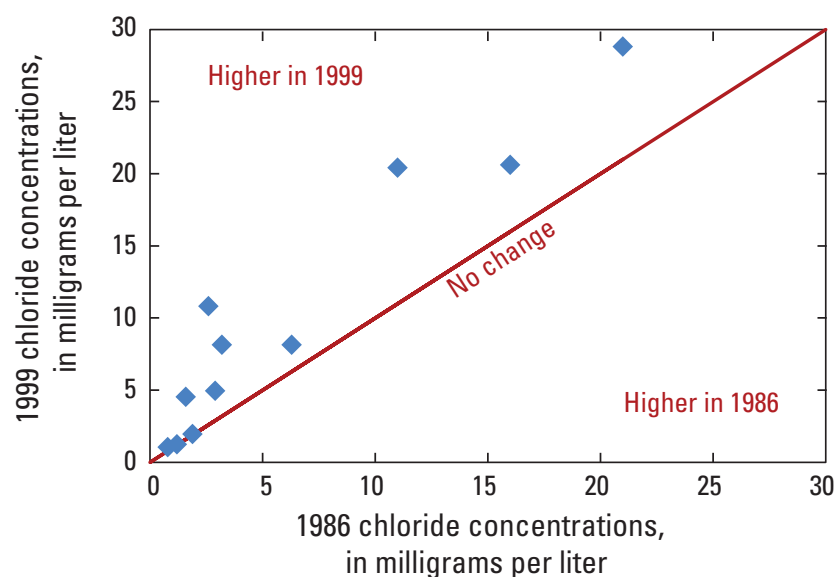

C

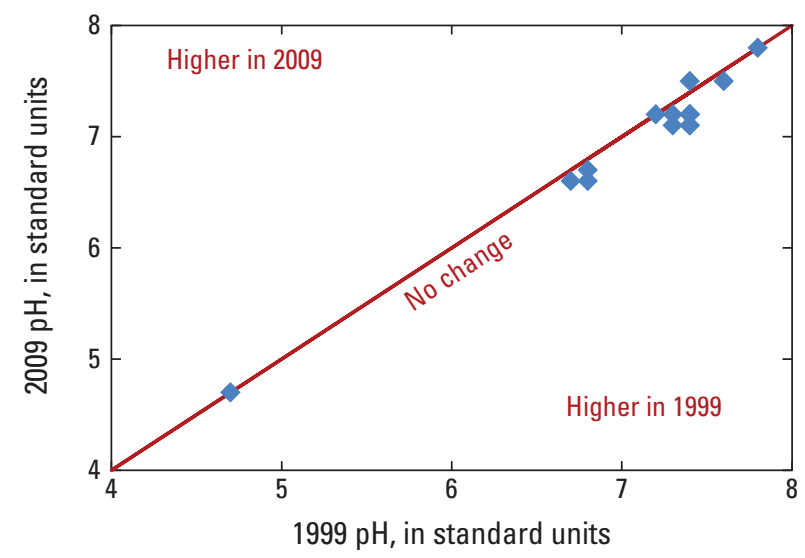

$\boldsymbol{E}$

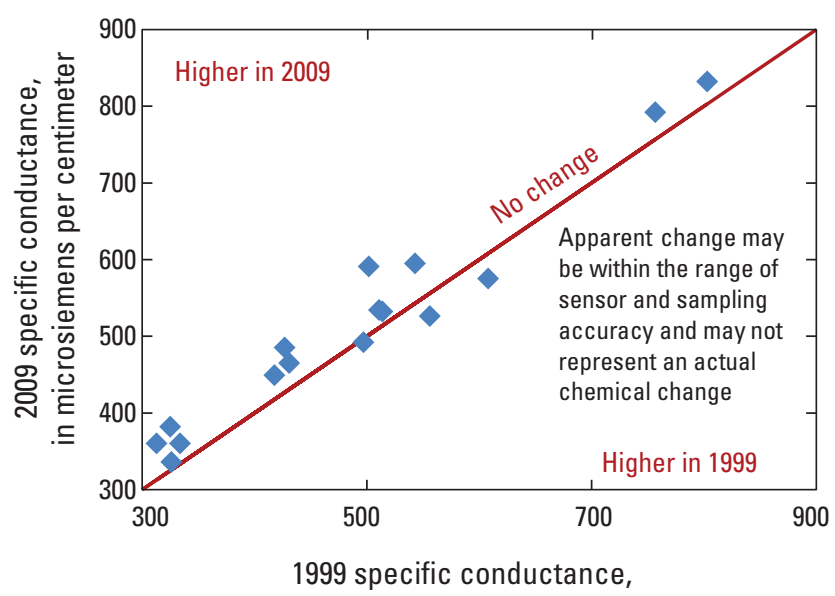

in microsiemens per centimeter
$\boldsymbol{B}$

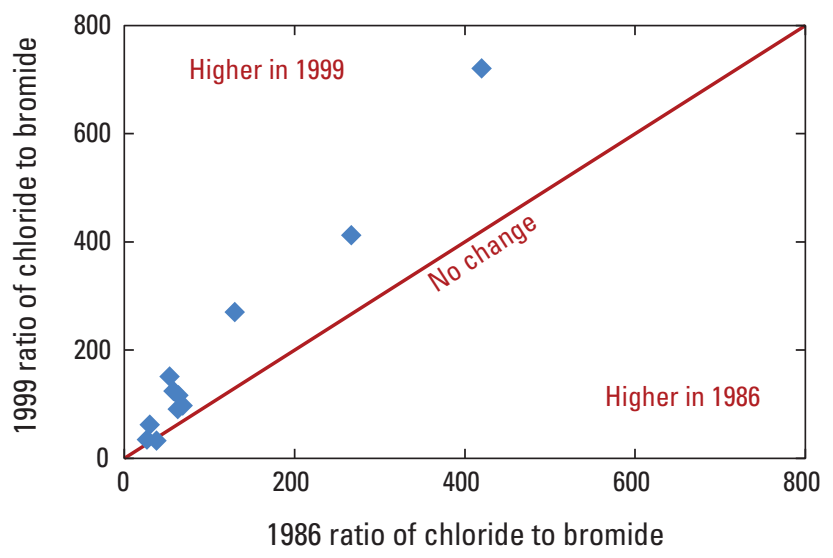

D

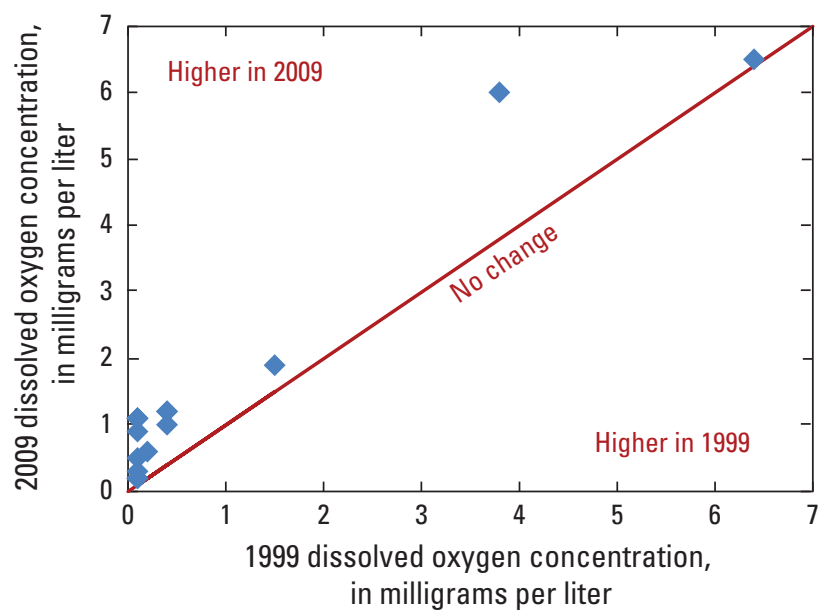

$\boldsymbol{F}$

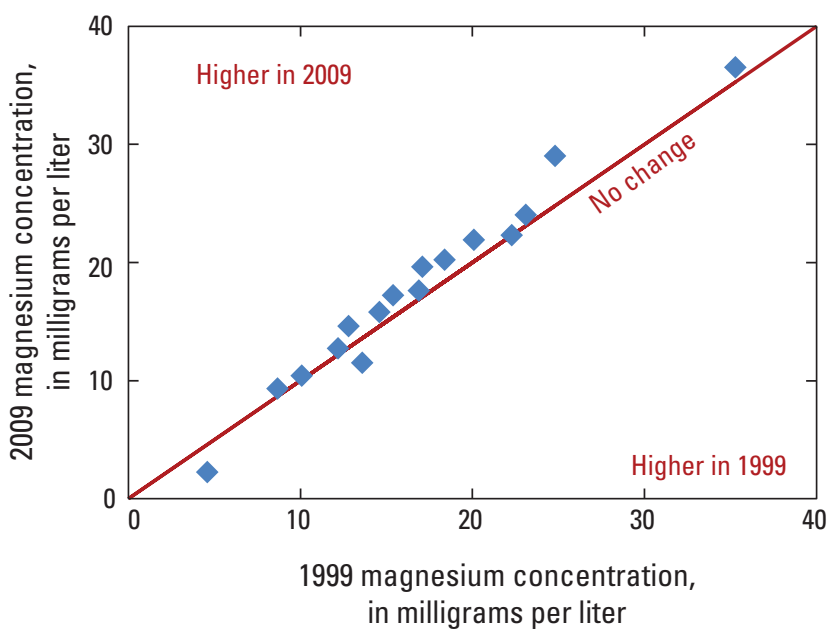

Figure 15. Properties and constituents with a statistically significant change in concentration from 1986 to 1999 or 1999 to 2009 in resampled wells, Geauga County, Ohio. 
$G$

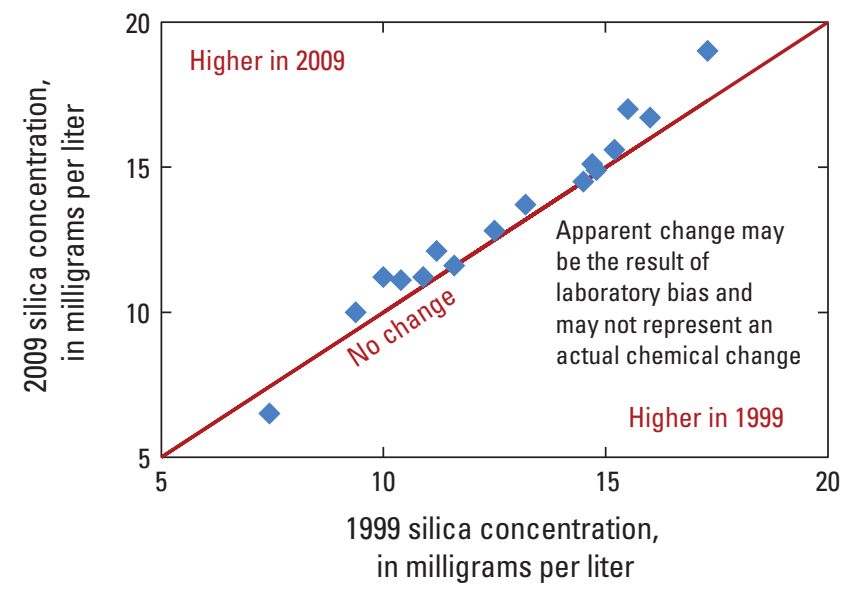

I

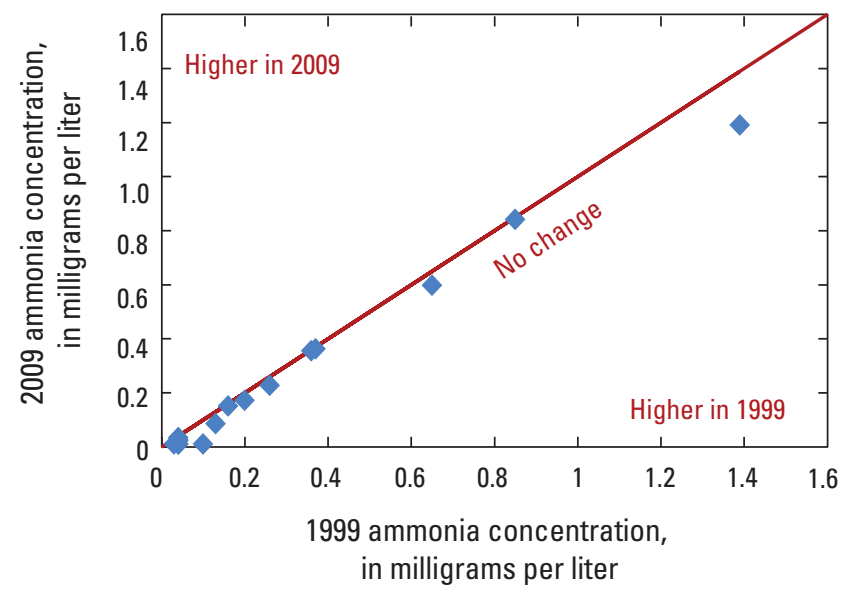

$\boldsymbol{K}$

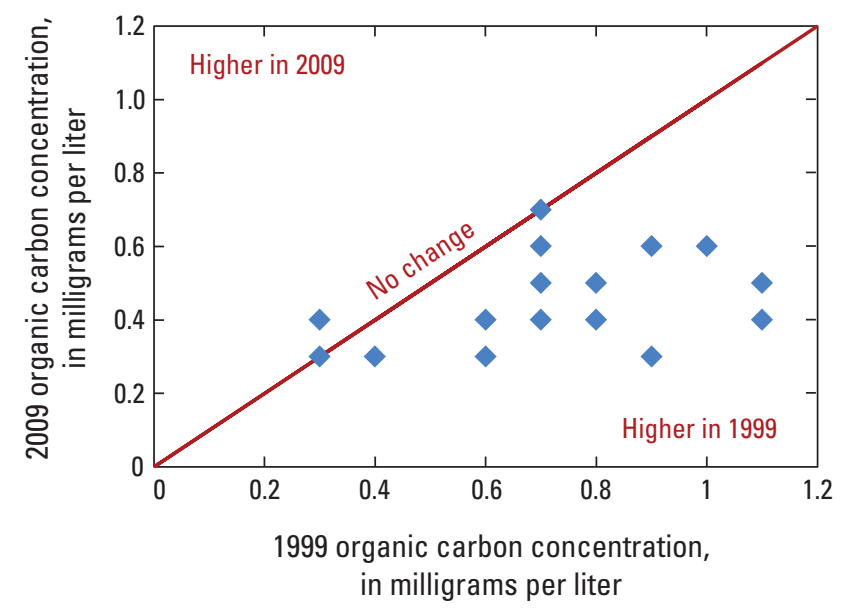

H

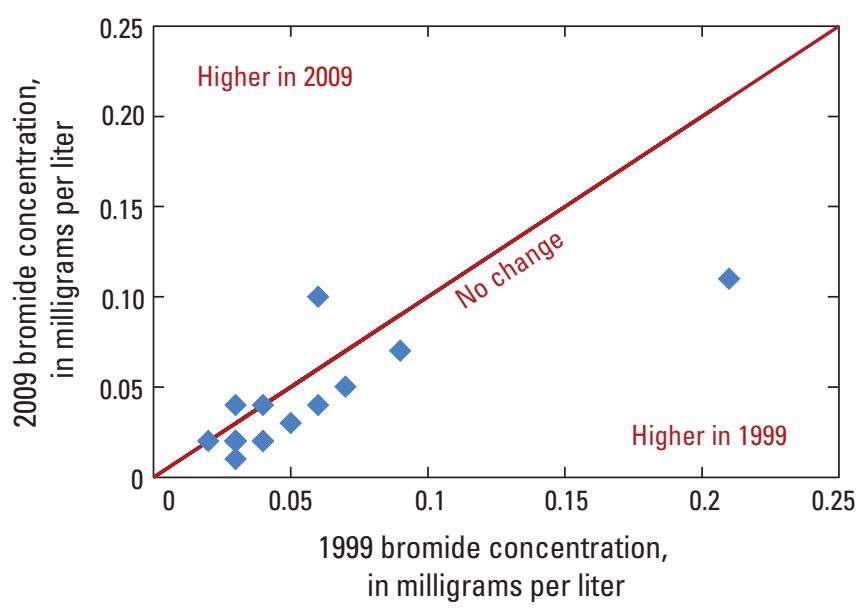

$J$

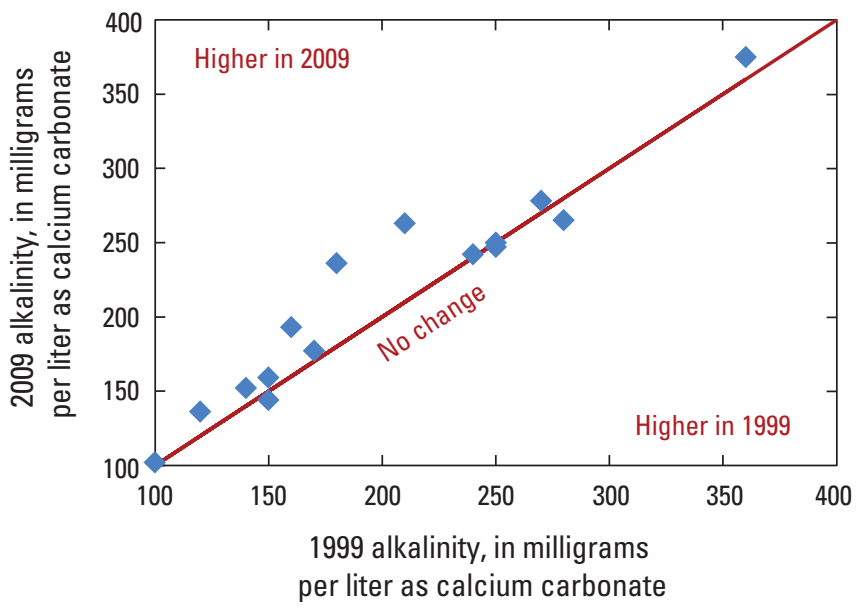

Figure 15. Properties and constituents with a statistically significant change in concentration from 1986 to 1999 or 1999 to 2009 in resampled wells, Geauga County, Ohio.-Continued 


\section{Groundwater Quality in Geauga County, Ohio-Status, 2009, and Changes During 1978-2009}

to increase from 1999 to 2009 . Ammonia concentrations decreased from 1999 to 2009 (table 8B, fig. 15I) and are thus moving farther away from the health-based benchmark of 30 $\mathrm{mg} / \mathrm{L}$ as $\mathrm{N}$ (the ammonia concentration at or below which there are not expected to be any adverse health effects over a lifetime of exposure). Lastly, the observed decrease in $\mathrm{pH}$ from 1999 to 2009 (table $8 B$ ) is a move in direction toward the lower aesthetically based limit (SMCL) of $6.5 \mathrm{pH}$ units, with one of the resampled wells already having a pH below this limit (fig. 15C). For the majority of wells, however, the decrease in $\mathrm{pH}$ is only of concern if changes in the same direction continue in subsequent years.

The observation of statistically significant changes in concentrations of some constituents between two sampling years does not necessarily indicate that these changes are human induced. Annual variations in precipitation cause variations in the amount of recharge to the groundwater system from year to year. For example, the increase in the amount of dissolved oxygen in samples from 1999 to 2009 is consistent with several years of above-normal annual precipitation preceding the 2009 sampling round (fig. 3), because atmospheric oxygen dissolved in precipitation is the source of dissolved oxygen to groundwater. As a result of fluctuations in annual precipitation amounts, concentrations of many groundwater constituents can fluctuate in response to influx of constituents from land surface, dilution of constituents in groundwater by infiltrating rainwater, or changes in groundwater flow rates that affect contact time between groundwater and aquifer minerals, thereby affecting mineral dissolution rates. In contrast, a consistent trend in constituent concentrations over several years is of greater concern because it implies that some type of long-term environmental change (either natural or human induced) has affected water quality.

\section{Changes During 1978-2009 in Concentrations of Frequently Detected Constituents}

Water-quality data in Geauga County have been collected over a long period of time (1978-2009) relative to most other counties in Ohio. To utilize data from the entire period of record (rather than merely examine temporal changes between the most recent sampling rounds), a different statistical test had to be employed because a substantial amount of the water-quality data (appendix table 4-1) are not from resampled wells. It was not possible to sample the same group of wells during each sampling round because of (a) wells being destroyed or replaced over time, (b) changes in access permission from homeowners, or (c) changes in monetary resources, limiting the number of samples that could be analyzed during some years. Changes in constituent concentrations analyzed during three or more years between 1978 and 2009 were statistically evaluated by using the nonparametric Spearman's rho correlation test. The correlation coefficient produced by this test measures the strength of the association between sampling year (time) and constituent concentration (or how likely it is that concentration consistently increases or decreases as time increases). A benefit of the test is that temporal trends within each aquifer can be evaluated.

Statistical results (table 9) indicate that, at a 95-percent confidence level (p-value less than 0.05), the majority of constituents showed no consistent temporal trend in concentration. Dissolved oxygen, calcium, and sulfate concentrations and chloride:bromide ratios increased over time in one or more aquifers, while $\mathrm{pH}$ and concentrations of bromide and dissolved organic carbon decreased over time. Many of these results are similar to those observed between 1986 and 1999 or between 1999 and 2009 in resampled wells (table 8).

\section{What do correlation coefficients mean?}

A correlation coefficient (rho) measures the strength of the monotonic relation between two constituents or parameters. The closer the value of rho to 1 or -1 , the stronger the correlation. A positive correlation coefficient means that as the concentration of one constituent increases, so does the concentration of the other. A negative correlation coefficient means that as the concentration of one constituent increases, the concentration of the other constituent decreases. All correlations presented were statistically significant at a 95-percent confidence interval ( $p$-value $<0.05$ ). For the purposes of this report, the strength of the correlation between two properties or constituents is defined as follows, based on rho: strong, rho is greater than 0.75 ; good, rho is 0.50 to 0.75 ; fair, rho is 0.20 to 0.50 ; poor, rho is less than 0.20 ). 


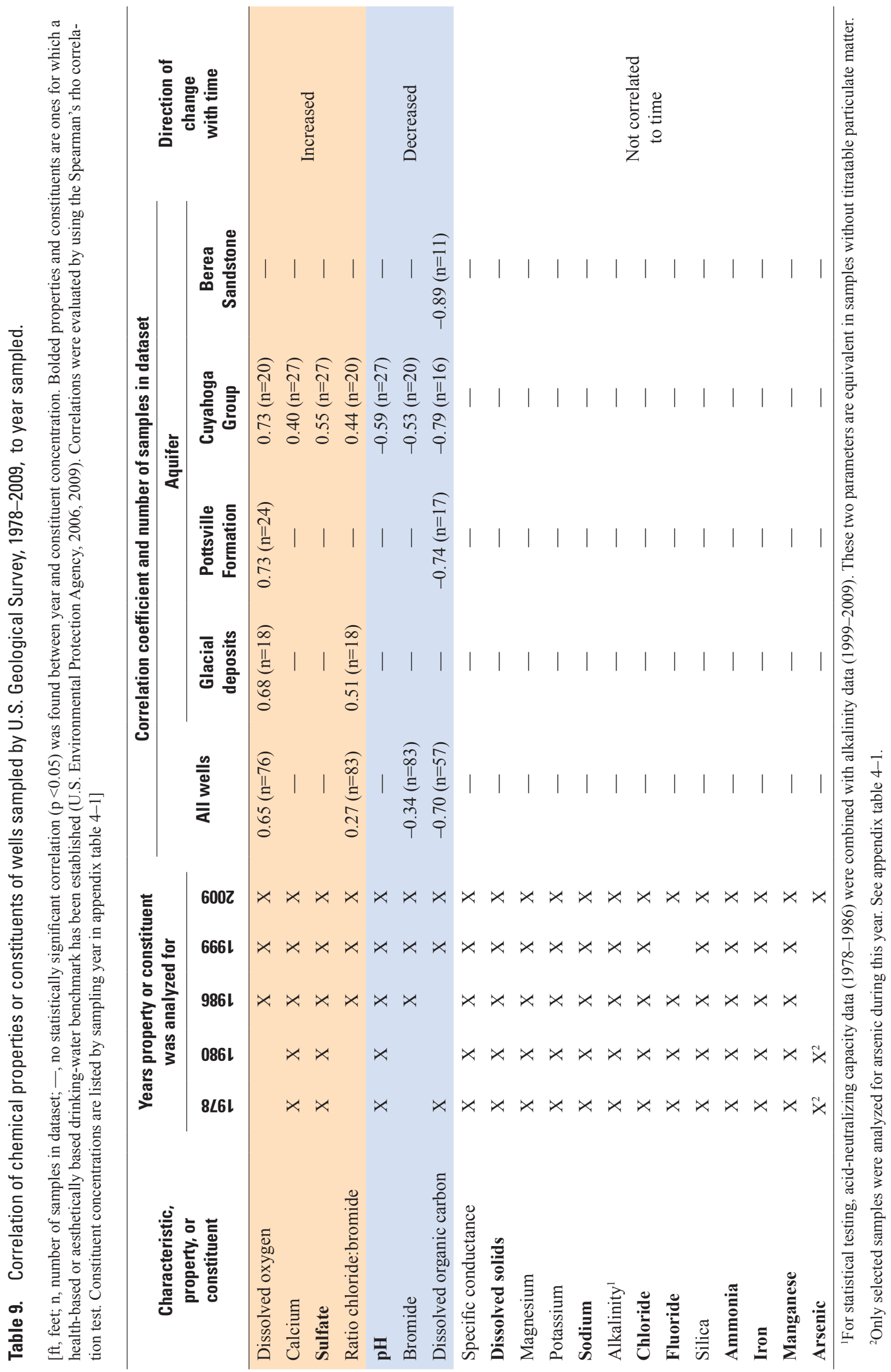




\section{Groundwater Quality in Geauga County, Ohio-Status, 2009, and Changes During 1978-2009}

Constituent concentrations in samples from the Berea Sandstone were largely unchanged over time (table 9). This is not surprising because the Berea Sandstone is the aquifer containing the oldest water (fig. 2) and thus is the aquifer least likely to be affected by human-induced (or natural) changes near land surface. In contrast, samples from the Cuyahoga Group had the greatest number of constituents with concentrations exhibiting temporal trends. Test results for temporal trends in the Cuyahoga Group do not appear to be biased by differences in construction characteristics of the wells sampled in different years because none of the following construction characteristics of Cuyahoga wells were correlated to sampling year at a statistically significant level $(p<0.05)$ : depth or elevation of well bottom, depth or elevation of top of open interval, or depth to water.

Of the constituents found to be statistically correlated to time, 1978-2009, only sulfate and $\mathrm{pH}$ have an drinkingwater benchmark (shown as bolded parameter names in table 9) against which to gage direction of change. As previously stated, the decrease in the $\mathrm{pH}$ is a move in direction toward the lower SMCL of $6.5 \mathrm{pH}$ units. Temporal changes in concentrations of sulfate in the Cuyahoga Group were illustrated graphically by using boxplots (fig. 16).

Boxplots allow visual comparison among years of median concentration, interquartile range (the distribution of the data that lie between the 75 th percentile and the 25 th percentile), and the total range of measured values. The boxplots show that median sulfate concentrations increased during 1986-2009.

Despite this trend, the maximum sulfate concentration in 2009 (140 mg/L) was still considerably below the aesthetically based benchmark of $250 \mathrm{mg} / \mathrm{L}$.

Temporal changes in concentrations of bromide and dissolved organic carbon and in chloride:bromide ratios (constituents or ratios that do not have health-based or aesthetically based benchmarks but that were prevalent enough to be detected in a dataset of all wells [table 9]) are also graphically shown by means of boxplots (fig. 17). Possible reasons for these trends are discussed in the Factors Affecting Contaminant Occurrence section of the report.

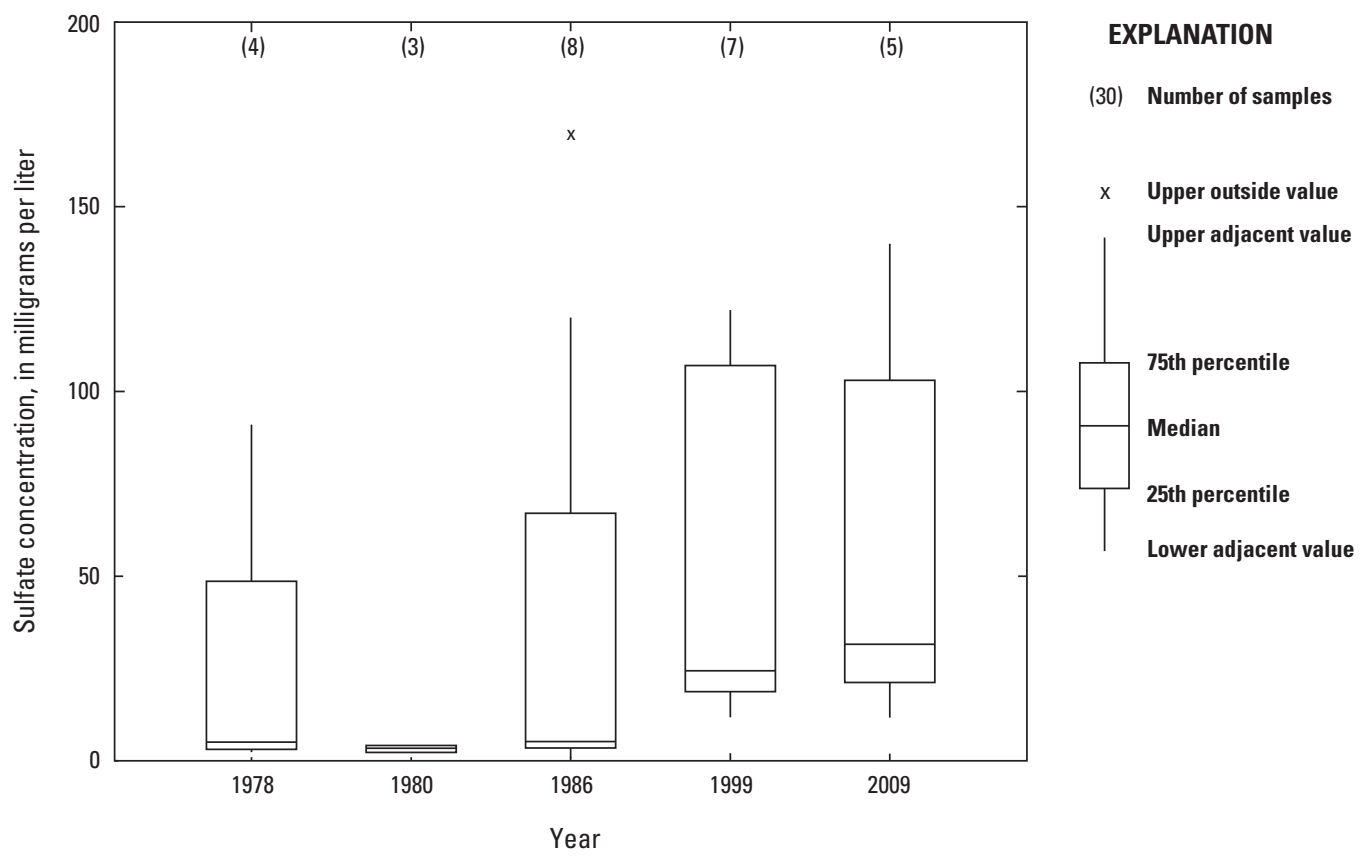

Figure 16. Changes in sulfate concentrations, 1978-2009, in samples from the Cuyahoga Group, Geauga County, Ohio. 

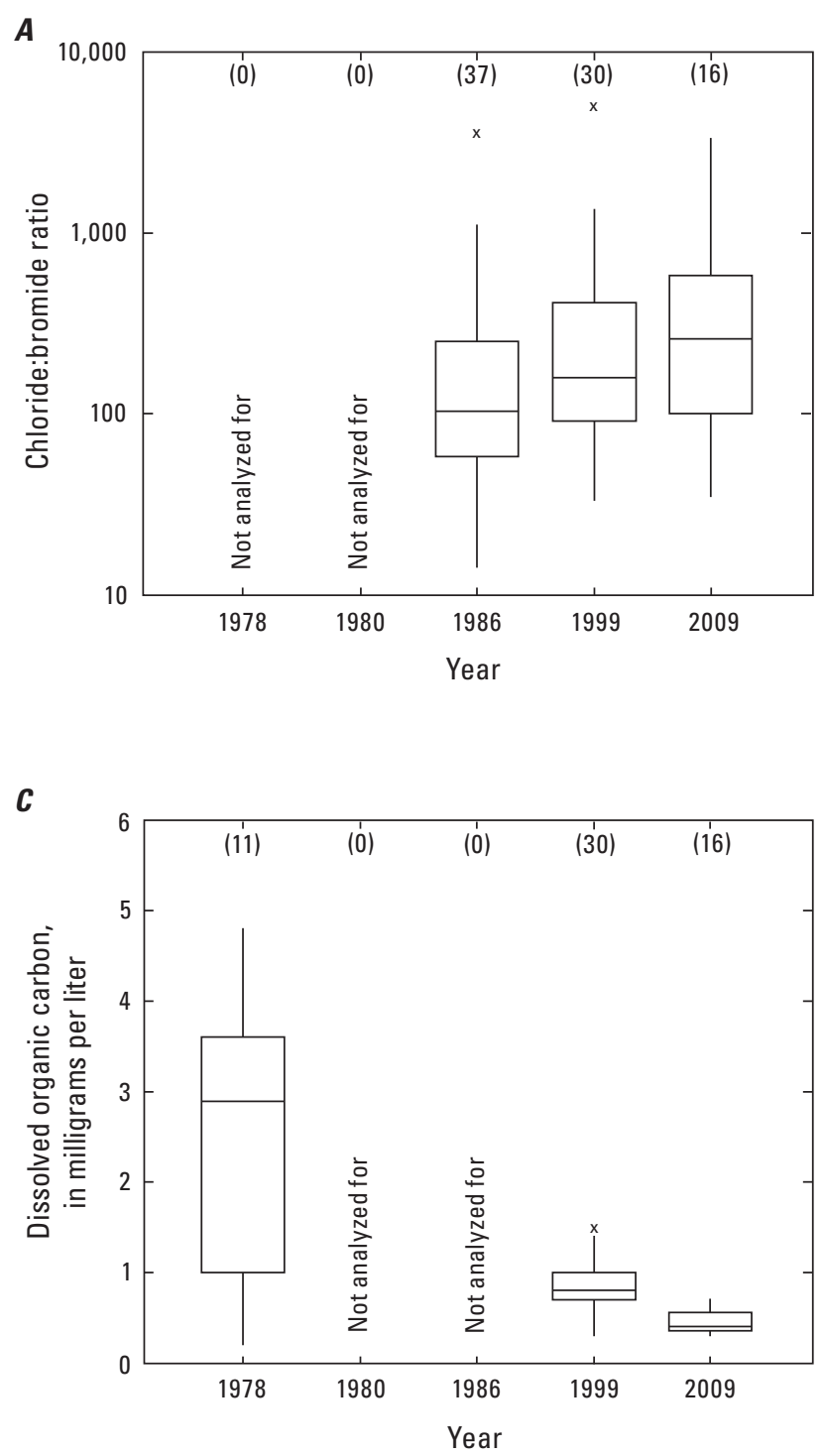

$B$

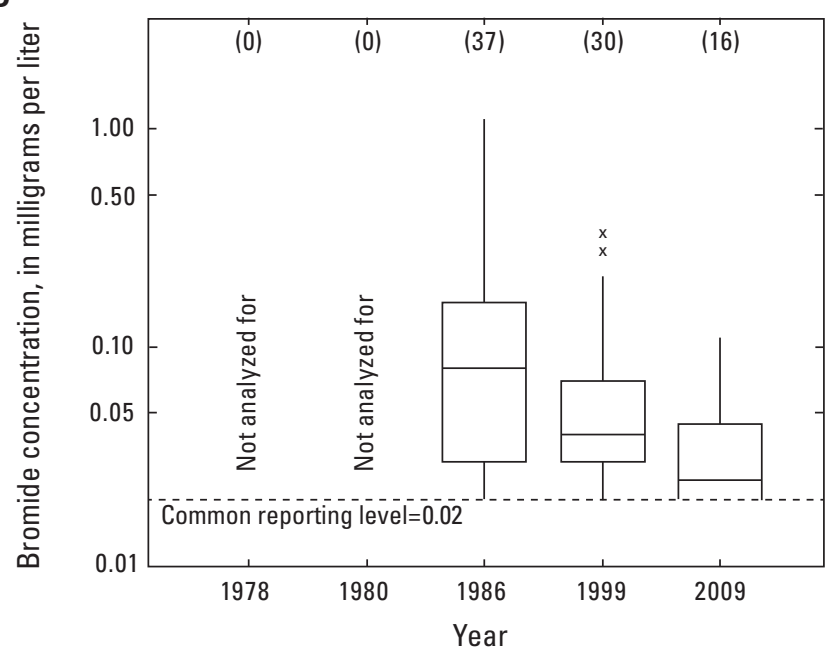

\section{EXPLANATION}

(30) Number of samples

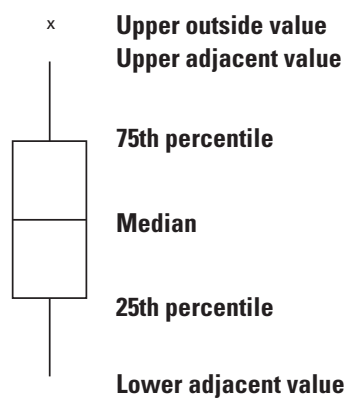

Figure 17. Changes of selected constituent ratios and concentrations in all wells sampled by the U.S. Geological Survey in Geauga County, Ohio, 1978-2009: A, Chloride:bromide ratios. B, Concentrations of bromide. C, Concentrations of dissolved organic carbon.

\section{Changes Over Time Of Constituents With Infrequent Detections}

Total coliform bacteria, nitrate, orthophosphate, and sulfide were analyzed for during three or more years from 1978 through 2009 from an inconsistent set of wells but had more than 50 percent nondetects when censored to a common reporting level. For these constituents, changes over time were evaluated by comparing the detection frequency each year and (or) by comparing concentrations in resampled wells.

The detection frequency of total coliform bacteria was higher in 1999 ( 53 percent) than in 2009 (33 percent) for all wells sampled in the county (appendix table 4-1). After the relatively high detection frequencies for bacteria measured in 1999, owners of wells in which bacteria were detected were advised to treat their wells with shock-chlorination to kill the bacteria; this might have contributed to the difference in detections of total coliforms from 1999 to 2009. Concentrations of total coliforms at individual wells were compared for the 16 wells sampled in 1999 that were resampled in 2009. Total coliform bacteria were detected at a concentration greater than or equal to 1 colony-forming unit per $100 \mathrm{~mL}$ of water in 11 of the 16 wells in either 1999 or 2009, but in both years in only 2 wells (fig. 18). Of the two wells with detections both years, total coliforms increased from 1999 to 2009 in only one well (GE-141). 


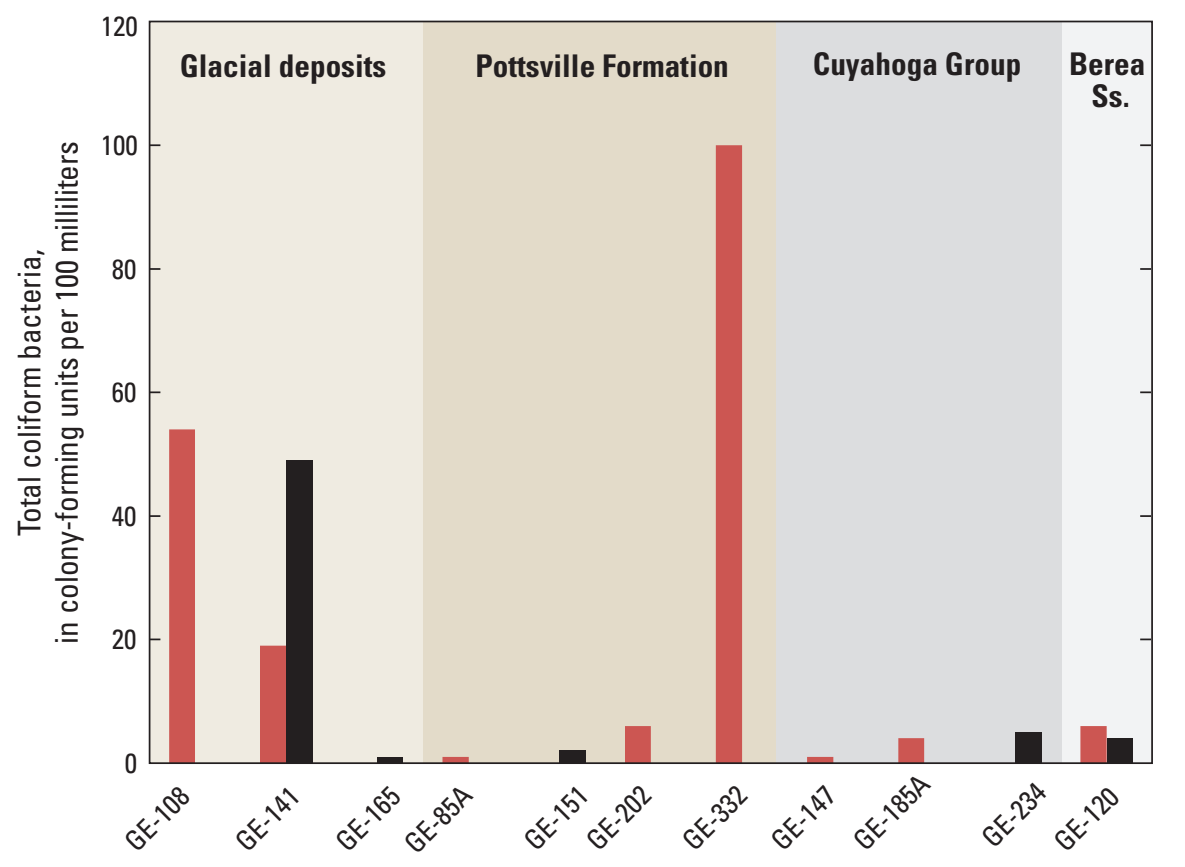

\author{
EXPLANATION \\ Years sampled \\ 1999 \\ - 2009
}

Figure 18. Comparison of total coliform concentrations in 1999 and 2009 in samples from wells with at least one detection, Geauga County, Ohio. (Ss., sandstone.)

Wells with samples containing total coliforms

Because nitrate is detected much more frequently in wells producing water from the Pottsville Formation than in wells that tap other aquifers (fig. 19A), change over time was evaluated by comparing the nitrate detection frequency only in samples from the Pottsville Formation (fig. 19B). (This eliminates variability in detection frequency between years caused by sampling a different percentage of Pottsville wells each year.) Nitrate in groundwater is of interest because a health-based standard has been established for nitrate in drinking water and because human influences (such as application of fertilizer and biosolids, or failing septic systems) can be a source of nitrates to groundwater, along with natural sources. Although population has increased during each decade in Geauga County (fig. 4) (and presumably, so have human sources of nitrates), detections of nitrate (fig. 19B) have not consistently become more frequent over time.

The well assemblage sampled each year may also influence the detection frequency of orthophosphate in a given year, because orthophosphate was detected more frequently in wells tapping the Cuyahoga Group and the Berea Sandstone than in wells open to the Pottsville Formation and glacial deposits (fig. 20). To eliminate this potential bias, concentrations from wells that had detectable orthophosphate (greater than or equal to $0.01 \mathrm{mg} / \mathrm{L}$ ) in one or more years $(1986,1999$, or 2009) were examined by well (fig. 21). For these eight wells, detections of orthophosphate were more frequent in 2009 than in preceding years. Increases in orthophosphate detections are of interest because orthophosphate can indicate pollution from laundry wastewater, commercial cleaning wastes, sewage, or fertilizer (Hem, 1989).
Total sulfide was measured in only about one-third of the wells sampled by the USGS in 1986 and in all wells sampled in 1999 and 2009 (appendix table 4-1, fig. 22). Detection frequency of sulfide has increased in each subsequent year from 1986 through 2009 (fig. 22). To evaluate changes in concentration of sulfide over time, concentrations from wells that had detectable sulfide (greater than or equal to 0.01 $\mathrm{mg} / \mathrm{L}$ ) in 1999 and (or) 2009 were examined by well (fig. 23). Only data for 1999 and 2009 were compared because laboratory reporting levels were an order of magnitude higher in $1986(0.1 \mathrm{mg} / \mathrm{L})$ than in subsequent years $(0.01 \mathrm{mg} / \mathrm{L})$.

Of the 16 wells that were sampled in both 1999 and 2009, 10 had detectable sulfide $(\geq 0.01 \mathrm{mg} / \mathrm{L})$ in one or both years (fig. 23). Of these 10 wells, 60 percent showed an increase in sulfide concentration between 1999 and 2009. All wells tapping the Cuyahoga Group showed increases, while total sulfide concentrations in water from both of the Pottsville wells decreased. Sulfide concentrations are of interest because sulfide can combine with iron to form black iron sulfide particulates in water or pressure tanks or can form hydrogen sulfide that causes the undesirable rotten-egg smell.

In summary, detections of total coliform and nitrate have not become more frequent countywide from 1986 to 2009 , even though the county population has increased during this period; however, a few individual wells have shown increases in concentrations of these constituents. Orthophosphate and sulfide detections were more frequent in 2009 than in previous years. 

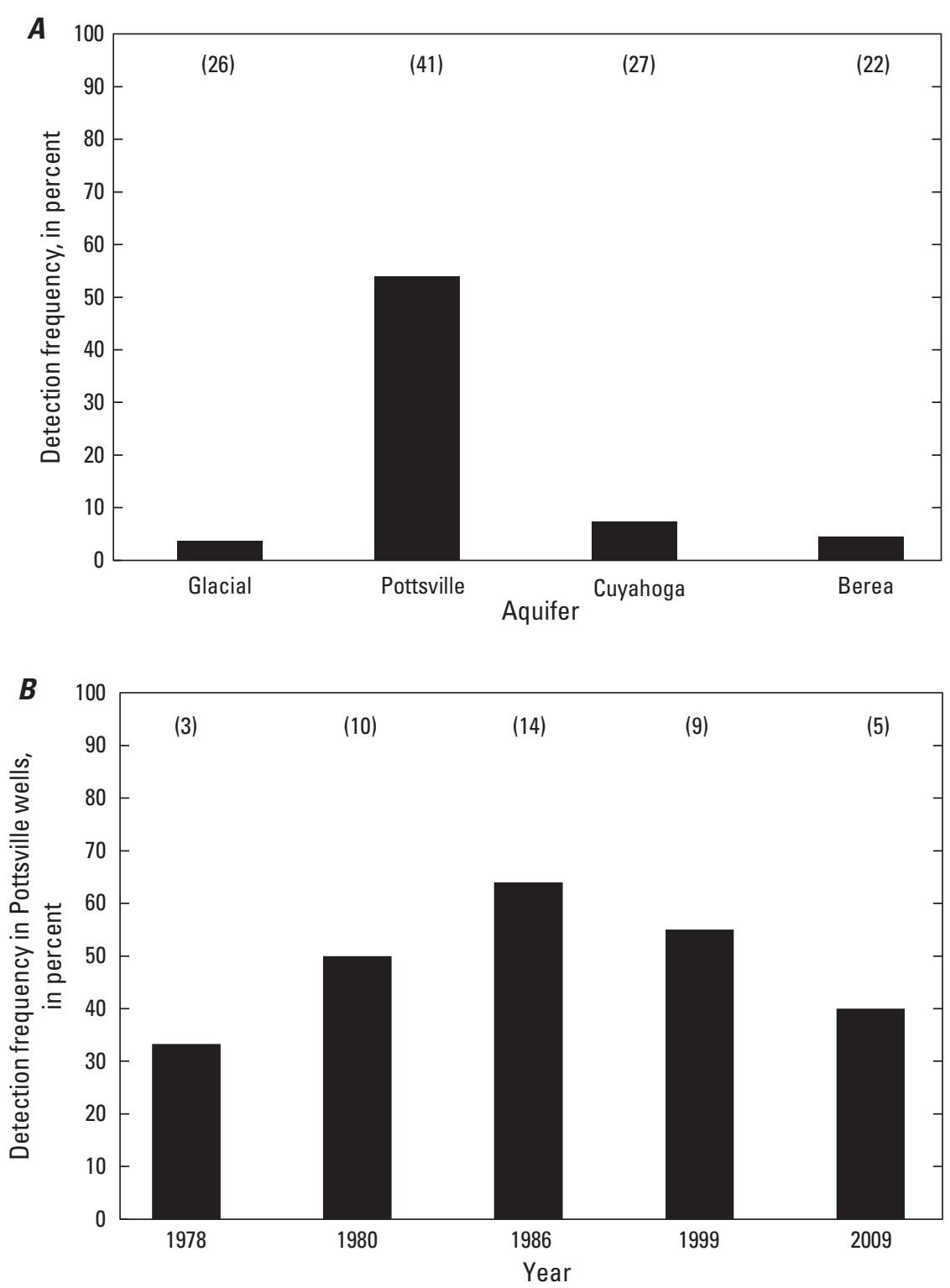

Figure 19. Detection frequency of nitrate in Geauga County, Ohio, 1978-2009, when censored to a common reporting level of 0.18 milligram per liter (number in parentheses denotes number of samples in each category). $A$, By aquifer. $B$, In samples from the Pottsville Formation.

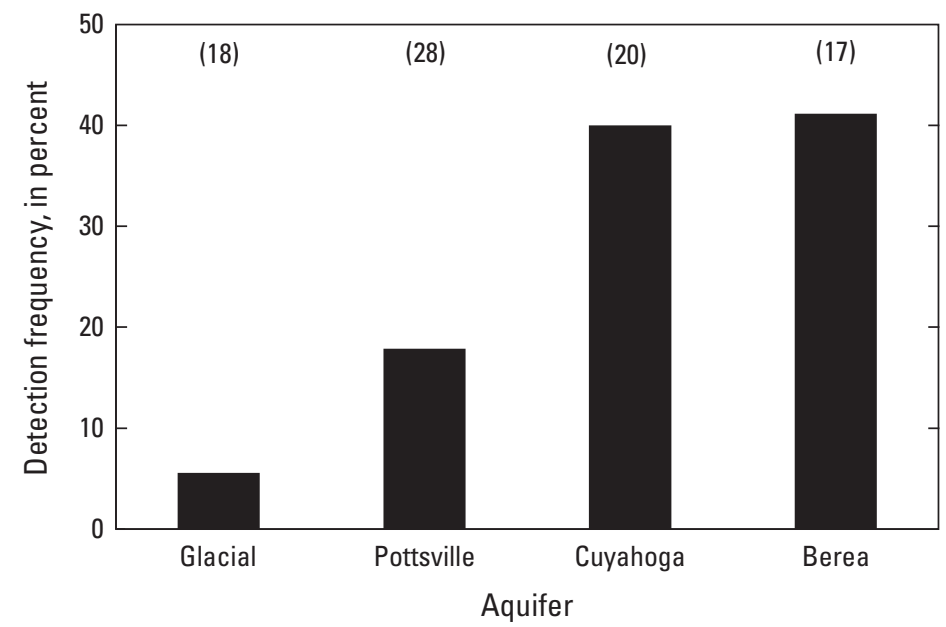

Figure 20. Detection frequency of orthophosphate in Geauga County, Ohio, by aquifer, 1986-2009, when censored to a common reporting level of 0.01 milligram per liter (number in parentheses denotes number of samples in each category). 


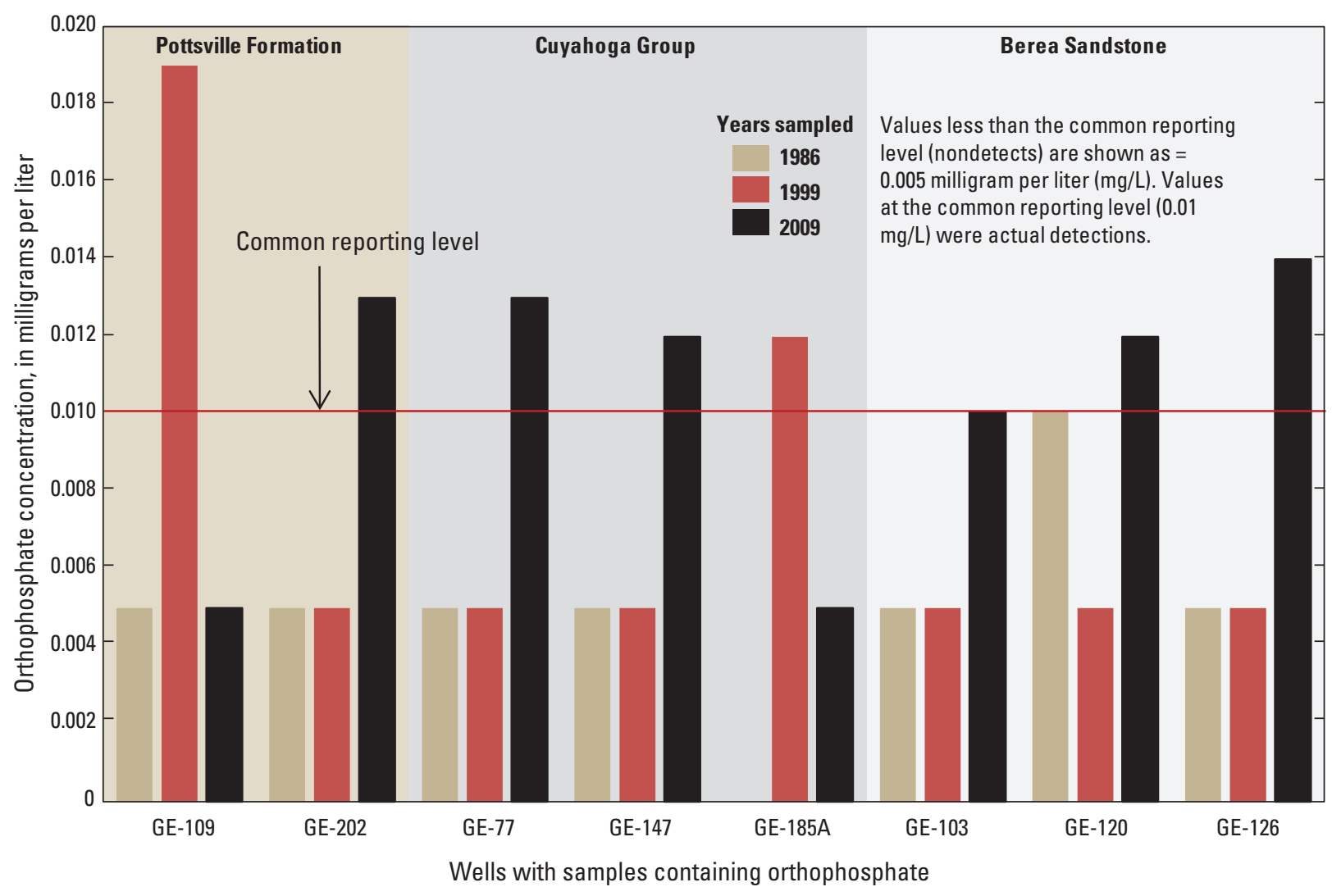

Figure 21. Orthophosphate concentrations, 1986-2009, for wells in Geauga County, Ohio, producing water with a concentration greater than or equal to 0.01 milligram per liter in one or more years. (Samples in 1999 were analyzed by Heidelberg University, Tiffin, Ohio. Samples in 1986 and 2009 were analyzed by the U.S. Geological Survey National Water Quality Laboratory.)

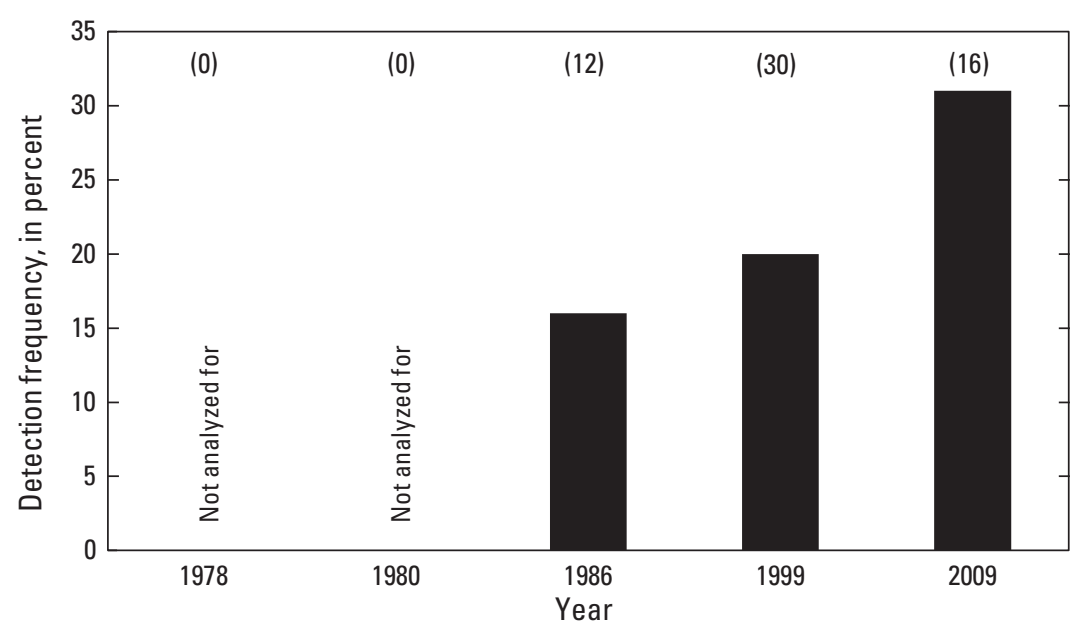

Figure 22. Detection frequency of total sulfide by year, Geauga County, Ohio, 1986-2009. (Detection frequency calculated by using a common reporting level of 0.1 milligram per liter. Number in parentheses denotes number of samples in category.) 


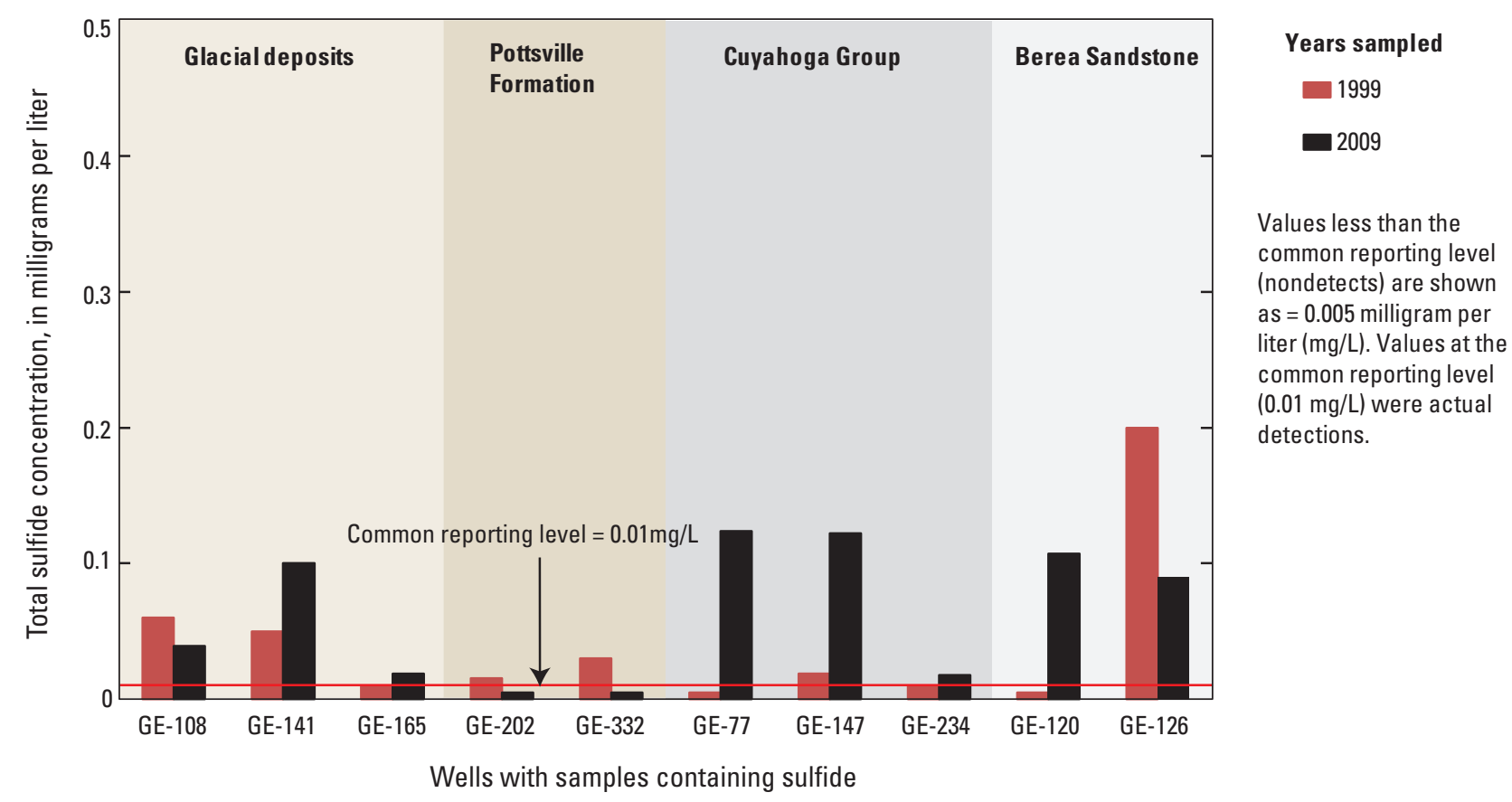

Figure 23. Sulfide concentrations in Geauga County, Ohio, 1999 and 2009, for wells producing water with a sulfide concentration greater than or equal to 0.01 milligram per liter in one or both years.

\section{Factors Affecting Contaminant Occurrence and Constituent Concentrations in Groundwater}

Eberts and others (1990) and Jagucki and Darner (2001) discussed some of the factors that influence water quality in Geauga County on the basis of groundwater analyses from a single year (1986 and 1999, respectively). To build upon this knowledge and gain new insights, the relations of water-quality constituent concentrations to factors such as well construction, well position relative to groundwater flow paths, and depth to groundwater were reexamined by using all available USGS data collected in the county from 1978 through 2009-as many as 116 samples from 65 wells (appendix table $4-1^{7}$ and appendix fig. 4-1). Additionally,

\footnotetext{
${ }^{7}$ Exceptions - The following constituents in appendix table 4-1 were not used in the correlation tests: water temperature and (because of very infrequent detections) phosphorus, E. coli, fecal coliform, fecal streptococcus, and dissolved methane.
}

the relations of constituent concentrations to upgradient land cover were evaluated by using data from the 16 domestic wells sampled in 2009 (appendix table 3-1). The strength of the associations between constituent concentrations and explanatory factors was evaluated by using the Spearman's rho correlation coefficient and graphing techniques. Factors found to be related to elevated constituent concentrations in groundwater are described in the following sections. These results may aid planning officials and homeowners in determining where various manmade and naturally occuring groundwater contaminants may be expected. 


\section{Groundwater Quality in Geauga County, Ohio-Status, 2009, and Changes During 1978-2009}

\section{Human Activities at Land Surface}

Greater concentrations of a constituent in groundwater near the land surface than at depth may indicate a near-landsurface source. The correlation between well depth (either depth to top of open interval or depth of well bottom) and the properties and constituents listed in appendix table 4-1 were assessed for all samples collected by USGS, 1978-2009. Concentrations of four constituents - chloride, total coliform bacteria, nitrate, and sulfate - and the chloride:bromide ratio decreased significantly with depth (fig. 24). These constituents, and others that are manmade or thought to be affected by human activities at land surface, are discussed below.

\section{Sources of Salinity}

Septic-system leachate is a potential source for the four constituents that had higher concentrations in groundwater near land surface than at depth (fig. 24). These constituents also have other sources (table 10). Of these four constituents, chloride is the most stable in groundwater, meaning that it does not tend to transform, dissipate, or interact with aquifer materials. Thus, chloride was considered, for the purposes of this report, to be the most reliable indicator of human influence on groundwater quality near land surface. Most samples with chloride concentrations greater than $12 \mathrm{mg} / \mathrm{L}$ - the approximate upper limit of concentrations in water from unaffected, or "background," wells in Ohio and the Midwest, as determined by Jones and Sroka (1997) and Panno and others (2005) - are from areas with shallow groundwater (less than about $50 \mathrm{ft}$ below land surface) (fig. 25). The highest concentrations (greater than $130 \mathrm{mg} / \mathrm{L}$ ) are in areas with depth to water of less than $30 \mathrm{ft}$ below land surface. To distinguish which chloride sources might be influencing shallow groundwater in Geauga County, various lines of evidence were investigated (table 11). Brines (either from spills of water produced during oil and gas drilling or from spraying of drilling brines on roads to reduce dust) were eliminated as a significant source of chloride to shallow groundwater, because chloride:bromide ratios in shallow waters that have elevated chloride concentrations (greater than $12 \mathrm{mg} / \mathrm{L}$ ) were usually greater than the ratio of 95 that is characteristic of local drilling brine (Eberts and others, 1990). Rather, chloride:bromide ratios in shallow groundwater samples with chloride concentrations exceeding background levels were generally greater than 400 (fig. 25), which is a range that Panno and others (2006) associated with Midwestern groundwater affected by septic effluent or road salt. Differentiating between the effects of septic leachate and road salt, however, is difficult. The lines of evidence examined in table 11 indicate that both septic leachate and road salt may contribute chloride to shallow groundwater in Geauga County. The correlation of chloride concentration to distance from road for 31 wells sampled in 1999 (Jagucki and Darner, 2001) — with greater concentrations found in wells nearer a road - suggests that road salt is the dominant source. Wells GE-23 and GE-341 (fig. 25) both are within $50 \mathrm{ft}$ of a road and have water levels that are less than $20 \mathrm{ft}$ below land surface. Additionally, well GE-69 (fig. 25) is within a few hundred feet of a storage area for road salt (Eberts and others, 1990, p. 57) and has a water level that is less than $30 \mathrm{ft}$ below land surface.

More densely populated areas of Geauga County likely have a greater number of septic systems (except for sewered areas) and a greater amount of road salt applied (associated with a denser road network) than areas of lower population density. Whereas chloride concentration was not significantly correlated to population density for the 16 domestic well samples from 2009, chloride concentrations did increase as percent developed plus agricultural land cover increased $($ rho $=0.56$, p-value $=0.0235)$.

Septic leachate (or possibly the spreading of biosolids) is a likely source of salinity to well GE-141 (table 11; fig. 25). The chloride:bromide ratio increased in samples from GE-141 from 420 to 1,340 between 1986 and 2009, indicating ongoing inputs of salinity not originating from brine. Specific conductance and sodium concentrations also increased between 1986 and 2009 in samples from this well (appendix table 4-1). Well GE-141 is more likely than many of the other wells to be vulnerable to contamination sources near land surface because of its shallow total depth (53 ft below land surface) and the shallow water table (only $8.14 \mathrm{ft}$ below land surface in 2009) at this location. Samples from well GE-141 had an increase in total coliform concentration from $1999(19$ colonies $/ 100 \mathrm{~mL})$ to 2009 ( 49 colonies $/ 100 \mathrm{~mL}$ ) and a fecal coliform detection in 2009, which strengthens the evidence that a fecal source has affected groundwater near this well. GE-141 is the only one of the 16 domestic wells sampled in 2009 to have permitted biosolids spreading within $500 \mathrm{~m}$ upgradient from the well. Yet, it is unclear whether the 9.9-acre field, which is authorized for land application of biosolids from the McFarland Creek Wastewater Treatment Plant (WWTP), has ever actually been used for biosolids spreading. Jerry Morgan of the Geauga County Department of Water Resources reports that during his tenure (2006 to present) the McFarland Creek WWTP has not applied biosolids to this (or any) field but has instead sent them to a permitted landfill (oral commun., Feb. 11, 2014). On the basis of fecal coliform survival rates in Florida groundwater (John and others, 2004), it seems unlikely that bacteria originating from biosolids spreading prior to 2006 would survive in groundwater through 2009. John and others (2004) showed a 99 percent die-off of fecal coliforms over a period of 2-6 weeks. 

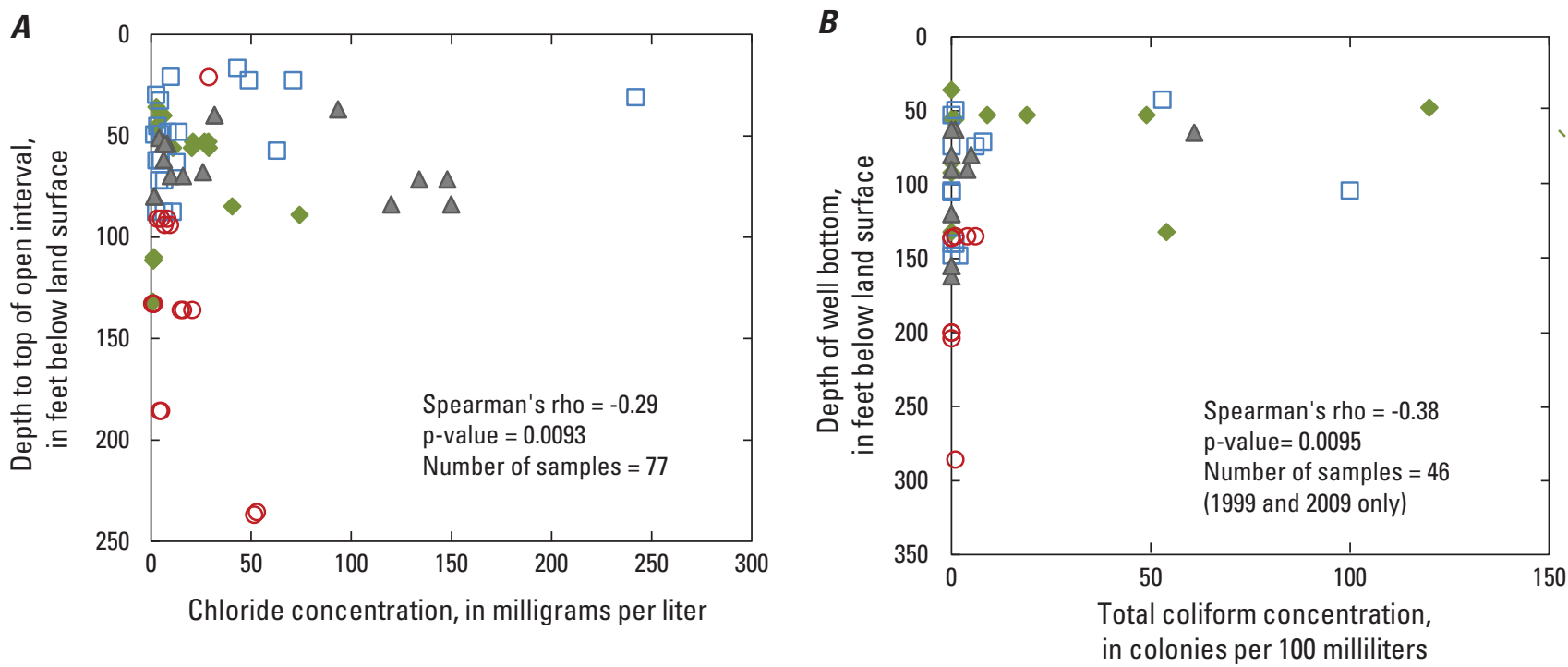

EXPLANATION

$\begin{array}{ll}\diamond \text { Glacial deposits } & \triangle \text { Cuyahoga Group } \\ \square \text { Pottsville Formation } & \circ \text { Berea Sandstone }\end{array}$

C

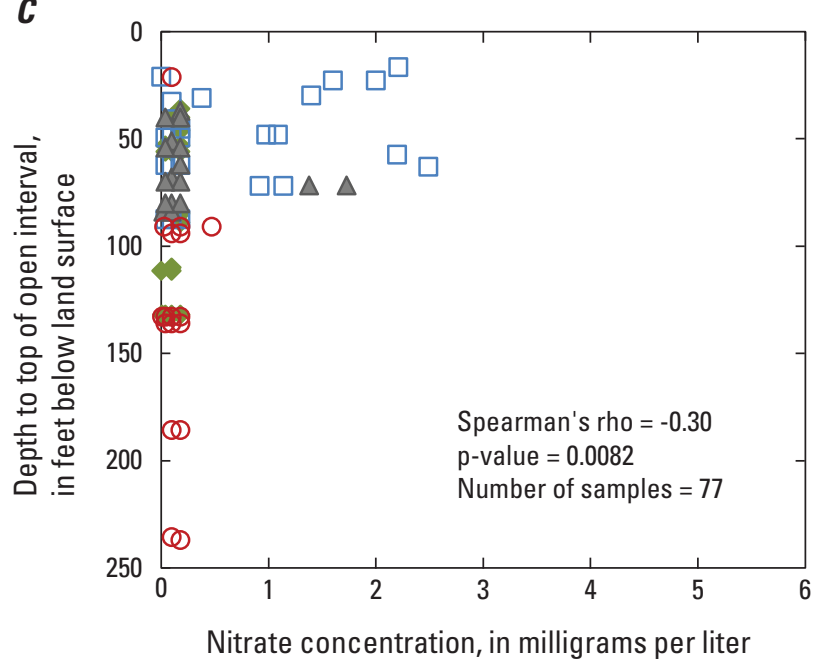

D

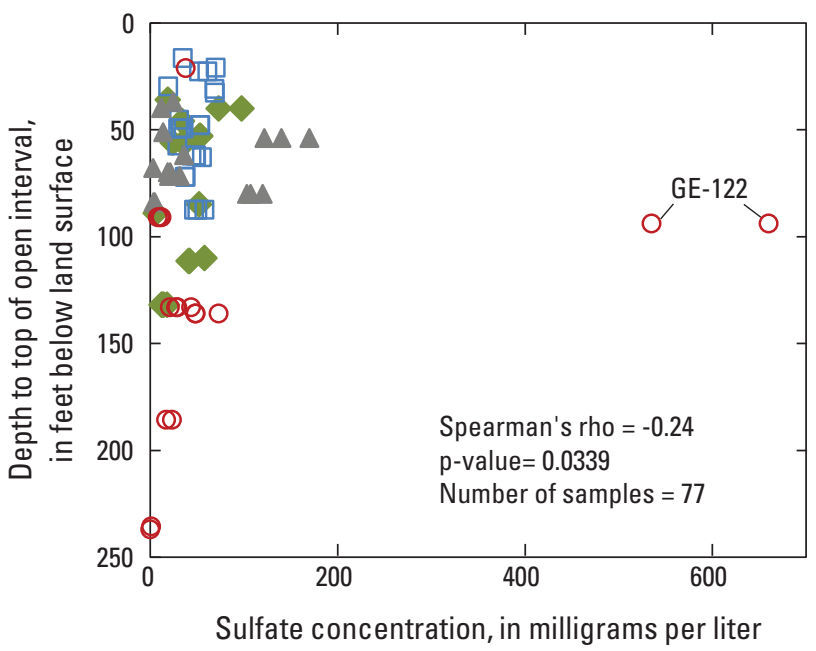

Figure 24. Relation of selected constituent concentrations to well depth for samples collected by the U.S. Geological Survey, Geauga County, Ohio, 1978-2009. A, Chloride. B, Total coliform bacteria. C, Nitrate. D, Sulfate. (Open interval is the uncased part of the well, through which groundwater enters the well.) 


\section{Groundwater Quality in Geauga County, Ohio-Status, 2009, and Changes During 1978-2009}

Table 10. Possible sources near land surface of selected constituents in groundwater.

\begin{tabular}{lcc}
\hline \multicolumn{1}{c}{ Constituent } & \multicolumn{1}{c}{ Possible sources near land surface } & Stability in groundwater \\
\hline Chloride & $\begin{array}{c}\text { Septic leachate, road salt, spills of brines produced during oil and gas } \\
\text { drilling or spraying of drilling brines on roads for dust control }\end{array}$ & Stable. \\
$\begin{array}{l}\text { Total coliform } \\
\text { bacteria }\end{array}$ & $\begin{array}{c}\text { Septic leachate, livestock manure, application of biosolids or septage to } \\
\text { agricultural fields, soils }\end{array}$ & $\begin{array}{c}\text { Dies off under typical } \\
\text { groundwater conditions. }\end{array}$ \\
Nitrate & $\begin{array}{c}\text { Septic leachate, fertilizer, livestock manure, application of biosolids or } \\
\text { septage to agricultural fields, nitrogen-fixing plants and decomposing plants }\end{array}$ & $\begin{array}{c}\text { Transforms to ammonia } \\
\text { and (or) nitrogen gas in } \\
\text { a reducing geochemical } \\
\text { environment. }\end{array}$ \\
& Septic leachate, combustion of fossil fuels, fertilizer, livestock manure, \\
field application of biosolids or septage & $\begin{array}{c}\text { Transforms to sulfide in a } \\
\text { reducing geochemical } \\
\text { environment. }\end{array}$ \\
\hline
\end{tabular}

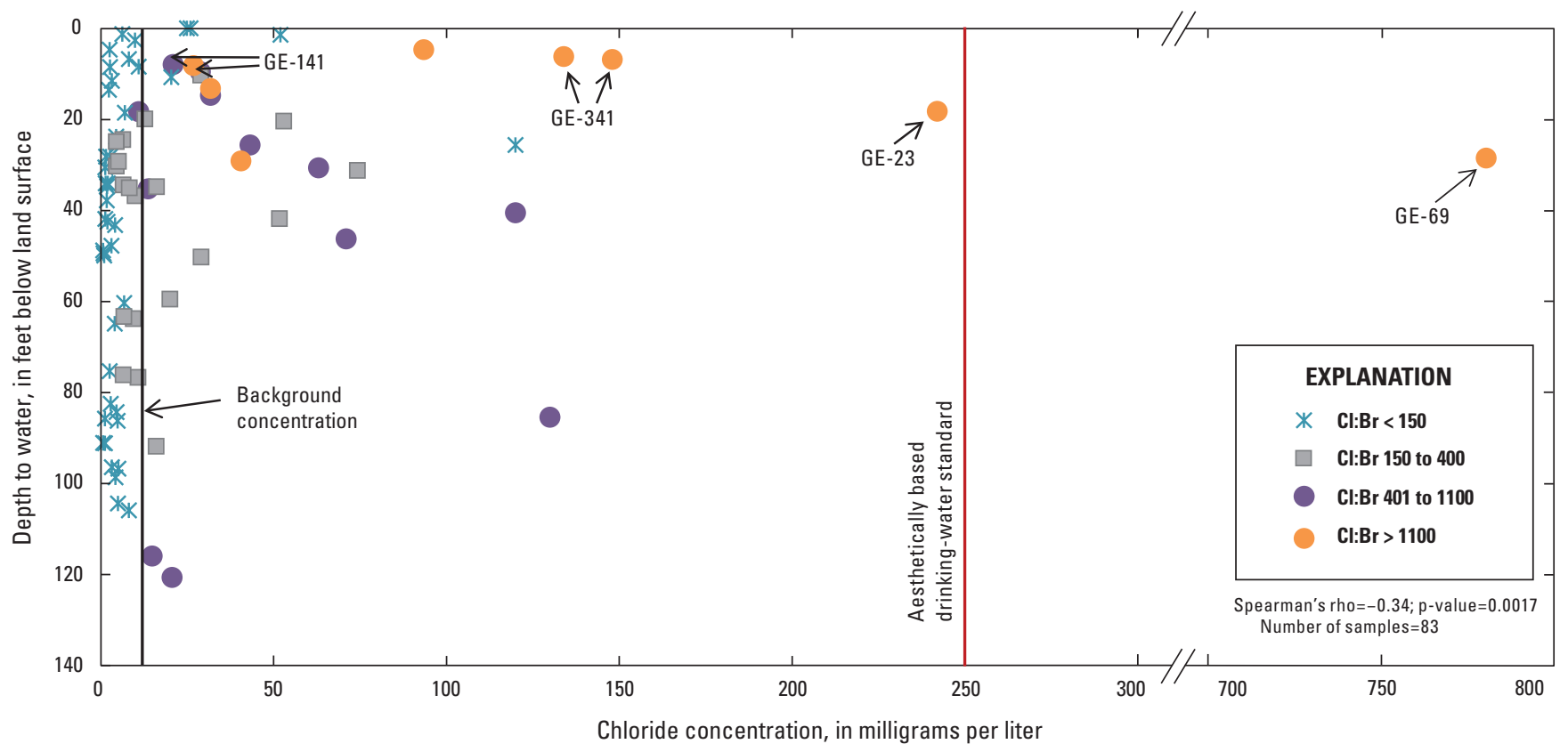

Figure 25. Relation of chloride concentration to depth to water for samples collected by the U.S. Geological Survey in Geauga County, Ohio, 1986-2009. (Cl:Br, ratio of chloride to bromide.) 
Table 11. Lines of evidence investigated to distinguish between sources of salinity in groundwater of Geauga County, Ohio.

[>, greater than; $\mathrm{Cl}: \mathrm{Br}$, ratio of chloride to bromide; $\checkmark$, the evidence presented supports this source; $\mathbf{X}$, the evidence presented rules out this source; $\mathrm{x}$, the absence of the presented correlation or detection does not rule this source out, but its presence would have confirmed this source; - , not applicable to this source.]

\begin{tabular}{|c|c|c|c|c|}
\hline \multirow[b]{2}{*}{ Applicability } & \multirow[b]{2}{*}{ Evidence investigated } & \multicolumn{3}{|c|}{ Salinity source } \\
\hline & & $\begin{array}{c}\text { Road } \\
\text { salt }\end{array}$ & $\begin{array}{c}\text { Septic } \\
\text { leachate }^{1}\end{array}$ & Brine \\
\hline \multirow{9}{*}{ 兑 } & (1) Chloride concentration decreases with depth (indicates surface source). & $\checkmark$ & $\checkmark$ & $\checkmark$ \\
\hline & $\begin{array}{l}\text { (2) Chloride concentration is }>12 \mathrm{mg} / \mathrm{L} \text { (background concentration) in shallow } \\
\text { groundwater. }\end{array}$ & $\checkmark$ & $\checkmark$ & $\checkmark$ \\
\hline & $\begin{array}{l}\text { (3) } \mathrm{Cl}: \mathrm{Br} \text { is }>400 \text { in most groundwater samples with chloride } \\
\text { concentration }>\text { background. }\end{array}$ & $\checkmark$ & $\checkmark$ & $\mathbf{X}$ \\
\hline & $\begin{array}{l}\text { (4) Chloride concentrations and } \mathrm{Cl}: \mathrm{Br} \text { are positively correlated to concentrations } \\
\text { of nitrate (which can have a septic source). }\end{array}$ & - & $\checkmark$ & - \\
\hline & $\begin{array}{l}\text { (5) Total coliform bacteria concentrations (which can have a septic source) are } \\
\text { not correlated to concentrations of chloride or nitrate, or to } \mathrm{Cl}: \mathrm{Br} \text {. }\end{array}$ & - & $\mathrm{X}$ & - \\
\hline & $\begin{array}{l}\text { (6) Concentrations of other indicators of septic leachate (boron [present in some } \\
\text { laundry detergents], potassium, sulfate, organic carbon) are not significantly } \\
\text { correlated to concentrations of chloride, total coliform, or to each other. }\end{array}$ & - & $\mathrm{x}$ & - \\
\hline & $\begin{array}{l}\text { (7) E. coli bacteria, which only have a fecal source, were not detected in any } \\
\text { wells. }\end{array}$ & - & $\mathrm{x}$ & - \\
\hline & $\begin{array}{l}\text { (8) Chloride concentration was positively correlated to distance from road for } 31 \\
\text { wells sampled in } 1999 \text { (Jagucki and Darner, 2001). }\end{array}$ & $\checkmark$ & - & $\checkmark$ \\
\hline & $\begin{array}{l}\text { (9) Chloride concentration is positively correlated to percent developed plus } \\
\text { agricultural land cover. }\end{array}$ & $\checkmark$ & $\checkmark$ & - \\
\hline \multirow{2}{*}{ 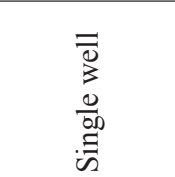 } & $\begin{array}{l}\text { (10) Concentration of total coliform bacteria increased in well GE-141 from } 1999 \\
\text { to } 2009 .\end{array}$ & - & $\checkmark$ & - \\
\hline & $\begin{array}{l}\text { (11) Fecal coliform bacteria were detected in well GE-141 in } 2009 \text { (strengthens } \\
\text { evidence that bacteria in well have a fecal source). }\end{array}$ & - & $\checkmark$ & - \\
\hline
\end{tabular}

\footnotetext{
${ }^{1}$ Evidence indicating that septic leachate is influencing shallow groundwater could also be used to suggest that biosolids or septage are affecting water quality. However, septic leachate was determined to be a more likely source to wells sampled in the county, because only one well (GE-141) had a permitted biosolids-spreading field within 500 meters upgradient of the well, and biosolids had not been spread on this field since prior to 2006 (if ever).
} 


\section{Groundwater Quality in Geauga County, Ohio-Status, 2009, and Changes During 1978-2009}

\section{Other Factors That Can Influence Concentrations of Total Coliform Bacteria, Nitrate, and Sulfate}

Bacteria.-Concentrations of total coliform bacteria in water from wells in Geauga County were determined in a total of 46 samples collected by the USGS in 1999 and 2009 (appendix table 4-1). With a couple of exceptions, the most elevated concentrations of total coliforms were found in wells with bottom depths of $70 \mathrm{ft}$ or less below land surface (fig. 24B). No concentrations exceeding the health-based standard of 4 colonies per $100 \mathrm{~mL}$ occurred in wells with bottom depths greater than $140 \mathrm{ft}$ below land surface. Total coliforms were also negatively correlated to depth to top of open interval $(\mathrm{rho}=-0.35$, $\mathrm{p}$-value $=0.018)$, meaning that greater concentrations occurred in wells with shallow cased intervals. Total coliform concentrations in water samples from the 16 wells sampled in 2009 were not correlated to any land use factors or population density. In fact, the only factor other than well construction that was significantly correlated to total coliform concentration was turbidity $(\mathrm{rho}=0.66$, $\mathrm{p}$-value $=$ 0.0056) (fig. 26). This result is expected, because bacteria tend to cling to particulates rather that float freely in water. During the 2009 sampling round, four of the six samples with turbidity above 5 nephelometric turbidity units (NTU) contained detectable total coliform bacteria (fig. 26); 5 NTU is the threshold for visible turbidity (Strausberg, 1983). Turbidity values greater than about 25 NTU might indicate failure of the well casing or improper well construction (U.S. Geological Survey, 1997-present, chapter 4.2.2.A, p. 91) that allows surface runoff (and any associated total coliform bacteria) to directly enter the well. Elevated turbidity may also be caused by precipitating sulfide minerals, which would appear as finely disseminated black particulates in groundwater. (Samples from a geochemical environment conducive to the precipitation of sulfide minerals are indicated by red circles in fig. 26).
Nitrate.-Nitrate concentrations greater than $1 \mathrm{mg} / \mathrm{L}$ occurred primarily in domestic wells tapping the Pottsville Formation with casing that extends less than $75 \mathrm{ft}$ below land surface (fig. 24C). In addition, the highest nitrate concentrations in water from domestic wells were found in areas with the greatest percentage of agricultural land use (fig. 27A) or developed land use (fig. 27B) (although the association was not statistically significant). Developed and agricultural land uses are more likely to contain nitrogen sources such as septic systems, fertilizer, and manure than forested, grassland, and wetland land uses. The type of subsurface geochemical environment tapped by the wells is perhaps the dominant control on nitrate concentrations in groundwater (fig. 27C). Many wells in the county tap "strongly reducing" subsurface environments that are not favorable to the persistence of nitrate, regardless of the type of upgradient land use. This will be discussed in more detail in the Naturally Occurring Geochemical Processes in the Subsurface section of this report.

Sulfate.-A single Berea well in Bainbridge Township (GE-122, appendix fig. 4-1) produced water with sulfate concentrations greater than $500 \mathrm{mg} / \mathrm{L}$ during two consecutive sampling rounds (fig. 24D). Although greater concentrations of sulfate occur in the southwestern part of the county, based on poor to fair but significant correlations of sulfate to latitude (rho $=-0.28, \mathrm{p}$-value $=0.0002)$ and longitude (rho $=0.19, \mathrm{p}$-value $=0.0371$ ) for 116 samples collected by the USGS during 1978-2009, concentrations above $500 \mathrm{mg} / \mathrm{L}$ are atypical. Concentrations of sulfate tend to decrease with depth below land surface (fig. 24D). This does not appear to be caused by changes in geochemical conditions with depth, because many of the samples throughout the entire depth interval shown in fig. 24D - even samples with elevated sulfate concentrations (greater than $70 \mathrm{mg} / \mathrm{L}$ ) - are from an environment conducive to the transformation of sulfate to sulfide.

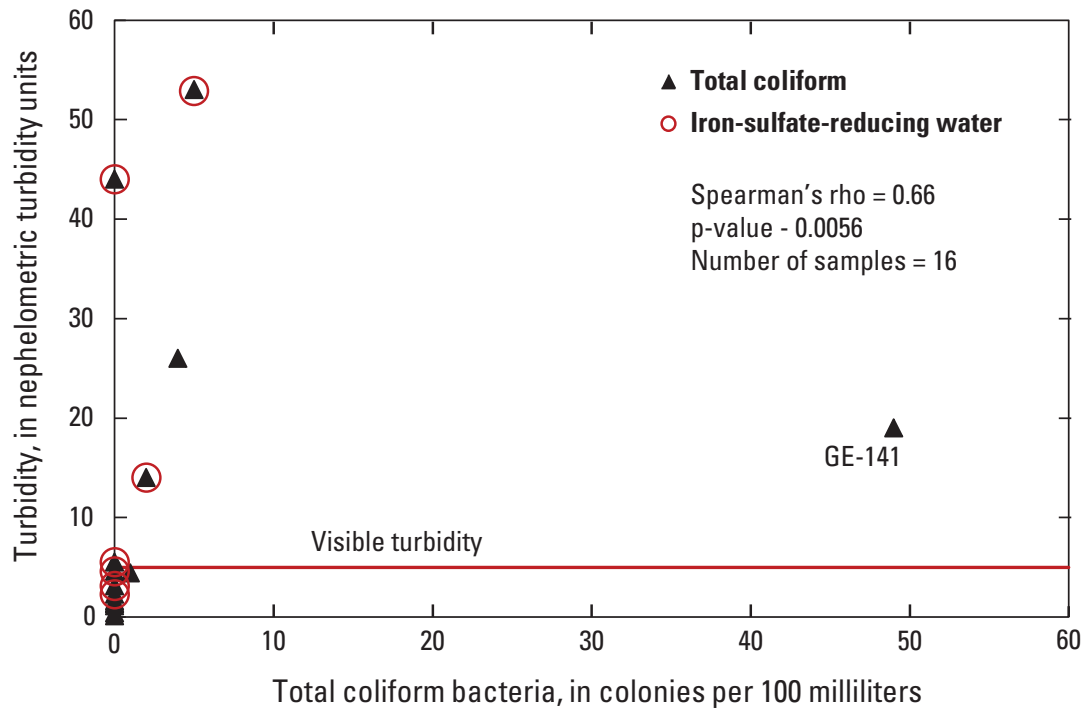

Figure 26. Concentration of total coliform bacteria as a function of turbidity for samples collected by the U.S. Geological Survey from domestic wells, Geauga County, Ohio, 2009. 

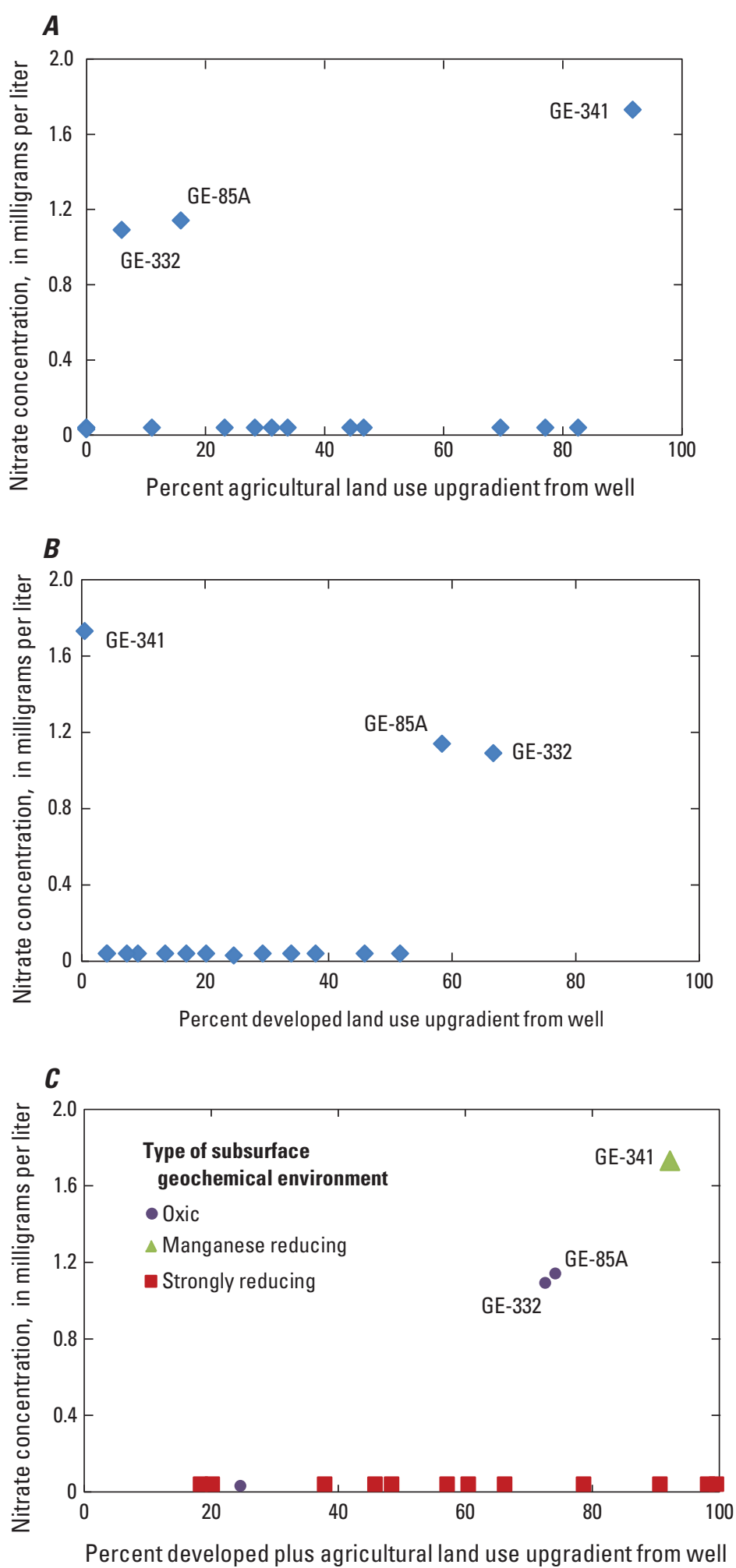

Figure 27. Relation of nitrate concentration to environmental characteristics for samples collected by the U.S. Geological Survey in Geauga County, Ohio, 2009. A, Percent agricultural land use. $B$, Percent developed upgradient land use. $C$, Subsurface geochemical environment.
Sulfate concentrations in the 16 domestic wells sampled by USGS in 2009 were not significantly correlated with population or developed land use. Absence of correlation of sulfate to constituents indicative of septic leachate (table 11, item 6) or percent agricultural land use suggests that these sources (along with biosolidsand septage-spreading on agricultural fields) may not be important sources of sulfate to groundwater in Geauga County. A more likely source of sulfate is combustion of fossil fuels. Combustion of fossil fuels releases sulfur dioxide to the atmosphere that combines with water to produce sulfate ions and acidity in rainfall, "especially in air masses that have encountered metropolitan areas" (Edwards and others, 2011). Northeastern Ohio is an area of acidic rainfall (U.S. Geological Survey, 2014) and a high rate of atmospheric sulfate deposition relative to much of the United States (Burns and others, 2011). Atmospheric deposition may account for the trend of increasing sulfate concentration and decreasing $\mathrm{pH}$ during 1978-2009 in groundwater samples from the Cuyahoga Group (table 9).

\section{Activities Affecting Pesticide and VOC Concentrations}

The paucity of pesticide and VOC detections in Geauga County means that either (a) human activities have generally not added these constituents to the groundwater, (b) drain tiles in agricultural areas have diverted infiltrating pesticides from groundwater to streams, or (c) pesticides and VOCs reaching the groundwater system have not persisted. As in the national study (Gilliom and others, 2006) that found pesticides in groundwater primarily in agricultural and urban areas, the only pesticides detected in Geauga County were in water from domestic well GE-341, which has an upgradient land use of approximately 92 percent agricultural - the highest of any well sampled (fig. $27 A$ and appendix table 3-1). Depth to groundwater in well GE-341 is very shallow (less than $10 \mathrm{ft}$ below land surface), adding to its vulnerability.

Results of VOC sampling in Geauga County were consistent with a national study of VOC occurrence in groundwater (Zogorski and others, 2006) that found urban land use to be one of the factors most commonly associated with VOCs in groundwater and also found more frequent VOC detections in samples from public-supply wells than from domestic wells. VOC detections were tabulated for samples from 31 domestic wells and 7 public-supply well fields in Geauga County (appendix table 4-3). Only one VOC - total xylenes - that was not a chlorination byproduct was detected at a very low concentration in 1 out of 31 samples collected at the Lake Lucerne public-supply well field. This well field has the most densely populated and developed upgradient land use of any well analyzed for the current study (fig. 28). 


\section{Groundwater Quality in Geauga County, Ohio-Status, 2009, and Changes During 1978-2009}

\section{Activities Affecting Bromide and Organic Carbon Concentrations}

Processes affecting the decrease in concentration of bromide in groundwater from 1986 to 2009 (table 9) are not readily apparent. Like chloride, bromide concentrations are greatest in wells with depth to groundwater less than about $50 \mathrm{ft}$ below land surface (fig. 29), suggesting a surface source for much of the bromide. Because bromide is associated with sources of salinity (and particularly with brines produced during oil and gas drilling), it is perplexing that bromide has decreased during a period in which chloride concentrations were stable (table 9). One possibility for this relation is that a decrease in the amount of oil-field brine at land surface (caused by either [a] the shift from storing brine in earthenbermed reserve pits to disposing of it in Class II injection wells in 1986, or [b] an undocumented reduction in the amount of brine spread on roads) has caused a decrease in brine infiltration to shallow groundwater that was concurrent with the increase in road-salt use documented in figure 10. This would have resulted in unchanging or increasing chloride concentrations while chloride:bromide ratios increased and bromide concentrations decreased. This process would be consistent with changes in groundwater quality from 1986 to 2009 (tables 8 and 9) and with the observation that well GE-165, site of both the highest bromide concentration and the greatest decrease in concentration from 1999 to 2009 (from $0.21 \mathrm{mg} / \mathrm{L}$ to $0.11 \mathrm{mg} / \mathrm{L}$, fig. 30), is in Auburn
Township (fig. 5) where brines are spread on roads. However, widespread inputs of oil-field brines to wells in the county have not been identified by use of chloride:bromide ratios (table 11 and fig. 25).

Another possible explanation for the decrease in bromide concentrations in groundwater over time is the phaseout of leaded gasoline, beginning in the mid-1970s, which contained the additive ethylene dibromide (U.S. Environmental Protection Agency, 2013). Ethylene dibromide was also used in the past as a fumigant in vegetable and grain crops and on turf. The USEPA banned its use as a soil and grain fumigant in 1984. Ethylene dibromide was analyzed for in samples from the ASM International public-supply well on nine different dates during 1995-2009, but it was never detected (appendix table 4-3); data predating the leaded gasoline phaseout were not examined for this report and so cannot be used to test this theory. However, distance of well from road is not uniformly related to the magnitude of bromide concentration decrease that was observed from 1999 to 2009 in domestic wells (fig. 30).

The reason for the decline in dissolved organic carbon concentrations during 1978-2009 (tables 8B and 9) is unknown. Declines were seen in all aquifers except the glacial deposits. The relatively short timeframe for the decline (decades) suggests it may be caused by some change in human activities rather than by a geologic process.

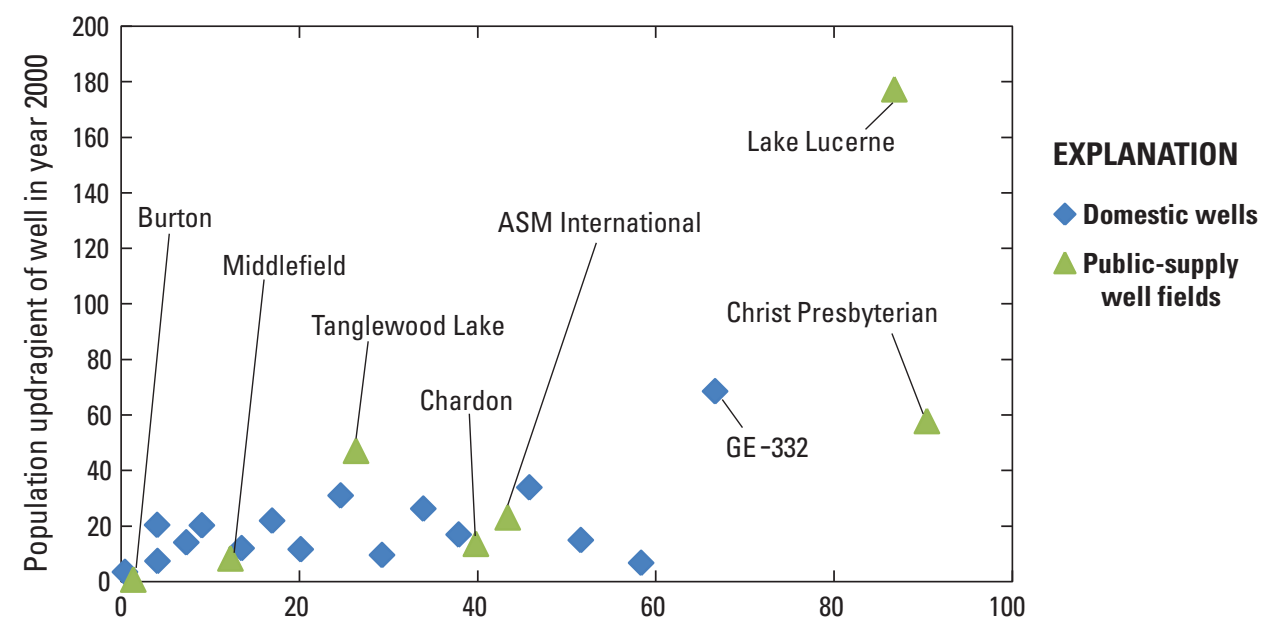

Percent developed land use upgradient of well in 2001

Figure 28. Population and percent developed land use upgradient of public-supply well fields considered in this report and domestic wells sampled in 2009, Geauga County, Ohio. (Public-supply well data source is listed in table 4, domestic wells are listed in table 3, and land-use and population data are in appendix 3.) 


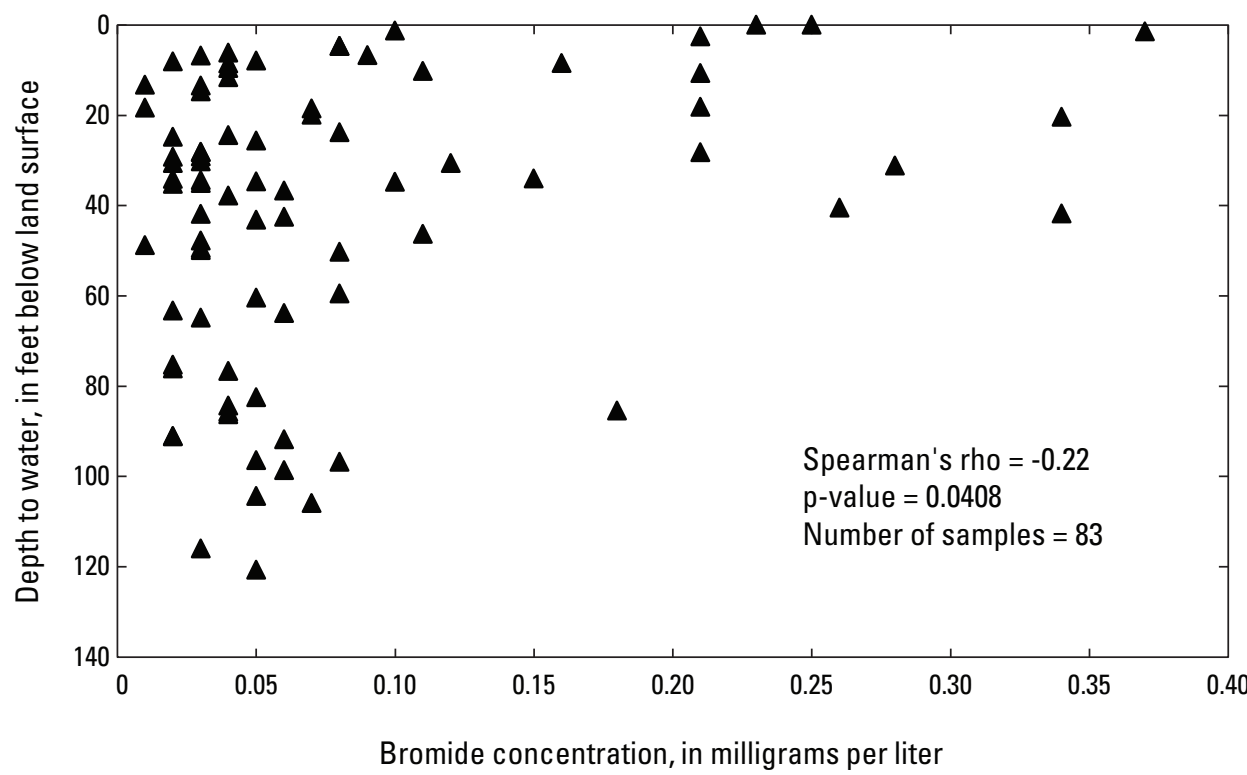

Figure 29. Concentration of bromide as a function of depth to water in wells sampled by the U.S. Geological Survey, Geauga County, Ohio, 1986-2009.

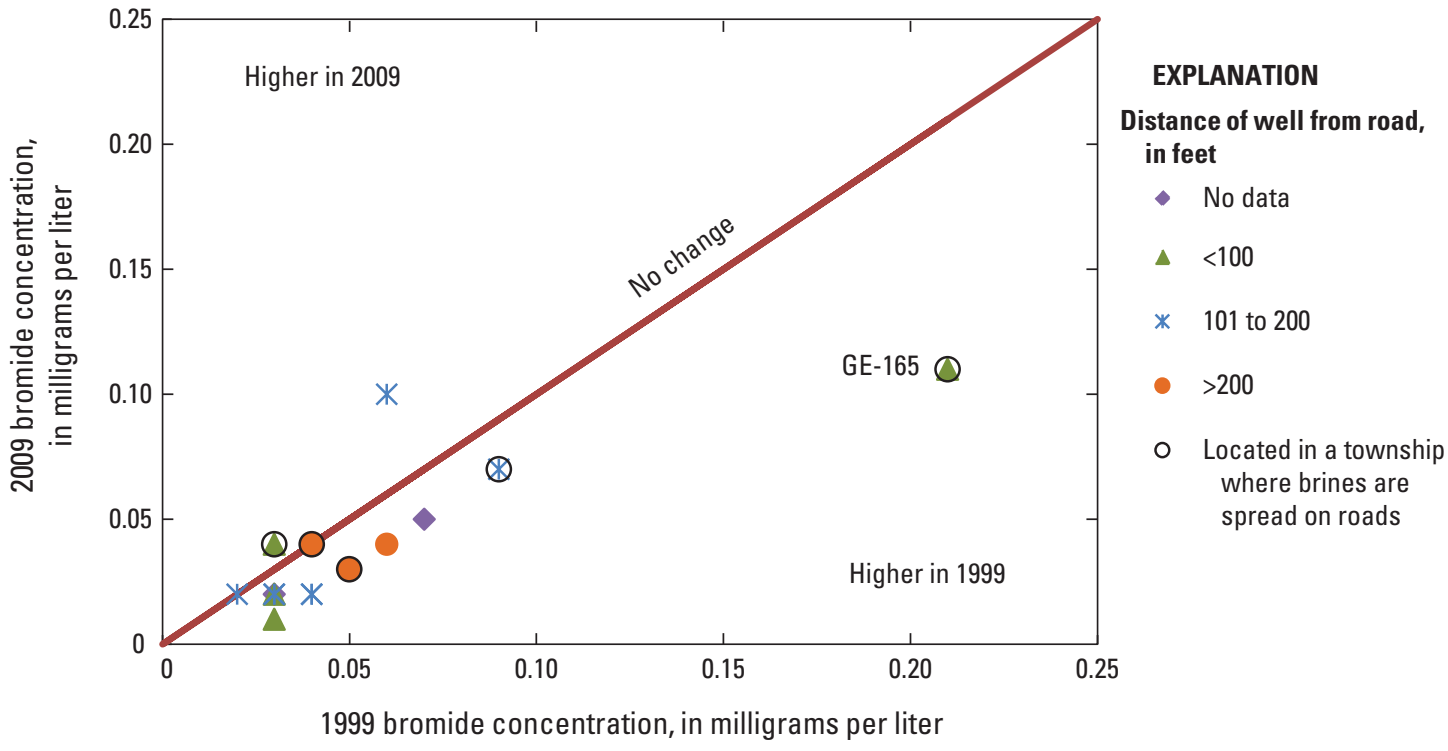

Figure 30. Changes from 1999 to 2009 in bromide concentrations as a function of distance of well from road for wells sampled by the U.S. Geological Survey, Geauga County, Ohio.

\section{Naturally Occurring Geochemical Processes in the Subsurface}

Naturally occurring processes occurring in the subsurface that influence the quality of groundwater in Geauga County include evolution of groundwater along a flow path, ion-exchange reactions with aquifer sediments, and oxidationreduction (redox) reactions. These processes can cause some of the observed differences in water chemistry between aquifers described by Jagucki and Darner (2001). Jagucki and Darner found that, of the four aquifers, the majority of statistically significant differences in constituent concentrations occurred between the Pottsville Formation and the Berea Sandstone. 


\section{Groundwater Quality in Geauga County, Ohio-Status, 2009, and Changes During 1978-2009}

\section{Evolution of Groundwater Along a Flow Path}

Many of the observed differences in chemistry between aquifers are related to the amount of time that groundwater in the aquifer has been in contact with subsurface rocks and sediments (also known as "groundwater residence time"). In general, the longer the distance that the groundwater has traveled from the water table (depicted by length of flow lines on figures 1 and 2), the longer the residence time of groundwater in the aquifer and the greater the amount of minerals that will have been dissolved from aquifer rocks into groundwater. In the hilly topography of Geauga County, groundwater flows along short, isolated flow paths that originate at the hilltops (which are capped by the Pottsville Formation and a thin cover of glacial deposits) and travel downward and laterally (figs. $1 \mathrm{~A}$ and 2). Water in the Pottsville Formation entered the aquifer relatively recently and thus has had limited contact time with aquifer materials. As a result, samples from the Pottsville Formation generally have lower concentrations of many dissolved constituents than samples from the Berea Sandstone (fig. $31 A-K$ ). Much of the groundwater that reaches the Berea Sandstone has traveled downward from the Pottsville Formation and through the Cuyahoga Group. Water in the Berea Sandstone and lower Cuyahoga Group has generally been in contact with aquifer rocks for decades or centuries, according to simulations by Eberts and others (1990) (fig. 2), dissolving and sometimes precipitating aquifer minerals.

In Geauga County, the residence time of groundwater withdrawn from a particular well relative to that withdrawn from other wells is best approximated by the elevation of the well bottom (rather than to depth of well measured as feet below land surface), because of the hilly topography and strong downward component of groundwater flow in the area. (Elevation of well bottom becomes a less reliable approximation for groundwater residence time at lower elevations once water reaches the Berea Sandstone, where flow is largely lateral, and on the eastern edge of the county, where flow in the Cuyahoga Group is predominantly lateral [fig. 2]). The relation of tritium concentration to well-bottom elevation (fig. $31 L$ ) provides evidence that groundwater age (and thus groundwater residence time) generally increases at lower elevations. Tritium, a radioactive isotope of hydrogen, is an age tracer that was analyzed for in several of the groundwater samples collected in 1999 (Jagucki and Darner, 2001) and in two additional samples from the Berea Sandstone in 2009 (appendix table 4-1). Concentrations of tritium in precipitation of northeastern Ohio, 1953-1983, were estimated by Michel (1989). Michel found that tritium concentrations in precipitation increased substantially after 1953 as a result of nuclear weapons testing. Concentrations peaked in 1963 and then declined to about 22-48 picocuries per $\operatorname{liter}^{8}(\mathrm{pCi} / \mathrm{L})$ by 2009 (R.L. Michel, U.S. Geological Survey, written commun., 2008). Jagucki and Darner (2001) adjusted Michel's precipitation data to account for radioactive decay of tritium that would have happened between the time the preciptation occurred

\footnotetext{
${ }^{8} 22-48 \mathrm{pCi} / \mathrm{L}=7-15$ tritium units (TU).
}

and 1999. This allowed them to determine when samples of groundwater collected in 1999 had originally entered, or recharged, the aquifer system based on tritium analyses. These calculations showed that "old" groundwater in northeastern Ohio that recharged prior to 1953 would have a low tritium concentration (less that $5.7 \mathrm{pCi} / \mathrm{L}^{9}$ ) in 1999; "young" water that recharged after 1953 would have a tritium concentration greater than $5.7 \mathrm{pCi} / \mathrm{L}$ in 1999 as long as there had not been substantial mixing of young and old water within the aquifer (Jagucki and Darner, 2001). A plot of all tritium data collected in Geauga County as a function of well elevation (fig. $31 L$ ) shows that, in general, samples from wells with a bottom elevation above about $1,050 \mathrm{ft}$ and completed in either the Pottsville Formation or the Cuyahoga Group contained tritium at concentrations greater than $5.7 \mathrm{pCi} / \mathrm{L}$ in 1999 and are indicative of young water. Conversely, most samples from wells with a bottom elevation lower than 1,050 ft and completed in the Berea Sandstone had low tritium concentrations in 1999 that are indicative of old water. Some wells completed in the glacial deposits and located in buried valleys at low elevations likely receive a mix of young and old water that has discharged from all bedrock units and thus contain intermediate concentrations of tritium.

Several constituents and properties had a statistically significant $(\mathrm{p}<0.05)$ and good to fair negative correlation to elevation of well bottom (meaning that concentrations increase at lower elevations). In order of decreasing correlation strength, these are ammonia, $\mathrm{pH}$, boron, sodium, fluoride, alkalinity, sulfide, specific conductance, dissolved solids, potassium, and silica (fig. 31). Silica and potassium are common in sedimentary rocks, as are lesser amounts of fluoride and boron. The concentration of dissolved solids represents the concentration of ions dissolved in groundwater; specific conductance is another measure of dissolved ion concentration. Logically, all of the listed chemical constituents would increase in concentration along a groundwater flow path as mineral dissolution increases. Because $\mathrm{pH}$ and alkalinity increase as a result of dissolution reactions, values of these properties also tend to increase with increased groundwater residence time. Ammonia and sulfide concentrations are likely related to redox reactions (see later section) that can also be a function of flow-path length.

\section{Ion-Exchange Reactions With Aquifer Sediments}

Ion exchange is a natural process in the subsurface that has a substantial effect on sodium concentrations in water produced by wells in Geauga County. Sodium concentrations of groundwater samples in the county are related primarily to the geologic formation in which the well is completed. Six of the 16 samples collected in 2009 from domestic wells had sodium concentrations that exceeded health-based benchmarks (appendix table 4-1 and table 5); these six samples were from wells completed in either the Cuyahoga Group or the underlying Berea Sandstone, both of which were deposited

\footnotetext{
${ }^{9} 5.7 \mathrm{pCi} / \mathrm{L}=1.8 \mathrm{TU}$.
} 

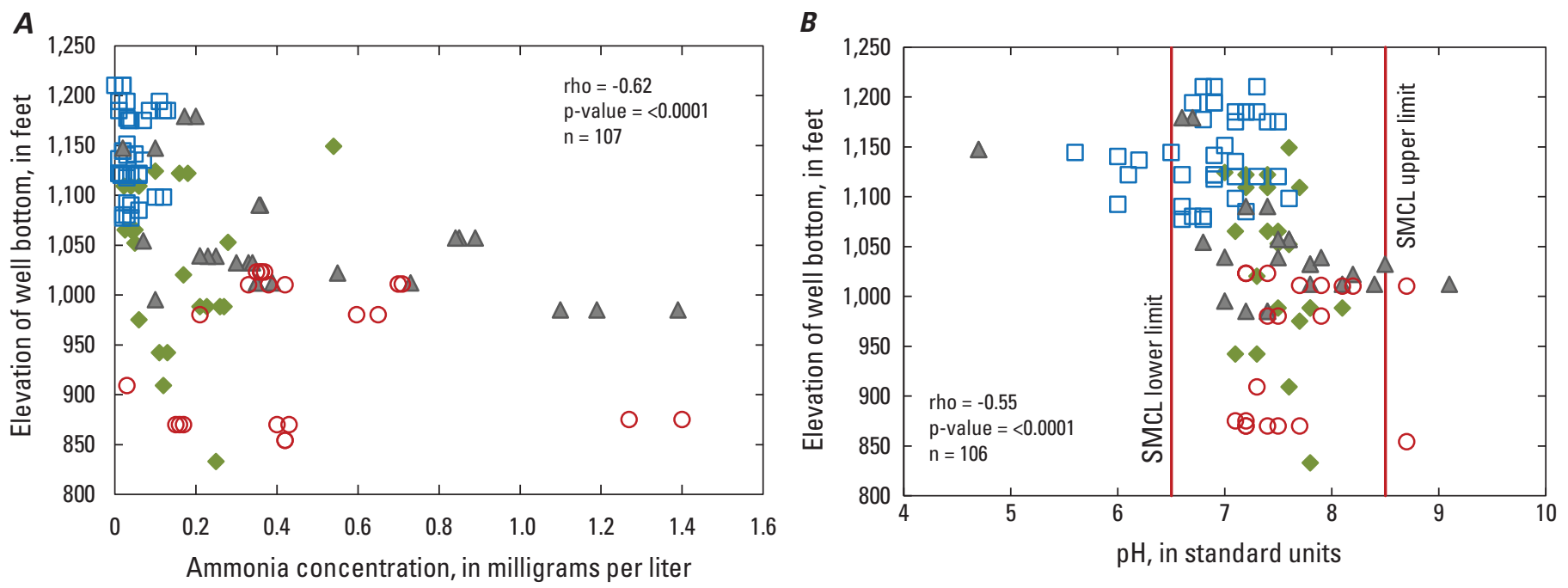

\section{EXPLANATION}

Aquifer

- Glacial deposits $\Delta$ Cuyahoga Group

$\checkmark$ Pottsville Formation $\bigcirc$ Berea Sandstone
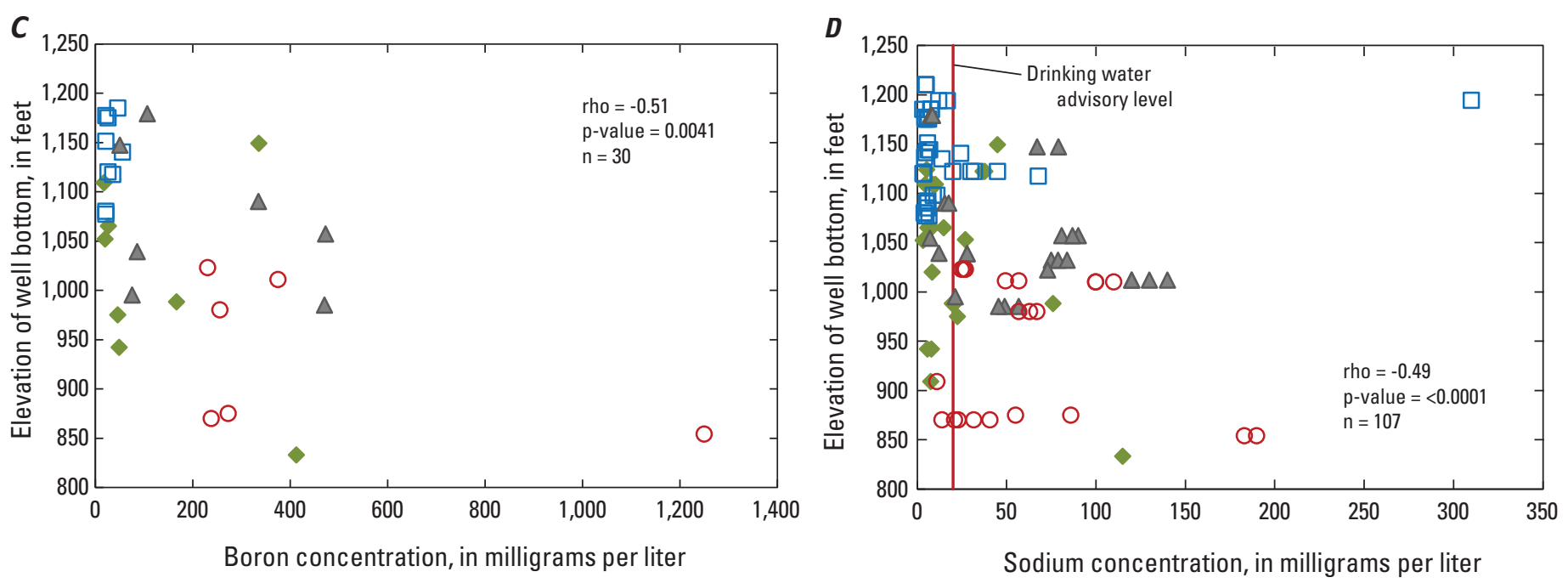

Figure 31. Relation of selected constituent concentrations to elevation of well bottom for samples collected by the U.S. Geological Survey, Geauga County, Ohio, 1978-2009. (Rho is Spearman's rho correlation coefficient; p-value is statistical significance of correlation; $\mathrm{n}$ is number of samples; SMCL is Secondary Maximum Contaminant Level.) 
E

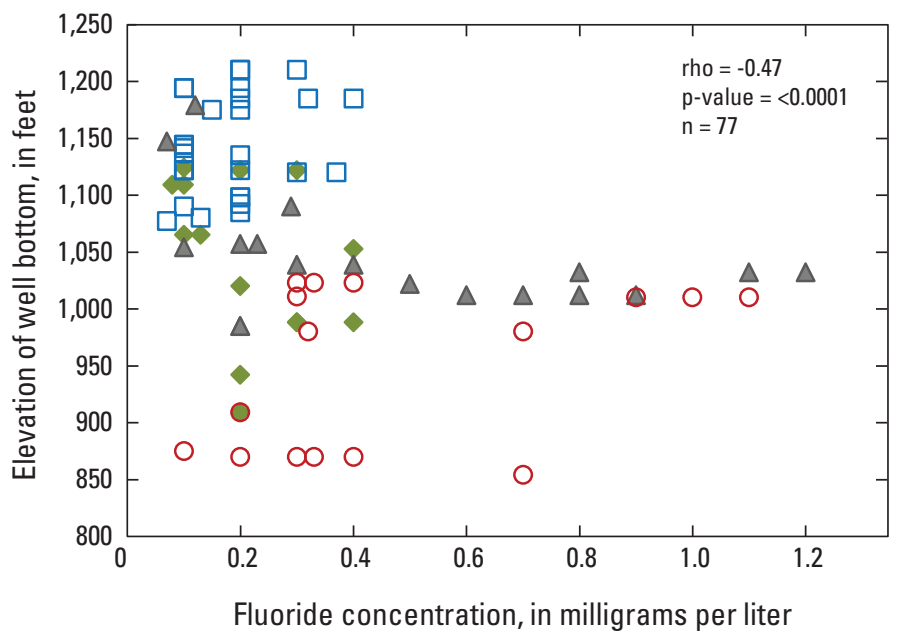

$\boldsymbol{F}$

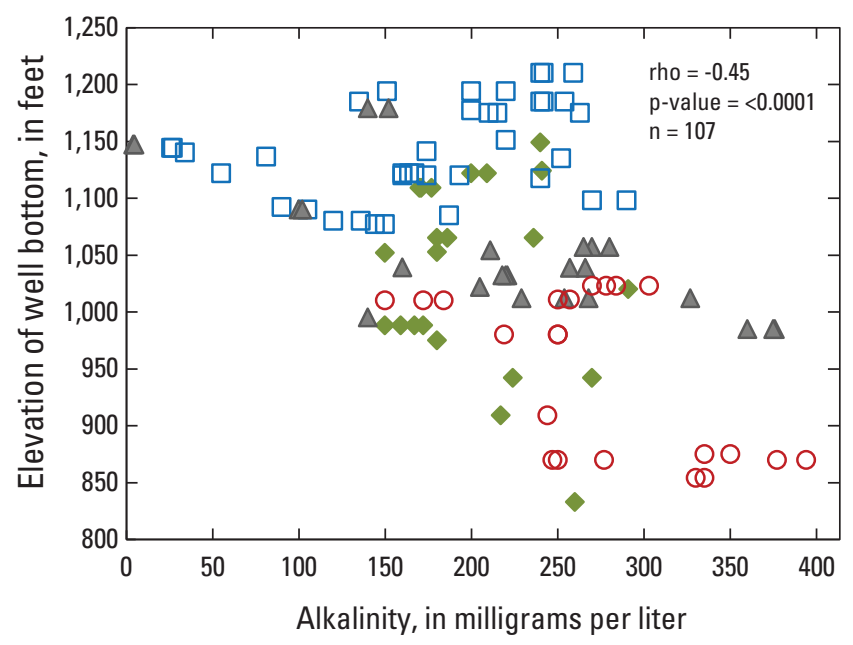

\section{EXPLANATION}

Aquifer

- Glacial deposits

$\triangle$ Cuyahoga Group

$\square$ Pottsville Formation

○ Berea Sandstone
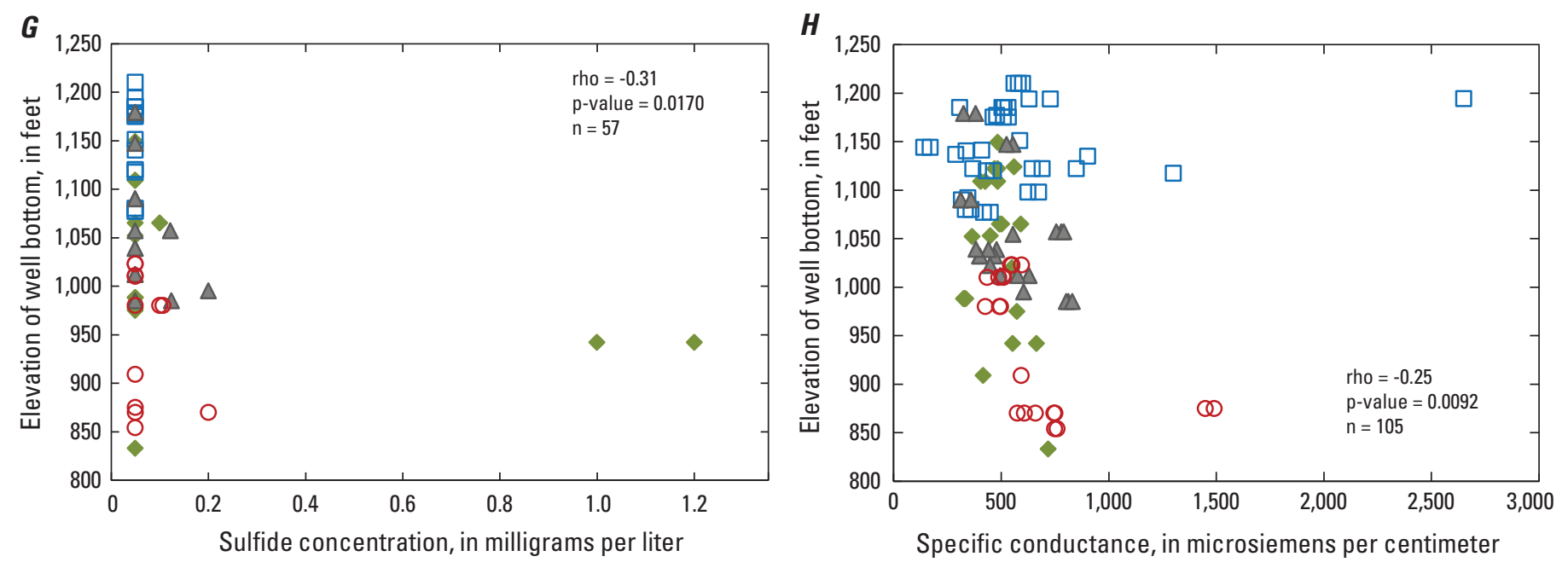

Figure 31. Relation of selected constituent concentrations to elevation of well bottom for samples collected by the U.S. Geological Survey, Geauga County, Ohio, 1978-2009. (Rho is Spearman's rho correlation coefficient; p-value is statistical significance of correlation; $\mathrm{n}$ is number of samples; $\mathrm{SMCL}$ is Secondary Maximum Contaminant Level.)—Continued 
I

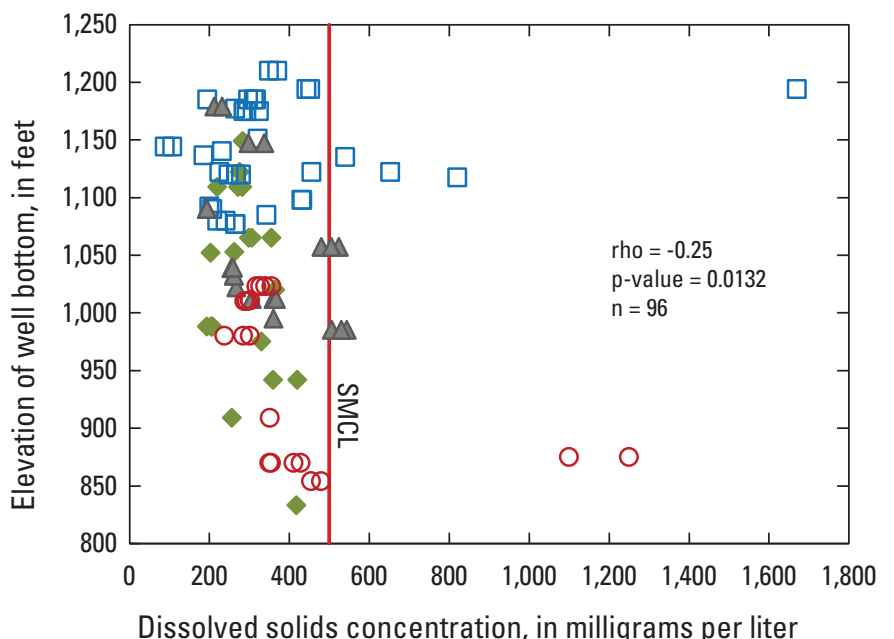

$J$

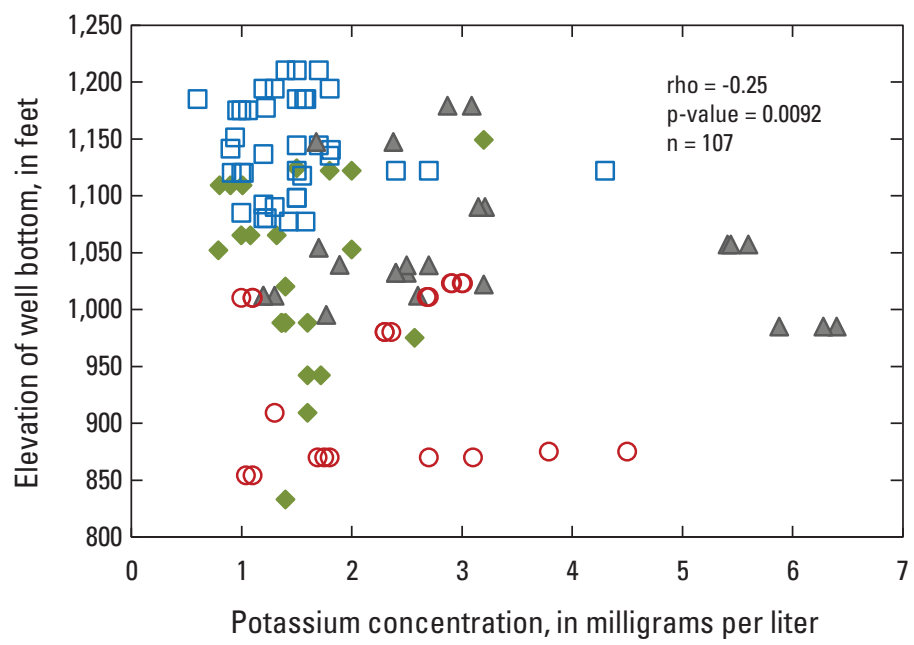

\section{EXPLANATION}

\begin{tabular}{lll}
\multicolumn{2}{c}{ Aquifer } \\
$\Delta$ Glacial deposits & $\Delta$ Cuyahoga Group \\
$\square$ Pottsville Formation & $\bigcirc$ Berea Sandstone
\end{tabular}

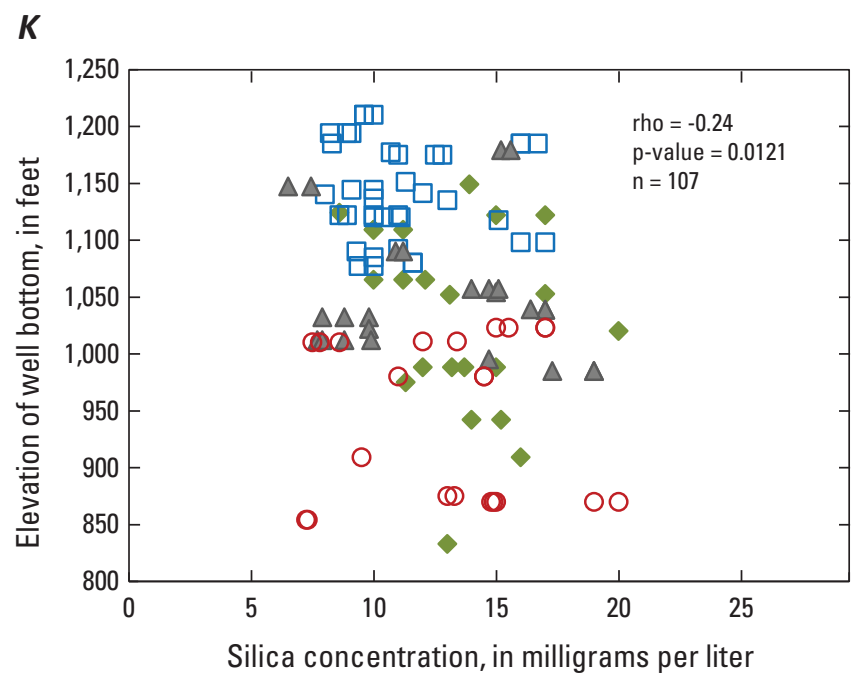

\section{$L$}

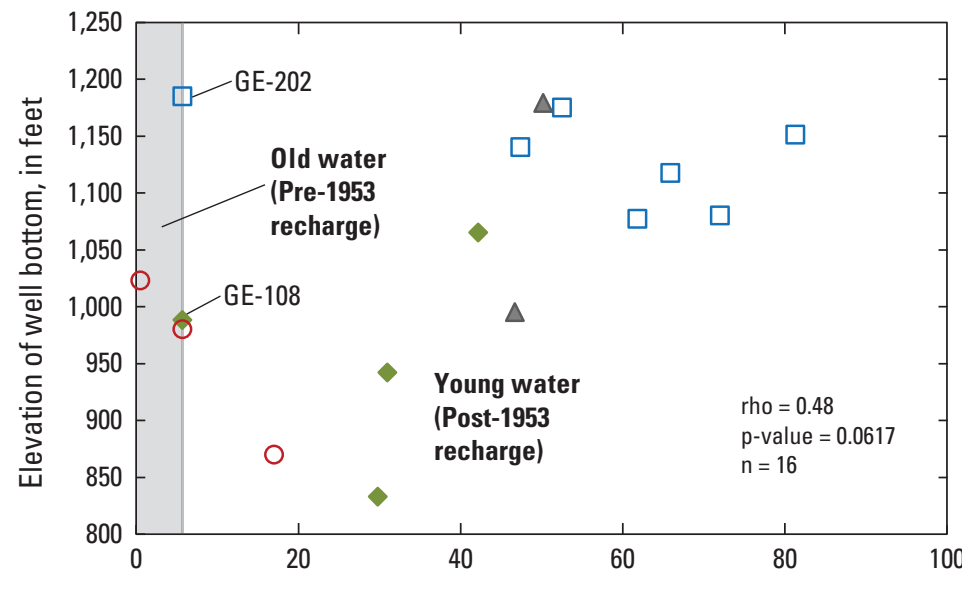

Tritium concentration in 1999, in picocuries per liter

(Tritium concentrations for samples collected in 2009 have been corrected for radioactive decay so that they reflect concentrations in 1999, when the majority of samples were collected.)

Figure 31. Relation of selected constituent concentrations to elevation of well bottom for samples collected by the U.S. Geological Survey, Geauga County, Ohio, 1978-2009. (Rho is Spearman's rho correlation coefficient; p-value is statistical significance of correlation; $\mathrm{n}$ is number of samples; $\mathrm{SMCL}$ is Secondary Maximum Contaminant Level.)-Continued 


\section{Groundwater Quality in Geauga County, Ohio-Status, 2009, and Changes During 1978-2009}

in a marine (saltwater) environment. In these two formations, sodium that adsorbed to clays at the time of aquifer deposition migrates into groundwater as calcium and magnesium cations move from groundwater to adsorption sites on clays in a process known as cation exchange. One result of cation exchange is the enrichment of sodium concentrations in samples from many wells completed in the Cuyahoga Group and the Berea Sandstone. The median sodium concentration for all samples from Cuyahoga Group and Berea Sandstone wells during 1978-2009 was $56.9 \mathrm{mg} / \mathrm{L}$, compared to a median of $7.74 \mathrm{mg} / \mathrm{L}$ for samples from wells completed in the glacial deposits and Pottsville Formation, which were at least partially deposited in a nonmarine (terrestrial) environment.

Sodium concentrations exceeding health-based benchmarks (for people limiting sodium intake) were measured in some samples from public-supply wells (tables 4 and 5) that were completed in all four aquifers, likely because public-supply wells pump at higher rates than domestic wells (2,040-385,000 gallons per day [gal/d] for public-supply wells with untreated sodium data [table 4]) compared to estimated pumping rates of about $600 \mathrm{gal} / \mathrm{d}$ for domestic wells serving a four-person household). Public-supply wells therefore draw in water from larger areas than domestic wells, potentially from surrounding formations, and more readily mobilize sodiumrich water to move along preferential flow paths that may be present (such as fractures, abandoned wells, and well bores) (Landon and others, 2009).

\section{Oxidation-Reduction Reactions}

Microbial respiration causes many chemical reactions to occur that can greatly affect the concentration in groundwater of some constituents that are present naturally in aquifer rocks and sediments. These reactions - called oxidationreduction, or redox, reactions - also influence the fate of some manmade contaminants that enter the groundwater system. Redox reactions readily occur when organic carbon is present in the aquifer. During these reactions, microbes will transfer electrons from organic carbon sequentially to the following "electron acceptors" (listed in order of preference): dissolved oxygen, nitrate, manganese (IV), iron (III), sulfate, and carbon dioxide. After one electron acceptor is consumed, microbes will then use the next most favorable electron acceptor and the redox condition of the groundwater will become more "reducing." On the basis of measured concentrations of dissolved oxygen, nitrate, manganese, iron, sulfate in a groundwater sample, the redox process(es) occurring in the part of the aquifer from which the sample is derived can be categorized according to the criteria listed in table 12. Redox conditions were characterized for 116 samples from 65 wells sampled by USGS in Geauga County during 1978-2009. These conditions are summarized in table 12 and listed by individual well in appendix table 5-1. Ideally, iron-reducing conditions would be distinguished from sulfate-reducing conditions, because some constituents behave differently in the two environments. However, for this study, iron- and sulfate-reducing waters are combined for the purposes of discussion and referred to as "strongly reducing" because the majority of samples either lacked sulfide data, which is required to distinguish between these two conditions, or did not have dissolved iron:sulfide ratios of sufficient magnitude to distinguish between the two processes.

Most groundwater samples were either strongly reducing (60 percent) or oxic (18 percent) (table 12). No samples were methanogenic, which is the most reducing redox process whereby transfer of electrons converts carbon dioxide gas and hydrogen ions in groundwater into methane. Each redox condition is associated with specific contaminants in Geauga County groundwater (table 12). Strongly reducing (iron- and [or] sulfate-reducing) waters contained many of the naturally occurring contaminants - arsenic, manganese, and ironfound to exceed health-based and aesthetically based drinkingwater standards. Strongly reducing conditions are a common geochemical trigger that releases arsenic from aquifer sediments into groundwater (Smedley and Kinniburg, 2002). This seems to be the process controlling arsenic concentrations in Geauga County groundwater, where the six oxic, suboxic, nitrate-reducing, and manganese-reducing groundwater samples for which arsenic analyses were available were associated with low concentrations of arsenic (less than or equal to $1 \mu \mathrm{g} / \mathrm{L}$ ), whereas arsenic concentrations in the 12 strongly reducing samples ranged from less than 1 to $15 \mu \mathrm{g} / \mathrm{L}$, with a median concentration of $4 \mu \mathrm{g} / \mathrm{L}$.

Nitrate was detected primarily in oxic and nitratereducing waters - redox conditions that occur only in the Pottsville Formation and Berea Sandstone. Infiltrating precipitation may encounter nitrate sources near land surface. Nitrate in water that recharges the aquifer system will persist in groundwater in oxic areas but will eventually be converted to ammonia and harmless nitrogen gas in nitratereducing environments or in waters that have more reducing conditions (see arrow, table 12). Nitrate concentrations greater than $1 \mathrm{mg} / \mathrm{L}$ are found almost exclusively in water from the Pottsville Formation ${ }^{10}$ (appendix table 4-1); wells tapping the Pottsville Formation have bottom elevations higher than 1,075 $\mathrm{ft}$ (fig. 31). Ammonia concentrations greater than $0.2 \mathrm{mg} / \mathrm{L}$ generally occur at elevations below 1,075 ft (fig. 31A).

VOCs found to be associated with specific redox conditions in a nationwide study (Zogorski and others, 2006) are listed in table 12. Only VOCs that have also been found in groundwater during Ohio EPA investigations of chemical releases in Geauga County (fig. 11) are included. VOCs are likely to persist and thus be detected more frequently in redox conditions in which they degrade slowly (Zogorski and others, 2006). In the absence of remediation, the persistence of VOCs released at some of the known groundwater contamination sites in the county (fig. 11) will be affected by the redox

\footnotetext{
${ }^{10}$ The exception to this statement is well GE-341 in Thompson Township, which is completed in the Cuyahoga Group. Samples from well GE-341 have a mixed oxic-manganese-reducing redox condition and contain 1.38-1.73 $\mathrm{mg} / \mathrm{L}$ of nitrate as $\mathrm{N}$. The well bottom elevation is $1,147 \mathrm{ft}$.
} 


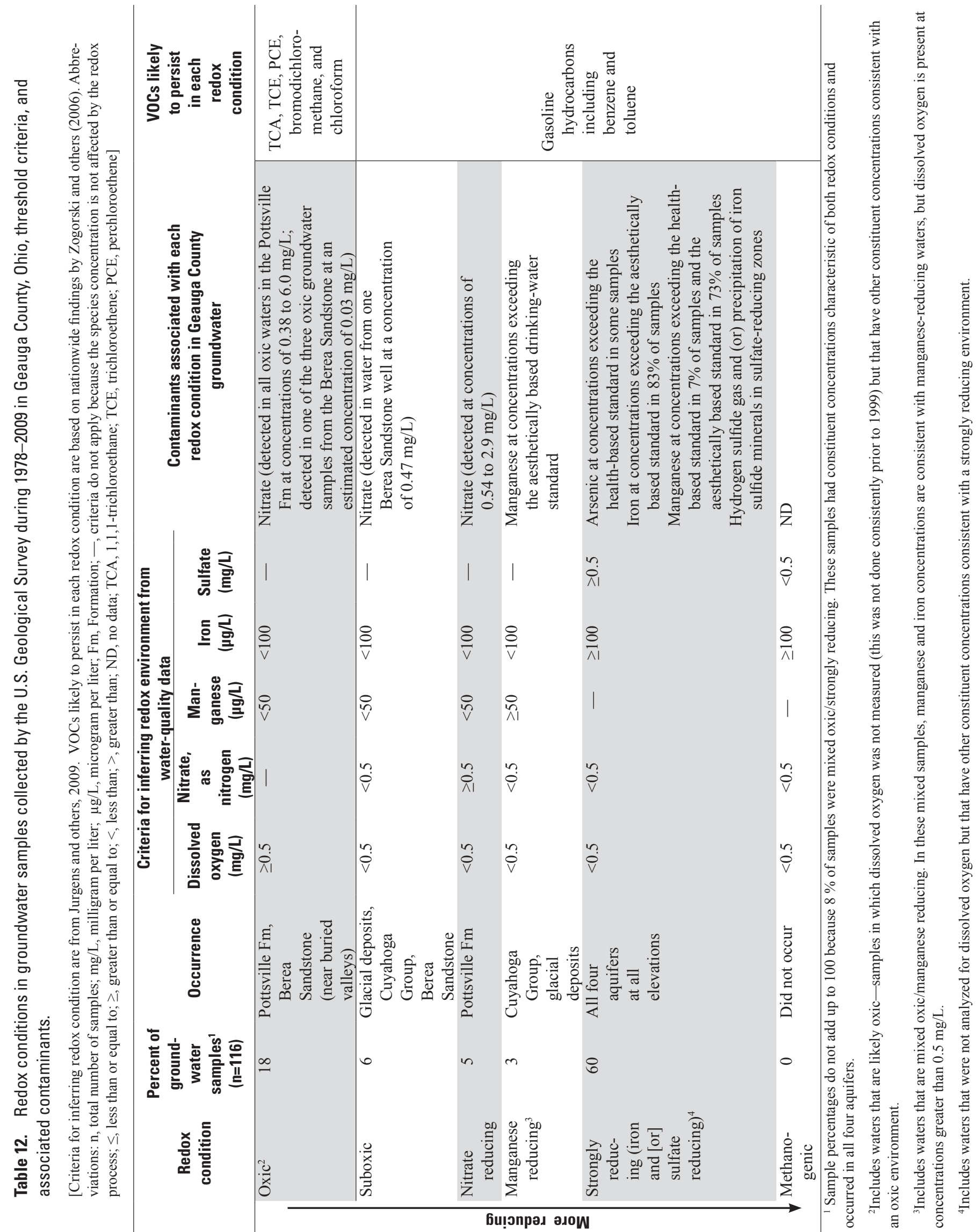




\section{Groundwater Quality in Geauga County, Ohio-Status, 2009, and Changes During 1978-2009}

condition of groundwater beneath these sites. (However, redox conditions at these sites have not been categorized by USGS personnel.)

Knowing that redox conditions control the occurrence of many contaminants, attempts were made to further document spatially where oxic and strongly reducing redox conditions were found so that contaminant occurrence can be better anticipated by planners and well owners. Also, because some, but not all, strongly reducing groundwater samples contained (a) arsenic and manganese at concentrations that can adversely affect human health or (b) sulfide at concentrations that could adversely affect drinking-water aesthetics, factors were investigated that could be used to predict where these exceedances are likely to occur. To that end, the following questions were considered:

Can areas where oxic conditions and strongly reducing conditions occur be better delineated? Because two of the aquifers - the Pottsville Formation and the Berea Sandstone - are oxic in some areas and strongly reducing in others, an effort was made to further define spatially where different redox conditions occur. First, redox conditions in the Pottsville Formation were examined. Because oxygen in groundwater is derived from infiltrating precipitation, various measures of well construction that might approximate nearness of the sampling interval to recently recharged groundwater were plotted, using color codes to indicate redox conditions. Surprisingly, a visual inspection of plots (data not shown in report) showed no relation of redox condition of samples from the Pottsville Formation to well-bottom elevation, depth of well, depth to water, or feet of water above open interval; strongly reducing samples originated from all elevations and depths. Similarly, a map showing the spatial distribution of redox conditions in the Pottsville Formation (fig. 32) showed no relation of redox condition to well position along a groundwater flow path (recharge area, mid flow path, or discharge area). Instead, it seems that redox conditions at a well location were affected by the permeability of rock and sediments overlying the Pottsville Formation in the vicinity of the well. Wells tapping strongly reducing groundwater tended to have a greater thickness of overlying low-permeability material (such as clay or shale) than wells tapping oxic or nitrate-reducing groundwater (fig. 33). In general, wells with more than about $30 \mathrm{ft}$ of overlying clay or shale produced strongly reducing water. The presence of shale overlying the Pottsville Formation was particularly diagnostic - about 30 percent of the strongly reducing samples were from areas overlain by shale, but none of the oxic or nitrate-reducing samples were. Low-permeability clay and shale inhibit recharge, leading to lower oxygen content and, consequently, more reduced waters. Clay and shale may also have higher organic carbon content than the sandstones of the Pottsville Formation, which would stimulate oxygen consumption and drive the redox environment toward reducing conditions.

Available water-quality data indicate that strongly reducing conditions are more prevalent in the Pottsville Formation in the southeastern corner of the county (fig.
32), and oxic and nitrate-reducing conditions (along with detectable nitrates in groundwater) are more prevalent in the western townships. The distribution of shale layers in and overlying the Pottsville Formation may cause this spatial pattern. Preliminary mapping data suggest that such shales are thicker than average near the center of Burton Township, are discontinuous beneath Middlefield Township, and are relatively commonplace beneath Troy and Parkman Townships, where they cause yields of wells tapping the Pottsville Formation to be lower than elsewhere in the county (Baker, 1964). In other townships, shale layers in and overlying the Pottsville Formation are thin and discontinuous because of erosion.

Next, redox conditions in the Berea Sandstone were examined. Finding oxic groundwater in the Berea Sandstone was unexpected because the Berea Sandstone is the deepest aquifer in the county and contains water that has been in the aquifer system for the longest period of time (fig. 2). The redox state of water from Berea wells was examined relative to locations of the wells. Three of the four Berea Sandstone wells that have produced oxic or suboxic samples are very near areas where the Berea Sandstone crops out (that is, where it occurs at land surface) or is covered by glacial sediments filling an ancestral stream valley, as mapped by Eberts and others (1990, plate 1). Strongly reducing wells are farther from these outcrop areas, but not so far as to be in areas overlain by shales of the Cuyahoga Group. In wells producing oxic to suboxic water, either depth to groundwater was shallow (less than $45 \mathrm{ft}$ below land surface) or the measured water level was within the open interval (uncased portion) of the well. Wells tapping strongly reducing groundwater had depths to water greater than $60 \mathrm{ft}$ and measured water levels of $15 \mathrm{ft}$ or more above the open interval of the well.

In summary, it may be of interest to planning officials and (or) homeowners to know whether groundwater in areas underlain by sandstone is likely to be oxic (a geochemical environment where nitrate and chlorinated VOCs such as TCE and PCE are likely to persist) or strongly reducing (an environment where dissolved arsenic may be present at concentrations above the health-based benchmark and where gasoline hydrocarbons, such as benzene and toluene, are likely to persist). Clues to the groundwater redox condition may be provided by drillers' well logs (available online at https://apps. ohiodnr.gov/water/maptechs/wellogs/appNEW/Default.aspx) used in conjunction with land-surface elevation data from a topographic map. Well-bottom elevation can be determined by subtracting total well depth from land-surface elevation. If the well is open to (uncased through) a sandstone aquifer and the well-bottom elevation is greater than about $1,075 \mathrm{ft}$, the well is likely completed in the Pottsville Formation (fig. 31). If the log for such a well shows $30 \mathrm{ft}$ or more of clay or shale overlying the sandstone aquifer, groundwater is likely to be strongly reducing (fig. 33) - particularly if shale is present. If the well-bottom elevation is between about 850 and $1,025 \mathrm{ft}$ (fig. 31) and the well is open to a sandstone aquifer, it is the Berea Sandstone. For Berea wells, if the static water level 


\section{EXPLANATION}

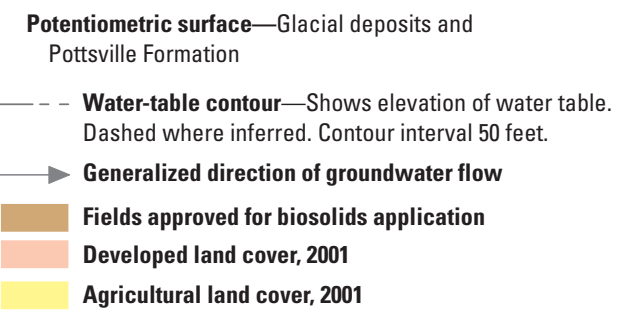

Potentiometric surface-Glacial deposits and

Pottsville Formation

Water-table contour-Shows elevation of water table.

Fields approved for biosolids application

Agricultural land cover, 2001

Nitrate concentration for wells in Pottsville Formation (milligrams per liter)

Oxic and nitrate-reducing wells

- $0.18-0.99$

(2) $1.0-2.99$

(3.0-6.0

Iron and (or) sulfate-reducing wells

$\nabla<0.18$

$\nabla \quad 0.18-0.99$

$\nabla \quad 1.0-2.99$
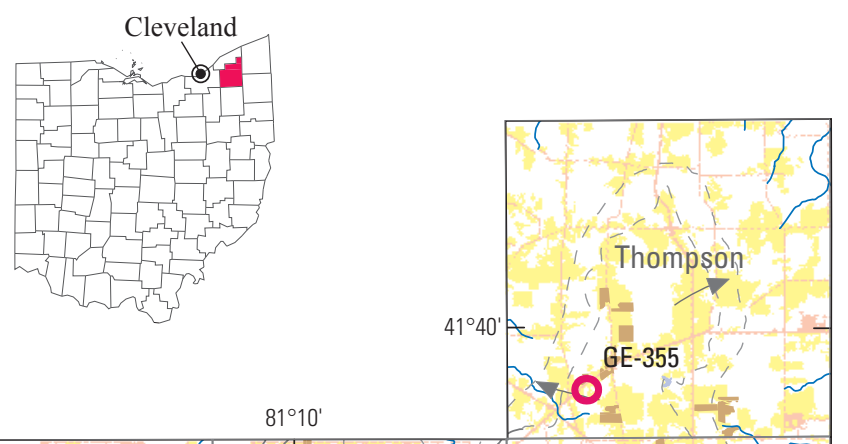


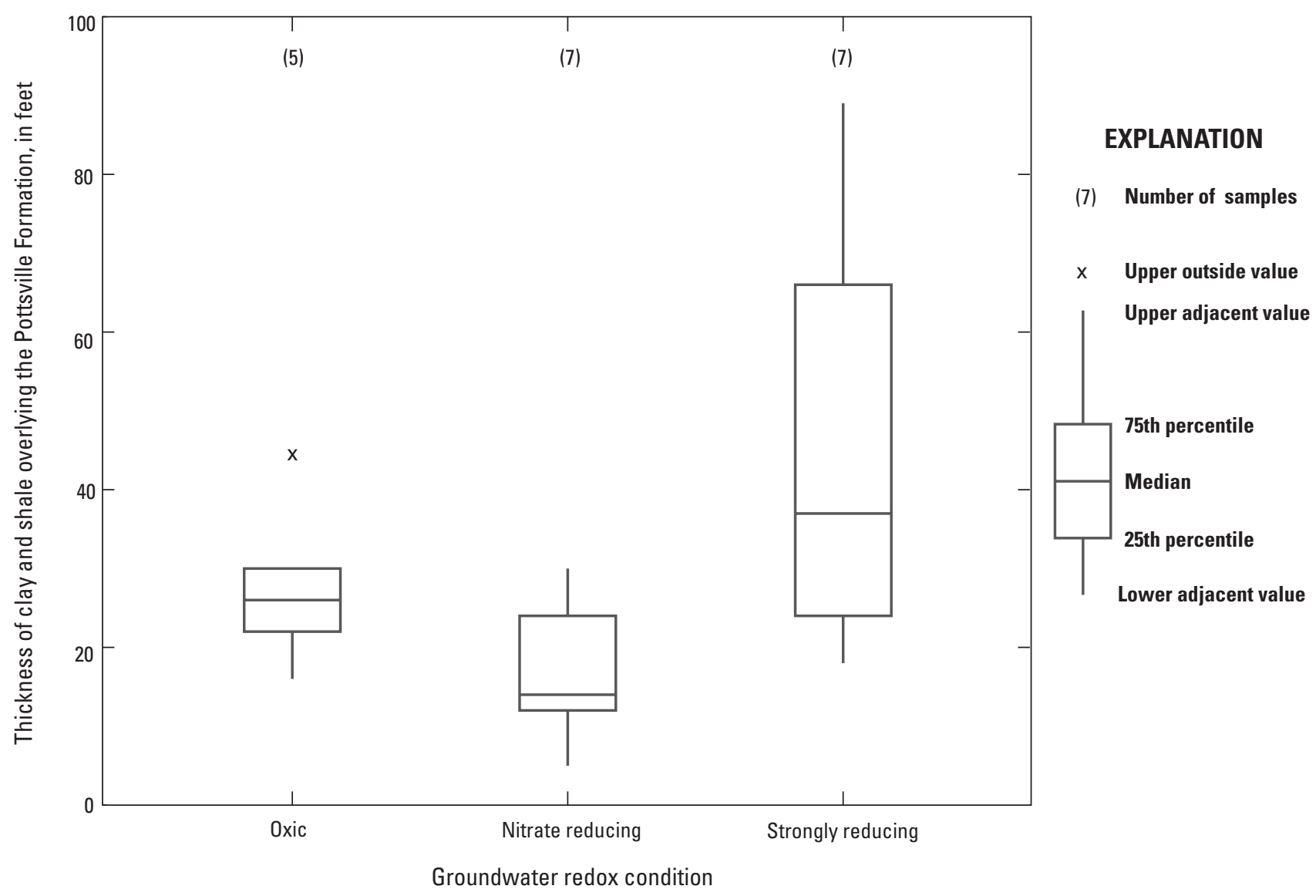

Figure 33. Thickness of clay and shale overlying the Pottsville Formation in Geauga County, Ohio, by groundwater redox condition at sampled well locations, 1978-2009.

listed on the well log is less than $45 \mathrm{ft}$ below land surface or is within the uncased portion of the well, the redox condition of groundwater is likely to be oxic. If the static water level is greater than about $60 \mathrm{ft}$ below land surface and is $15 \mathrm{ft}$ or more above the bottom of the well casing, the groundwater is likely to be strongly reducing.

What factor(s) cause concentrations of arsenic in strongly reducing groundwater to exceed health-based benchmarks in some areas and not in others? To answer this question, strongly reducing waters in all aquifers were examined. Wells producing strongly reducing water that exceeds the health-based benchmark for arsenic (prior to treatment) included two domestic wells (GE-108 and GE-202) and public-supply wells in Middlefield Village and Chardon ${ }^{11}$

\footnotetext{
${ }^{11}$ Public-supply wells in Middlefield and Chardon were sampled by the USGS in 1980 (wells GE-42 and GE-53Q, appendix table 4-1). USGS water-quality data for these wells were used to create figure 34; however, arsenic concentrations exceeding the human-health benchmark have also been documented by Ohio EPA water-quality monitoring programs at these wells (tables 4 and 5).
}

(fig. 34). Three of these wells tap the glacial deposits, and one well, GE-202, draws water from the Pottsville Formation. There is no evident spatial pattern to the wells with elevated arsenic that suggests that glacial sediments or bedrock in a particular area are arsenic enriched (fig. 34). Stratigraphic data from these four wells and statewide data (p. 33) indicate that arsenic occurs at concentrations exceeding the health-based benchmark more often in sand and gravel aquifers (which includes glacial deposits) than in sandstone aquifers (such as the Pottsville Formation or the Berea Sandstone). However, a literature review of arsenic concentrations in 32 compliance samples from public-supply wells in Bainbridge Township (Ohio Department of Natural Resources, 2008b) found that aquifer type was not a reliable risk factor. Although most groundwater samples considered by ODNR were below the health-based benchmark of $10 \mu \mathrm{g} / \mathrm{L}$, at least one sample from each of the following formations exceeded health-based standards: the Pottsville Formation, the Cuyahoga Group (maximum concentration of $20 \mu \mathrm{g} / \mathrm{L}$ in both formations), and the Berea Sandstone (maximum concentration of $24 \mu \mathrm{g} / \mathrm{L}$ ). 


\section{EXPLANATION}

Redox process (see appendix table 5-1) - If the redox process has changed over time at a well, the top symbol represents the most recent sample.

0xic, suboxic, or nitrate or manganese reducing

§ Mixed oxic-anoxic

$\nabla \quad$ Strongly reducing

Manganese concentration greater than 300 micrograms per liter $(\mu \mathrm{g} / \mathrm{L})$

Arsenic concentration greater than $10 \mu \mathrm{g} / \mathrm{L}$

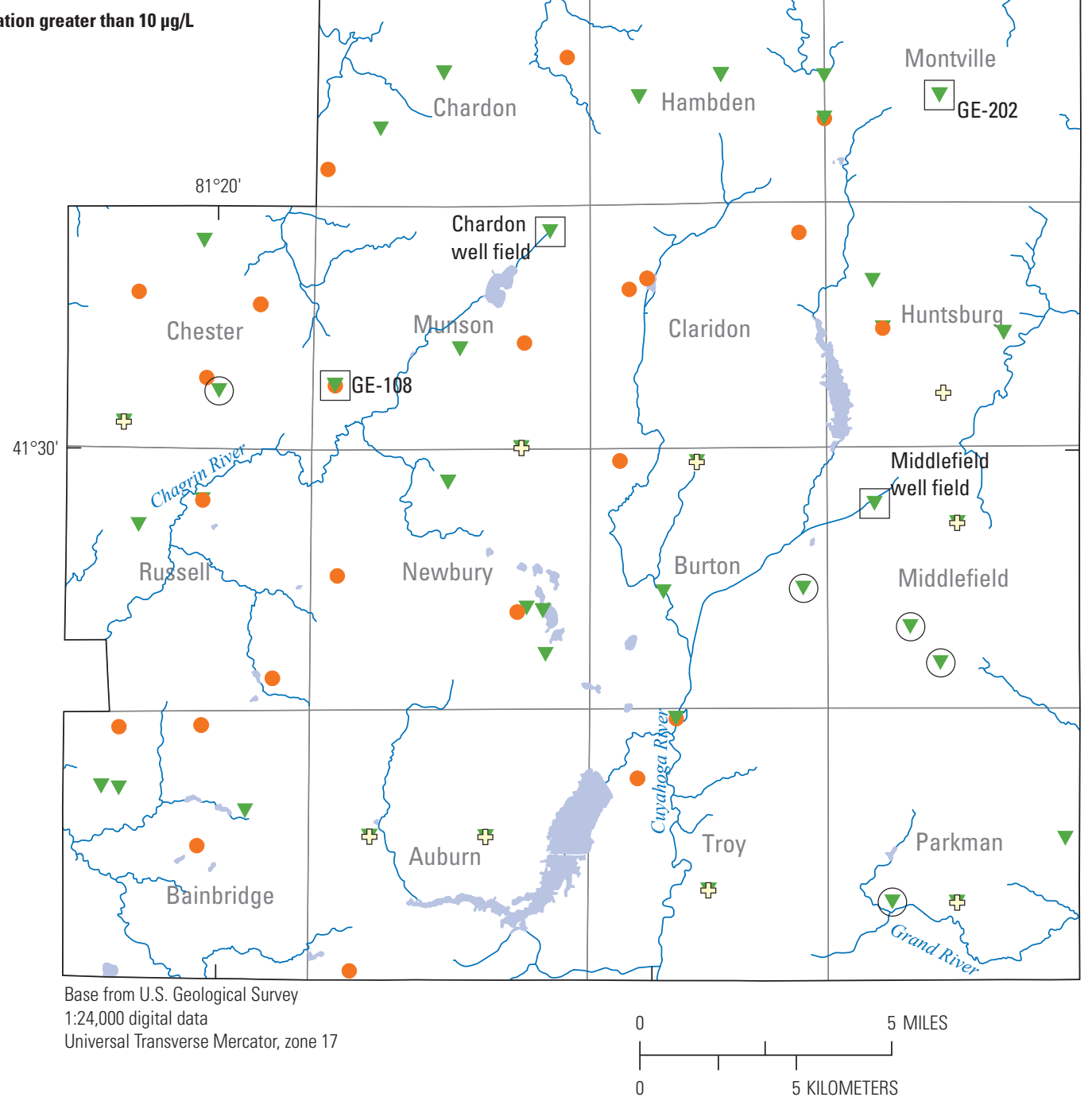

Figure 34. Locations of wells tapping a strongly reducing groundwater environment relative to locations of wells with samples that have exceeded the health-based benchmarks for arsenic or manganese, for wells sampled by the U.S. Geological Survey, Geauga County, Ohio, 1978-2009. 


\section{Groundwater Quality in Geauga County, Ohio-Status, 2009, and Changes During 1978-2009}

Groundwater age (or time since water recharged the groundwater system) is a factor that has been found to influence arsenic concentrations in other study areas (Smedley and Kinniburg, 2002; Thomas, 2007). Thomas (2007) noted that for wells tapping the glacial aquifer system in the northern United States (which includes the glacial deposits in Geauga County), the likelihood of arsenic exceeding the health-based standard in strongly reducing water was increased if the water samples were old (pre-1953 recharge as indicated by lack of measureable tritium). Old groundwater can indicate sluggish groundwater flow. Smedley and Kinniburg (2002) suggested that slow-moving flow does not flush away arsenic after it is released from aquifer sediments, allowing it to accumulate in groundwater. Findings in Geauga County were consistent with those of Smedley and Kinniburg (2002) and Thomas (2007). Wells GE-108 and GE-202 are the only two wells completed in a formation other than the Berea Sandstone for which both arsenic and tritium data are available and for which tritium concentrations are indicative of pre-1953 recharge (fig. 31L). Well logs provide clues as to why these two wells would produce older water than other wells in the same aquifers. GE-202 is the only Pottsville well sampled in 2009 (the year all samples were analyzed for arsenic) at a location where the aquifer is overlain by shale, which likely inhibits recharge. GE-108 is one of the deepest glacial wells sampled (132 ft below land surface), and is overlain by $83 \mathrm{ft}$ of clay, which would also limit recharge relative to other wells. Permeability of overlying materials seems to affect arsenic concentrations more than well construction, as there was no statistically significant relation of arsenic concentration to well depth or wellbottom elevation when considering the 22 arsenic samples collected by USGS personnel in the county (1978-2009) for which well-depth information was available (appendix table 4-1).

What factor(s) cause concentrations of manganese in strongly reducing groundwater to exceed health-based benchmarks in some areas and not in others? Only 5 out of 70 strongly reducing samples collected by the USGS (appendix table 5-1) have historically (1978-1999) exceeded the health-based benchmark for manganese $(300 \mu \mathrm{g} / \mathrm{L})$ (appendix table 4-1). The small number of exceedances indicates that redox condition is not the sole process causing elevated manganese in groundwater. Four of the five samples with manganese concentrations above $300 \mu \mathrm{g} / \mathrm{L}$ are from wells clustered in Burton, Middlefield, and Parkman Townships in the southeastern part of the county (fig. 34); most of these wells produce water from the Pottsville Formation. In the past, Ohio EPA personnel investigated groundwater in southwestern Middlefield Township (Ohio Environmental Protection Agency, 1995; Bolas and Mohr, 1995) - mostly in the Pottsville Formation - and concluded that elevated manganese in groundwater in this area is naturally occurring rather than caused by human contamination, with concentrations in samples from a total of 28 wells ranging from less than $10 \mu \mathrm{g} / \mathrm{L}$ to as high as 4,060 $\mu \mathrm{g} / \mathrm{L}$. Bolas and Mohr concluded that this "elevated pocket" of manganese in groundwater was due to reducing groundwater conditions plus one or all of the following: (1) the manganese content of the Pottsville Formation being higher here than in other areas of the county, (2) the manganese content of the glacial till overlying the Pottsville Formation being higher here than in other areas, and (3) the $\mathrm{pH}$ of groundwater in this area favoring the dissolution of manganese from aquifer sediments. The observation that manganese dissolves in acidic water and precipitates as water acidity is neutralized has been documented by other researchers (Hem, 1989). Of all 51 manganese-reducing or strongly reducing wells (or mixed oxic/ anoxic wells) sampled by the USGS in Geauga County having manganese concentrations less than $300 \mu \mathrm{g} / \mathrm{L}$, the median $\mathrm{pH}$ was 7.2 (range 4.7-7.7). The median $\mathrm{pH}$ for the five wells with manganese concentrations greater than $300 \mu \mathrm{g} / \mathrm{L}$ was more acidic, at 6.6 (range 6.0-6.9).

Can zones where hydrogen sulfide gas and iron sulfide precipitates are present be further delineated? Hydrogen sulfide gas and (or) iron sulfide precipitates occur in sulfatereducing conditions (a subset of strongly reducing groundwater). During sulfate reduction, dissolved sulfate is converted to hydrogen sulfide gas or to iron sulfide minerals that precipitate from groundwater and appear as finely disseminated black particulates that can accumulate in well bottoms and pressure tanks. Eighteen percent of the 116 water samples collected by the USGS during 1978-2009 (appendix table 4-1) were determined to have some sulfate reduction occurring. (Note that this percentage is a minimum value, because total sulfide - which is necessary to distinguish between sulfate- and iron-reducing redox environments - was not measured during the 1978 and 1980 sampling rounds and was not consistently measured in 1986). Although sulfate-reducing conditions were found in all four aquifers in the county, sulfide occurred at only low concentrations (less than $0.1 \mathrm{mg} / \mathrm{L}$ ) in the Pottsville Formation. Concentrations greater than $0.1 \mathrm{mg} / \mathrm{L}$ were found at elevations below $1,060 \mathrm{ft}$ in some, but not all, wells that tap the glacial deposits, Cuyahoga Group, or Berea Sandstone (fig. 31G).

Total sulfide concentrations were correlated to turbidity for the 16 domestic well samples collected in 2009 (rho $=0.48$, $\mathrm{p}$-value $=0.0582$ ). This could be because (1) precipitating iron sulfide minerals added turbidity (particulates) to groundwater or (2) hydrogen sulfide gas (a component of total sulfide) corroded the casings of wells, allowing soil or sediment to enter the wells and resulting in turbid water. However, independent indicators that soil and sediment have entered wells with elevated sulfide content, such as correlation of silica or organic carbon to turbidity, are not present.

\section{Stratigraphic Traps That May Control Areas of Methane Accumulation}

Methane in groundwater can be introduced from either microbial or thermogenic sources (Baldassare and Laughrey, 1997). Microbial sources include methane generated under very reducing (methanogenic) redox conditions or from 
decomposition of landfill wastes. Thermogenic sources consist of organic matter deeply buried under sediments where elevated temperatures facilitate decomposition of the organic matter to petroleum and methane. Thermogenic gas can escape naturally from deep oil and gas reservoirs through fractures, or it can be released by humans during oil- and gas-drilling accidents, from pipelines, or from abandoned production wells. The Ohio Shale, which lies below the Berea Sandstone and the Bedford Shale, is a known natural gas source rock that has been evaluated by the U.S. Department of Energy (Hoover, 1960; Janssens and de Witt, 1976; Schwietering, 1979) and could be a source of naturally occurring gas to water wells in Geauga County. However, no stable-isotope analyses were done as part of the current study that can be used to determine which of these sources of methane is reaching water wells in Geauga County.

Regardless of the source, free-phase (exsolved) gas will move from areas of higher pressure to areas of lower pressure. This can result in upward movement of gas through permeable rocks, joints, and fractures until it reaches a relatively impermeable layer of rock. In the Bainbridge Township area (fig. 11), gas released by drilling in 2007 initially migrated rapidly upwards until it reached the top of the Berea Sandstone, where it was temporarily trapped beneath the less permeable Cuyahoga Group. Once at the top of the Berea Sandstone, the buoyant gas migrated upslope, toward a high point at the top of the Berea Sandstone (a dome-shape structure north of the house that exploded). Over time, gas slowly worked its way upward through fractures in the Cuyahoga Group and concentrations in the Berea Sandstone diminished (Bair and others, 2010).

It is possible that occurrences of methane in water wells elsewhere in the county could be related to the position of the wells relative to structural highs on the top of the Berea Sandstone. Figure 35 shows the elevation of the top of the Berea Sandstone in Geauga County based on data obtained from drilling logs. This map was created by ODNR in 1981 using a limited number of data points. Where data points were more dense, a structural high was discerned that underlies GE-147, one of the USGS-sampled wells found to contain dissolved methane. Few data points exist near the location of the other two wells in which methane was detected by USGS personnel, or in Bainbridge Township where a structural high was mapped by ODNR-MRM personnel using additional data (Bair and others, 2010). If this hypothesis is correct, structural highs on the top of the Berea Sandstone could temporarily trap both gas that is naturally occurring (for instance, gas migrating upwards from the Ohio Shale) and gas released by drilling activities targeting deeper reservoirs.

Pumping of groundwater also can create areas of low pressure within the aquifer. The two wells found to contain the higher concentrations of methane in the current study, wells GE-126 and GE-147, had experienced significant declines in water level from 1986 to 2009 (28.85 and $17.26 \mathrm{ft}$, respectively) (http://nwis.waterdata.usgs.gov/oh/nwis/gwlevels). These were the two largest changes in water level observed out of the 16 wells sampled. Lowering of water level reduces the pressure from overlying water in an area and can cause gas in an aquifer to preferentially migrate to these areas of low pressure.

\section{Considerations for Future Work}

During this study, some observations were made and factors were identified that are thought to affect water quality but that could be clarified by further geologic mapping in the county:

- The use of geographic information systems (GIS) software to analyze existing maps of groundwater levels (Jagucki and Lesney, 1995, plates 2-4) and land-surface elevations to produce a map of depth to groundwater along roads in the county could identify the areas where the sparing use of road-deicing chemicals would provide the improved protection of groundwater quality.

- Preliminary evidence suggests that shale units within and overlying the Pottsville Formation are associated with areas of elevated concentrations of iron, manganese, and arsenic in groundwater relative to areas in Pottsville Formation where the shale is not present. Mapping of these shale units may provide insight into (a) areas of the Pottsville Formation that are vulnerable to elevated concentrations of these constituents and (b) areas that likely receive lower recharge and may require more sparing water use.

- Mapping of structurally high areas on top of the Berea Sandstone may help identify areas in the county that are vulnerable to methane accumulation in water wells. 
70 Groundwater Quality in Geauga County, Ohio-Status, 2009, and Changes During 1978-2009

\section{EXPLANATION}

\section{_ Elevation of top of Berea Sandston}

II//III Approximate location of Berea Sandstone outcrop or subcrop beneath glacial deposits -From Eberts and others, 1990, pl.1

Streams

Lakes

GE-108 Water-quality site and well name for wells sampled by the U.S. Geological Survey in 2009 (see table 3)

Wells in which methane was detected in June 2009

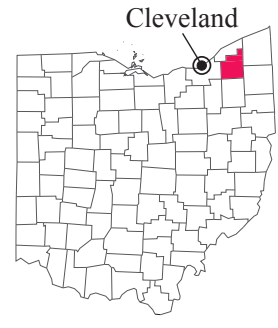

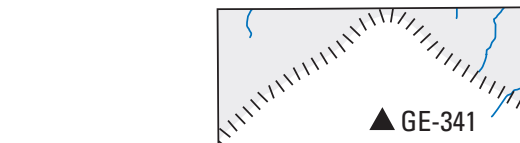

Thompson

$41^{\circ} 40^{\prime}$
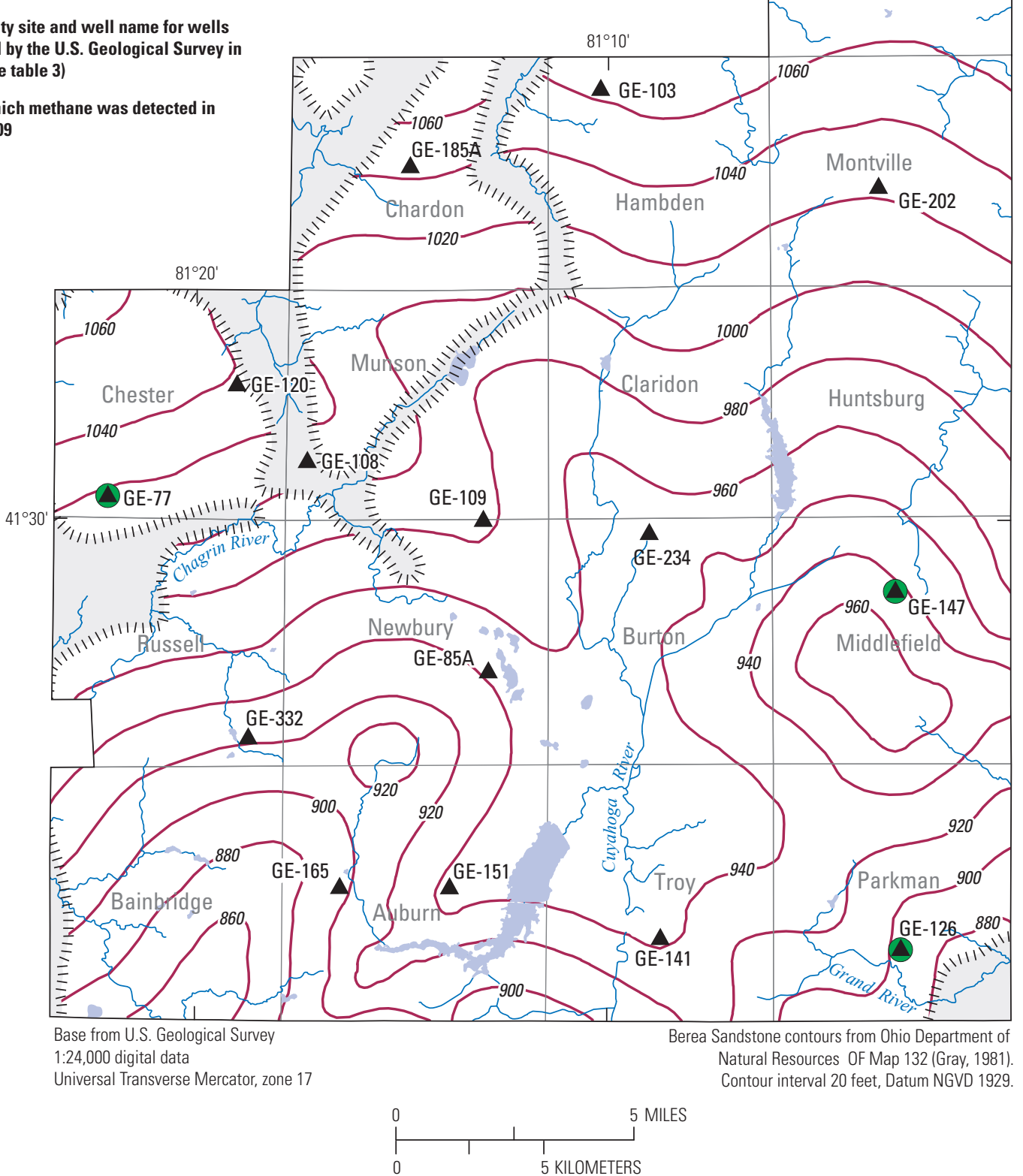

Figure 35 Elevation of top of the Berea Sandstone in Geauga County, Ohio, and location of methane detections, June 2009 . 


\section{Summary and Conclusions}

Groundwater in Geauga County, Ohio, is an important resource because it is the main drinking-water supply for over 98 percent of residents in the county. For the past three decades, the U.S. Geological Survey (USGS) has worked together with Board of Commissioners and the Geauga County Planning Commission to evaluate the potential effects of human development and changing land use on the quantity and quality of the county's groundwater resources. The purpose this most recent study was to (1) describe the status of groundwater quality in 2009 in the four primary aquifers used in the county - the glacial deposits, the Pottsville Formation, the Cuyahoga Group, and the Berea Sandstone, (2) describe the detection frequency of methane in water wells in the county in 2009, and (3) determine whether statistically significant changes in water quality had occurred since 1978.

Increasing population brings with it a greater potential for harmful human effects on groundwater resources. Population in Geauga County increased by more than 72,000 people between 1950 and 2009, with almost half of the growth occurring in the 1950s and 1960s. Likely because of this rapid population growth and associated increased water use, ongoing water-level declines were noted in several long-term waterlevel network wells in the late 1970s and 1980s that stabilized by the mid-1990s. Declines occurred at wells in several townships and in wells tapping each of the four primary aquifers. Such water-level declines can potentially affect water quality by causing a well to withdraw water from different parts of an aquifer than were accessed previously. Other prevalent human activities in the county with the potential to adversely affect groundwater quality include (1) septic systems used by 70 percent of homes to treat domestic sewage and wastewater, (2) spreading of septage (solids and liquids pumped from septic tanks) and biosolids (treated sludge from wastewater treatment plants) on agricultural fields in the eastern part of the county, (3) oil-field drilling that resulted in 1,112 producing oil and (or) gas wells as of 2008, and (4) the addition of 157 miles of township roads between 1981 and 2008 that led to greater amounts of road salt being purchased over time by the County Engineer for application to remove snow and ice.

As of 2010, ten known areas of localized groundwater contamination in the county - most associated with commercial and industrial activities - had been documented by either the Ohio Environmental Protection Agency (Ohio EPA) Division of Drinking and Ground Water or Division of Environmental Response and Restoration or the Ohio Department of Natural Resources, Division of Mineral Resources Management (ODNR-MRM). Contaminants in these areas are typically chlorinated VOCs, gasoline compounds, and (or) road salt, and, in one case, methane. Remediation has occurred or is underway at most of these sites to remove harmful constituents from groundwater.

To determine the status of groundwater quality in 2009, the USGS collected samples from 16 domestic wells during June 9-19. All samples were analyzed for specific conductance, $\mathrm{pH}$, turbidity, dissolved oxygen, major ions, alkalinity, total sulfide, nutrients, iron, manganese, arsenic, dissolved organic carbon, pesticides, total coliform, and Escherichia coli (E. coli) bacteria. Selected samples were also analyzed for fecal streptococci, fecal coliform bacteria, trace metals, and tritium.

Forty-one of the 92 parameters analyzed had humanhealth benchmarks against which analytical results could be compared to evaluate suitability for drinking. Four of these benchmarks were exceeded at the following frequencies: arsenic ( 2 of 16 wells, 12.5 percent), total coliform bacteria ( 2 of 16 wells, 12.5 percent), fecal coliform bacteria ( 1 of 14 wells, 7 percent), and sodium ( 6 of 16 wells, 38 percent). No domestic wells sampled in 2009 exceeded the health-based benchmark for manganese, although 5 of 65 wells ( 8 percent) sampled since 1978 have. Analyses from domestic wells were augmented with water-quality data from seven public-supply wells or well fields that were obtained from Ohio EPA. These public-supply data were typically collected between 2000 and 2010. Similar to the domestic well data, these data indicated that some samples from public-supply wells have also exceeded health-based benchmarks for arsenic and sodium, along with occasional exceedances of health-based benchmarks for cadmium and lead.

Concentrations of nitrate, pesticides, and VOCs were either low or not detected in groundwater samples from domestic and (or) public-supply wells. The maximum measured nitrate concentration of 1.73 milligrams per liter $(\mathrm{mg} / \mathrm{L})$ in water from 16 domestic wells sampled in 2009 was considerably less than the human-health benchmark of $10 \mathrm{mg} / \mathrm{L}$. None of the pesticides with an established human-health benchmark that were included in analyses of groundwater samples from five of the seven public-supply well fields (2,4-D, alachlor, atrazine, carbofuran, diquat, endothall, glyphosate, metolachlor, metribuzin, oxamyl, picloram, or simazine) were detected between 2000 and 2010. Similarly, of the 52 pesticides included in the USGS analyses of water from domestic wells, only the herbicide atrazine was detected at a concentration above the laboratory reporting level. Atrazine was detected in one well at a concentration of 0.0073 microgram per liter $(\mu \mathrm{g} / \mathrm{L})$, which is below the health-based drinking water standard of $3 \mu \mathrm{g} / \mathrm{L}$. This well had the largest area of upgradient agricultural land use of any well sampled. Also, depth to groundwater at this well was very shallow (less than 10 feet [ft] below land surface), adding to its vulnerability.

Although no samples from domestic wells were analyzed for VOCs during the current study, water from the seven public-supply wells - both untreated and treated sampleswere analyzed for almost 100 VOCs between 1995 and 2009. With one exception, only chlorination byproducts were detected in water produced by these wells, but they were at concentrations below health-based benchmarks. Chlorination byproducts do not occur naturally in groundwater but form when chlorine added to disinfect water combines with organic matter inherently present in the groundwater. The one VOC detected in any of the studied public-supply wells that was not 


\section{Groundwater Quality in Geauga County, Ohio-Status, 2009, and Changes During 1978-2009}

a chlorination byproduct was total xylenes (a solvent that is a component of gasoline). Total xylenes were detected in 2 of 34 samples from a public-supply well field in a developed and densely populated area of Bainbridge Township. Concentrations did not exceed the human-health benchmark $(10 \mathrm{mg} / \mathrm{L})$ for this constituent.

Water-quality data collected in 2009 were also compared to Secondary Maximum Contaminant Levels (SMCLs) developed by the U.S. Environmental Protection Agency for constituent concentrations that affect drinking-water aesthetics. Iron and manganese were the constituents that most frequently exceeded SMCLs in groundwater of Geauga County (in samples from 10 of 16 domestic wells and in untreated water from 3 of 4 public-supply wells). Concentrations of iron and manganese above the SMCL may cause staining of fixtures and laundry. Although no SMCL is established for total sulfide (which includes hydrogen sulfide gas with its characteristic rotten-egg odor and iron sulfide minerals that appear as finely disseminated particulates in water), this undesirable constituent was detected in half of the 16 domestic wells sampled.

To evaluate the frequency of water wells that produce natural gas in the county, the USGS (1) screened 16 wells across the county for combustible gas fraction at the wellhead and in the headspace of water samples and (2) analyzed samples for dissolved gases in which combustible gas was detected or in which exsolving gases were observed during sampling. Combustible gas was not detected immediately below the well cap at any of the 16 wellheads screened by USGS personnel. Yet when water was pumped from each well and the air above the water (headspace) in a closed container was analyzed, water from three of the wells (19 percent) was found to contain detectable combustible gas ( 0.10 to 0.40 percent by volume). All three detections were in wells tapping the Cuyahoga Group or the Berea Sandstone, and these detections were all less than the lower explosive limit of 5 percent by volume - the concentration at which methane in air can be flammable if an ignition source is present. Analyses of dissolved gas composition in water from these three wells showed methane concentrations ranging from 0.0065 to $1.88 \mathrm{mg} / \mathrm{L}$.

To evaluate whether concentrations of frequently detected constituents consistently increased or decreased over time, the strength of the association between sampling year (time) and constituent concentration was statistically evaluated for 116 water-quality samples collected by the USGS in 1978, 1980, 1986, 1999, and 2009 from a total of 65 wells (generally domestic wells or ones serving small businesses or churches) across the county. Results indicate that many of the constituents that were analyzed for decades exhibited no consistent temporal trends at a statistically significant level ( $\mathrm{p}$-value less than 0.05); fluctuations in concentrations of these constituents represent natural variation in groundwater quality. Dissolved oxygen, calcium, and sulfate concentrations and chloride:bromide ratios increased over time in one or more aquifer, while $\mathrm{pH}$ and concentrations of bromide and dissolved organic carbon decreased over time. None of these constituents have a health-based benchmark against which to assess water-quality changes, but aesthetically based standards have been established for sulfate and $\mathrm{pH}$. Whereas sulfate concentrations are still well below the SMCL, a continued downward trend in $\mathrm{pH}$ in future years, if it occurs, could cause a greater number of samples fall below the recommended $\mathrm{pH}$ range of 6.5-8.5. Detections of total coliform bacteria and nitrate did not become more frequent from 1986 to 2009 , even though potential sources of these constituents, such as number of septic systems (linked to population) and percent developed land in the county, increased during this period. The evaluation of temporal trends by aquifer found that constituent concentrations in samples from the Berea Sandstone were largely unchanged over time, which is consistent with tritium agetracer data and simulations of groundwater flow from previous studies indicating that water in the Berea Sandstone generally entered the groundwater system prior to 1953, before most of the county's population growth and development occurred. In contrast, samples from Cuyahoga Group had the greatest number of constituents with concentrations exhibiting temporal trends.

The primary effect of human activities on groundwater quality found during this study is the input of salinity (chloride) at land surface. The main sources of chloride near land surface are road salt and septic leachate rather than surface spills of brine produced during oil-field drilling or spraying of roads with oil-field brine for dust control, based on ratios of chloride to bromide. The correlation of chloride concentration to distance of well from road for 31 wells sampled in 1999 suggests that road salt is the dominant source of chloride.

Inputs of sulfate at land surface were also identified on the basis of decreases in concentrations of sulfate with depth that did not appear to be a function of the redox condition of groundwater. A likely source of sulfate is the combustion of fossil fuels, which produces sulfate ions and acidity in rainfall of northeastern Ohio.

Only one well sampled in 2009 (GE-141) was within 500 meters downgradient of a field authorized for biosolids spreading (9.9 acres permitted to the McFarland Creek Wastewater Treatment Plant). This was also the only well where total coliform concentrations increased from 1999 to 2009, and where total coliforms co-occurred with a fecal coliform detection, a finding that strengthens the likelihood that water from this well has been affected by human or animal waste. However, further investigation determined that, if land application of biosolids from the wastewater treatment plant ever happened, it occurred prior to 2006. Documented die-off rates of fecal coliform bacteria are on the order of weeks, not years, so it is much more likely that this well is influenced by leachate from on-lot septic systems used in this area than by past spreading of biosolids. 
Most of the constituents exceeding human-health benchmarks and aesthetic standards are ones that are naturally present in aquifer sediments and rocks in Geauga County. Concentrations of these constituents in groundwater are controlled by the following natural geochemical processes in the subsurface:

- Evolution of groundwater along a flow path-As water moves from higher to lower elevations along a groundwater flow path, it dissolves minerals from aquifer rocks and sediments, causing concentrations of $\mathrm{pH}$, alkalinity, potassium, sodium, silica, fluoride, boron, specific conductance, and total dissolved solids to increase in groundwater at lower elevations.

- Cation exchange-In the Cuyahoga Group and the underlying Berea Sandstone, sodium ions that adsorbed to clays at the time of aquifer deposition migrate into groundwater as they are replaced by other cations moving from groundwater to adsorption sites on clays. The result is enriched sodium concentrations in groundwater produced by wells tapping the Cuyahoga Group and the Berea Sandstone (median concentration of $56.9 \mathrm{mg} / \mathrm{L}$ for the period 1978-2009) compared to water from wells tapping the glacial deposits and Pottsville Formation (median concentration of $7.74 \mathrm{mg} / \mathrm{L}$ ).

- Oxidation-reduction (redox) geochemical reactions-These microbially induced reactions control concentrations of dissolved oxygen, nitrate, ammonia, manganese, iron, arsenic, sulfate, and sulfide. On the basis of measured concentrations of 5 constituents in 116 groundwater samples collected during 1978-2009, the dominant redox reaction occurring in the part of the aquifer from which the samples were withdrawn was categorized. Results indicate that most groundwater samples (60 percent) were strongly reducing. Elevated concentrations of arsenic, iron, manganese, and sulfide (present either as hydrogen sulfide gas or as precipitating iron sulfide minerals) are associated with this type of redox environment, which occurred in all four aquifers. Eighteen percent of samples - only ones from the Pottsville Formation or the Berea Sandstone-were oxic. Nitrate (maximum concentration of $6.0 \mathrm{mg} / \mathrm{L}$ ) was detected in this type of environment. No samples were categorized as methanogenic (methane producing).
Because some samples from the Pottsville Formation and the Berea Sandstone are strongly reducing and others are oxic, attempts were made to further document spatially where these two redox conditions occur so that contaminant occurrence can be better anticipated by planners and well owners. Wells tapping strongly reducing groundwater in the Pottsville Formation tended to have a greater thickness of overlying low-permeability material such as clay and shale than wells tapping oxic or nitrate-reducing groundwater in the same aquifer. Spatial analysis of water-quality data indicate that strongly reducing conditions may be more prevalent in the Pottsville Formation in the southeastern corner of the county, and oxic and nitrate-reducing conditions may be more prevalent in the westernmost townships. In the Berea Sandstone, oxic or suboxic water is more prevalent in locations very near areas where the Berea Sandstone crops out (where it is exposed and visible at land surface) or is covered by glacial sediments filling an ancestral stream valley. Strongly reducing wells are located farther from these outcrops. Examination of relation of redox conditions to well characteristics indicates that oxic conditions in the Berea Sandstone were found at well locations where either depth to groundwater was shallow (less than 45 $\mathrm{ft}$ below land surface) or the measured water level was within the open interval (uncased portion) of the well. Wells tapping strongly reducing groundwater had depths to water greater than $60 \mathrm{ft}$ and measured water levels of $15 \mathrm{ft}$ or more above the open interval of the well.

In summary, factors associated with the occurrence of both naturally occurring and human-induced contaminants are listed in the table on the next page. Because most homeowners know if their well water has a high iron content, iron concentration is used in this table as a signal that other contaminants may be present in the water. The aquifer tapped by a well can be discerned by comparing the well location, land-surface elevation, and information on the driller's well $\log$ to elevations of the different aquifers in the county as shown in figure 31 . 


\section{Groundwater Quality in Geauga County, Ohio-Status, 2009, and Changes During 1978-2009}

\begin{tabular}{|c|c|c|}
\hline Source & Constituent & Factors associated with contaminant occurrence \\
\hline \multirow{4}{*}{ 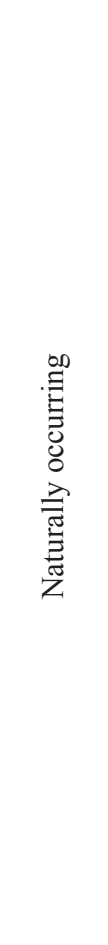 } & $\begin{array}{l}\text { Arsenic at concentrations } \\
\text { exceeding the human- } \\
\text { health benchmark } \\
(10 \mu \mathrm{g} / \mathrm{L})\end{array}$ & $\begin{array}{l}\text { Wells producing strongly reducing water (signaled by iron concentrations greater than } \\
100 \mu \mathrm{g} / \mathrm{L} \text { - especially if the concentration is high enough to affect taste and stain } \\
\text { fixtures or laundry). At particular risk are wells having more than about } 30 \mathrm{ft} \text { of clay } \\
\text { above the uncased portion of the well, or wells tapping the Pottsville Formation in ar- } \\
\text { eas where sandstone is overlain by shale. Berea Sandstone wells with depth to water } \\
\text { of more than } 60 \mathrm{ft} \text { may also be at risk. }\end{array}$ \\
\hline & $\begin{array}{l}\text { Manganese at concentrations } \\
\text { exceeding the human- } \\
\text { health benchmark } \\
(300 \mu \mathrm{g} / \mathrm{L})\end{array}$ & $\begin{array}{l}\text { Wells tapping the Pottsville Formation in Burton, Middlefield, and Parkman Townships } \\
\text { (where manganese content of aquifer materials and [or] overlying sediments appears } \\
\text { to be higher than elsewhere in the county) and that produce strongly reducing water. } \\
\text { (Strongly reducing water is signaled by iron concentrations greater than } 100 \mu \mathrm{g} / \mathrm{L}- \\
\text { especially if the concentration is high enough to affect taste and stain fixtures or } \\
\text { laundry). Wells producing water with a pH less than } 7 \text { may be particularly at risk. }\end{array}$ \\
\hline & $\begin{array}{l}\text { Sodium at concentrations ex- } \\
\text { ceeding the human-health } \\
\text { benchmark }(20 \mathrm{mg} / \mathrm{L})\end{array}$ & Wells tapping the Berea Sandstone or Cuyahoga Group. \\
\hline & $\begin{array}{l}\text { Total sulfide } \\
\text { (Hydrogen sulfide gas } \\
\text { and [or] precipitating iron } \\
\text { sulfide minerals) }\end{array}$ & $\begin{array}{l}\text { Wells producing strongly reducing water (signaled by iron concentrations greater than } \\
100 \mu \mathrm{g} / \mathrm{L} \text { - especially if the concentration is high enough to affect taste and stain fix- } \\
\text { tures or laundry). Sulfide concentrations increase at lower elevations, with concentra- } \\
\text { tions greater than } 0.1 \mathrm{mg} / \mathrm{L} \text { occurring in some wells that have a well bottom elevation } \\
\text { below } 1,060 \mathrm{ft} \text { and tap the glacial deposits, Cuyahoga Group, or Berea Sandstone. }\end{array}$ \\
\hline
\end{tabular}

Methane

Wells tapping the Berea Sandstone or Cuyahoga Group. Signs of methane include spurting faucets, cloudy water, and bubbles in water. Limited evidence suggests that a well that has experienced a significant decrease in water level since it was drilled and (or) a well that intersects a structurally high area at the top of the Berea Sandstone (shown as an area of closed contours and high elevation in figure 35) may be more likely to contain methane than a well that does not have these characteristics.

Total coliform bacteria at concentrations exceeding the human-health benchmark of 4 colonies per 100 milliliters of water

Chloride

(although concentrations exceeding the SMCL of $250 \mathrm{mg} / \mathrm{L}$ are unlikely)

Nitrate

(although concentrations exceeding the humanhealth benchmark of 10 $\mathrm{mg} / \mathrm{L}$ are unlikely)
Wells with a total depth of less than $140 \mathrm{ft}$ below land surface. Wells with a total depth of less than $70 \mathrm{ft}$ below land surface and (or) with a shallow cased interval are particularly at risk. Also at risk are wells that produce water with visible turbidity.

Wells with shallow depth to groundwater (less than $50 \mathrm{ft}$ below land surface, with greater risk at depths of less than $30 \mathrm{ft}$ below land surface), particularly if the well is near a road and (or) in an area with upgradient agricultural and developed land cover.

The main criterion for the presence of nitrate is that the well taps oxic or nitrate-reducing water in the Pottsville Formation or Berea Sandstone (characterized by low iron concentrations [less than $100 \mu \mathrm{g} / \mathrm{L}$ ]). Nitrate concentrations greater than $1 \mathrm{mg} / \mathrm{L} \mathrm{oc}-$ cur almost exclusively in water from wells with bottom elevations higher than 1,075 $\mathrm{ft}$ that tap the Pottsville Formation. (These wells also have casing that extends less than $75 \mathrm{ft}$ below land surface.) Limited evidence suggests that wells with upgradient agricultural or developed land are likely to contain somewhat higher concentrations of nitrate than wells with upgradient forested land. 


\section{References Cited}

Agency for Toxic Substances and Disease Registry, 2003, Petitioned health consultation - Cady Road, North Royalton, Cuyahoga County, Ohio: Division of Health Assessment and Consultation, accessed February 28, 2013, at http://www.atsdr.cdc.gov/hac/pha/index.asp.

Agency for Toxic Substances and Disease Registry, 2008, Public health statement, manganese: U.S. Department of Health and Human Services, Public Health Service, September 2008, accessed Nov 12, 2008, at http://www.atsdr. cdc.gov/toxprofiles/tp151-c1-b.pdf.

Ator, S.W., and Denis, J.M., 1997, Relation of nitrogen and phosphorus in ground water to land use in four subunits of the Potomac River Basin: U.S. Geological Survey WaterResources Investigations Report 96-4268, 26 p.

Bair, E.S., Freeman, D.C., and Senko, J.M., 2010, Expert panel technical report-Subsurface gas invasion, Bainbridge Township, Geauga County, Ohio: Ohio Department of Natural Resources, accessed July 15, 2011, at http:// www.dnr.state.oh.us/bainbridge/tabid/20484/Default.aspx.

Baker, Jack, 1964, Geology and ground-water resources of Geauga County, Ohio: Unpublished manuscript on file in Columbus, Ohio, office of the U.S. Geological Survey, $108 \mathrm{p}$.

Baldassare, F.J., and Laughrey, C.D., 1997, Identifying the sources of stray methane by using geochemical and isotopic fingerprinting: Environmental Geosciences, v. 4, no. 2, p. $8-94$.

Bolas, M., and Mohr, E., 1995, Interoffice memorandumManganese investigation, Village of Middlefield, Middlefield Township, Geauga County: Unpublished document on file in the Twinsburg, Ohio, office of the Ohio Environmental Protection Agency, Division of Emergency and Remedial Response, 9 p.

Burns, D.A., Fenn, M.E., Baron, J.S., Lynch, J.A., and Cosby, B.J., 2011, National Acid Precipitation Assessment Program report to Congress 2011 - An integrated assessment: National Acid Precipitation Assessment Program, 114 p., accessed December 4, 2014, at http://ny.water.usgs. gov/projects/NAPAP/.

Button, D.T., 2003, Predicting nitrate and chloride in shallow ground water in a glacial setting using a geographic information system (GIS) and multivariate logistic regression: Columbus, Ohio, The Ohio State University, Master's thesis, $96 \mathrm{p}$.
Breen, K.J., Revesz, K., Baldassare, F.J., and McAuley, S.D., 2007, Natural gases in ground water near Tioga Junction, Tioga County, north-central Pennsylvania-Occurrence and use of isotopes to determine origins, 2005: U.S. Geological Survey Scientific Investigations Report 2007-5085, 65 p.

Chafin, D.T., Swanson, D.M., and Grey, D.W., 1996, Methaneconcentration and methane-isotope data for ground water and soil gas in the Animas River Valley, Colorado and New Mexico, 1990-91: U.S. Geological Survey Water-Resources Investigation Report 93-4007, 49 p.

Code of Federal Regulations, 1987, Title 40, Protection of the environment, Part 141.43-National primary drinking water regulations, Subpart E-Special regulations, including monitoring regulations and prohibition on lead use: Accessed March 20, 2012, at http://ecfr.gpoaccess.gov.

Code of Federal Regulations, 1993, Title 40, Protection of the environment, Part 503 - Standards for disposal of sewage sludge: Accessed August 18, 2010, at http://ecfr.gpoaccess. gov.

DeSimone, L.A., Hamilton, P.A., and Gilliom, R.J., 2009, The quality of our Nation's waters - Quality of water from domestic wells in principal aquifers of the United States, 1991-2004 - Overview of major findings: U.S. Geological Survey Circular 1332, $48 \mathrm{p}$.

Driscoll, F.G., 1986, Groundwater and wells (2d ed.): St. Paul, Minn., Johnson Division, 1,089 p.

Eberts, S.M., Bair, E.S., and de Roche, J.T., 1990, Geohydrology, ground-water quality, and simulated ground-water flow, Geauga County, Ohio: Water-Resources Investigations Report 90-4026, 117 p. [Also available at http://pubs. er.usgs.gov/publication/wri904026.]

Edwards, V.A., Velasco, C.P., and Edwards, K.J., Jr., 2011, Sulfur compounds causing odor and corrosion: Alken-Murray Corp., Web page, accessed May 15, 2011, at http://www. alken-murray.com/H2SREM3.HTM.

Eltschlager, K.K., Hawkins, J.W., Ehler, W.C., and Baldassare, F., 2001, Technical measures for the investigation and mitigation of fugitive methane hazards in areas of coal mining: Office of Surface Mining Reclamation and Enforcement, Appalachian Regional Coordinating Center, $124 \mathrm{p}$.

Fleeger, G.M., Goode, D.J., Buckwalter, T.F., and Risser, D.W., 1999, Hydrologic effects of the Pymatuning earthquake of September 25, 1998, in northwestern Pennsylvania: U.S. Geological Survey Water Resources Investigations Report 99-4170, 8 p. [Also available at http://pa.water.usgs. gov/reports/wrir_99-4170.pdf.] 


\section{Groundwater Quality in Geauga County, Ohio-Status, 2009, and Changes During 1978-2009}

Francy, D.S., Bushon, R.N., Stopar, J., Luzano, E.J., and Fout, G.S., 2004, Environmental factors and chemical and microbiological water-quality constituents related to the presence of enteric viruses and ground water from small public water supplies in southeastern Michigan: U.S. Geological Survey Scientific Investigations Report 2004-5219, 54 p.

Francy, D.S., and Shaffer, K.H., 2008, Quality-assurance plan for water-quality activities in the USGS Ohio Water Science Center: U.S. Geological Survey Open-File Report 2008-1250, 73 p.

Fry, J.A., Coan, M.J., Homer, C.G., Meyer, D.K., and Wickham, J.D., 2009, Completion of the National Land Cover Database (NLCD) 1992-2001 Land Cover Change Retrofit product: U.S. Geological Survey Open-File Report 2008-1379, 18 p. [Also available at http://pubs.usgs.gov/ of/2008/1379/.]

Geauga County Health District, 2010a, Private water wells: Health District Web page, accessed April 21, 2011, at http:// www.geaugacountyhealth.org/water.html.

Geauga County Health District, 2010b, Environmental health-Household sewage treatment systems: Health District Web page, accessed August 20, 2010, at http:/Www. geaugacountyhealth.org/sewage.html.

Gilliom, R.J, Barbash, J.E., Crawford, C.G., Hamilton, P.A., Martin, J.D., Nakagaki, N., Nowell, L.H., Scott, J.C., Stackelberg, P.E., Thelin, G.P., and Wolock, D.M., 2006, The quality of our Nation's waters-Pesticides in the Nation's streams and ground water, 1992-2001: U.S. Geological Survey Circular 1291, 172 p.

Gray, John, 1981, Structure on the Berea Sandstone in eastern Ohio: Ohio Department of Natural Resources, Division of Geological Survey, Open-File Map 132.

Hathaway, R.M., and Eberle, Michael, 1981, Water use in Ohio, 1975: U.S. Geological Survey Water-Resources Investigations Report 81-17, 43 p.

Heisig, P.M., and Scott, T.-M., 2013, Methane occurrence in groundwater of south-central New York State, 2012 Summary of findings: U.S. Geological Survey Fact Sheet 2013-3118, 2 p.

Helsel, D.R., 2005, Nondetects and data analysis-Statistics for censored environmental data: Hoboken, N.J., John Wiley \& Sons, 250 p.

Helsel, D.R., and Hirsch, R.M., 2002, Statistical methods in water resources: U.S. Geological Survey Techniques of Water-Resources Investigations, book 4, chap. A3, 522 p., available at http://pubs.usgs.gov/twri/twri4a3/.

Hem, J.D., 1989, Study and interpretation of the chemical characteristics of natural water $(3 \mathrm{~d}$ ed.): U.S. Geological Survey Water-Supply Paper 2254, 263 p.
Homer, C., Dewitz, J., Fry, J., Coan, M., Hossain, N., Larson, C., Herold, N., McKerrow, A., VanDriel, J.N., and Wickham, J., 2007, Completion of the 2001 National Land Cover Database for the Conterminous United States: Photogrammetric Engineering and Remote Sensing, v. 73, no. 4, p. 337-341, accessed July 6, 2009, at http://www.asprs.org/a/ publications/pers/2007journal/april/; database also accessed July 6, 2009, at http://www.mrlc.gov/nlcd01_data.php.

Hoover, K.V., 1960, Devonian-Mississippian shale sequence in Ohio: Ohio Department of Natural Resources, Division of Geological Survey Information Circular 27, 154 p., 3 pls.

Jagucki, M.L., and Darner, R.A., 2001, Ground-water quality in Geauga County, Ohio-Review of previous studies, status in 1999, and comparison of 1986 and 1999 data: U.S. Geological Survey Water-Resources Investigations Report 01-4160, 61 p. [Also available at http://oh.water.usgs.gov/ reports/wrir/wrir01-4160.pdf.]

Jagucki, M.L., and Lesney, L.L., 1995, Ground-water levels and directions of flow in Geauga County, Ohio, September 1994, and changes in ground-water levels, 1986-94: U.S. Geological Survey Water Resources Investigation Report 95-4194, 26 p. [Also available at http://pubs.er.usgs.gov/ publication/wri954194.]

Janssens, Adriaan, and deWitt, Wallace, Jr., 1976, Potential natural gas resources in the Devonian shales in Ohio: Ohio Department of Natural Resources, Division of Geological Survey, Geological Note 3, 12 p., 1 pl.

John, D.E., Rose, J.B., and Kamarainen, Amy, 2004, Survival of fecal indicator bacteria, bacteriophage and protozoa in Florida's surface and ground waters-Potential implications for aquifer storage and recovery: Final Report of the Fate of Microorganisms in Aquifers Study, accessed March 4, 2014, at http:/www.evergladesplan.org/pm/projects/project_docs/ pdp_asr_combined/052808_asr_report/052808_asr_ch7 asr_fate_of_micros_study.pdf.

Jurgens, B.C., McMahon, P.B., Chapelle, F.H., and Eberts, S.M., 2009, An Excel ${ }^{\circledR}$ workbook for identifying redox processes in ground water: U.S. Geological Survey Open-File Report 2009-1004, 8 p.

Katz, B.G., Eberts, S.M., and Kauffman, L.J., 2011, Using $\mathrm{Cl} / \mathrm{Br}$ ratios and other indicators to assess potential impacts on groundwater quality from septic systems - A review and examples from principal aquifers in the United States: Journal of Hydrology, v. 397, p. 151-166.

Kell, Scott, 2011, State oil and gas agency groundwater investigations and their role in advancing regulatory reforms - A two-state review, Ohio and Texas: Ground Water Protection Council, 119 p. plus appendixes, accessed February 8, 2012, at http://www.gwpc.org/home/GWPC_Home.dwt. 
Kenny, J.F., Barber, N.L., Hutson, S.S., Linsey, K.S., Lovelace, J.K., and Maupin, M.A., 2009, Estimated use of water in the United States in 2005: U.S. Geological Survey Circular 1344, 52 p.

Koziol, Joseph, 2010, Well contamination coming from roadsalt: Chagrin Valley Times, March 3, 2010.

Kunze, A.E., and Sroka, B.N., Effects of highway deicing chemicals on shallow unconsolidated aquifers in OhioFinal report: U.S. Geological Survey Scientific Investigations Report 2004-5150, 187 p.

Landon, M.K., Jurgens, B.C., Katz, B.G., Eberts, S.M., Burow, K.R., and Crandall, C.A., 2009, Depth-dependent sampling to identify short-circuit pathways to public-supply wells in multiple aquifer settings in the United States: Hydrogeology Journal, v. 18, no. 3, p. 577-593, accessed March 6, 2013, at http://oh.water.usgs.gov/tanc/pubs/landon_hydrogeologyjournal_Oct_2009.pdf.

Mancl, Karen; Johnson, Jay; and Veenhuizen, Michael, 1995, Septage management in Ohio: Ohio State University Agricultural Extension Bulletin 854 [variously paged], accessed August 20, 2010, at http://ohioline.osu.edu/b854/index.html.

Mathes, M.V., and White, J.S., 2006, Methane in West Virginia ground water: U.S. Geological Survey Fact Sheet 20063011, 2 p.

Michel, R.L., 1989, Tritium deposition in the continental United States, 1953-83: U.S. Geological Survey WaterResources Investigations Report 89-4072, 46 p.

Milne, G.W.A., ed., 1995, CRC handbook of pesticides: Boca Raton, Fla., CRC Press, 402 p.

Minnesota Department of Health, 2011, Methane in well water: Web page, accessed March 20, 2013, at http:/www. health.state.mn.us/divs/eh/wells/waterquality/methane.html.

Mix, Daniel, 2009 (2013 rev.), Point of listing/sale household sewage evaluation program - An evaluation of its effectiveness and the effectiveness of onsite wastewater technologies in Geauga County, Ohio: Geauga County Health District, $59 \mathrm{p}$.

National Ground Water Association, 2013, Hydrogen sulfide: Web page, accessed March 20, 2013, at http://www. wellowner.org/water-quality/hydrogen-sulfide/.

New Hampshire Department of Environmental Services, 2006, Arsenic in drinking water: Environmental Fact Sheet WDWSEB-3-2, 6 p., accessed February 10, 2010, at http://des. nh.gov/organization/commissioner/pip/factsheets/dwgb/ documents/dwgb-3-2.pdf.
New Jersey Department of Health and Senior Services, 1997, Facts - Volatile organic compounds in drinking water: Pamphlet, accessed March 20, 2013, at http:/www.state.nj.us/ health/eoh/hhazweb/vocs.pdf.

New Mexico Environment Department, 2008, Volatile organic compounds: Web page, accessed March 20, 2013 at http:// www.nmenv.state.nm.us/dwb/contaminants/vocs.htm

Nichols, V.E., 1980, Ground-water levels and chemical quality in Geauga County, Ohio, 1978: U.S. Geological Survey Water-Resources Investigation Report 80-28, 17 p.

Oblinger Childress, C.J., Foreman, W.T., Conner, B.F., and Maloney, T.J., 1999, New reporting procedures based on long-term method detection levels and some considerations of interpretations of water-quality data provided by the U.S. Geological Survey National Water Quality Laboratory: U.S. Geological Survey Open-File Report 99-193, 19 p.

Ohio Department of Health, 2011a, Private water systems: Ohio Administrative Code, chap. 3701-28, secs. 3 and 4, accessed March 20, 2013 at http:/codes.ohio.gov/ oac/3701-28.

Ohio Department of Health, 2011b, Total \& fecal coliform bacteria: Bureau of Environmental Health Web document, accessed March 19, 2013, at http://www.odh.ohio.gov/odhprograms/eh/water/PrivateWaterSystems/quality_treatment. aspx.

Ohio Department of Health, 2012, Microbiological standards for private water systems in Ohio: Bureau of Environmental Health Web document, accessed March 19, 2013, at http:// www.odh.ohio.gov/odhprograms/eh/water/PrivateWaterSystems/quality_treatment.aspx.

Ohio Department of Natural Resources, 1977-2012, Monthly water inventory report for Ohio: Annual summary published in December issue each year, accessed March 13, 2014, at http://www.dnr.state.oh.us/tabid/4191/default.aspx.

Ohio Department of Natural Resources, 2008a, Oil and gas well location database - Geauga County, theme ID 1338, downloaded December 16, 2008, from http://www.dnr.state. oh.us/dnnapps/gims/response.asp?county=GEAUGA\&categ ory $=$ Geologic $\% 2$ FSoils.

Ohio Department of Natural Resources, 2008b, Report on the investigation of the natural gas invasion of aquifers in Bainbridge Township of Geauga County, Ohio: Division of Mineral Resources Management, 84 p. [plus appendixes], accessed August 14, 2010, at http://www.dnr.state.oh.us/ Portals/11/bainbridge/report.pdf.

Ohio Department of Natural Resources, 2010a, Summary of Ohio oil and gas activities - 2009: Division of Mineral Resources Management, Columbus, Ohio, 20 p. 


\section{Groundwater Quality in Geauga County, Ohio-Status, 2009, and Changes During 1978-2009}

Ohio Department of Natural Resources, 2010b, Water withdrawal registration program database: August 2010 version.

Ohio Environmental Protection Agency, 1995, Geauga Industries, Geauga County, Ohio, Integrated Assessment: Unpublished document on file at the Twinsburg, Ohio, office of the Ohio Environmental Protection Agency, Division of Emergency and Remedial Response, 44 p.

Ohio Environmental Protection Agency, 2006a, Sewage sludge disposal in Ohio for 2006: Web document, accessed March 23, 2010, at http://www.epa.ohio.gov/portals/35/sludge/ SewageSludgeDisposalInOH2006.pdf.

Ohio Environmental Protection Agency, 2006b, Arsenic fact sheet for public water system customers: Columbus, Ohio, Office of the Ohio Environmental Protection Agency, Division of Drinking and Ground Waters, 2 p., accessed February 28, 2013, at http:/www.epa.state.oh.us/portals/28/documents/pws/ArsenicFactsheet.pdf.

Ohio Environmental Protection Agency, 2010a, Map of fields approved for biosolids application: Division of Surface Water, Biosolids Program, accessed March 23, 2010, at http://wwwapp.epa.ohio.gov/dsw/gis/sludge/index.php.

Ohio Environmental Protection Agency, 2010b, Ground water impacts database: Unpublished data on file at the Columbus, Ohio, Office of the Division of Drinking and Ground Waters.

Ohio Environmental Protection Agency, 2010c, Drinking water source assessment reports and maps: Web page, accessed June 2010 at http:/www.epa.state.oh.us/ddagw/ swap-assessments.aspx.

Ohio Environmental Protection Agency, 2010d, Ambient groundwater monitoring program database: Division of Drinking and Ground Waters, April 2010 version.

Ohio Environmental Protection Agency, 2010e, Safe Drinking Water Information System (SDWIS) database: Division of Drinking and Ground Waters, August 2010 version.

Ohio Environmental Protection Agency, 2012a, Database of investigated sites: Unpublished data on file at the Columbus, Ohio, office of the Division of Emergency and Remedial Response.

Ohio Environmental Protection Agency, 2012b, Ohio’s 2012 integrated water quality monitoring and assessment report, section M-Ground water quality: Division of Drinking and Ground Waters, p. M1-M33, accessed March 13, 2014. at http://www.epa.state.oh.us/ddagw/gwqcp. aspx\#LiveTabsContent115411.
Ohio Environmental Protection Agency and Ohio Department of Health, 2004, Domestic septage disposal in Ohio: Fact sheet, 4 p., accessed March 23, 2010, at http://www. epa.ohio.gov/portals/35/documents/Septage $\% 20$ fact $\% 20$ sheet $\% 20$ final.pdf.

Panno, S.V., Hackley, K.C., Hwang, H.H., Greenberg, S., Krapac, I.G., Landsberger, S., and O’Kelly, D.J., 2005, Database for the characterization and identification of the sources of sodium and chloride in natural waters of Illinois: Illinois State Geological Survey Open File Series 2005-1, $15 \mathrm{p}$.

Panno, S.V., Hackley, K.C., Hwang, H.H., Greenberg, S., Krapac, I.G., Landsberger, S., and O'Kelly, D.J., 2006, Characterization and identification of $\mathrm{Na}-\mathrm{Cl}$ sources in ground water: Ground Water, v. 44, no. 2, p. 176-187.

PRISM Climate Group, 2006, United States average annual precipitation, 1971-2000: Oregon State University, http:// prism.oregonstate.edu, created June 12, 2006.

Sandstrom, M.W., Stroppel, M.E., Foreman, W.T., and Schroeder, M.P., 2001, Methods of analysis by the U.S. Geological Survey National Water Quality Laboratory-Determination of moderate-use pesticides and selected degradates in water by C-18 solid-phase extraction and gas chromatography/mass spectrometry: U.S. Geological Survey WaterResources Investigations Report 2001-4098, 70 p.

Schwietering, J.F., 1979, Devonian shales of Ohio and their eastern and southern equivalents: U.S. Department of Energy, report METC/CR-79/2, 68 p.

Slattery, Linda; Slattery, Michael; Kenah, Chris; and Eggert, Michael, 2006, Volatile organic compounds in Ohio's ground water: Geological Society of America North-Central Meeting, accessed March 23, 2010, at http://www.epa.state. oh.us/portals/28/documents/gwqcp/presentation-GSAVOCs\%20in\%20GW.pdf.

Smedley, P.L., and Kinniburg, D.G., 2002, A review of the source, behaviour and distribution of arsenic in natural waters: Applied Geochemistry, v. 17, p. 517-568.

Strausberg, S.I., 1983, Turbidity interferes with accuracy in heavy metal concentrations: Industrial Wastes, v. 29, no. 2, p. 16-21.

Tele Atlas North America, Inc., 2008, 2000 U.S. Census Block centroid populations, ESRI data \& maps, 2008 World, Europe, United States, Canada, and Mexico: Redlands, Calif. 
Thomas, M.A., 2007, The association of arsenic with redox conditions, depth, and ground-water age in the glacial aquifer system of the northern United States: U.S. Geological Survey Scientific Investigations Report 2007-5036, 26 p.

Tomastik, Tom, 2010, Ohio's regulations on natural gas development and disposal of oilfield wastes: Online slide presentation, accessed April 6, 2010, at http://www.columbianahealth.org/pdf/ohio_regulations_natural_gas.pdf.

U.S. Census Bureau, 2009, TIGER/Line Shapefile, 2009, 2000 county, Geauga County OH, Census 2000 Block Countybased: Census Bureau dataset, accessed July 7, 2010, at http://www.census.gov/geo/www/tiger.

U.S. Census Bureau, 2010, 2009 Population estimated, incorporated places and minor civil divisions: Census Bureau dataset, accessed March 18, 2013, at http://www.census. gov/popest/data/cities/totals/2009/SUB-EST2009-states. html.

U.S. Census Bureau, 2014, Population-total and selected characteristics, Geauga, Ohio: Census Bureau dataset, accessed March 13, 2014, at http://censtats.census.gov/usa/usa.shtml.

U.S. Department of Health and Human Services, 2004, Health consultation, groundwater contamination issues at Geauga Industries in Middlefield, Geauga County, Ohio: 23 p.

U.S. Environmental Protection Agency, 1992, Water quality standards; establishment of numeric criteria for priority toxic pollutants, States' compliance-Final rule (12/22/92) (“Toxics Rule"): Federal Register, v. 57, no. 246, p. 6084860923.

U.S. Environmental Protection Agency, 2001, The incorporation of water treatment effects on pesticide removal and transformations in Food Quality Protection Act (FQPA) drinking water assessments: Office of Pesticide Programs, accessed March18, 2012, at http://epa.gov/pesticides/trac/ science/water_treatment.pdf.

U.S. Environmental Protection Agency, 2003, Drinking water advisory - Consumer acceptability advice and health effects analysis on sodium: Washington D.C., EPA 822-R-03-006, $29 \mathrm{p}$.

U.S. Environmental Protection Agency, 2006, Drinking water standards and health advisories: Washington D.C., EPA 822R-06-013, 12 p.

U.S. Environmental Protection Agency, 2009, National primary and secondary drinking water regulations: Washington D.C., EPA 816-F-09-004, 6 p.
U.S. Environmental Protection Agency, 2012, Water-Sewage sludge (biosolids) - Frequently asked questions: Web page, accessed February 16, 2012, at http://water.epa.gov/ polwaste/wastewater/treatment/biosolids/genqa.cfm.

U.S. Environmental Protection Agency, 2013, Ethylene dibromide (dibromoethane): Web page, accessed June 6, 2013, at http://www.epa.gov/ttnatw01/hlthef/ethyl-di.html.

U.S. Geological Survey, 1981, Water resources data, Ohio, water year 1980: U.S. Geological Survey Water-Data Report OH-80-2, p. 217-244.

U.S. Geological Survey, 1997-present, National field manual for the collection of water-quality data: U.S. Geological Survey Techniques of Water-Resources Investigations, book 9, chaps. A1-A9 [variously paged]. [Chapters were published and revised from 1997 to present; updates and revisions are ongoing and can be viewed at http://water.usgs. gov/owq/Fieldprocedures.html.]

U.S. Geological Survey, 2010, Branch of Quality Systems: Web page, accessed May 15, 2012, at http://bqs.usgs.gov.

U.S. Geological Survey, 2014, Acid rain: U.S. Geological Survey Water Science School Web page, accessed November 26, 2014, at http://water.usgs.gov/edu/acidrain.html.

Van Stempvoort, D., Maathuis, H., Jaworski, E., Mayer, B., and Rich, K., 2005, Oxidation of fugitive methane in groundwater linked to bacterial sulfate reduction: Ground Water, v. 43, no. 2, p. 187-199.

Vermont Department of Health, 2011, Volatile organic compounds in drinking water: Web page, accessed March 20, 2013, at http://healthvermont.gov/enviro/water/voc_drinking.aspx.

Zaugg, S.D., Sandstrom, M.W., Smith, S.G., and Fehlberg, K.M., 1995, Methods of analysis by the U.S. Geological Survey National Water Quality Laboratory-Determination of pesticides in water by $\mathrm{C}-18$ solid-phase extraction and capillary-column gas chromatography/mass spectrometry with selected-ion monitoring: U.S. Geological Survey Open-File Report 95-181, 49 p.

Zogorski, J.S.; Carter, J.M.; Ivahnenko, Tamara; Lapham, W.W.; Moran, M.J.; Rowe, B.L.; Squillace, P.J.; and Toccalino, P.L., 2006, The quality of our Nations's watersVolatile organic compounds in the Nation's ground water and drinking-water supply wells: U.S. Geological Survey Circular 1292, $101 \mathrm{p}$. 



\section{Appendixes}

Appendix 1. Variation in Water Levels in Selected Long-Term Network Wells Relative to Variation in Annual Precipitation

Appendix 2. Quality Assurance/Quality Control

Appendix 3. Land Cover and Population Upgradient of Each Well

Appendix 4. Water-Quality Data

Appendix 5. Oxidation-Reduction Classification of Samples 


\section{Appendix 1. Variation in Water Levels in Selected Long-Term Network Wells Relative to Variation in Annual Precipitation}

To determine the amount of groundwater-level fluctuation in each network well that is caused by variation in annual precipitation, we used a visual curve-matching procedure whereby the $y$-scale of the hydrograph for each well was adjusted so that annual fluctuations in water level from 1996 through 2012 (plotted on the primary $y$-axis) coincided, as closely as possible, with annual fluctuations in precipitation, plotted on a secondary $y$-axis (fig. 1-1, at end of appendix). Annual precipitation data are from Ohio Department of Natural Resources (1977-2012). Yearly departure from normal ${ }^{1}$ is taken from the December issue, departure from normal for the past 12 months in Northeast Ohio. Thus, when graphed, the departure from normal for a given year is plotted on December 31 of that year.

1 "Normal" precipitation from 1995 through 2001 is based on average annual precipitation for the years 1941-1990. "Normal" precipitation for 2002 through 2011 is based on average annual precipitation for 1951-2000. "Normal" precipitation for 2012 is based on average annual precipitation for 1961-2010.
Since 1994, water-level fluctuations in most network wells have generally mimicked variations in annual precipitation (although there may be a lag time between precipitation and aquifer response). This similarity indicates that inflow to and outflow from the groundwater system are in equilibrium at these well locations. In Geauga County, inflow consists almost exclusively of infiltrating precipitation (Eberts and others, 1990), whereas outflow consists of discharge to springs, streams, lakes, wetlands, pumping wells, and water loss due to evaporation and transpiration by plants. Because the curve-matching procedure is unique to each well, it incorporates differences in the water-level response to annual precipitation that is influenced by depth to groundwater, the aquifer tapped by the well, and permeability of rocks and sediments overlying the aquifer in the vicinity of the well. Once the curve-matching procedure has been done for a well by using data covering a period of a few years, both future groundwater levels and past groundwater levels in that well can be expected to plot near the annual precipitation trendline, as long as the hydrograph scales remain the same and as long as in the inflow and outflow equilibrium conditions that were used for curve-matching remain essentially unchanged.

The curve-matched plots (1996-2012) were used to evaluate historical, intermittent water levels for the 13 wells for which data are available from previous studies (periods of record ranging from 1978, 1980, or 1985 to 1994)

Table 1-1. Comparison of water-level difference, 1986-1994, to approximate magnitude of water-level departure from annual precipitation trendline for wells with historical data (1978-1994) in Geauga County, Ohio.

\begin{tabular}{|c|c|c|c|c|c|}
\hline $\begin{array}{l}\text { Year began } \\
\text { measuring } \\
\text { water levels } \\
\text { at this well }\end{array}$ & $\begin{array}{l}\text { Well } \\
\text { name }\end{array}$ & Aquifer & $\begin{array}{c}\text { Water-level } \\
\text { difference, in feet, } \\
\text { 1986-1994 } \\
\text { (from Jagucki and } \\
\text { Lesney, 1995) }\end{array}$ & $\begin{array}{l}\text { Pre-1994 water } \\
\text { level departs } \\
\text { from annual } \\
\text { precipitation } \\
\text { trendline?' }\end{array}$ & $\begin{array}{l}\text { Approximate } \\
\text { magnitude of } \\
\text { departure, } \\
\text { in feet }\end{array}$ \\
\hline \multirow[t]{3}{*}{1978} & GE-22 & Pottsville Formation & $\left({ }^{3}\right)$ & No & 0.0 \\
\hline & GE-23 & Pottsville Formation & -6.64 & Yes & -6.0 \\
\hline & GE-76 & Glacial deposits & 0.58 & Yes & -2.5 \\
\hline \multirow[t]{4}{*}{1980} & GE-103 & Berea Sandstone & -8.29 & Yes & -12.0 \\
\hline & GE-106 & Cuyahoga Group & -0.63 & Yes & -5.0 \\
\hline & GE-112 & Pottsville Formation & -1.50 & Yes & -4.0 \\
\hline & GE-119 & Pottsville Formation & -3.18 & Yes & -6.0 \\
\hline \multirow[t]{2}{*}{1985} & GE-136 & Cuyahoga Group & -4.73 & Yes & -2.0 \\
\hline & GE-139 & Pottsville Formation & -0.79 & No & 0.0 \\
\hline \multirow[t]{4}{*}{1986} & GE-150 & Pottsville Formation & -0.47 & Yes & -2.0 \\
\hline & GE-163 & Pottsville Formation & -7.19 & Yes & -6.5 \\
\hline & GE-170 & Cuyahoga Group & -0.29 & No & 0.0 \\
\hline & GE-202 & Pottsville Formation & -2.70 & Yes & -2.0 \\
\hline
\end{tabular}

\footnotetext{
${ }^{1}$ Based on fig. 1-1A and B.

${ }^{2}$ Calculated as difference between earliest water-level measurement at a given well and its expected plotting locaton on that date along the annual precipitation trendline (see fig. 1-1A, red arrow labeled as "water-level decline").
}

${ }^{3}$ No water-level measurements were made at this well in 1986. 
(fig. 1-1A and $B$ ). In 10 of the 13 wells, intermittent water levels prior to 1994 plotted above the current equilibrium levels denoted by the precipitation trendline (fig. 1-1A), indicating that groundwater system inflows were greater in the past than they have been since 1994 and (or) outflow volumes were smaller in the past than they have been since 1994. Because it is clear that annual precipitation (inflow) prior to 1994 was not greater than precipitation after 1994 (fig. 1-1A), the water-level declines that occurred prior to 1994 must have been caused by an increase in groundwater outflow. Possible reasons for increased outflow will be discussed in subsequent paragraphs. The magnitude of the water-level decline in each of the 10 wells was approximated as distance, in feet, between the earliest water-level measurement at a well and its expected plotting location on that date along the annual precipitation trendline (denoted by a red arrow in fig. 1-1A). Water-level declines (departures from annual precipitation trendline) ranged from approximately 2 to 12 feet (ft) (table 1-1), and were noted in wells tapping each of the four primary aquifers.

Water-level declines in the county were likely much more widespread than indicated by just the 10 wells documented in figure 1-1A. Table 1-1 and figure 1-2 show the relation of differences in measured water levels between 1986 and 1994 as reported by Jagucki and Lesney (1995) to magnitude of water-level departures from the annual precipitation trendline for the 10 wells in the long-term network with documented declines (denoted by red arrows in fig. 1-1A). These data suggest that measured water-level differences of $1 \mathrm{ft}$ or more between 1986 and 1994 correspond to historic water levels that departed from the annual precipitation trendline or, in other words, showed a water-level decline that was greater than would be expected due to fluctuations in annual precipitation. Thus, of the 88 wells measured by Jagucki and Lesney (1995) in both 1986 and 1994, the 50 wells
(57 percent) with water levels that declined by $1 \mathrm{ft}$ or more likely were influenced by factors other than differences in annual precipitation between the two years. (At the time that Jagucki and Lesney reported their findings [1995], there were insufficient data to distinguish a water-level decline caused by a year of low precipitation from a water-level decline caused by increased water withdrawals.) Jagucki and Lesney (1995) noted that water-level declines between 1986 and 1994 occurred in all four aquifers and that water-level declines of greater than $10 \mathrm{ft}$ were measured primarily in wells tapping the Cuyahoga Group and Berea Sandstone.

The cause for the water-level decline in many wells during the late 1970s and 1980s is not clear. The most likely explanation is that water levels in these wells reflected an ongoing response to the rapid population growth (and the associated increased groundwater withdrawals) that occurred from 1950 to 1970 (fig. 4). In this scenario, water-level declines would have begun before water levels were first measured in 1978. Slowing population growth in the 1980s might have allowed water levels in most wells to stabilize by the 1990s and to reach a new equilibrium between inflow and outflow. A second contributing factor to the observed water-level declines could be the magnitude 5.0 earthquake on January 31, 1986 (epicenter just north of Hambden Township) (fig. 7). This earthquake might have created new bedrock fractures that increased aquifer drainage and discharge, as occurred in nearby Pymatuning, Pennsylvania following a magnitude 5.2 earthquake in 1998 (Fleeger and others, 1999). Evidence for this hypothesis is the fact that the greatest decline was observed in the well closest to the epicenter (well GE-103) and that steep declines occurred in other wells (GE-106, GE-163, GE-202) in the months after the earthquake in 1986 (fig. 1-1A) but before the decrease in precipitation that occurred in 1987 and 1988.

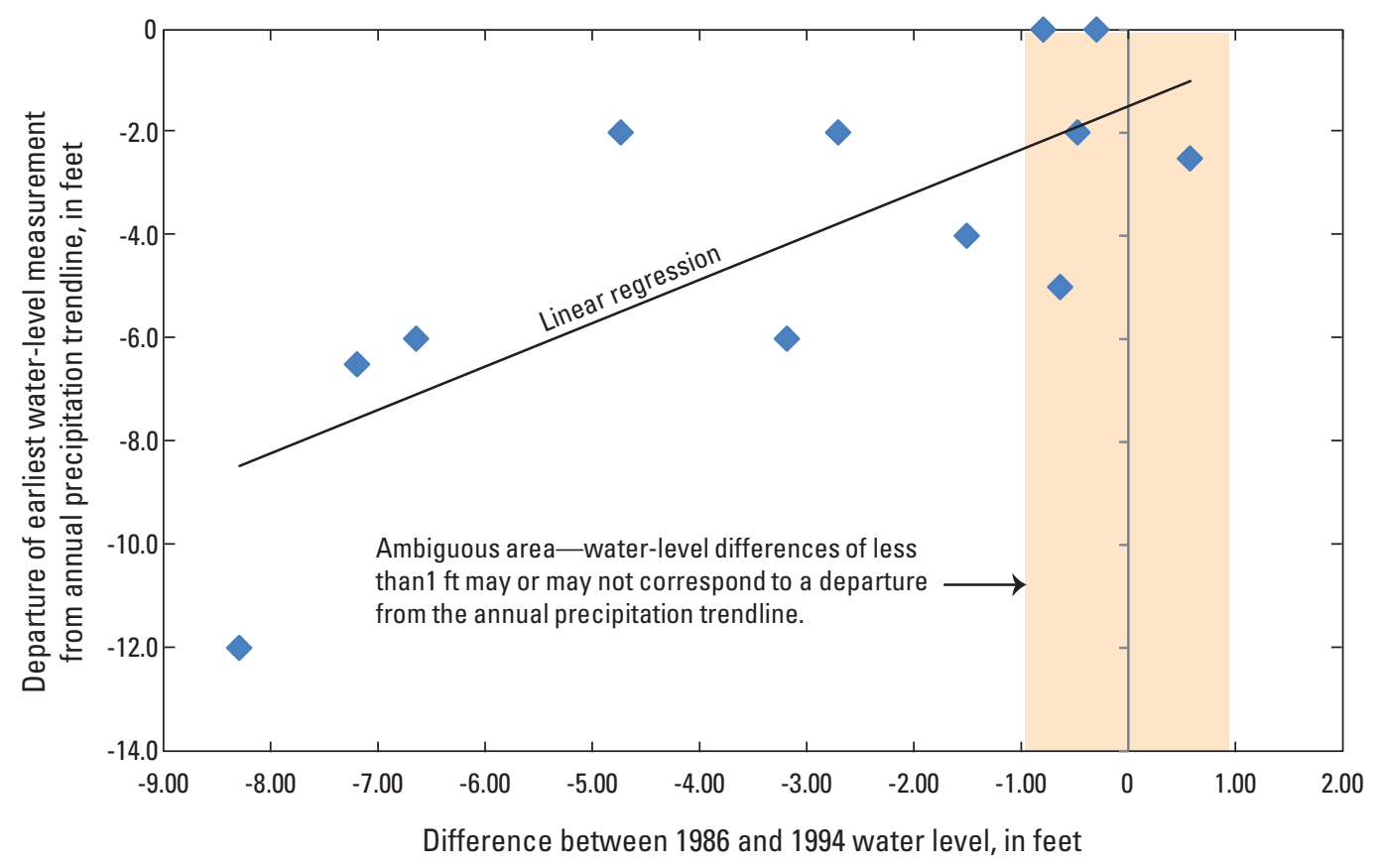

Figure 1-2. Relation of measured difference in water level between 1986 and 1994 to departure of water level from annual precipitation trendline, 1986 or earlier. (Difference between 1986 and 1994 water level is from Jagucki and Lesney [1995, table 5]; departure of earliest waterlevel measurement from annual precipitation trendline is denoted by red arrow, fig 1-1A.) 
A. Wells with water level that departs from precipitation trend line prior to 1994
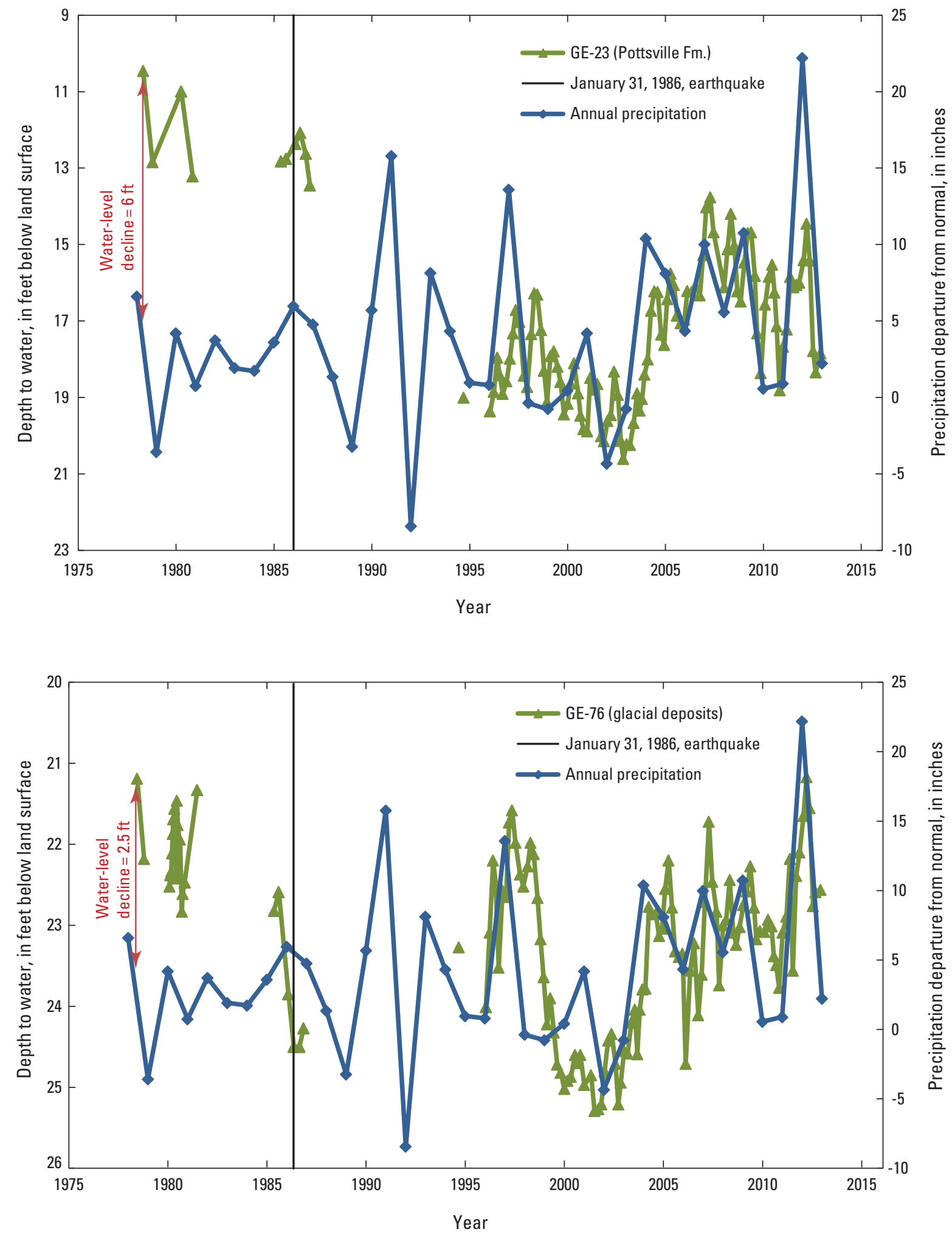

Figure 1-1. Relation of water levels in selected long-term network wells, 1978-2012, to variation in annual precipitation. ( $\mathrm{ft}$, feet; Fm., formation. Annual precipitation data are departure from normal for the climatological Northeast Region of Ohio [Ohio Department of Natural Resources, 1977-2012]. “Normal precipitation” and plotting conventions are described in appendix 1 text.) 
A. Wells with water level that departs from precipitation trend line prior to 1994—Continued
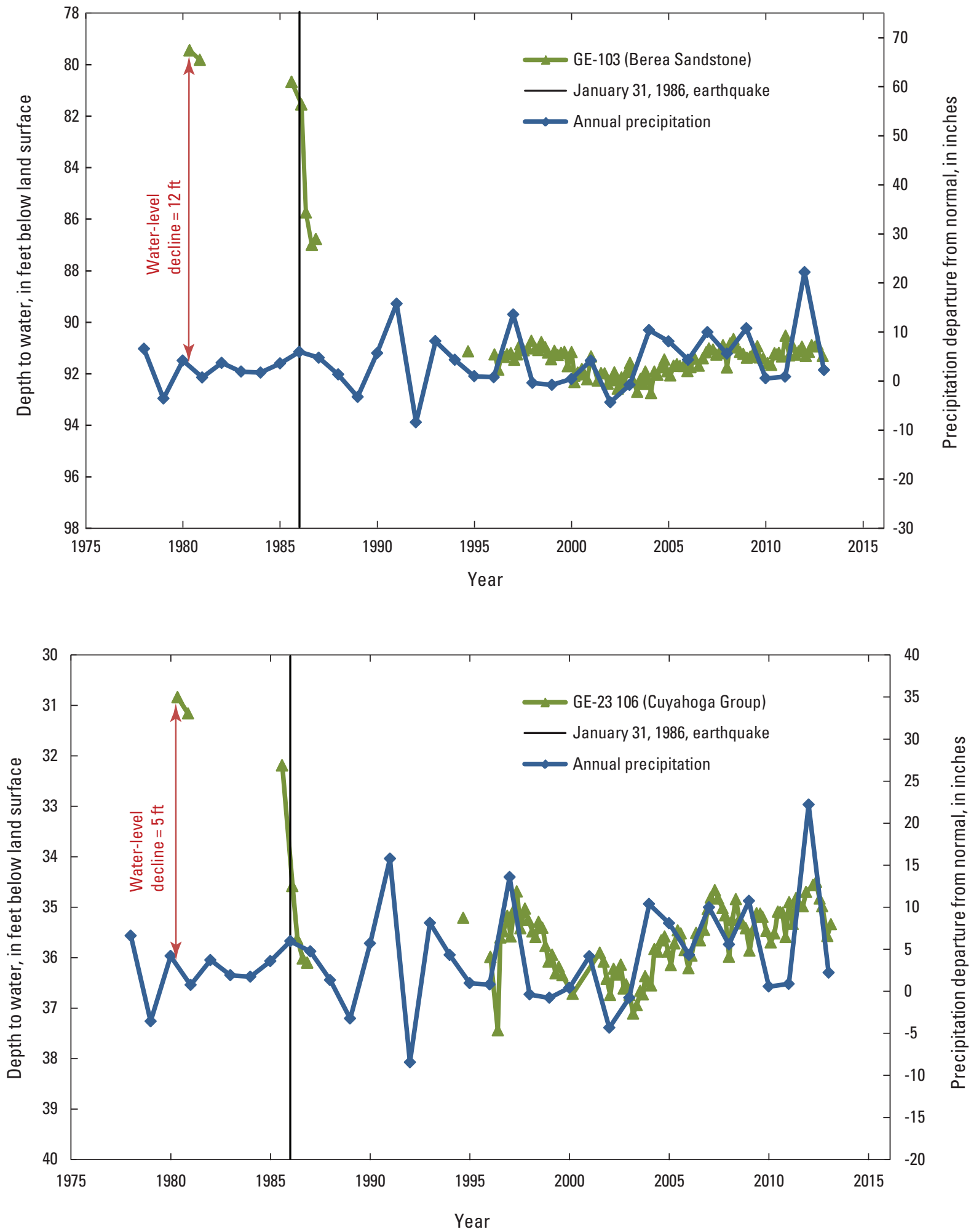

Figure 1-1. Relation of water levels in selected long-term network wells, 1978-2012, to variation in annual precipitation. (ft, feet; Fm., formation. Annual precipitation data are departure from normal for the climatological Northeast Region of Ohio [Ohio Department of Natural Resources, 1977-2012]. "Normal precipitation" and plotting conventions are described in appendix 1 text.)—Continued 
A. Wells with water level that departs from precipitation trend line prior to 1994—Continued
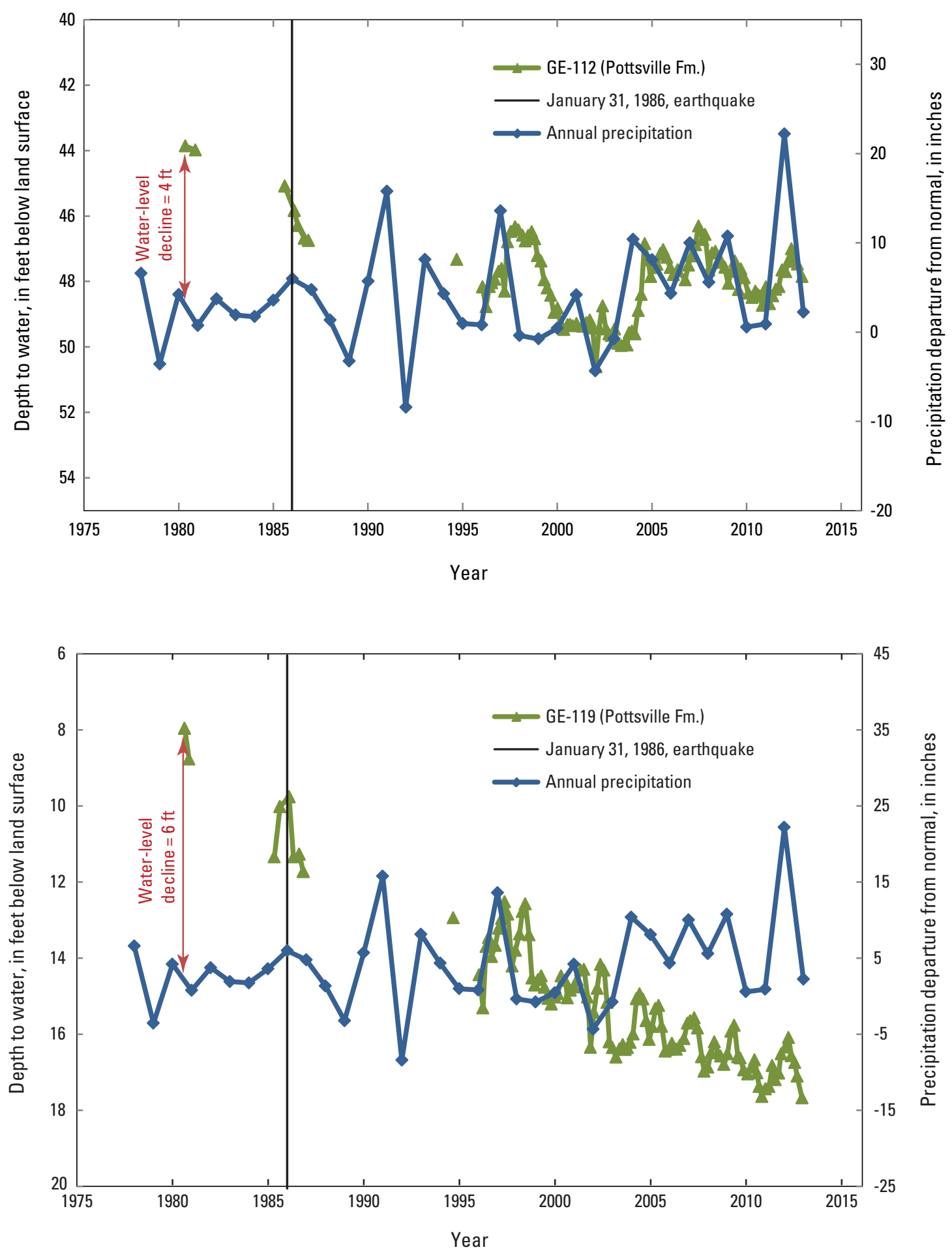

Figure 1-1. Relation of water levels in selected long-term network wells, 1978-2012, to variation in annual precipitation. (ft, feet; Fm., formation. Annual precipitation data are departure from normal for the climatological Northeast Region of Ohio [Ohio Department of Natural Resources, 1977-2012]. “Normal precipitation” and plotting conventions are described in appendix 1 text.) —Continued 
A. Wells with water level that departs from precipitation trend line prior to 1994—Continued
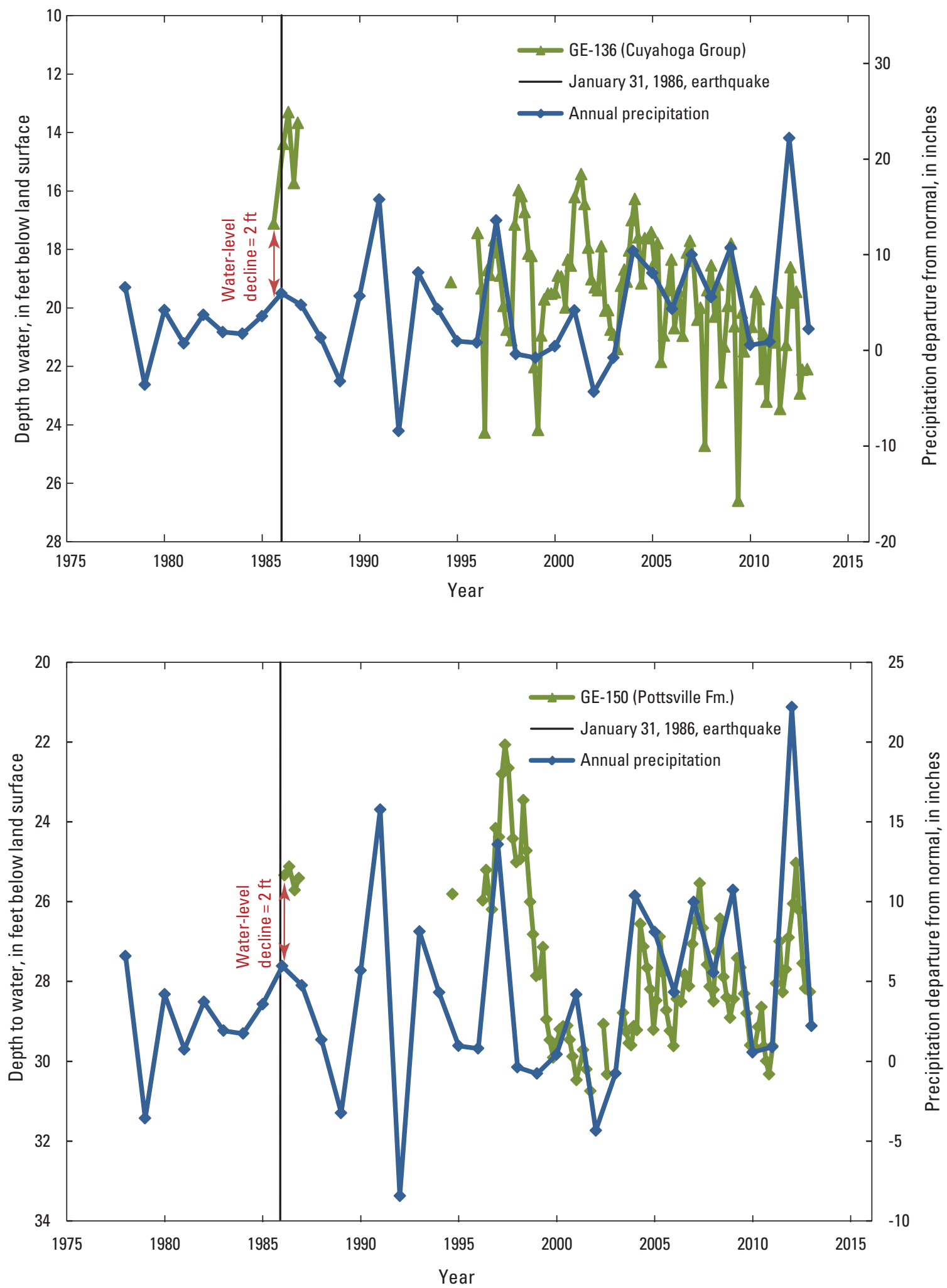

Figure 1-1. Relation of water levels in selected long-term network wells, 1978-2012, to variation in annual precipitation. ( $\mathrm{ft}$, feet; Fm., formation. Annual precipitation data are departure from normal for the climatological Northeast Region of Ohio [Ohio Department of Natural Resources, 1977-2012]. "Normal precipitation" and plotting conventions are described in appendix 1 text.)-Continued 
A. Wells with water level that departs from precipitation trend line prior to 1994-Continued
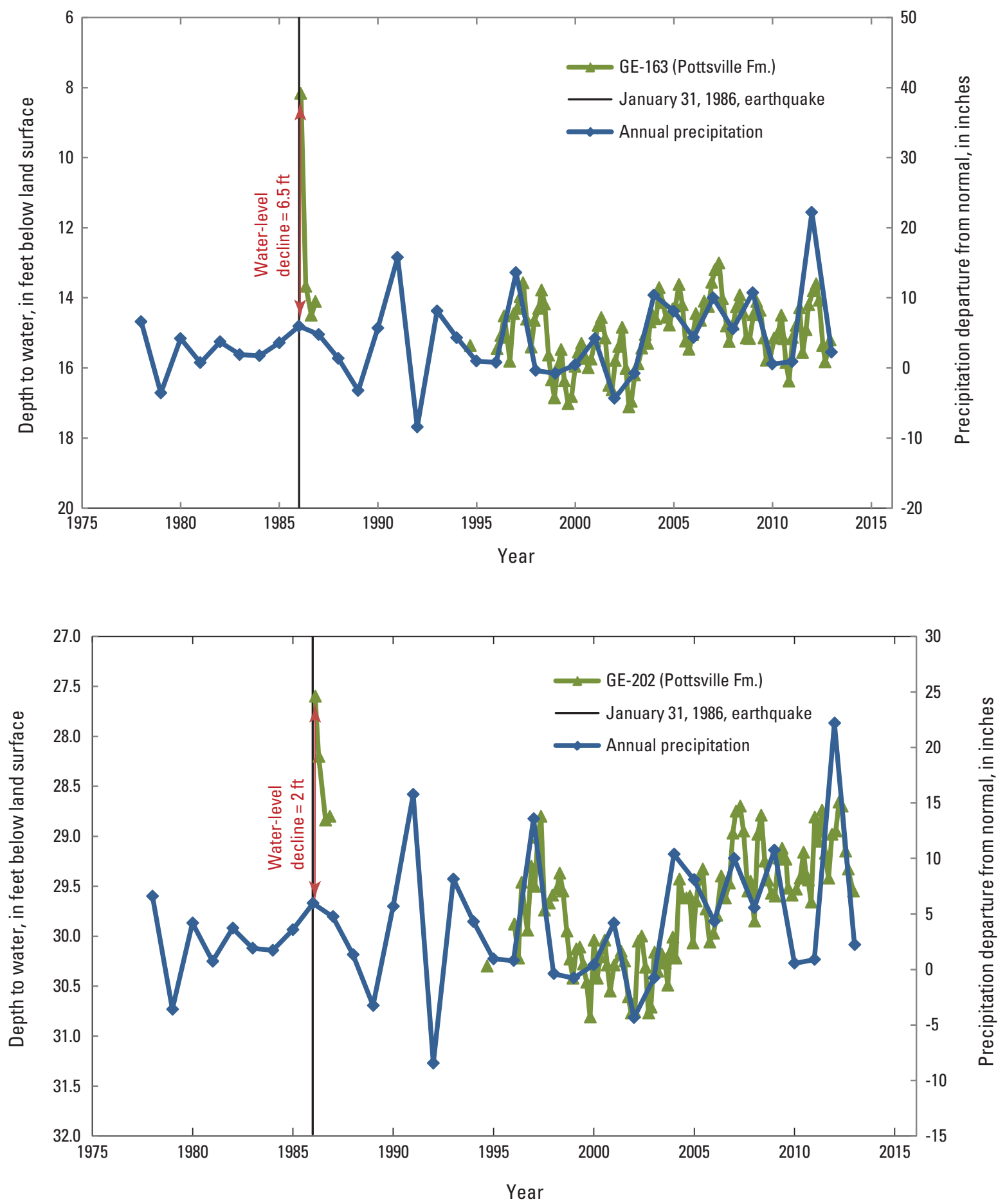

Figure 1-1. Relation of water levels in selected long-term network wells, 1978-2012, to variation in annual precipitation. (ft, feet; Fm., formation. Annual precipitation data are departure from normal for the climatological Northeast Region of Ohio [Ohio Department of Natural Resources, 1977-2012]. “Normal precipitation” and plotting conventions are described in appendix 1 text.) - Continued 
B. Wells showing no departure from precipitation trend line prior to 1994
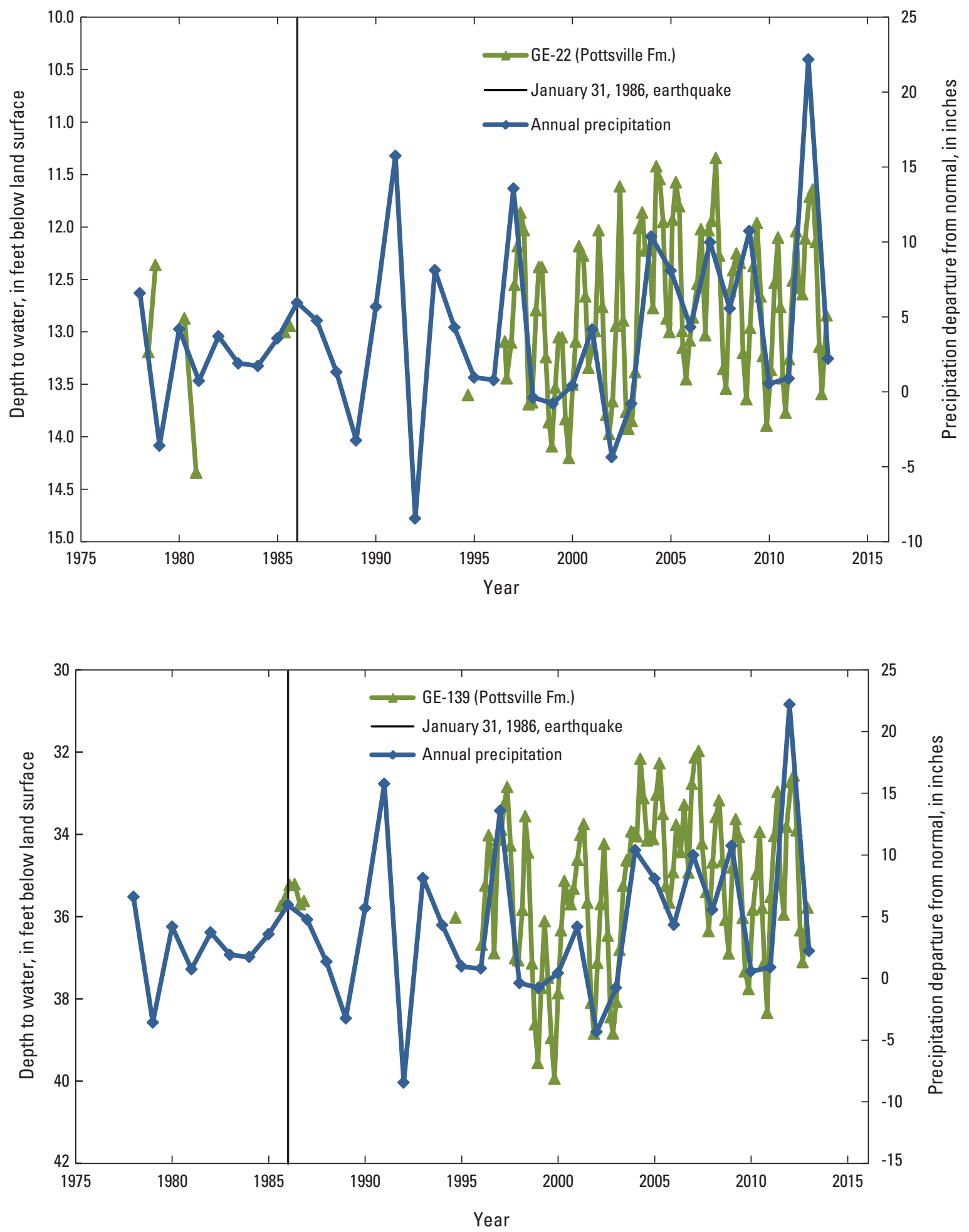

Figure 1-1. Relation of water levels in selected long-term network wells, 1978-2012, to variation in annual precipitation. (ft, feet; Fm., formation. Annual precipitation data are departure from normal for the climatological Northeast Region of Ohio [Ohio Department of Natural Resources, 1977-2012]. "Normal precipitation" and plotting conventions are described in appendix 1 text.) —Continued 
B. Wells showing no departure from precipitation trend line prior to 1994—Continued

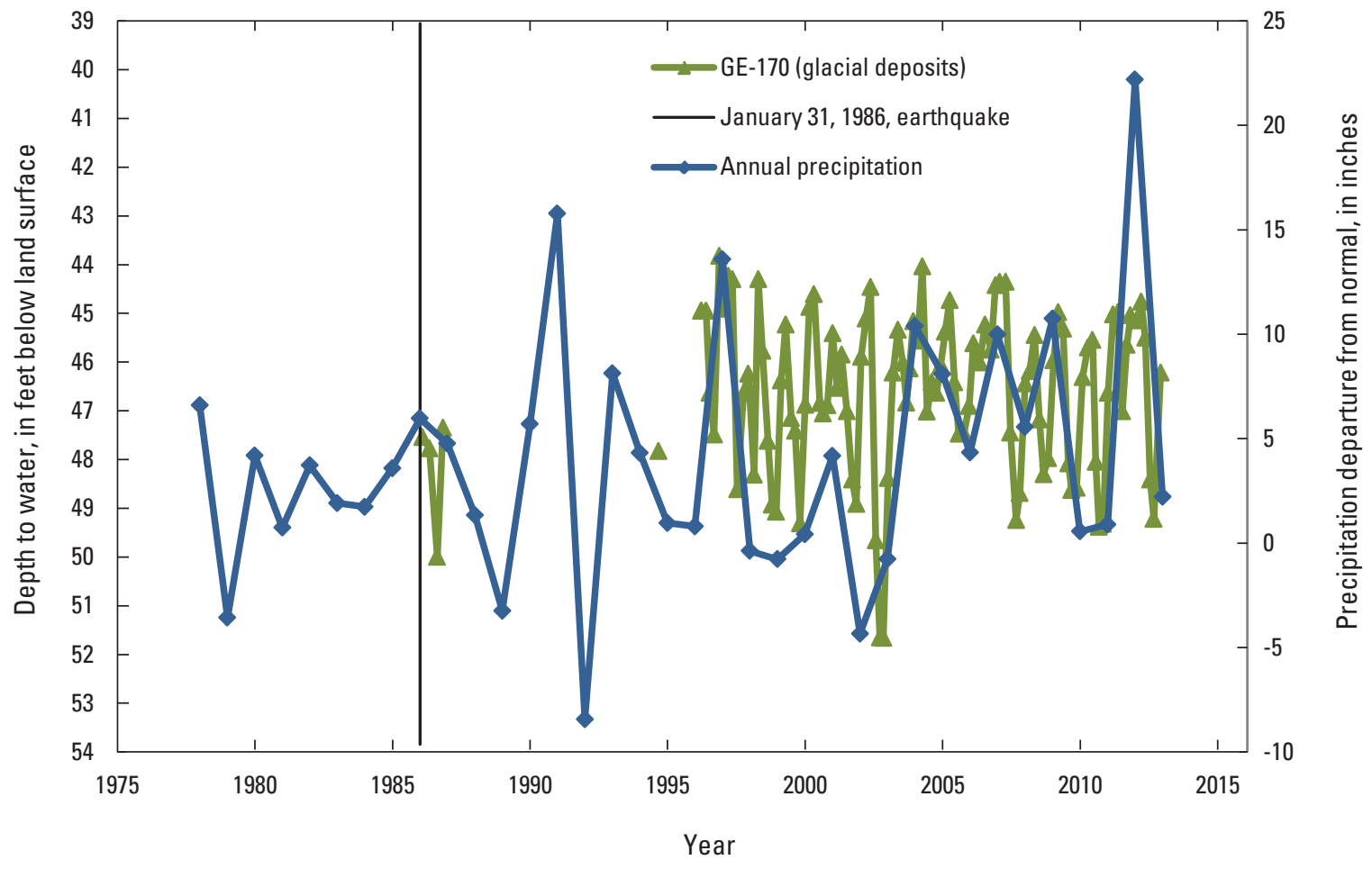

C. Wells showing departure from precipitation trend line some time after 1994

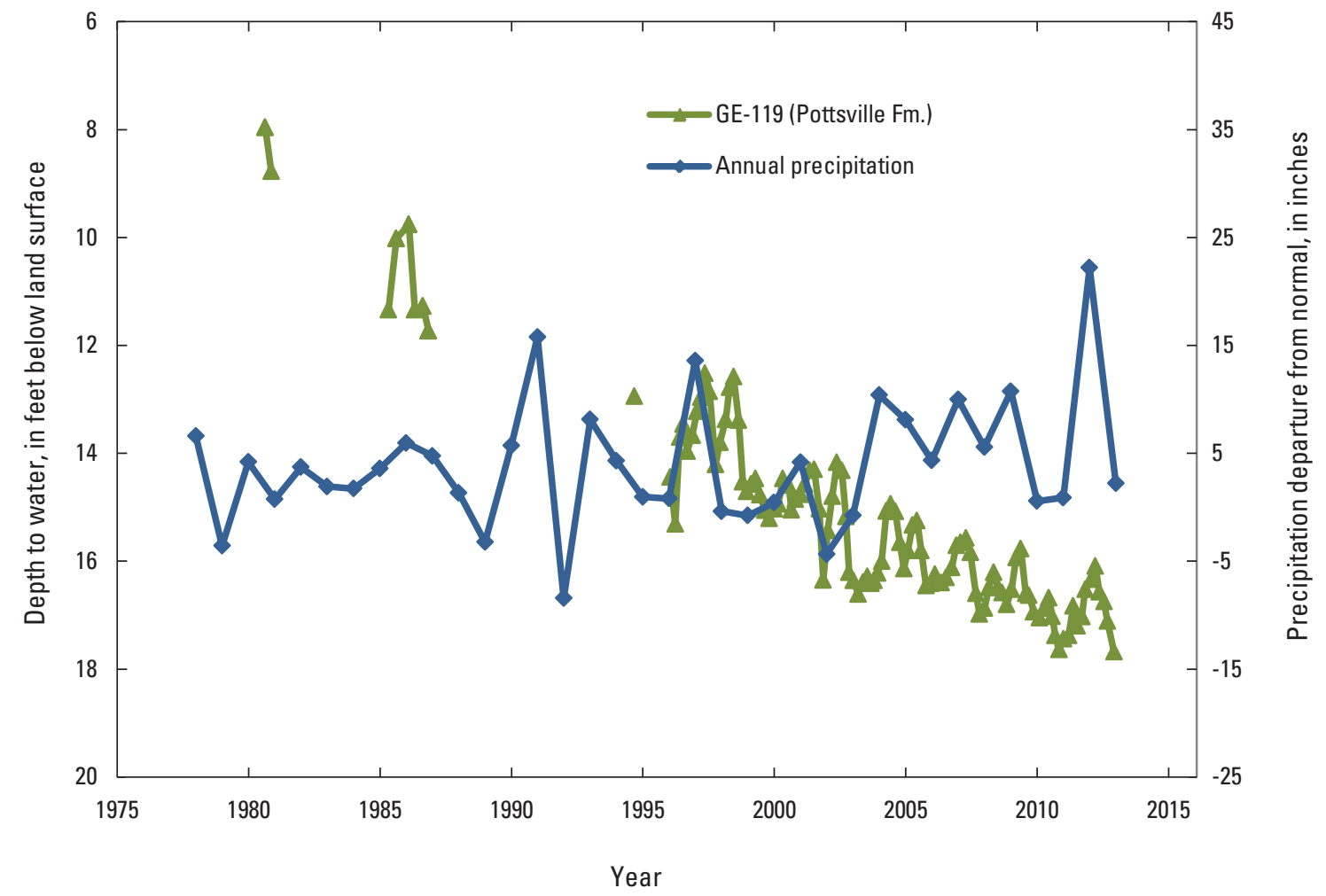

Figure 1-1. Relation of water levels in selected long-term network wells, 1978-2012, to variation in annual precipitation. (ft, feet; Fm., formation. Annual precipitation data are departure from normal for the climatological Northeast Region of Ohio [Ohio Department of Natural Resources, 1977-2012]. “Normal precipitation" and plotting conventions are described in appendix 1 text.) - Continued 
C. Wells showing departure from precipitation trend line some time after 1994—Continued
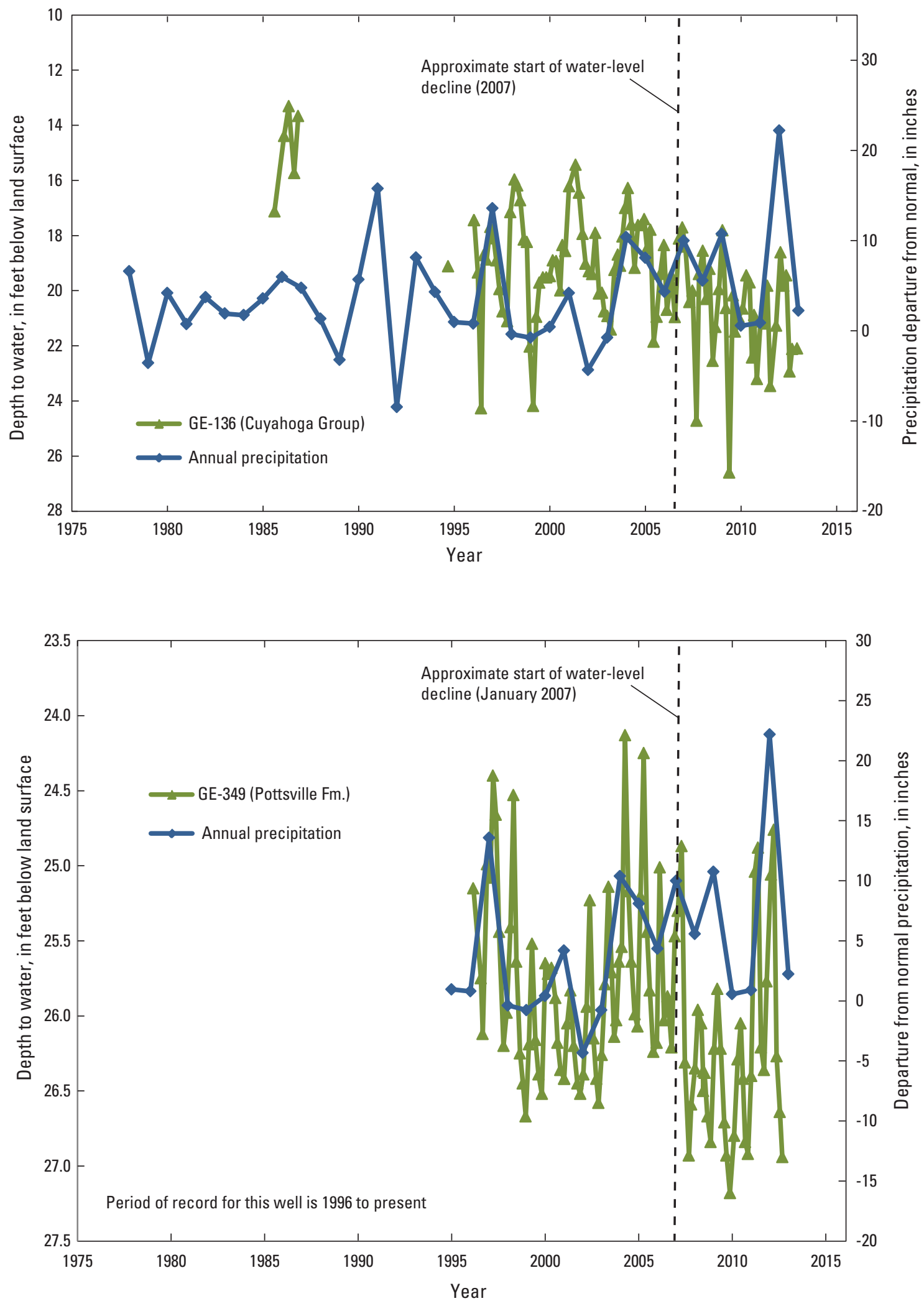

Figure 1-1. Relation of water levels in selected long-term network wells, 1978-2012, to variation in annual precipitation. (ft, feet; Fm., formation. Annual precipitation data are departure from normal for the climatological Northeast Region of Ohio [Ohio Department of Natural Resources, 1977-2012]. "Normal precipitation" and plotting conventions are described in appendix 1 text.)-Continued 
92 Groundwater Quality in Geauga County, Ohio-Status, 2009, and Changes During 1978-2009

C. Wells showing departure from precipitation trend line some time after 1994—Continued

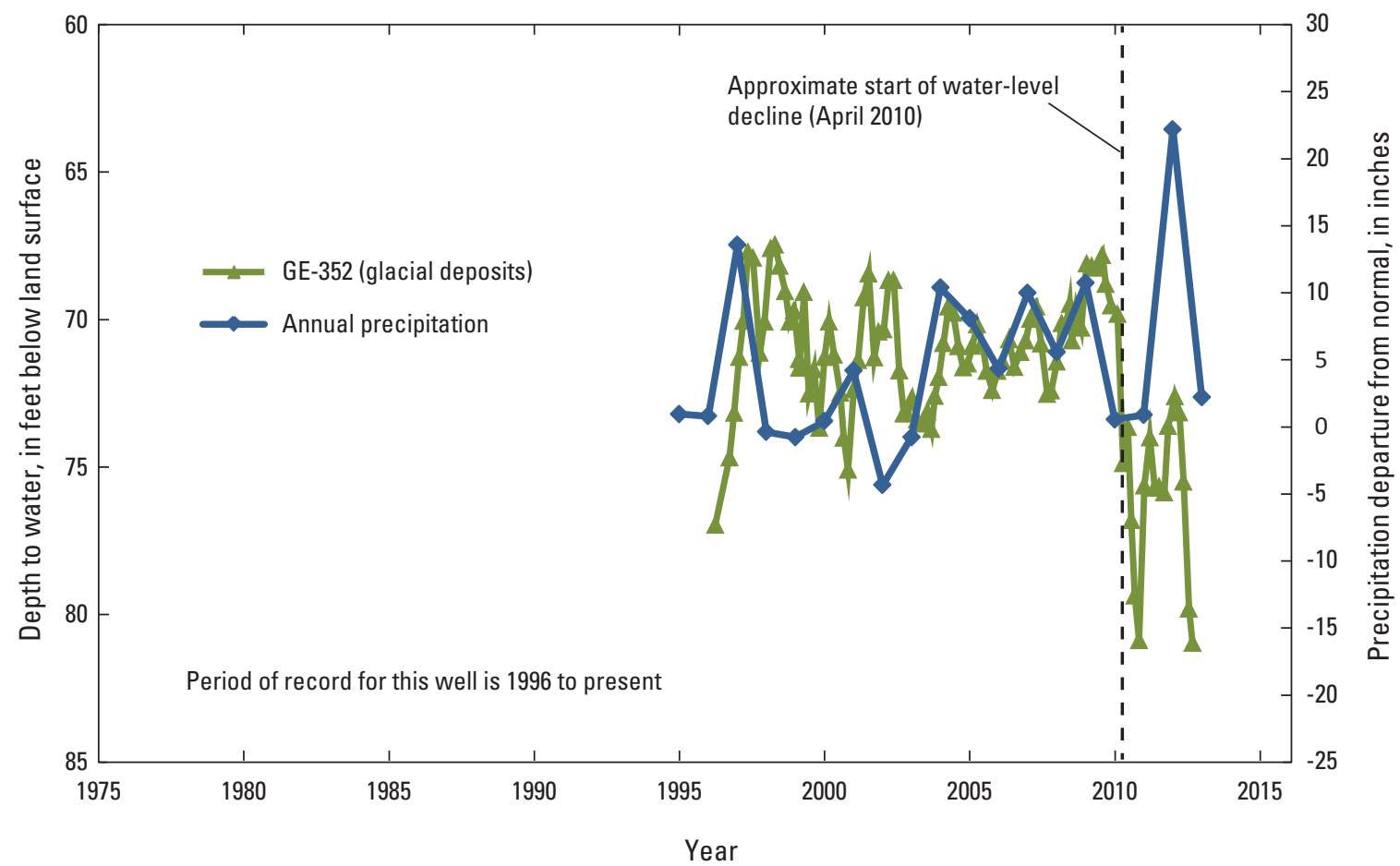

Figure 1-1. Relation of water levels in selected long-term network wells, 1978-2012, to variation in annual precipitation. (ft, feet; Fm., formation. Annual precipitation data are departure from normal for the climatological Northeast Region of Ohio [Ohio Department of Natural Resources, 1977-2012]. "Normal precipitation" and plotting conventions are described in appendix 1 text.)—Continued 


\section{Appendix 2. Quality Assurance/Quality Control}

To ensure sample integrity and final quality of data, quality-control (QC) samples - including sequential replicate samples, field blanks, and source solution blanks - were collected in 1999 and 2009 at a rate of 10 percent for most analytes (table 2-1). QC samples collected in 1999 are described by Jagucki and Darner (2001, appendix A). QC samples collected in 2009 are described below. QC data from years prior to 1999 were not available. To ensure that procedures were correctly and consistently followed, written protocols were distributed to field personnel, data entries were checked by a second person, and field personnel adhered to maximum sample holding times.

Assessing sampling and laboratory variability (within a sampling round).- Sequential replicates were collected in 1999 and 2009 for most constituents to assess sampling and analytical variability (Francy and Shaffer, 2008). Sequential replicates were collected from the same well immediately after the environmental sample by use of the same equipment and field methods, and they were analyzed for the same constituents as the environmental samples. (The exceptions were trace metals and tritium, for which no replicate samples were analyzed.) In 2009, replicate samples for alkalinity, major ions, iron, manganese, arsenic, sulfide, and organic carbon were collected at wells GE-165 and GE-341 (table 2-1). An additional replicate for alkalinity was collected at well GE-332. Replicate samples for pesticides and nutrients were collected from wells GE-332 and GE-341 because measurable concentrations of nitrate had been found in water from these wells during previous sampling rounds. Bacteria quality-assurance/quality-control (QA/QC) requirements were more stringent than requirements for other analytes. At all sites in 2009, duplicate platings were done from the same sample bottle but were counted by different analysts, and results were averaged. Additional platings were done from a second, replicate sample collected at well GE-341 (table 2-1) in 2009. Replicate samples for dissolved methane gas were collected at all three sites where the headspace screen detected combustible gas - GE-77, GE-126, and GE-147.

Results of replicate analyses are listed in table $2-1$, with the exception of results for replicate analyses of 52 pesticides that were not detected in any environmental or quality-control sample. Out of a total of 164 comparisons of replicate constituent analyses in 2009, 155 (94 percent) had a relative percent difference that was less than 5 percent. Only nine comparisons in 2009 and five in 1999 had relative percent differences that were greater than 5 percent; these are shown in bold type in table 2-1 and generally occurred at very low concentrations. When concentrations are low, a small amount of change in concentration in the replicate sample represents a large percent difference. Even for the nine problem values in 2009, the differences in concentration were not enough to change the determination of whether or not a constituent exceeded health-based or aesthetically based water-quality standards or changed the hazard level indicated by the measured methane concentrations.

Assessing sample contamination.-To identify bias caused by contamination from equipment, supplies, and ambient environmental conditions, one field blank was collected (Francy and Schaffer, 2008) in 2009 at a sampling location after the equipment had been cleaned. Cleaning, or decontamination, procedures are described in the Methods section of this report. The field blank for unfiltered constituents was collected by gravity-feeding deionized water through the sample tubing. For filtered constituents, a peristaltic pump was used to provide enough pressure to push the water through the filter. A portion of the water was collected and preserved for chemical analysis of major ions, iron, manganese, arsenic, and nutrients. The field blank for pesticides and dissolved organic carbon (DOC) used organicfree water rather than deionized water. For the DOC blank, the first 200 milliliters $(\mathrm{mL})$ of organic-free water was gravity-fed through the silicon sample tubing and then discarded. The subsequent water was forced through the DOC stainless steel filter cartridge by use of nitrogen gas.

One bottle of organic-free water was used in the process of preparing the pesticide and DOC field blank. When the bottle was opened, some of the unfiltered water was poured immediately into two sample containers and was sent to the NWQL for DOC and pesticide analysis to verify that the source water used to prepare the equipment blanks was organic free. This sample is referred to as the source-solution blank (Francy and Shaffer, 2008) (table 2-1).

It is expected that the blank sample collected in 2009 would have a measurable $\mathrm{pH}$ (because even deionized water has a $\mathrm{pH})$. However, concentrations of all other constituents in the blank were below the laboratory reporting level, except for the pesticide lindane, which had an estimated concentration of $0.006 \mu \mathrm{g} / \mathrm{L}$ (table 2-1). The low-level detection of lindane in the blank is not of concern, because lindane was not detected in the source-solution blank or in any environmental sample. In 1999, Jagucki and Darner (2001) found detectable levels of calcium, magnesium, sodium, silica, ammonia, orthophosphorous, iron, and boron in blank samples. In most cases, concentrations detected in the blanks were much less than concentrations in the environmental samples, often by two or more orders of magnitude. In no case was the concentration in the blank sample large enough to substantially affect the concentration of the constituent in the environmental samples.

Stringent equipment-blank procedures were applied to bacteria in 1999 and 2009. The sterility of the buffer water and the sterilization techniques for the membrane-filtration equipment were tested by processing an equipment blank before each water sample was filtered. No bacteria were detected in any of the equipment blanks in 1999 or 2009. This indicates that equipment, supplies, and ambient environmental conditions did not bias the bacteria analyses in any way. 


\section{Groundwater Quality in Geauga County, Ohio-Status, 2009, and Changes During 1978-2009}

Table 2-1. Chemical characteristics of selected quality-control samples collected in Geauga County, Ohio, June and July 1999 and June 2009 .

[Abbreviations: <, less than; col/100 mL, colonies per 100 milliliters; E. coli, Escherichia coli; $\mathrm{mg} / \mathrm{L}$, milligrams per liter; $\mu \mathrm{g} / \mathrm{L}$, micrograms per liter; REP, replicate; BLANK, field blank; SOURCE, source-solution blank; - , not analyzed for; E, estimated value, meaning that the value is lower than the laboratory reporting level but higher than the long-term method detection level for that analyte, as defined by Oblinger Childress and others (1999). An estimated (E) concentration has greater uncertainty than that of data reported without the "E" qualifier, but the chance that the analyte is really not present is 1 percent or less; boldface type indicates relative differences of 5 percent or greater. Gray shading indicates quality control (QC) samples collected in 2009. Pesticides listed in this table are those that were detected in one or more environmental samples. Other analyzed pesticides (listed in appendix table 4-2) were not detected in environmental or QC samples.]

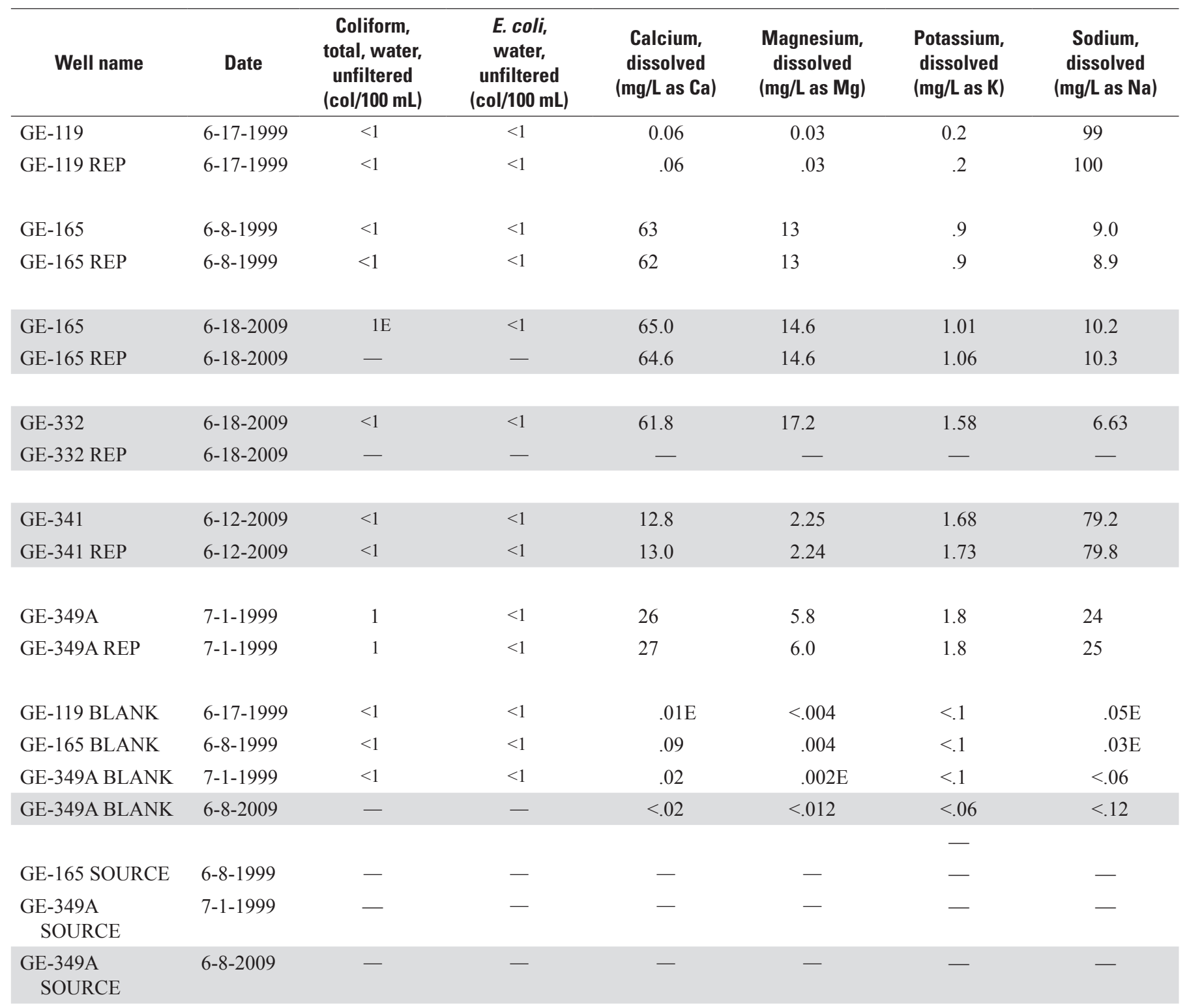


Table 2-1. Chemical characteristics of selected quality-control samples collected in Geauga County, Ohio, June and July 1999 and June 2009.-Continued

[Abbreviations: <, less than; mg/L, milligrams per liter; REP, replicate; BLANK, field blank; SOURCE, source-solution blank; 一, not analyzed for; boldface type indicates relative differences of 5 percent or greater. Gray shading indicates quality control (QC) samples collected in 2009.]

\begin{tabular}{|c|c|c|c|c|c|c|c|c|c|}
\hline Well name & Date & $\begin{array}{c}\text { Bicarbonate, } \\
\text { water, field } \\
(\mathrm{mg} / \mathrm{L} \text { as } \\
\left.\mathrm{HCO}_{3}\right)\end{array}$ & $\begin{array}{c}\text { Carbonate, } \\
\text { water, field } \\
(\mathrm{mg} / \mathrm{L} \text { as } \\
\left.\mathrm{CO}_{3}\right)\end{array}$ & $\begin{array}{c}\text { Alkalinity, } \\
\text { water, field } \\
\text { (mg/L as } \\
\mathrm{CaCO}_{3} \text { ) }\end{array}$ & $\begin{array}{c}\text { Sulfide, } \\
\text { total } \\
\text { (mg/L as S) }\end{array}$ & $\begin{array}{c}\text { Sulfate, } \\
\text { dissolved } \\
\left(\mathrm{mg} / \mathrm{L} \text { as SO } \mathrm{SO}_{4}\right)\end{array}$ & $\begin{array}{l}\text { Chloride, } \\
\text { dissolved } \\
\text { (mg/L as } \\
\text { Cl) }\end{array}$ & $\begin{array}{c}\text { Bromide, } \\
\text { dissolved } \\
\text { (mg/L as } \mathrm{Br} \text { ) }\end{array}$ & $\begin{array}{c}\text { Silica, } \\
\text { dissolved } \\
\text { (mg/L as } \\
\mathrm{SiO}_{2} \text { ) }\end{array}$ \\
\hline GE-119 & 6-17-1999 & 130 & 0 & 110 & 0.02 & 70 & 21 & 0.02 & 11 \\
\hline GE-119 REP & 6-17-1999 & 130 & 0 & 110 & - & 70 & 23 & .03 & 10 \\
\hline GE-165 & 6-8-1999 & 200 & 0 & 170 & .01 & 37 & 20 & .21 & 10 \\
\hline GE-165 REP & 6-8-1999 & 200 & 0 & 170 & .01 & 37 & 20 & .21 & 10 \\
\hline GE-165 & $6-18-2009$ & 215 & .3 & 177 & .020 & 34.7 & 28.9 & .11 & 11.2 \\
\hline GE-165 REP & $6-18-2009$ & 203 & .3 & 167 & .024 & 35.0 & 29.3 & .12 & 11.2 \\
\hline GE-332 & $6-18-2009$ & 175 & .1 & 144 & $<.005$ & 53.2 & 13.7 & .02 & 9.99 \\
\hline GE-332 REP & 6-18-2009 & 182 & .1 & 150 & - & - & - & - & - \\
\hline GE-341 & $6-12-2009$ & 6.4 & 0 & 4.7 & $<.005$ & 31.6 & 134 & .04 & 6.50 \\
\hline GE-341 REP & $6-12-2009$ & 5.4 & 0 & 3.8 & $<.005$ & 31.9 & 132 & .03 & 6.57 \\
\hline GE-349A & 7-1-1999 & 42 & 0 & 34 & $<.01$ & 35 & 43 & .05 & 8.0 \\
\hline GE-349A REP & 7-1-1999 & 40 & 0 & 30 & $<.01$ & 35 & 43 & .06 & 8.2 \\
\hline GE-119 BLANK & 6-17-1999 & - & - & - & - & $<.1$ & $<.1$ & $<.01$ & $<.05$ \\
\hline GE-165 BLANK & 6-8-1999 & - & - & - & - & $<.1$ & $<.1$ & $<.01$ & $<.05$ \\
\hline $\begin{array}{l}\text { GE-349A } \\
\text { BLANK }\end{array}$ & 7-1-1999 & - & - & - & - & $<.1$ & $<.1$ & $<.01$ & .05 \\
\hline $\begin{array}{l}\text { GE-349A } \\
\text { BLANK }\end{array}$ & $6-8-2009$ & - & - & - & - & $<.18$ & $<.12$ & $<.02$ & $<.02$ \\
\hline $\begin{array}{l}\text { GE-165 } \\
\text { SOURCE }\end{array}$ & 6-8-1999 & - & - & - & - & - & - & - & - \\
\hline $\begin{array}{l}\text { GE-349A } \\
\text { SOURCE }\end{array}$ & 7-1-1999 & - & - & - & - & - & - & - & - \\
\hline $\begin{array}{l}\text { GE-349A } \\
\text { SOURCE }\end{array}$ & $6-28-2009$ & - & - & - & - & - & - & - & - \\
\hline
\end{tabular}




\section{Groundwater Quality in Geauga County, Ohio-Status, 2009, and Changes During 1978-2009}

Table 2-1. Chemical characteristics of selected quality-control samples collected in Geauga County, Ohio, June and July 1999 and June 2009.-Continued

[Abbreviations: <, less than; mg/L, milligrams per liter; REP, replicate; BLANK, field blank; SOURCE, source-solution blank; - , not analyzed for; E, estimated value, meaning that the value is lower than the laboratory reporting level but higher than the long-term method detection level for that analyte, as defined by Childress and others (1999). An estimated (E) concentration has greater uncertainty than that of data reported without the "E" qualifier, but the chance that the analyte is really not present is 1 percent or less; boldface type indicates relative differences of 5 percent or greater. Gray shading indicates quality control (QC) samples collected in 2009.]

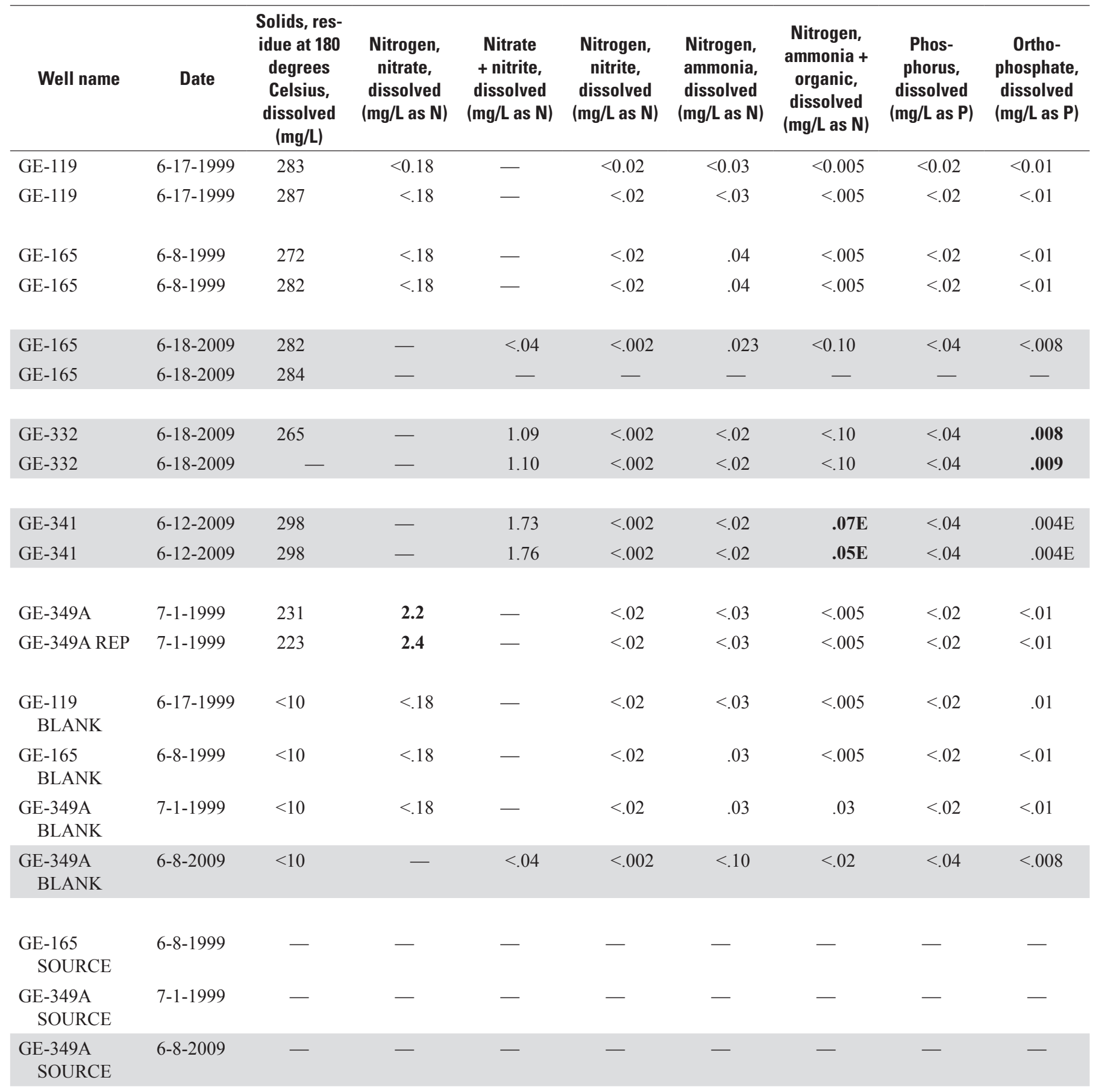


Table 2-1. Chemical characteristics of selected quality-control samples collected in Geauga County, Ohio, June and July, 1999 and June 2009.-Continued

[Abbreviations: <, less than; $\mathrm{mg} / \mathrm{L}$, milligrams per liter; $\mu \mathrm{g} / \mathrm{L}$, micrograms per liter; REP, replicate; BLANK, field blank; SOURCE, source-solution blank; -, not analyzed for; E, estimated value, meaning that the value is lower than the laboratory reporting level but higher than the long-term method detection level for that analyte, as defined by Oblinger Childress and others (1999). An estimated (E) concentration value has greater uncertainty than that of data reported without the "E" qualifier, but the chance that the analyte is really not present is 1 percent or less; boldface type indicates relative differences of 5 percent or greater. Gray shading indicates quality control (QC) samples collected in 2009. Pesticides listed in this table are those that were detected in one or more environmental samples. Other pesticides analyzed (listed in appendix table 4-2) were not detected in environmental or QC samples.]

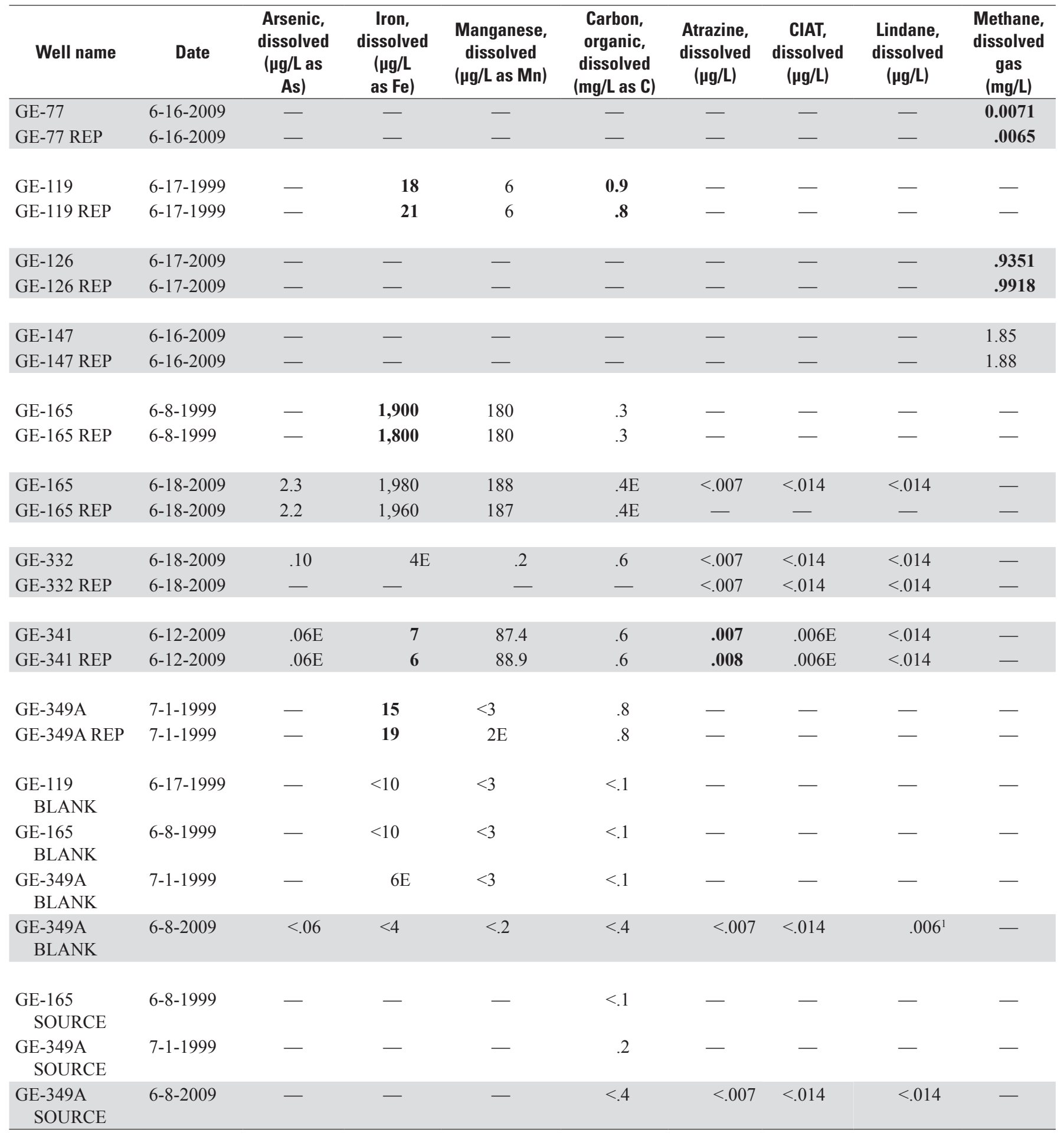

${ }^{1}$ The detected concentration was below the National Water Quality Laboratory's long-term method detection level as defined by Oblinger Childress and others (1999) for lindane in 2009 and thus has a level of uncertainty greater than that for estimated values. 


\section{Groundwater Quality in Geauga County, Ohio-Status, 2009, and Changes During 1978-2009}

Assessing holding time violations and identifying analytes that may be subject to degradation.-To ensure minimal degradation of sensitive constituents between the times of sample collection and analysis, $\mathrm{pH}$, dissolved oxygen, sulfide, alkalinity, and bacteria concentrations were analyzed in the field. Samples for other degradation-prone constituentsnutrients, DOC, and pesticides - were chilled and shipped to the laboratory as soon as possible, and holding times (time between sample collection and sample extraction or analysis) were monitored. In 2009, all samples for nutrients and DOC were analyzed within the maximum holding times of 30 days and 28 days, respectively. However, three pesticide samples (GE-77, GE-141, and GE-147), exceeded the maximum holding time of 7 days (from sampling to extraction). Holding times for these samples were 8 days, based on sample preparation records at the National Water Quality Laboratory. According to Duane Wydoski, Supervisory Chemist at the laboratory (2010, written commun. on file at the USGS Ohio Water Science Center in Columbus, Ohio), a review of available holding-time studies (Zaugg and others, 1995; Sandstrom and others, 2001; and one unpublished 2004 study) indicates that two of the pesticides analyzed for would have degraded somewhat after 6 or 7 days. These two compounds are alpha-endosulfan and malathion; most of the other pesticides would not be affected by the holding-time exceedance.

Assessing laboratory bias and variability over time (between sampling rounds). - To determine and track the degree of uncertainty associated with the measured values of chemical concentration over time, the Branch of Quality Systems operates independent, external, blind sample projects for both inorganic (Inorganic Blind Sample Project) and organic (Organic Blind Sample Project) constituents (U.S. Geological Survey, 2010). Through these projects, "blind" QA samples are submitted for analysis, meaning that concentration levels in the samples are unknown to the analyst. For the inorganic blind samples, the identity of the samples is unknown as well (“double blind"). Blind QA samples contain selected inorganic, organic, and nutrient constituents at various concentrations and are disguised as routine environmental samples. Staff of the blind sample projects take the constituent concentration measured by the NWQL in the blind QA sample, divide by the expected concentration, and multiply by 100 to get a percent recovery. Percent recovery is then plotted over time (fig. 2-1) to determine laboratory bias and variability. A long-term positive bias in percent recovery as viewed on a time-series chart means that if the laboratory analyzed the same sample each year (and the sample did not degrade), that each year the laboratory would report a higher than actual concentration of the analyte in that sample. Blind-sample data for many inorganic constituents are available from 1984 to present. Blind-sample data for organic constituents may go back as far as the mid- to late 1990 s.

To determine whether the changes in constituent concentrations observed between 1986 and 1999 (table 8A) or 1999 and 2009 in samples from Geauga County (table $8 B$ ) were greater than changes expected due to laboratory recovery, blind-sample project data were used to calculate the median percent recovery for each constituent of interest for a 3-month period (shown as gray shading in fig. 2-1) centered on the date of sampling for the 1999 and 2009 sampling rounds (or, in the case of chloride, for a 3-month period centered on the date of sampling for the 1986 and 1999 sampling rounds ${ }^{1}$ ). The median constituent concentration measured in 1999 (in paired wells only) was then multiplied by the ratio of the median 2009 recovery to the median 1999 recovery to calculate the expected median concentration in 2009 if concentration differences were due solely to changes in laboratory recovery over time (table 2-2) ${ }^{2}$. For chloride, magnesium, and organic carbon, the actual median concentration in 2009 (or for chloride, in 1999) in paired wells, taking into account sampling and laboratory variability as indicated by replicate samples (last column, table 2-2) was appreciably different than the expected median concentration based on laboratory recovery alone (table 2-2). Thus, the observed changes over time in concentrations of these constituents likely are not caused solely by changes in recovery and sampling and laboratory variability. In contrast, the expected median concentration for silica in 2009 was $13.0 \mathrm{mg} / \mathrm{L}$ (based solely on laboratory recovery); this fell within the range of the actual (measured) median concentration plus or minus maximum difference in replicate samples (12.2-14.2 milligrams per liter, table 2-2). Thus, the difference in silica concentrations between 1999 and 2009, although statistically significant (table $8 B$ ), may not result from a change in the groundwater chemistry over time but instead may be caused by laboratory bias.

Because the Inorganic Blind Sample Project did not begin collecting blind-sample results for bromide until 2010, expected variations in measured concentration caused by changes in laboratory recovery could not be calculated. However, to obtain the bromide concentrations observed in 2009 given 1999 concentrations (and calculated as if the change from 1999 to 2009 were a result of changes in laboratory recovery alone) would require a recovery ratio of 0.50 , which is much smaller than recovery ratios for other constituents in table 2-2 and would be outside of the typical range of recovery ratios ( 0.90 to 1.10$)$ expected for concentrations well above the long-term method detection level (Tedmund Struzeski, 2011, written commun. on file at the USGS Ohio Water Science Center in Columbus). Thus, observed changes in bromide concentration over time likely result from actual changes in groundwater chemistry. Because

\footnotetext{
${ }^{1}$ The calculation of median percent recovery for each date range was limited to laboratory spike concentrations equal to the range of concentrations measured in environmental samples plus or minus 4 milligrams per liter.

${ }^{2}$ This comparison of environmental sample concentrations to blind-sample recoveries assumes that the effect of the sample matrix on analytical results is similar for both environmental and blind samples. (The inorganic blind samples are derived from natural surface-water sources.)
} 

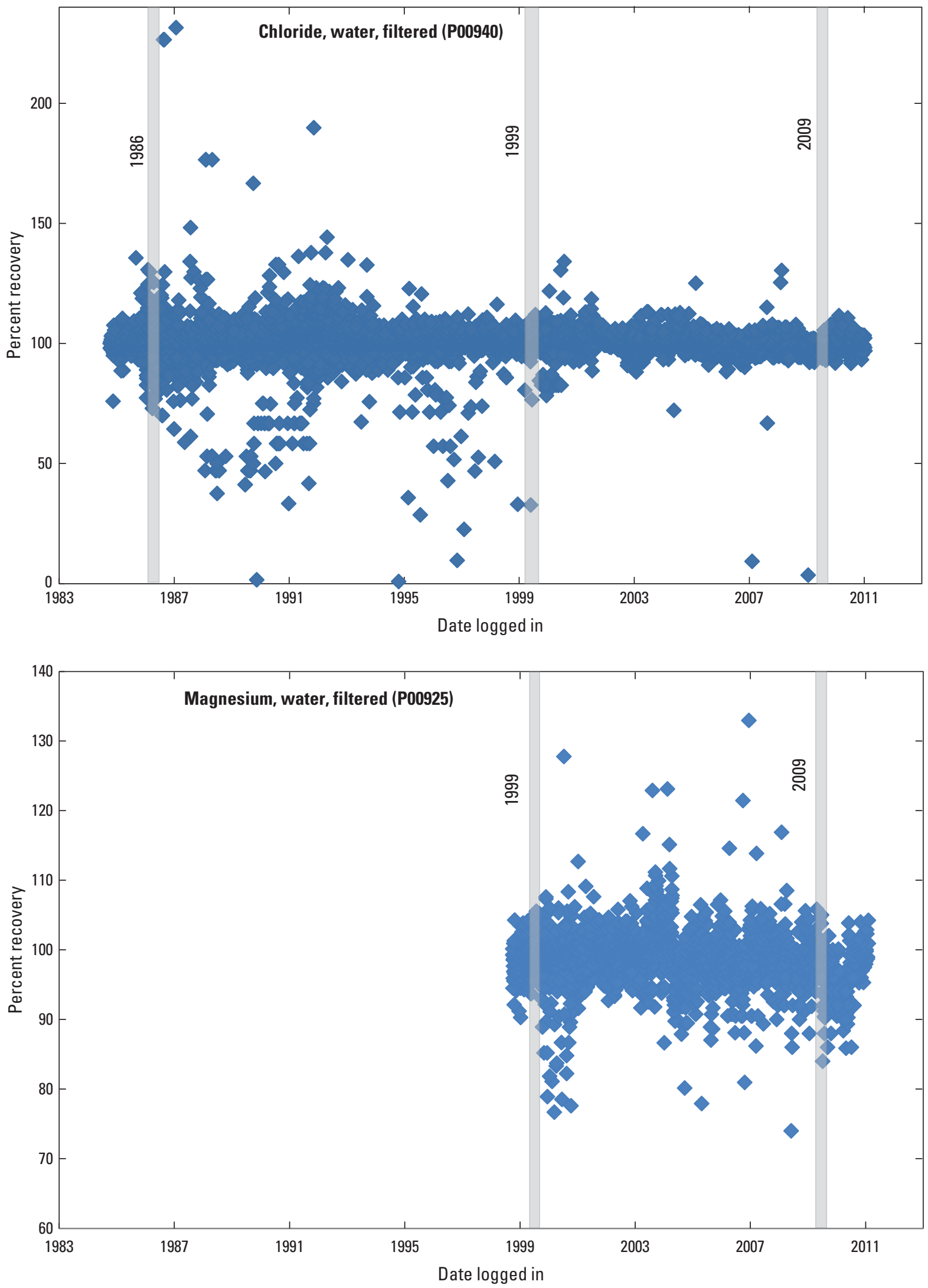

Figure 2-1. Changes in percent recovery over time for selected constituents analyzed by the National Water Quality Laboratory. (Shaded gray bands indicate a 3-month period centered on the date of each groundwater-sampling round. Number in parentheses is the laboratory parameter code.) 

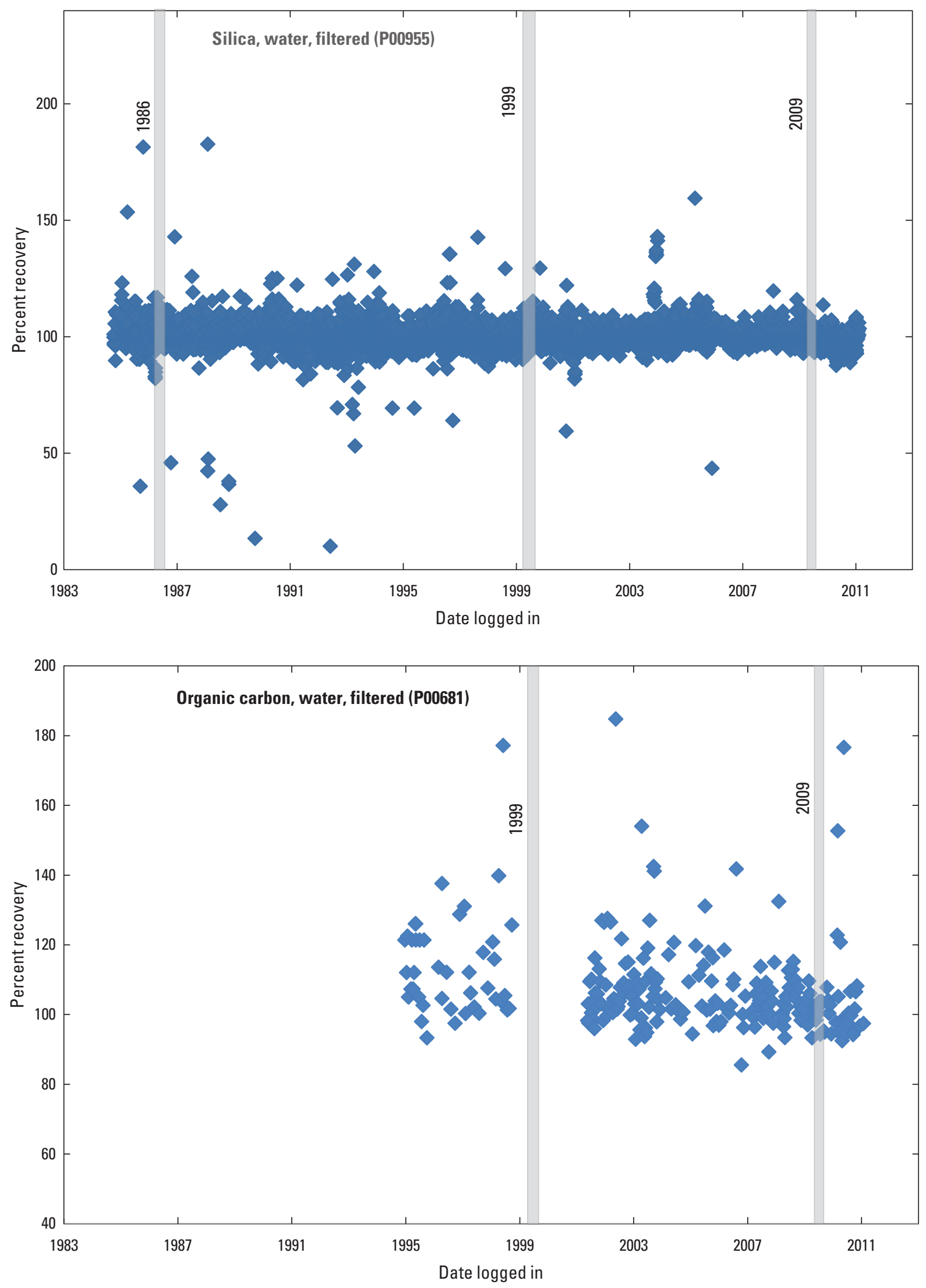

Figure 2-1. Changes in percent recovery over time for selected constituents analyzed by the National Water Quality Laboratory. (Shaded gray bands indicate a 3-month period centered on the date of each groundwater-sampling round. Number in parentheses is the laboratory parameter code.)—Continued 

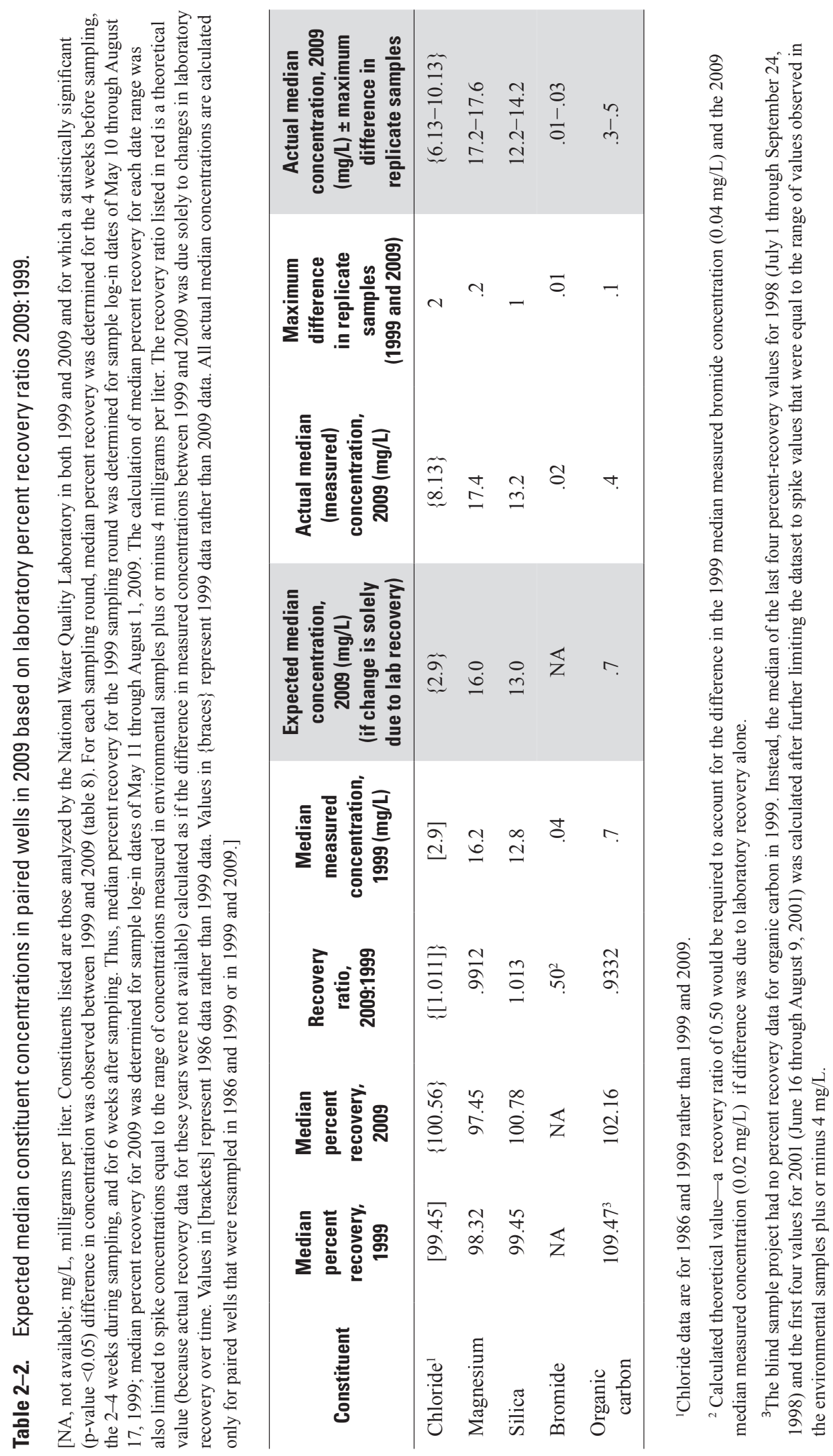
ammonia analyses were done by Heidelberg University laboratory (rather than the NWQL) in 1999, it was not appropriate to assess laboratory bias and variability over time for ammonia using typical NWQL recovery ratios.

Percent recovery data do not exist for other properties and constituents with statistically significant changes in concentration over time - dissolved oxygen, $\mathrm{pH}$, specific conductance, and alkalinity - because these concentrations were measured in the field rather than in the laboratory. However, field instruments were calibrated daily during the sample collection period and were not prone to excessive drift. Additionally, the dissolved oxygen meter was tested at the end of the sampling round and accurately measured a lowdissolved oxygen calibrant that was not available in the field. Lastly, the field analysts and instruments had passed annual tests of proficiency as part of the Branch of Quality Systems National Field Quality Assurance Project. For three of the field parameters, the changes in sample measurements from 1999 to 2009 were compared relative to stabilization criteria for recording field measurements, as specified in the USGS Field
Manual (U.S. Geological Survey, 1997-present) and as shown in table 2-3. (Stabilization criteria have not been established for alkalinity.) These stabilization criteria reflect "the accuracy that should be obtainable with a calibrated instrument" that has equilibrated to the temperature of the water being sampled, given "the natural variability inherent in... groundwater" pumped through a flowthrough chamber at the time of sampling. Median concentrations of dissolved oxygen and $\mathrm{pH}$ for environmental samples in 2009 were outside of the range of 1999 median concentrations plus or minus the stabilization criteria (table 2-3). Thus, the statistically significant differences in concentrations of these constituents from 1999 to 2009 (table 8B) likely represent actual changes in groundwater chemistry. However, median specific conductance for environmental samples in 2009 is within the range of the 1999 median value plus or minus the stabilization criteria (table 2-3), suggesting that the differences listed in table $8 B$ may represent instrument variability rather than a change in groundwater chemistry.

Table 2-3. Comparison of median values of dissolved oxygen, $\mathrm{pH}$, and specific conductance in 2009 to expected variation in 1999 median values caused by measurement stabilization for 16 paired wells.

$[\mathrm{mg} / \mathrm{L}$, milligrams per liter; $\mu \mathrm{S} / \mathrm{cm}$, microsiemens per centimeter at 25 degrees Celsius. Stabilization criteria are from U.S. Geological Survey, 1997-present]

\begin{tabular}{llccc}
\hline \multicolumn{1}{c}{ Constituent } & $\begin{array}{c}\text { Stabilization } \\
\text { criterion }\end{array}$ & $\begin{array}{c}\text { Median value } \\
\mathbf{1 9 9 9}\end{array}$ & $\begin{array}{c}\text { Median value 1999 } \\
\text { stabilization criterion }\end{array}$ & $\begin{array}{c}\text { Median value } \\
\mathbf{2 0 0 9}\end{array}$ \\
\hline Dissolved oxygen $(\mathrm{mg} / \mathrm{L})$ & $\pm 0.3 \mathrm{mg} / \mathrm{L}$ & 0.1 & $0-0.4$ & 1.05 \\
$\mathrm{pH}$ & \pm 0.1 & 7.4 & $7.3-7.5$ & 7.2 \\
Specific conductance $(\mu \mathrm{S} / \mathrm{cm})$ & \pm 3 percent & 500 & $485-515$ & 509 \\
\hline
\end{tabular}




\section{Appendix 3. Land Cover and Population Upgradient of Each Well}

Table 3-1. Land-cover types, population, number of acres permitted for biosolids spreading, and number of producing oil and gas wells upgradient of 16 domestic wells sampled in 2009, and 7 selected water-supply well fields in Geauga County, Ohio.

[-, no permitted biosolids spreading or producing oil and gas wells located upgradient of well. Characteristics shown in table are within a 500 meter-radius quarter circle oriented hydraulically upgradient of the well. Data sources are as follows: Percent land cover types, 2001 National Land Cover Database (Homer and others, 2007); number of people, U.S. Census Bureau (2010); number of acres permitted for biosolids application, Ohio Environmental Protection Agency (2010a); number of producing oil and gas wells, Ohio Department of Natural Resources (2008a)]

\begin{tabular}{|c|c|c|c|c|c|c|c|c|c|c|}
\hline \multirow{2}{*}{$\begin{array}{l}\text { Well } \\
\text { name }\end{array}$} & \multicolumn{7}{|c|}{ Percent land-cover types } & \multirow{2}{*}{$\begin{array}{c}\text { Number } \\
\text { of people } \\
\text { (year 2000) }\end{array}$} & \multirow{2}{*}{$\begin{array}{c}\text { Number } \\
\text { of acres } \\
\text { permitted } \\
\text { for } \\
\text { biosolids } \\
\text { spreading }\end{array}$} & \multirow{2}{*}{$\begin{array}{c}\text { Number of } \\
\text { producing } \\
\text { oil and } \\
\text { gas wells }\end{array}$} \\
\hline & Developed & Water & Forest & $\begin{array}{l}\text { Shrub/ } \\
\text { Scrub }\end{array}$ & $\begin{array}{l}\text { Grass- } \\
\text { land }\end{array}$ & $\begin{array}{l}\text { Agricul- } \\
\text { ture }\end{array}$ & Wetland & & & \\
\hline \multicolumn{11}{|c|}{ Domestic wells } \\
\hline GE-77 & 45.83 & 0 & 43.98 & 0 & 10.19 & 0 & 0 & 34 & - & - \\
\hline GE-85A & 58.37 & 0 & 14.48 & 0 & 11.31 & 15.84 & 0 & 7 & - & - \\
\hline GE-103 & 13.55 & 0 & 7.01 & 0 & 1.87 & 77.10 & 0.47 & 12 & - & 1 \\
\hline GE-108 & 20.18 & 0 & 79.82 & 0 & 0 & 0 & 0 & 12 & - & - \\
\hline GE-109 & 4.07 & 0 & 50.23 & 0 & 1.36 & 44.34 & 0 & 20 & - & - \\
\hline GE-120 & 24.66 & 0 & 33.79 & 0 & 41.55 & 0 & 0 & 31 & - & - \\
\hline GE-126 & 37.90 & 0 & 29.22 & 0 & 4.57 & 28.31 & 0 & 17 & - & - \\
\hline GE-141 & 9.09 & 0 & 21.36 & 0 & 0 & 69.55 & 0 & 20 & 9.91 & - \\
\hline GE-147 & 51.60 & 0 & 1.83 & 0 & 0 & 46.58 & 0 & 15 & - & - \\
\hline GE-151 & 7.34 & 0 & 60.55 & 0 & 21.10 & 11.01 & 0 & 14 & - & - \\
\hline GE-165 & 16.97 & 0 & 0.46 & 0 & 0 & 82.57 & 0 & 22 & - & - \\
\hline GE-185A & 33.93 & 0 & 34.82 & 0 & 8.04 & 23.21 & 0 & 26 & - & - \\
\hline GE-202 & 4.11 & 2.74 & 59.36 & 0 & 0 & 33.79 & 0 & 7 & - & - \\
\hline GE-234 & 29.30 & 0 & 38.60 & 0 & 0 & 31.16 & 0.93 & 10 & - & - \\
\hline GE-332 & 66.67 & 0 & 26.48 & 0 & 0.91 & 5.94 & 0 & 69 & - & - \\
\hline GE-341 & 0.46 & 0 & 2.28 & 0 & 5.48 & 91.78 & 0 & 3 & - & - \\
\hline \multicolumn{11}{|c|}{ Public-supply wells } \\
\hline $\begin{array}{l}\text { ASM } \\
\text { Interna- } \\
\text { tional }\end{array}$ & 43.38 & 0 & 56.62 & 0 & 0 & 0 & 0 & 23 & - & - \\
\hline $\begin{array}{l}\text { Burton } \\
\text { Village }\end{array}$ & 1.37 & 16.89 & 42.47 & 2.28 & 0.91 & 0 & 36.07 & 1 & - & - \\
\hline $\begin{array}{c}\text { Chardon } \\
\text { City }\end{array}$ & 39.81 & 0 & 52.31 & 3.70 & 0 & 0 & 4.17 & 14 & - & - \\
\hline $\begin{array}{l}\text { Christ } \\
\text { Presbyte- } \\
\text { rian }\end{array}$ & 90.41 & 0 & 9.13 & 0 & 0.46 & 0 & 0 & 58 & - & 1 \\
\hline $\begin{array}{l}\text { Lake } \\
\quad \text { Lucerne }\end{array}$ & 86.76 & 0 & 10.05 & 0 & 3.20 & 0 & 0 & 177 & - & - \\
\hline $\begin{array}{l}\text { Middlefield } \\
\text { Village }\end{array}$ & 12.27 & 0 & 0 & 0 & 5.91 & 81.82 & 0 & 8 & - & - \\
\hline $\begin{array}{l}\text { Tanglewood } \\
\text { Lake }\end{array}$ & 26.36 & 0 & 31.36 & 0 & 0 & 42.27 & 0 & 47 & - & 1 \\
\hline
\end{tabular}




\section{Appendix 4. Water-Quality Data}

Well-selection notes: Samples that were determined to have passed through household water softeners were removed from the dataset of all water samples collected by the U.S. Gelolgical survey in Geauga County, Ohio, 1978-2009 (fig. 4-1 and table 4-1). Samples from 1986 that specifically targeted brines and wells suspected by homeowners to be brine contaminated were also removed. Additionally, wells completed solely in the Bedford Shale underlying the Berea Sandstone were removed from the dataset because this is not one of the four primary aquifers used in the county.

\section{Figures}

4-1. Locations of wells sampled by the U.S. Geological Survey in Geauga County, Ohio, 1978-2009 105

\section{Tables}

4-1. Selected chemical characteristics of water samples collected by the U.S. Geological Survey in Geauga County, Ohio, 1978-2009. (Table, in Excel format, is available at http://dx.doi.org/10.3133/sir20155032)

4-2. Pesticides analyzed for in groundwater samples from 16 domestic wells in Geauga County, June 2009.

4-3. Volatile organic compounds and semivolatile organic compounds analyzed for in groundwater samples in Geauga County, Ohio, 1995-2009 


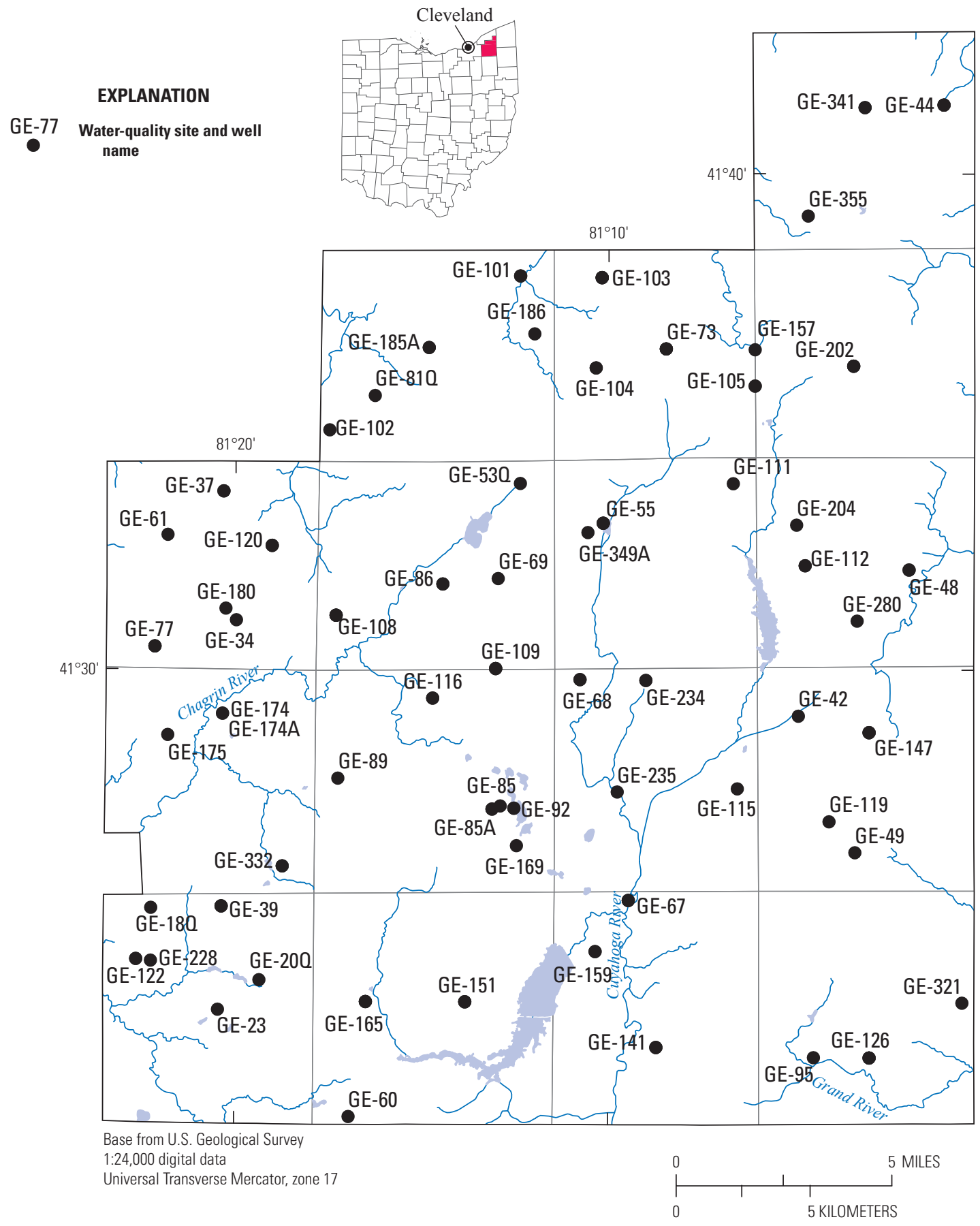

Figure 4-1. Locations of wells sampled by the U.S. Geological Survey in Geauga County, Ohio, 1978-2009. 
Table 4-2. Pesticides analyzed for in groundwater samples from 16 domestic wells in Geauga County, June 2009.

[MCL, Maximum Contaminant Level; HA-L, lifetime health advisory; HA-C, $10^{-6}$ cancer risk concentration; $\mu \mathrm{g} / \mathrm{L}$, micrograms per liter; - , no benchmark available. Human-health benchmarks are defined in sidebar, p.27, and are from http://water.usgs.gov/nawqa/pnsp/benchmarks/ (searchable online database for Health-Based Screening Levels, updated Feb. 28, 2012). This table is modified from DeSimone and others, 2009, table 4-1.]

\begin{tabular}{|c|c|c|c|c|c|}
\hline \multirow{2}{*}{$\begin{array}{l}\text { Pesticide compound } \\
\text { (dissolved) }\end{array}$} & \multirow{2}{*}{$\begin{array}{c}\text { Type of pesticide } \\
\text { compound (parent } \\
\text { pesticide, if degradate) }\end{array}$} & \multicolumn{2}{|c|}{ Human-health benchmarks } & \multirow{2}{*}{$\begin{array}{l}\text { Laboratory } \\
\text { reporting level, } \\
\text { in micrograms } \\
\text { per liter ( } \mu \mathrm{g} / \mathrm{L} \text { ) }\end{array}$} & \multirow{2}{*}{$\begin{array}{l}\text { Number o } \\
\text { detections }\end{array}$} \\
\hline & & Source & Value ( $\mu \mathrm{g} / \mathrm{L})$ & & \\
\hline 2,6-Diethylaniline & Degradate (Alachlor) & - & - & 0.006 & 0 \\
\hline $\begin{array}{l}\text { 2-Chloro-4-isopropylamino-6- } \\
\text { amino- } s \text {-trianzine (CIAT) }\end{array}$ & Degradate (Atrazine) & - & - & .014 & $1^{1}$ \\
\hline Acetochlor & Herbicide & $\mathrm{HA}-\mathrm{C}$ & 10 & .01 & 0 \\
\hline Alachlor & Herbicide & MCL & 2 & .008 & 0 \\
\hline alpha-HCH & Degradate (Lindane) & $\mathrm{HA}-\mathrm{C}$ & .006 & .008 & 0 \\
\hline Butylate & Herbicide & HA-L & 400 & .002 & 0 \\
\hline Carbaryl & Insecticide & $\mathrm{HA}-\mathrm{C}$ & 40 & .2 & 0 \\
\hline Carbofuran & Insecticide & MCL & 40 & .06 & 0 \\
\hline Chlorpyrifos & Insecticide & HA-L & 2 & $.01^{2}$ & 0 \\
\hline cis-Permethrin & Insecticide & $\mathrm{HA}-\mathrm{C}$ & 4 & .014 & 0 \\
\hline Cyanazine & Herbicide & HA-L & 1 & .04 & 0 \\
\hline EPTC & Herbicide & HA-L & 200 & .002 & 0 \\
\hline Ethalfluralin & Herbicide & HA-L & 30 & .009 & 0 \\
\hline Ethoprop (Ethoprophos) & Herbicide & $\mathrm{HA}-\mathrm{C}$ & 1 & .016 & 0 \\
\hline Desulfinylfipronil amide & Degradate (Fipronil) & - & - & .029 & 0 \\
\hline Fipronil sulfide & Degradate (Fipronil) & - & - & .013 & 0 \\
\hline Fipronil sulfone & Degradate (Fipronil) & - & - & .024 & 0 \\
\hline Fipronil & Insecticide & HA-L & .1 & .04 & 0 \\
\hline Fonofos & Insecticide & HA-L & 10 & .01 & 0 \\
\hline Lindane (gamma-HCH) & Insecticide & MCL & .2 & .014 & 0 \\
\hline
\end{tabular}


Table 4-2. Pesticides analyzed for in groundwater samples from 16 domestic wells in Geauga County, June 2009.—Continued

[MCL, Maximum Contaminant Level; HA-L, lifetime health advisory; HA-C, $10^{-6}$ cancer risk concentration; $\mu \mathrm{g} / \mathrm{L}$, micrograms per liter; - , no benchmark available. Human-health benchmarks are defined in sidebar, p.27, and are from http://water.usgs.gov/nawqa/pnsp/benchmarks/ (searchable online database for Health-Based Screening Levels, updated Feb. 28, 2012). This table is modified from DeSimone and others, 2009, table 4-1.]

\begin{tabular}{|c|c|c|c|c|c|}
\hline \multirow{2}{*}{$\begin{array}{l}\text { Pesticide compound } \\
\text { (dissolved) }\end{array}$} & \multirow{2}{*}{$\begin{array}{c}\text { Type of pesticide } \\
\text { compound (parent } \\
\text { pesticide, if degradate) }\end{array}$} & \multicolumn{2}{|c|}{ Human-health benchmarks } & \multirow{2}{*}{$\begin{array}{c}\text { Laboratory } \\
\text { reporting level, } \\
\text { in micrograms } \\
\text { per liter ( } \mu \mathrm{g} / \mathrm{L})\end{array}$} & \multirow{2}{*}{$\begin{array}{l}\text { Number } 0 \\
\text { detection }\end{array}$} \\
\hline & & Source & Value $(\mu \mathrm{g} / \mathrm{L})$ & & \\
\hline Linuron & Herbicide & HA-L & 5 & 0.06 & 0 \\
\hline Malathion & Insecticide & HA-L & 500 & .02 & 0 \\
\hline Methyl parathion & Insecticide & HA-L & 1 & .008 & 0 \\
\hline Metolachlor & Herbicide & HA-L & 700 & .014 & 0 \\
\hline Metribuzin & Herbicide & HA-L & 90 & .016 & 0 \\
\hline Molinate & Herbicide & HA-L & .7 & .002 & 0 \\
\hline Napropamide & Herbicide & HA-L & 800 & .018 & 0 \\
\hline$p, p^{\prime}-\mathrm{DDE}$ & Degradate $\left(p, p^{\prime}\right.$-DDT) & HA-C & .1 & .003 & 0 \\
\hline Parathion (Ethyl parathion) & Insecticide & HA-L & .02 & .02 & 0 \\
\hline Pebulate & Herbicide & HA-L & 50 & .016 & 0 \\
\hline Pendimethalin & Herbicide & HA-L & 20 & .012 & 0 \\
\hline Phorate & Insecticide & HA-L & 4 & .02 & 0 \\
\hline Prometon & Herbicide & HA-L & 400 & .012 & 0 \\
\hline Propyzamide (Pronamide) & Herbicide & $\mathrm{HA}-\mathrm{C}$ & 1 & .004 & 0 \\
\hline Propachlor & Herbicide & HA-C & 1 & .012 & 0 \\
\hline Propanil & Herbicide & HA-L & 6 & .014 & 0 \\
\hline Propargite & Acaricide & HA-C & 1 & .02 & 0 \\
\hline Simazine & Herbicide & MCL & 4 & .01 & 0 \\
\hline Tebuthiuron & Herbicide & HA-L & 1,000 & .02 & 0 \\
\hline Terbacil & Herbicide & HA-L & 100 & .04 & 0 \\
\hline Terbufos & Insecticide & HA-L & .4 & .018 & 0 \\
\hline Thiobencarb & Herbicide & HA-L & 70 & .016 & 0 \\
\hline Triallate & Herbicide & HA-L & 20 & .006 & 0 \\
\hline Trifluralin & Herbicide & HA-L & 20 & .012 & 0 \\
\hline
\end{tabular}

${ }^{1}$ This detection was an estimated concentration that was below the long-term method detection level (LT-MDL). Unlike other reported concentrations, there is less than 99 percent confidence that this analyte concentration is greater than zero.

${ }^{2}$ An interim reporting level was used for chlorpyrifos, because the analytical method did not have at least one year's worth of supporting data to determine a LT-MDL and corresponding laboratory reporting level (calculated as the LT-MDL multiplied by two). The interim reporting level is at least two times the estimated detection limit. 
Table 4-3. Volatile organic compounds and semivolatile organic compounds analyzed for in groundwater samples in Geauga County, Ohio, 1995-2009.

[USGS, water samples from 31 domestic wells analyzed by U.S. Geological Survey personnel in 1999 (Jaguck and Darner, 2001); Public-supply well data were compiled from Ohio Environmental Protection Agency's Ambient Ground Water Monitoring Well Network program (untreated water samples from ASM International, Middlefield Village, and Tanglewood Lake) and compliance data from public-supply wells submitted to Ohio Environmental Protection Agency's Safe Drinking Water Information System database (untreated and treated water samples from Burton Village, Chardon City; Christ Presbyterian Church, Lake Lucerne Club Co., Middlefield Village; and Tanglewood Lake Water Co.). Locations of public-supply wells are shown in fig. 12; well identifiers and corresponding public-supply well names are listed in table 4. Orange shading indicates the compound is produced as a byproduct of drinking-water chlorination; $\bullet$, analyzed for but not detected ${ }^{1} ; \boldsymbol{\Lambda}$, detected in some samples.]

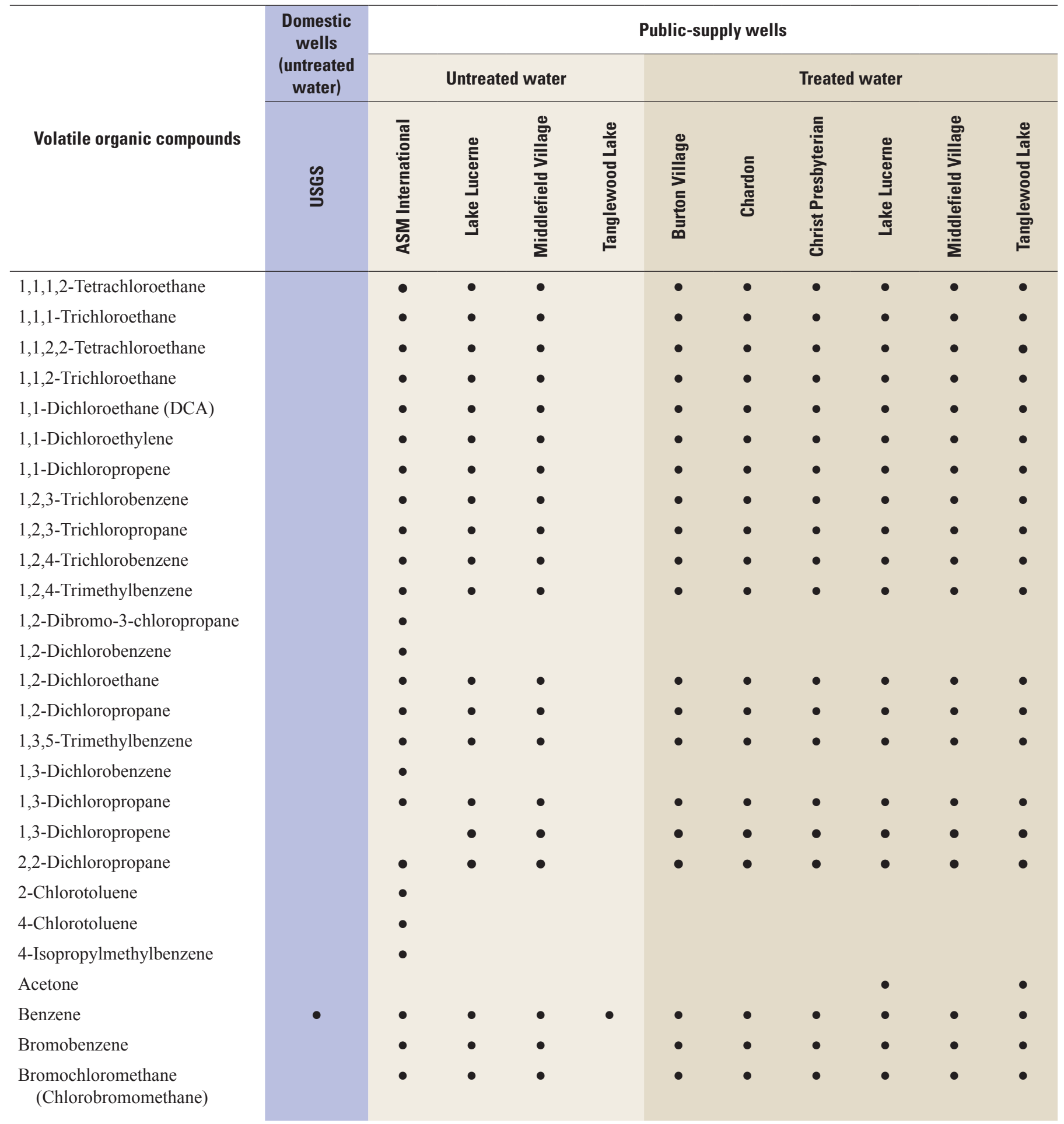


Table 4-3. Volatile organic compounds and semivolatile organic compounds analyzed for in groundwater samples in Geauga County, Ohio, 1995-2009.-Continued

[USGS, water samples from 31 domestic wells analyzed by U.S. Geological Survey personnel in 1999 (Jaguck and Darner, 2001); Public-supply well data were compiled from Ohio Environmental Protection Agency's Ambient Ground Water Monitoring Well Network program (untreated water samples from ASM International, Middlefield Village, and Tanglewood Lake) and compliance data from public-supply wells submitted to Ohio Environmental Protection Agency's Safe Drinking Water Information System database (untreated and treated water samples from Burton Village, Chardon City; Christ Presbyterian Church, Lake Lucerne Club Co., Middlefield Village; and Tanglewood Lake Water Co.). Locations of public-supply wells are shown in fig. 12; well identifiers and corresponding public-supply well names are listed in table 4 . Orange shading indicates the compound is produced as a byproduct of drinking-water chlorination; $\bullet$, analyzed for but not detected ${ }^{1} ; \boldsymbol{\Lambda}$, detected in some samples.]

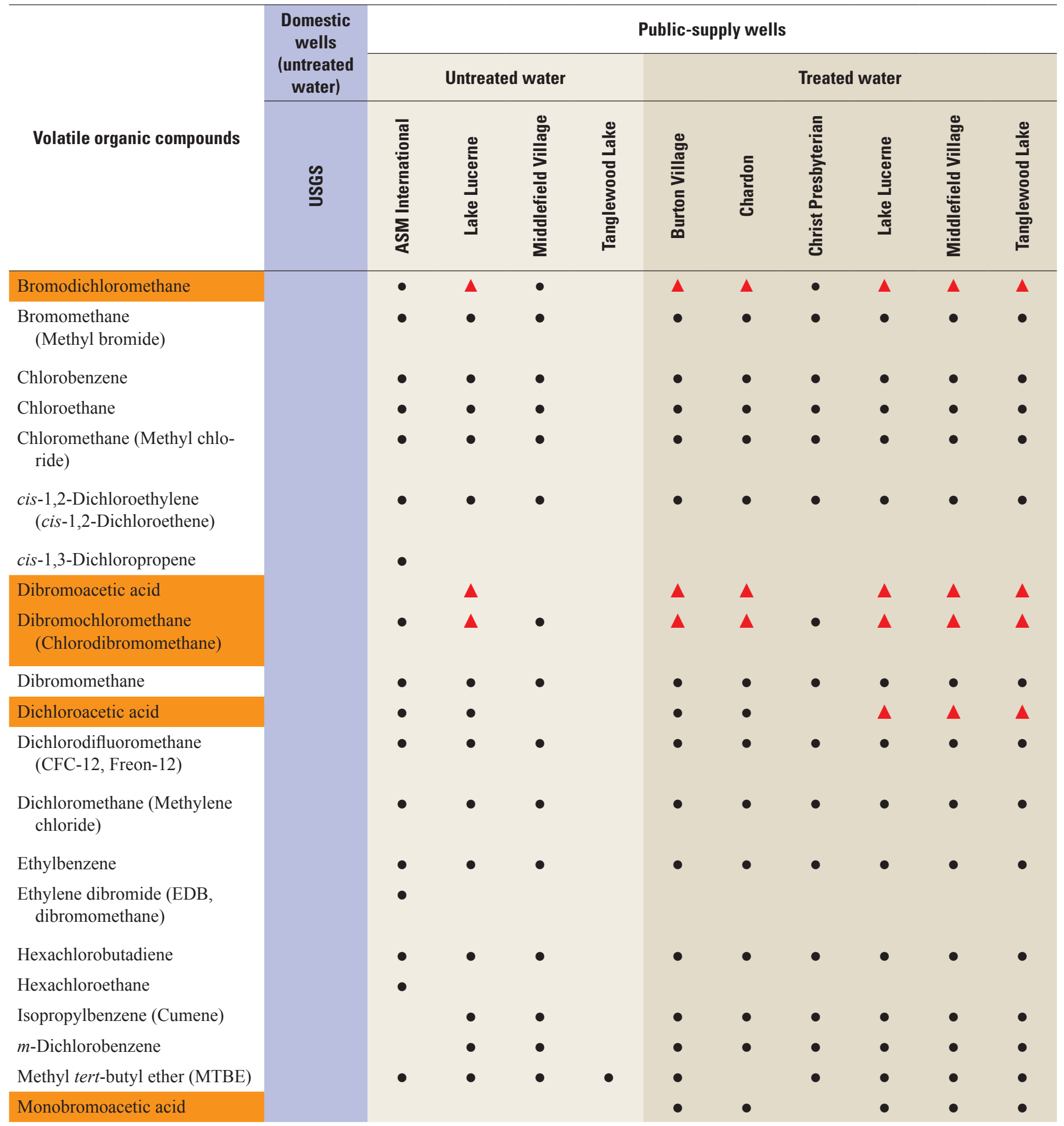


Table 4-3. Volatile organic compounds and semivolatile organic compounds analyzed for in groundwater samples in Geauga County, Ohio, 1995-2009.-Continued

[USGS, water samples from 31 domestic wells analyzed by U.S. Geological Survey personnel in 1999 (Jaguck and Darner, 2001); Public-supply well data were compiled from Ohio Environmental Protection Agency's Ambient Ground Water Monitoring Well Network program (untreated water samples from ASM International, Middlefield Village, and Tanglewood Lake) and compliance data from public-supply wells submitted to Ohio Environmental Protection Agency's Safe Drinking Water Information System database (untreated and treated water samples from Burton Village, Chardon City; Christ Presbyterian Church, Lake Lucerne Club Co., Middlefield Village; and Tanglewood Lake Water Co.). Locations of public-supply wells are shown in fig. 12; well identifiers and corresponding public-supply well names are listed in table 4. Orange shading indicates the compound is produced as a byproduct of drinking-water chlorination; $\bullet$, analyzed for but not detected ${ }^{1} ; \boldsymbol{\Lambda}$, detected in some samples.]

\begin{tabular}{|c|c|c|c|c|c|c|c|c|c|c|c|}
\hline \multirow[b]{3}{*}{ Volatile organic compounds } & \multirow{3}{*}{$\begin{array}{c}\begin{array}{c}\text { Domestic } \\
\text { wells } \\
\text { (untreated } \\
\text { water) }\end{array} \\
\\
\text { שू } \\
\text { ב }\end{array}$} & \multicolumn{10}{|c|}{ Public-supply wells } \\
\hline & & \multicolumn{4}{|c|}{ Untreated water } & \multicolumn{6}{|c|}{ Treated water } \\
\hline & & 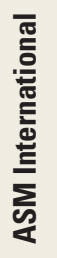 & 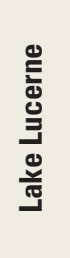 & 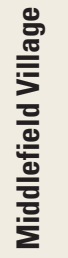 & 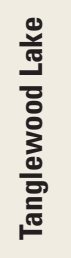 & 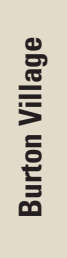 & $\begin{array}{l}\text { 흔 } \\
\frac{\pi}{\pi} \\
\frac{\pi}{4}\end{array}$ & 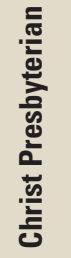 & $\begin{array}{l}\stackrel{\Xi}{\Xi} \\
\stackrel{\Xi}{\Xi} \\
\stackrel{\Xi}{\Xi} \\
\stackrel{\Xi}{\Xi}\end{array}$ & 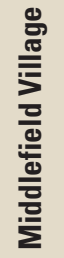 & 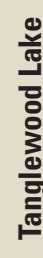 \\
\hline Monochloroacetic acid & & & $\bullet$ & & & $\bullet$ & $\bullet$ & & $\Delta$ & $\bullet$ & $\Delta$ \\
\hline$n$-Butylbenzene (Butylbenzene) & & $\bullet$ & $\bullet$ & $\bullet$ & & $\bullet$ & $\bullet$ & $\bullet$ & $\bullet$ & $\bullet$ & $\bullet$ \\
\hline$n$-Propylbenzene & & - & - & - & & - & - & - & - & - & - \\
\hline Naphthalene & & $\bullet$ & $\bullet$ & $\bullet$ & & $\bullet$ & $\bullet$ & $\bullet$ & $\bullet$ & $\bullet$ & $\bullet$ \\
\hline$o$-Chlorotoluene & & & $\bullet$ & $\bullet$ & & $\bullet$ & $\bullet$ & $\bullet$ & $\bullet$ & $\bullet$ & $\bullet$ \\
\hline$o$-Dichlorobenzene & & & $\bullet$ & $\bullet$ & & $\bullet$ & $\bullet$ & $\bullet$ & $\bullet$ & $\bullet$ & $\bullet$ \\
\hline$p$-Chlorotoluene & & & $\bullet$ & $\bullet$ & & $\bullet$ & $\bullet$ & $\bullet$ & $\bullet$ & $\bullet$ & $\bullet$ \\
\hline$p$-Dichlorobenzene & & & $\bullet$ & $\bullet$ & & $\bullet$ & $\bullet$ & $\bullet$ & $\bullet$ & $\bullet$ & $\bullet$ \\
\hline$p$-Isopropyltoluene & & & $\bullet$ & $\bullet$ & & $\bullet$ & $\bullet$ & $\bullet$ & $\bullet$ & $\bullet$ & $\bullet$ \\
\hline sec-Butylbenzene & & $\bullet$ & $\bullet$ & $\bullet$ & & $\bullet$ & $\bullet$ & $\bullet$ & $\bullet$ & $\bullet$ & $\bullet$ \\
\hline Styrene & & $\bullet$ & $\bullet$ & $\bullet$ & & $\bullet$ & $\bullet$ & $\bullet$ & $\bullet$ & $\bullet$ & $\bullet$ \\
\hline tert-Butylbenzene & & $\bullet$ & $\bullet$ & $\bullet$ & & $\bullet$ & $\bullet$ & $\bullet$ & $\bullet$ & $\bullet$ & $\bullet$ \\
\hline $\begin{array}{l}\text { Tetrachloroethylene (Tetrachlo- } \\
\text { roethene, Perchloroethylene, } \\
\text { PCE) }\end{array}$ & $\bullet$ & $\bullet$ & $\bullet$ & $\bullet$ & $\bullet$ & $\bullet$ & $\bullet$ & $\bullet$ & $\bullet$ & $\bullet$ & $\bullet$ \\
\hline $\begin{array}{l}\text { Tetrachloromethane (Carbon } \\
\text { tetrachloride, Freon 10) }\end{array}$ & & $\bullet$ & $\bullet$ & $\bullet$ & & $\bullet$ & $\bullet$ & $\bullet$ & $\bullet$ & $\bullet$ & $\bullet$ \\
\hline Toluene & $\bullet$ & $\bullet$ & $\bullet$ & $\bullet$ & $\bullet$ & $\bullet$ & $\bullet$ & $\bullet$ & $\bullet$ & $\bullet$ & $\bullet$ \\
\hline Total haloacetic acids & & & $\boldsymbol{\Delta}$ & & & $\boldsymbol{\Delta}$ & $\boldsymbol{\Delta}$ & & $\boldsymbol{\Delta}$ & $\Delta$ & $\boldsymbol{\Delta}$ \\
\hline $\begin{array}{l}\text { trans-1,2-Dichloroethene } \\
\text { (trans-1,2-Dichlroethylene) }\end{array}$ & & $\bullet$ & $\bullet$ & $\bullet$ & & $\bullet$ & $\bullet$ & $\bullet$ & $\bullet$ & $\bullet$ & $\bullet$ \\
\hline trans-1,3-Dichloropropene & & $\bullet$ & & & & $\bullet$ & & & & & \\
\hline Tribromomethane (bromoform) & & $\bullet$ & $\boldsymbol{\Delta}$ & $\bullet$ & & $\Delta$ & $\Delta$ & $\bullet$ & $\boldsymbol{\Delta}$ & $\Delta$ & $\Delta$ \\
\hline Trichloroacetic acid & & & $\bullet$ & & & $\bullet$ & $\bullet$ & & $\boldsymbol{\Delta}$ & $\Delta$ & $\Delta$ \\
\hline $\begin{array}{l}\text { Trichloroethene } \\
\text { (Trichlorethylene, TCE) }\end{array}$ & $\bullet$ & $\bullet$ & $\bullet$ & $\bullet$ & $\bullet$ & $\bullet$ & $\bullet$ & $\bullet$ & $\bullet$ & $\bullet$ & $\bullet$ \\
\hline
\end{tabular}


Table 4-3. Volatile organic compounds and semivolatile organic compounds analyzed for in groundwater samples in Geauga County, Ohio, 1995-2009.-Continued

[USGS, water samples from 31 domestic wells analyzed by U.S. Geological Survey personnel in 1999 (Jaguck and Darner, 2001); Public-supply well data were compiled from Ohio Environmental Protection Agency's Ambient Ground Water Monitoring Well Network program (untreated water samples from ASM International, Middlefield Village, and Tanglewood Lake) and compliance data from public-supply wells submitted to Ohio Environmental Protection Agency's Safe Drinking Water Information System database (untreated and treated water samples from Burton Village, Chardon City; Christ Presbyterian Church, Lake Lucerne Club Co., Middlefield Village; and Tanglewood Lake Water Co.). Locations of public-supply wells are shown in fig. 12; well identifiers and corresponding public-supply well names are listed in table 4 . Orange shading indicates the compound is produced as a byproduct of drinking-water chlorination; $\bullet$, analyzed for but not detected ${ }^{1} ; \boldsymbol{\Delta}$, detected in some samples.]

\begin{tabular}{|c|c|c|c|c|c|c|c|c|c|c|c|}
\hline \multirow[b]{3}{*}{ Volatile organic compounds } & \multirow{3}{*}{$\begin{array}{c}\begin{array}{c}\text { Domestic } \\
\text { wells } \\
\text { (untreated } \\
\text { water) }\end{array} \\
\\
\text { ळ } \\
\text { 乌 }\end{array}$} & \multicolumn{10}{|c|}{ Public-supply wells } \\
\hline & & \multicolumn{4}{|c|}{ Untreated water } & \multicolumn{6}{|c|}{ Treated water } \\
\hline & & 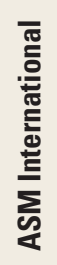 & 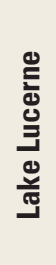 & 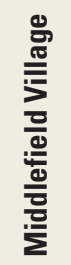 & 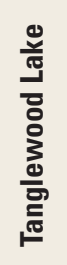 & 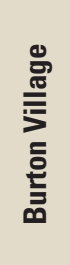 & $\begin{array}{l}\text { 흘 } \\
\text { 흔 }\end{array}$ & 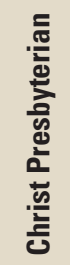 & 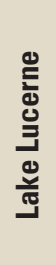 & 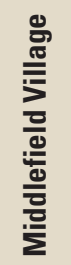 & 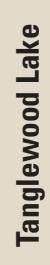 \\
\hline $\begin{array}{l}\text { Trichlorofluoromethane } \\
\text { (CFC-11) }\end{array}$ & & $\bullet$ & $\bullet$ & $\bullet$ & & $\bullet$ & $\bullet$ & $\bullet$ & $\bullet$ & $\bullet$ & $\bullet$ \\
\hline Trichloromethane (chloroform) & & $\bullet$ & $\Delta$ & $\bullet$ & & $\bullet$ & $\boldsymbol{\Delta}$ & $\bullet$ & $\boldsymbol{\Delta}$ & $\Delta$ & $\boldsymbol{\Delta}$ \\
\hline $\begin{array}{l}\text { Trihalomethanes } \\
\text { (unspecified mix) }\end{array}$ & & $\bullet$ & & & & & $\Delta$ & & & & \\
\hline Total trihalomethanes (TTHM) & & & $\boldsymbol{\Delta}$ & & & & $\boldsymbol{\Delta}$ & & $\Delta$ & $\boldsymbol{\Delta}$ & $\boldsymbol{\Delta}$ \\
\hline Vinyl chloride & & $\bullet$ & $\bullet$ & $\bullet$ & & $\bullet$ & $\bullet$ & $\bullet$ & $\bullet$ & $\bullet$ & $\bullet$ \\
\hline Xylene & $\bullet$ & & & & & & & & & & \\
\hline$o$-Xylene & & $\bullet$ & & & & & & $\bullet$ & $\bullet$ & & \\
\hline$m$-\& $p$-Xylenes & & $\bullet$ & & & & & & $\bullet$ & $\bullet$ & & $\bullet$ \\
\hline Total xylenes & & & $\bullet$ & $\bullet$ & & $\bullet$ & $\bullet$ & $\bullet$ & $\Delta$ & $\bullet$ & $\bullet$ \\
\hline \multicolumn{12}{|l|}{$\begin{array}{l}\text { Semivolatile organic } \\
\text { compounds }\end{array}$} \\
\hline 2-Chloronaphthalene & & $\bullet$ & & & & & & & & & \\
\hline 2-Chlorophenol & & $\bullet$ & & & & & & & & & \\
\hline 2-Nitrophenol & & $\bullet$ & & & & & & & & & \\
\hline 2,4-Dichlorophenol & & $\bullet$ & & & & & & & & & \\
\hline 2,4-Dimethylphenol & & $\bullet$ & & & & & & & & & \\
\hline 2,4-Dinitrophenol & & $\bullet$ & & & & & & & & & \\
\hline 2,4-Dinitrotoluene & & $\bullet$ & & & & & & & & & \\
\hline 2,6-Dinitrotoluene & & $\bullet$ & & & & & & & & & \\
\hline 2,4,6-Trichlorophenol (TCPh) & & $\bullet$ & & & & & & & & & \\
\hline 4-Bromophenyl-phenylether & & $\bullet$ & & & & & & & & & \\
\hline 4-Chloro-3-methylphenol & & $\bullet$ & & & & & & & & & \\
\hline 4-Chlorophenyl-phenylether & & $\bullet$ & & & & & & & & & \\
\hline Acenaphthene & & $\bullet$ & & & & & & & & & \\
\hline Acenaphthylene & & - & & & & & & & & & \\
\hline
\end{tabular}


Table 4-3. Volatile organic compounds and semivolatile organic compounds analyzed for in groundwater samples in Geauga County, Ohio, 1995-2009.-Continued

[USGS, water samples from 31 domestic wells analyzed by U.S. Geological Survey personnel in 1999 (Jaguck and Darner, 2001); Public-supply well data were compiled from Ohio Environmental Protection Agency's Ambient Ground Water Monitoring Well Network program (untreated water samples from ASM International, Middlefield Village, and Tanglewood Lake) and compliance data from public-supply wells submitted to Ohio Environmental Protection Agency's Safe Drinking Water Information System database (untreated and treated water samples from Burton Village, Chardon City; Christ Presbyterian Church, Lake Lucerne Club Co., Middlefield Village; and Tanglewood Lake Water Co.). Locations of public-supply wells are shown in fig. 12; well identifiers and corresponding public-supply well names are listed in table 4. Orange shading indicates the compound is produced as a byproduct of drinking-water chlorination; $\bullet$, analyzed for but not detected ${ }^{1} ; \boldsymbol{\Lambda}$, detected in some samples.]

\begin{tabular}{|c|c|c|c|c|c|c|c|c|c|c|c|}
\hline \multirow[b]{3}{*}{ Volatile organic compounds } & \multirow{3}{*}{$\begin{array}{c}\begin{array}{c}\text { Domestic } \\
\text { wells } \\
\text { (untreated } \\
\text { water) }\end{array} \\
\\
\text { 岁 }\end{array}$} & \multicolumn{10}{|c|}{ Public-supply wells } \\
\hline & & \multicolumn{4}{|c|}{ Untreated water } & \multicolumn{6}{|c|}{ Treated water } \\
\hline & & 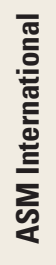 & 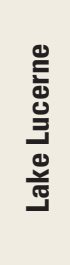 & 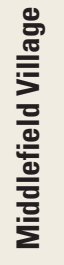 & 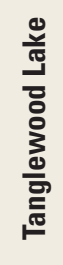 & 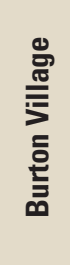 & 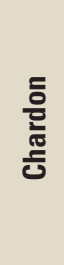 & 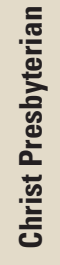 & $\begin{array}{l}\stackrel{\Xi}{\Xi} \\
\stackrel{\Xi}{\Xi} \\
\ddot{\Xi} \\
\stackrel{\Xi}{\Xi}\end{array}$ & 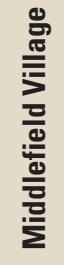 & 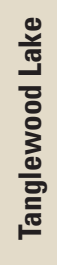 \\
\hline Anthracene & & $\bullet$ & & & & & & & & & \\
\hline Benzo $[a]$ anthracene & & - & & & & & & & & & \\
\hline Benzo $[a]$ pyrene & & - & & & & & & & - & & - \\
\hline Benzo $[b]$ fluoranthene & & - & & & & & & & & & \\
\hline Benzo $[g, h, i]$ perylene & & - & & & & & & & & & \\
\hline Benzo $[k]$ fluoranthene & & - & & & & & & & & & \\
\hline bis(2-Chloroethoxy)methane & & - & & & & & & & & & \\
\hline bis(2-Chloroethyl)ether & & - & & & & & & & & & \\
\hline bis(2-Chloroisopropyl)ether & & $\bullet$ & & & & & & & & & \\
\hline $\begin{array}{l}\text { bis(2-Ethylhexyl)phthalate } \\
\text { (DEHP) }\end{array}$ & & $\bullet$ & & & & & & & & & \\
\hline $\operatorname{bis}(n$-octyl)phthalate & & $\bullet$ & & & & & & & & & \\
\hline Butyl benzyl phthalate & & $\bullet$ & & & & & & & & & \\
\hline Chrysenes, C1-C4 & & - & & & & & & & & & \\
\hline Cymene & & $\bullet$ & & & & & & & & & \\
\hline Di(2-ethylhexyl) adipate & & & & & & & & & - & & - \\
\hline Di(2-ethylhexyl) pthalate & & & & & & & & & $\bullet$ & & $\bullet$ \\
\hline Dibenzo $[a, h]$ anthracene & & - & & & & & & & & & \\
\hline Dibutyl phthalate & & $\bullet$ & & & & & & & & & \\
\hline Diethylphthalate & & - & & & & & & & & & \\
\hline Dimethylphthalate & & $\bullet$ & & & & & & & & & \\
\hline Dinitro-o-cresol & & - & & & & & & & & & \\
\hline Flouranthenes, C1-C4 & & $\bullet$ & & & & & & & & & \\
\hline Fluorenes, C1-C3 & & $\bullet$ & & & & & & & & & \\
\hline Hexachlorobenzene & & $\bullet$ & & & & & & & & & \\
\hline Hexachlorocyclopentadiene & & $\bullet$ & & & & & & & & & \\
\hline Ideno[1,2,3-cd]pyrene & & $\bullet$ & & & & & & & & & \\
\hline Isophorone & & - & & & & & & & & & \\
\hline
\end{tabular}


Table 4-3. Volatile organic compounds and semivolatile organic compounds analyzed for in groundwater samples in Geauga County, Ohio, 1995-2009.-Continued

[USGS, water samples from 31 domestic wells analyzed by U.S. Geological Survey personnel in 1999 (Jaguck and Darner, 2001); Public-supply well data were compiled from Ohio Environmental Protection Agency's Ambient Ground Water Monitoring Well Network program (untreated water samples from ASM International, Middlefield Village, and Tanglewood Lake) and compliance data from public-supply wells submitted to Ohio Environmental Protection Agency's Safe Drinking Water Information System database (untreated and treated water samples from Burton Village, Chardon City; Christ Presbyterian Church, Lake Lucerne Club Co., Middlefield Village; and Tanglewood Lake Water Co.). Locations of public-supply wells are shown in fig. 12; well identifiers and corresponding public-supply well names are listed in table 4. Orange shading indicates the compound is produced as a byproduct of drinking-water chlorination; $\bullet$, analyzed for but not detected ${ }^{1} ; \boldsymbol{\Delta}$, detected in some samples.]

\begin{tabular}{|c|c|c|c|c|c|c|c|c|c|c|c|}
\hline \multirow[b]{3}{*}{ Volatile organic compounds } & \multirow{3}{*}{$\begin{array}{c}\begin{array}{c}\text { Domestic } \\
\text { wells } \\
\text { (untreated } \\
\text { water) }\end{array} \\
\\
\text { S } \\
\text { 马 }\end{array}$} & \multicolumn{10}{|c|}{ Public-supply wells } \\
\hline & & \multicolumn{4}{|c|}{ Untreated water } & \multicolumn{6}{|c|}{ Treated water } \\
\hline & & 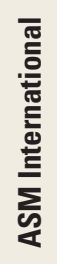 & 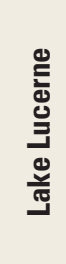 & 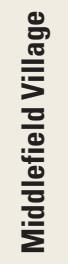 & 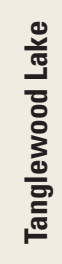 & 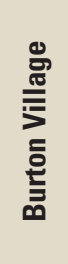 & $\begin{array}{l}\text { 흔 } \\
\text { 흔 }\end{array}$ & 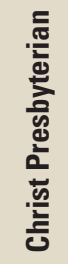 & 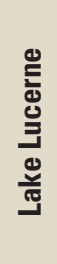 & 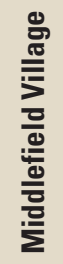 & 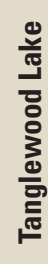 \\
\hline 4-Nitrophenol & & $\bullet$ & & & & & & & & & \\
\hline$n$-Nitrosodiphenylamine & & $\bullet$ & & & & & & & & & \\
\hline Phenanthrenes, C1-C4 & & $\bullet$ & & & & & & & & & \\
\hline Phenol (Carbolic acid) & & $\bullet$ & & & & & & & & & \\
\hline Pyrene & & $\bullet$ & & & & & & & & & \\
\hline \multicolumn{12}{|l|}{$\begin{array}{l}\text { Polychlorinated biphenyls } \\
\text { (PCBs) }\end{array}$} \\
\hline $\begin{array}{l}\text { Arochlor } 1016,1221,1232, \\
1242,1248,1254, \& 1260\end{array}$ & & & & & & & & & $\bullet$ & & \\
\hline Total PCBs & & & & & & & & & $\bullet$ & & $\bullet$ \\
\hline
\end{tabular}

${ }^{1}$ Reporting levels, where known, are as follows (reporting levels for public-supply data changed over time in some cases):

(a) USGS-analyzed domestic wells (1999): benzene, $3 \mu \mathrm{g} / \mathrm{L}$; trichloroethylene, $5 \mu \mathrm{g} / \mathrm{L}$, toluene, $3 \mu \mathrm{g} / \mathrm{L}$, PCE, $5 \mu \mathrm{g} / \mathrm{L}$, xylene, $13 \mu \mathrm{g} / \mathrm{L}$ (Jagucki and Darner, 2001).

(b) Public-supply well data: lab reporting level was generally $0.5 \mu \mathrm{g} / \mathrm{L}$, with the following exceptions: Dibromoacetic acid, dichloracetic acid, monobromoacetic acid, and trichloroacetic acid, $1 \mu \mathrm{g} / \mathrm{L}$; Methyl tert-butyl ether (MTBE) , $0.5 \mu \mathrm{g} / \mathrm{L}$ or $2 \mu \mathrm{g} / \mathrm{L}$ (rarely $5 \mu \mathrm{g} / \mathrm{L}$ ); Total halocetic acid, maximum reporting level of $6 \mu \mathrm{g} / \mathrm{L}$; p-xylene, $1.5 \mu \mathrm{g} / \mathrm{L}$; Total xylenes, 0.05 or $1.5 \mu \mathrm{g} / \mathrm{L}$; Di(2-ethylhexyl) adipate, $40 \mu \mathrm{g} / \mathrm{L}$; Di(2-ethylhexyl) pthalate, $0.6 \mu \mathrm{g} / \mathrm{L}$ or $2 \mu \mathrm{g} / \mathrm{L}$; Total trihalomethanes (TTHM), $2 \mu \mathrm{g} / \mathrm{L}$; Benzo[a]pyrene, $0.02 \mu \mathrm{g} / \mathrm{L}$; Nitro-Benzene, $0.5 \mu \mathrm{g} / \mathrm{L}, 5 \mu \mathrm{g} / \mathrm{L}$, or $10 \mu \mathrm{g} / \mathrm{L}$; Pentachlorophenol (PCP), $0.1 \mu \mathrm{g} / \mathrm{L}$; Total PCBs, $0.1 \mu \mathrm{g} / \mathrm{L}$. 


\section{Appendix 5. Oxidation-Reduction Classification of Samples}

Table 5-1. Redox environment classification for domestic wells sampled by U.S. Geological Survey in Geauga County, Ohio, 1978-2009.-Continued

[Fe, iron; $\mathrm{SO}_{4}$, sulfate; $\mathrm{O}_{2}$, oxygen; $\mathrm{NO}_{3}$, nitrate; $\mathrm{Mn}$, manganese; $\mathrm{O}_{2}$ ?, dissolved oxygen was not measured, so the presence of dissolved oxygen in groundwater and the process of oxygen reduction cannot be ruled out; $\mathrm{Fe}(\mathrm{III})-\mathrm{SO}_{4}$, iron:sulfide ratio indicates that neither iron nor sulfate reduction dominates; $\mathrm{Fe}(\mathrm{III}) / \mathrm{SO}$, sulfide was not analyzed for, so cannot distinguish between iron and sulfate reduction; Fm., Formation. If more than one redox process is listed, data were insufficient to distinguish between the two processes. The most likely process is listed first. The redox environment classification system is from Jurgens and others, 2009.]

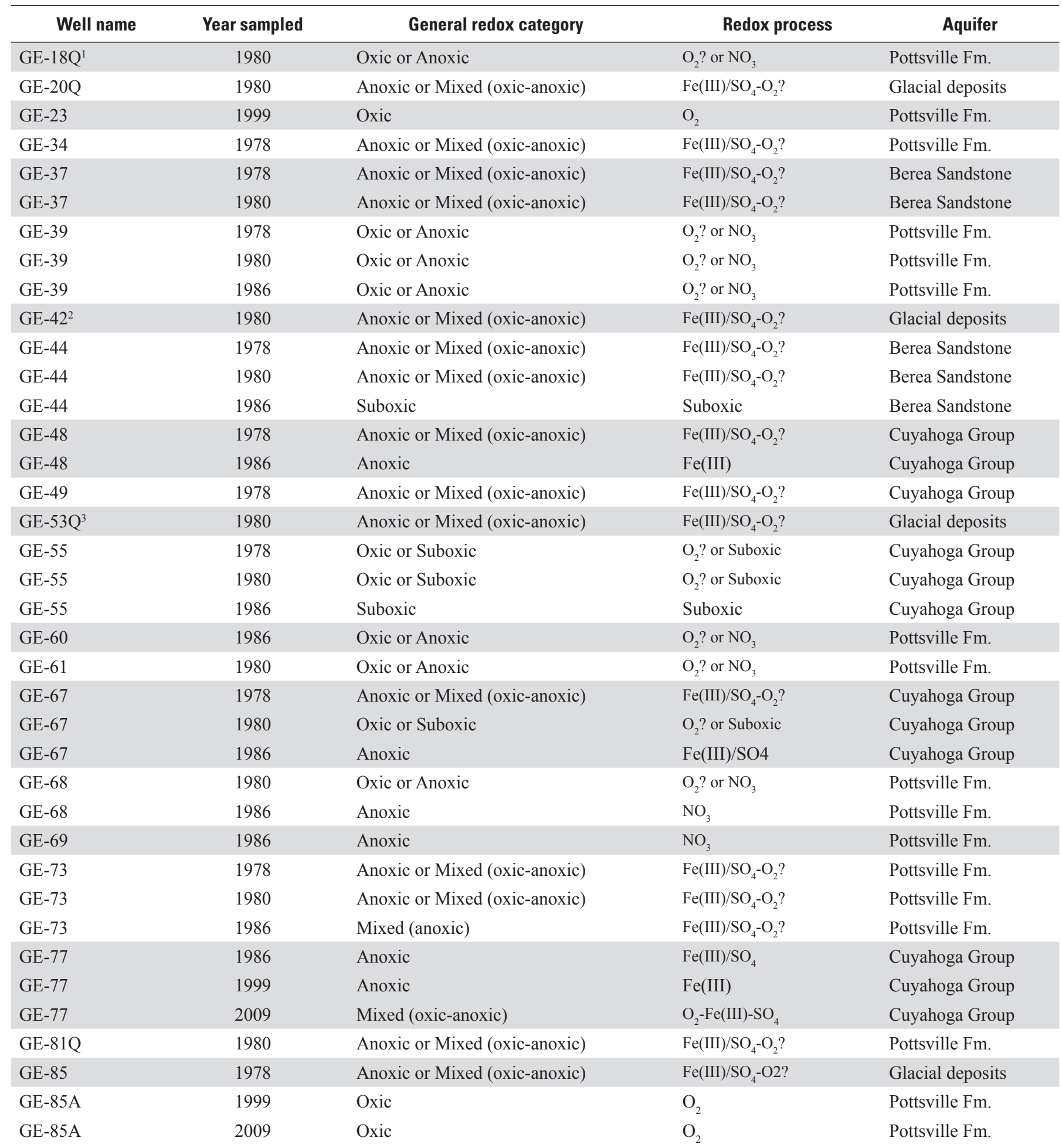


Table 5-1. Redox environment classification for domestic wells sampled by U.S. Geological Survey in Geauga County, Ohio, 1978-2009.-Continued

[Fe, iron; $\mathrm{SO}_{4}$, sulfate; $\mathrm{O}_{2}$, oxygen; $\mathrm{NO}_{3}$, nitrate; $\mathrm{Mn}$, manganese; $\mathrm{O}_{2}$ ?, dissolved oxygen was not measured, so the presence of dissolved oxygen in groundwater and the process of oxygen reduction cannot be ruled out; $\mathrm{Fe}(\mathrm{III})-\mathrm{SO}_{4}$, iron:sulfide ratio indicates that neither iron nor sulfate reduction dominates; $\mathrm{Fe}(\mathrm{III}) / \mathrm{SO}{ }_{4}$, sulfide was not analyzed for, so cannot distinguish between iron and sulfate reduction; Fm., Formation. If more than one redox process is listed, data were insufficient to distinguish between the two processes. The most likely process is listed first. The redox environment classification system is from Jurgens and others, 2009.]

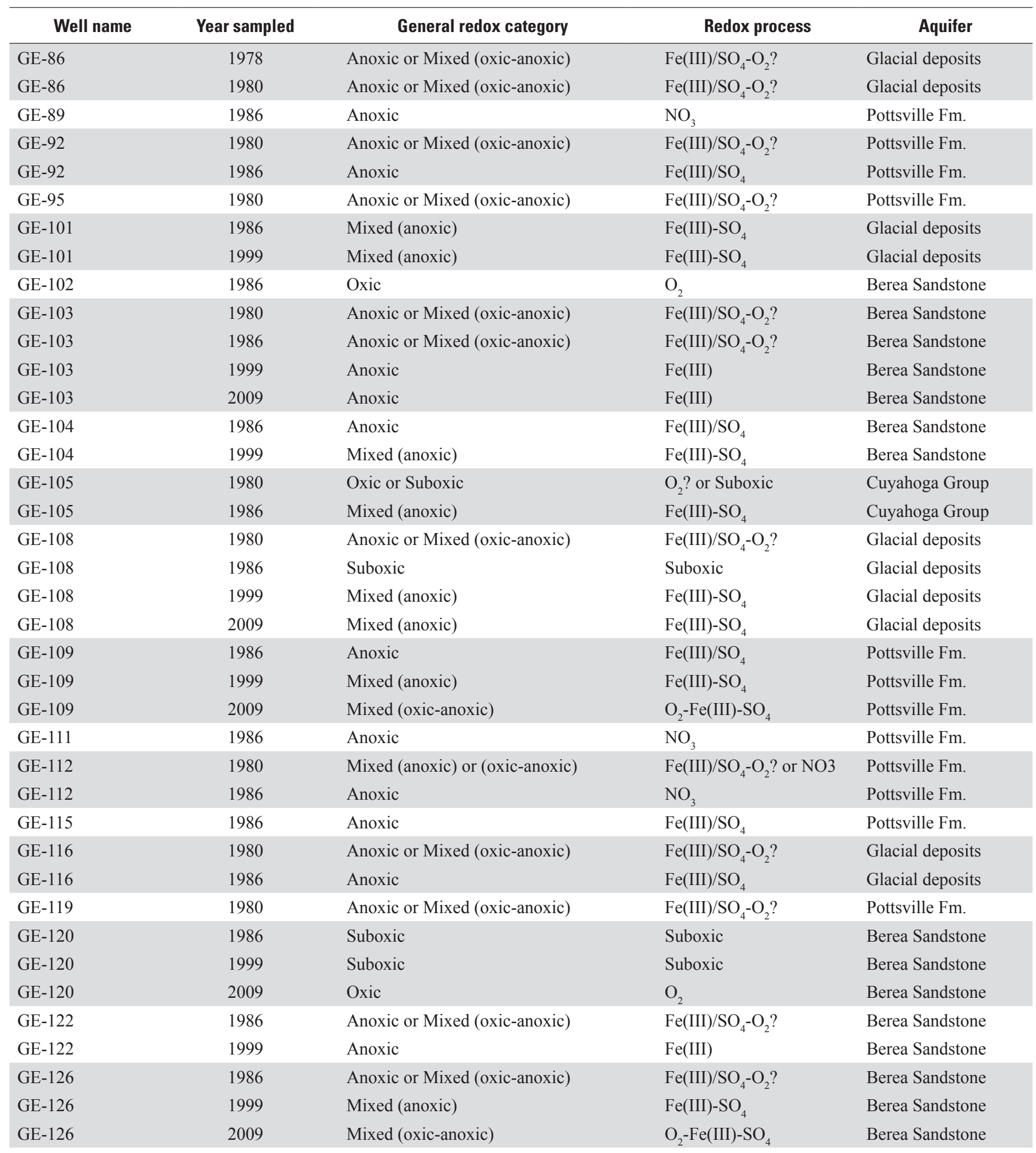


Table 5-1. Redox environment classification for domestic wells sampled by U.S. Geological Survey in Geauga County, Ohio, 1978-2009.-Continued

[Fe, iron; $\mathrm{SO}_{4}$, sulfate; $\mathrm{O}_{2}$, oxygen; $\mathrm{NO}_{3}$, nitrate; $\mathrm{Mn}$, manganese; $\mathrm{O}_{2}$ ?, dissolved oxygen was not measured, so the presence of dissolved oxygen in groundwater and the process of oxygen reduction cannot be ruled out; $\mathrm{Fe}(\mathrm{III})-\mathrm{SO}_{4}$, iron:sulfide ratio indicates that neither iron nor sulfate reduction dominates; $\mathrm{Fe}(\mathrm{III}) / \mathrm{SO}$, sulfide was not analyzed for, so cannot distinguish between iron and sulfate reduction; Fm., Formation. If more than one redox process is listed, data were insufficient to distinguish between the two processes. The most likely process is listed first. The redox environment classification system is from Jurgens and others, 2009.]

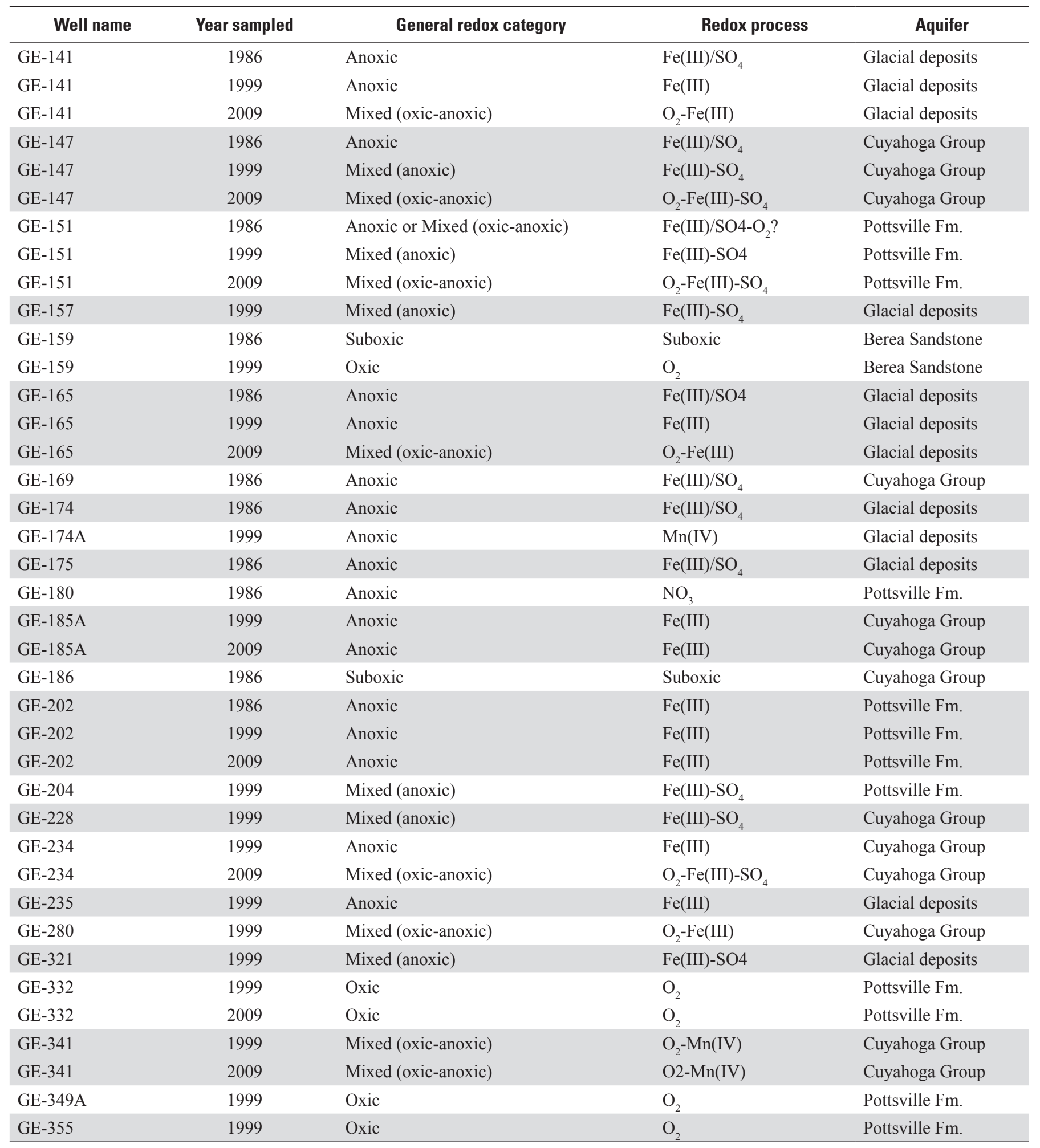

${ }^{1} \mathrm{GE}-18 \mathrm{Q}$ was a Chagrin Falls public-supply well.

${ }^{2} \mathrm{GE}-42$ was a Middlefield Village public-supply well.

${ }^{3} \mathrm{GE}-53 \mathrm{Q}$ was a City of Chardon public-supply well. 

